\title{
O MAPA GEOLÓGICO DO NORDESTE ORIENTAL DO BRASIL, Escala 1/1.000.000
}

Tese apresentada ao Concurso de Livre Docência do Departamento de Geologia Geral do Instituto de Geociências da Universidade de São Paulo no conjunto das disciplinas ligadas à Geologia Estrutural. 




\section{O MAPA GEOLÓGICO DO NORDESTE ORIENTAL DO BRASIL, Escala 1/1.000.000}

Tese apresentada ao Concurso de Livre Docência do Departamento de Geologia Geral do Instituto de Geociências da Universidade de São Paulo no conjunto das disciplinas ligadas à Geologia Estrutural.
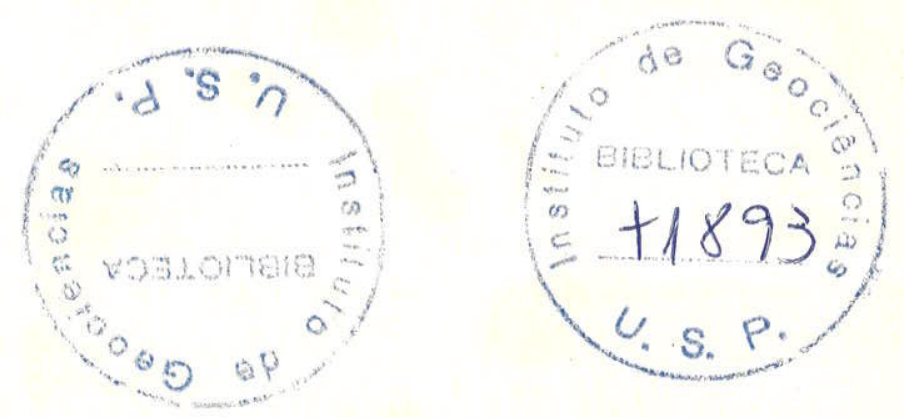
1 - INTRODUÇÃO

1.1 - APRESENTAÇÃO E OBJETIVO

1.2 - METODOLOGIA E CONCEPÇAO

2 - DOCUMEntaÇÃo CARTOGRĀFica geológica do NORdeste

2.1 - SINTESE HISTORICA

a) Fase "SUDENE" 8

b) Fase "CPRM"

c) A Contribuição do DNPM

d) A Contribuição dos Cursos de Geologia da UFPE e UFRN

e) A Contribuição da PETROBRĀS

f) Outras Contribuições

2.2 - COMENTÁRIO CRITICO

3 - ANÂlise do mAPA GeOLOGgico REgionAL

3.1 - CONCEIto E limites DA PROVÍNCiA BORBOREMA

3.2 - O NÜCLEO CRATÔNICO SINBRASILIANO

3.3 - ELEMENTOS GEOLOGICOS PRINCIPAIS DA BORBOREMA

3.3.1 - Discriminação

3.3 .2 - Zoneamento Geológico

3.4 - DUALIDADE FUNDAMENTAL DOS TIPOS LITO-ESTRUTURAIS DA REGIÃO

3.4.1 - Terrenos Metassedimentares ou Cinturões Metamórficos - Os Sistemas de Dobramentos

3.4 .2 - Terrenos gnäissico-migmatíticos(A) e mig matítico-graníticos $(M)$ 
3.5 - CONSIDERAÇOES SOBRE NOTAÇOEES ADOTADAS

3.5 .1 - Terrenos de A1to Grau

3.5 .2 - Rochas Graniticas

4 - DOMTNio Rio COREAU (I)

4.1 - O MACIÇO DE GRANJA

4.2 - O SISTEMA MEDIO COREAU

4.2.1 - A Faixa/Graben Noroeste (Martinöpole)

4.2.2 - A Faixa Sudeste ("Ubajara/Jaibaras")

A - O Grupo Ubajara (U)

B - Magmatismo

C - Grupo Jaibaras (J)

4.3 - ELEMENTOS DA GEOCRONOLOGiA

5 - O DOMINIO SERGIPANO

5.1 - A FAIXA SERGIPANA

5.1 .1 - Grupo Miabả (Pєmb)

5.1 .2 - Grupo Vaza Barris (Pعvb)

5.1 .3 - O Grupo Estância (Peest) e a Formação Palmares ( $(\varepsilon O p)$

5.1.4 - Magmatismo, Estrutura e Metamorfismo

5.2 - A ZONA INTERMEDIÁRIA

5.3 - FAIXA SUL ALAGOANA

5.3 .1 - O Complexo Macururé (Pघmc)

5.3 .2 - "Complexo Piranhas/Canindé" (Pعca,gb)

5.3 .3 - Estrutura e Metamorfismo

5.3 .4 - Magmatismo

68

5.4 - SUTMULA DOS DADOS GEOCRONOLOGICOS 
6 - DOMINIO CENTRAL (V) 71

6.1 - O SISTEMA DE DOBRAMENTOS SERIDÓ 71

6.1 .1 - Lito-estratigrafia 73

6.1 .2 - Tectônica e Metamorfismo 76

6.1 .3 - Magmatismo Granítico 77

6.1 .4 - Mineralizações (Sinopse) 79

6.2 - O SISTEMA DE DOBRAMENTOS PIANCO-ALTO BRIGIDA 79

6.2 .1 - Lito-estratigrafia 81

6.2 .2 - Tectônica e Metamorfismo 84

6.2.3 - Magmatismo Granitico 85

6.3 - O SISTEMA DE DOBRAMENTOS RIACHO DO PONTAL 87

6.3 .1 - Embasamento (Maciço Marginal ao Craton
do São Francisco)

6.3 .2 - Lito-estratigrafia e Aspectos Petrogräficos 89

6.3.3 - Compartimentação Tectônica 91

6.4 - SOTMULA DOS DADOS GEOCRONOLOGICOS 92

7 - DOMINIO JAGUARIBEANO (III) 95

7.1 - EMBASAMENTO 96

7.1 .1 - Os Maciços. 96

7.1.2 - Exposições Interfaixas 99

7.2 - OS SISTEMAS DE DOBRAMENTOS VESTIGIAIS

- As Faixas Xistosas - 100

7.2.1 - Aspectos Geolögicos Gerais 100

7.2.2 - Principais Litotipos 102

7.3 - DEPÓSITOS MOLASSOOIDES 103 
8 - DOMINIO CENTRO-ORIENTAL (IV) 105

8.1 - EMBASAMENTO 106

$\begin{array}{ll}8.1 .1 \text { - Os Maciços } & 106\end{array}$

8.1.2 - Terrenos Gnáissico-Migmatíticos do Sistema 110

8.2 - AS FAIXAS METASSEDIMENTARES 111

8.2 .1 - Tectônica e Magmatismo 112

8.3 - SUMMLA DOS DADOS GEOCRONOLOGICOS NOS DOMINIOS

$\begin{array}{ll}\text { VESTIGIAIS } & 113\end{array}$

8.3 .1 - Comportamento dos Maciços 113

8.3 .2 - Comportamento dos Sistemas 115

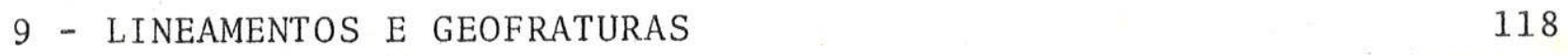

10 - A COBERTURA FANEROZÖICA 124

10.1 - ANĀLISE PRELIMINAR 124

10.2 - SEQUENCIAS SEDIMENTARES CRATÔNICAS 125

10.3 - ATIVIDADE MAGMÁTICA PÓS-SILURIANA ASSOCIADA 131

11 - AS BACIAS/PROVINCIAS SEDIMENTARES 133

11.1 - A BACIA (PROVINCIA) DO PARNAIBA OU MARANHAOO-PIAUI 133

11.1 .1 - Aspectos Geolögicos Gerais 133

11.1 .2 - Desenvolvimento Lito-estratigráfico 134

11.2 - A PROVINCIA COSTEIRA 135

11.2.1 - Bacias Tucano/Jatobä 135

A) ASPECTOS GEOLOGICOS GERAIS 135

B) DESENVOLVIMENTO LITO-ESTRATIGRÁFICO 136 
11.2.2 - Bacia Sergipe-Alagoas

A) ASPECTOS GEOLOGICOS GERAIS 139

B) DESENVOLVIMENTO LITO-ESTRATIGRĀFICO 140

11.2 .3 - Bacia Potiguar ou Apodi

142

A) ASPECTOS GEOLÖGICOS GERAIS

142

B) DESENVOLVIMENTO LITO-ESTRATIGRĀFICO 143

11.2.4 - Bacias do Saliente Oriental

A) A Sub-bacia norte

B) A "Sub-bacia" central

C) A Sub-bacia "Sul do Recife"

12 - A COBERTURA dA "PROVINCiA BORbOREMA" (s.s.)

12.1 - REMANESCENTES SEDIMENTARES PALEO-MESOZOICOS

DO INTERIOR DO NORDESTE

12.2 - DEPÓSITOS CENOZOICOS

13 - BIBLIOGRAFIA

\section{INDICE DAS ILUSTRAÇÕES FIGURAS}

Figura 1 - Esboço dos elementos geológicos principais da Provincia Borborema

Figura 2 - Domínios geológicos da Província Borborema

QUADROS

Quadro 5.1 - Esquema Lito-Estratigráfico da Faixa Sergipana

Quadro 5.2 - Esquemas Lito-Estratigráficos na Faixa Sul Ala goana

Quadro 6.1 - Colunas Lito-Estratigráficas do Sistema Seridó - Proposições Recentes

Quadro 10.1 - Sistematização das Bacias Sedimentares Fanerozöicas Nordeste Oriental do Brasil

Quadro 12.1 - "Bacias" Interiores do Nordeste: Esboço de Cor relação e Registro dos Ciclos Tecto-Sedimentares Fanerozóicos 


\section{1 - INTRODUÇAO}

\section{1 - APRESENTAÇÃO E OBJETIVO}

Este trabalho tem por objetivo precípuo descrever a geo logia do Nordeste Oriental do Brasil ao nivel da escala 1/1.000.000, em conformidade com o mapa que the é anexo.

Trata-se de um trabalho de integração, a partir de compi lação, composição e reinterpretação de värios mapas, geralmente em escalas maiores, conduzidas pelo autor nos ültimos cinco anos, de forma mais ou meı os continua e pré-estabelecida como programa de pesquisa. Verificar-se-ä que persistiu sempre certa ênfase às es truturas e associações do Prë-Cambriano, por duas razões indele veis. Primeiro, a vivência/afinidade do autor com estes tipos de terrenos ao longo de dois decênios de atividade profissional. Se gundo, porque o objetivo remoto estabelecido ao início da pesquisa fora essencialmente a Provincia Borborema, como definido por ALMEIDA et a1., 1977, que exclui grande parte das coberturas sedi mentares interiores e as bacias costeiras do Nordeste.

0 fato de preexistir um excelente mapa geolögico com no ta explicativa na escala 1/1.000.000 (e inclusive identidade de propösitos) para o Estado da Bahia explica também o plano secundā rio outorgado às estruturas do Craton de São Francisco, ao sul da Provincia Borborema.

- trabalho de pesquisa e levantamento de dados teve iní cio no segundo semestre de 1978 , tendo por meta a obtenção de uma base geológica 1/1.000.000 adequada ao "Estudo das Principais Pro víncias Metalogenëticas do Nordeste" referente ao Convênio CNPq/ /UFPE/SUDENE, Processo 77.12.265. Esta empreitada inter-departa mental da Universidade Federal de Pernambuco (Departamento de Geó logia e Engenharia de Minas) contou com a participação de väriós técnicos em suas diferentes especialidades, cabendo ao autor o en cargo da parte de cartografia geolỏgica básica desde o início. o o projeto extrapolou todas as previsões de dimensão, prazo e recur sos financeiros, chegando aos dias de hoje com lamentável faceta de obra de circulaçao restrita, e com chances de publicação muito remotas (problema de custos).

o extraordinärio fluxo de trabalhos geolögicos no Nordes 
te foi a razão de estipular a data de 1982 para o mapa geológico (dezembro de 1982), pois atë então foi feito o acompanhamento e re lação de todos os mapas publicados e a partir daí iniciada a forma final do texto explicativo, aprimorando-se värios esboços de eta pas anteriores.

A pretensão que este texto explicativo sirva de suplemen to, mais que complemento, e que o mapa seja auto-explicativo foi meta perseguida desde o início de sua organização, embora nem sem pre atingive1.

Estes mapa e texto propostos como Tese de Livre Docência junto ao Instituto de Geociências da Universidade de São Paulo, têm outras razões que a busca de titulação pelo autor. Em prime ro lugar cria a oportunidade para sua crítica e aprimoramento em meio competente, e em segundo lugar, pelo fato de circunstanciar a edição deste trabalho, que em sendo incorporado ao acervo da bi b1ioteca do IGUSP, possa ser disseminado e disposto a consulta pú blica. O estímulo do Doutor Umberto Cordani, Chefe do Departamen to de Geologia do IGUSP foi adicionalmente fator de considerävel peso.

\section{2 - MEtodologia E CONCEPÇÃO}

A composição do mapa geolögico ao milionésimo do Nordes te não seguiu ordenadamente quaisquer manual ou bibliografia espe cializada. A falta de um assessoramento contínuo foi sentida em diversas oportunidades.

A concepção geral do mapa e de sua legenda, a distribui ção espacial de seus componentes e a definição destes componentes usufruiram muito do exemplo do Mapa Geolögico do Estado da Bahia, 1/1.000.000, de INDA e BARBOSA, 1978. Neste exemp1o, o autor participou como consultor (Geotectônica e Geocronologia) e termi nou como aprendiz de cartografia geológica, persuadido que traba tho semelhante deveria ser feito para o Nordeste do Brasil. Subsi diariamente certa assessoria especializada foi colhida junto ao Setor de Cartografia do Instituto de Pesquisas Tecnológicas (IPT) de São Paulo, com profícuo resultado.

As fontes de informações, como serä discutido, foram mui 
to diversificadas em origem, localização e extensão das áreas,esca las e objetivos primärios. Muitos mapas inéditos e/ou de circula ção restrita - do autor e co-autores da SUDENE e da UFPE - foram aproveitados nesta integração ao milionésimo. Estas informações heterogêneas foram analisadas e integradas, recebendo sempre forte componente pessoal de interpretação (contatos, terminologia, estru turas) ao serem vertidas para escala ao milionésimo.

$\mathrm{Na}$ tëcnica primäria de redução dos diferentes mapas fo ram utilizadas cópias fotogräficas e xerocōpias, conforme o caso e a disponibilidade de tempo e recursos. A passagem para a base cartogräfica prë-escolhida (folhas $1 / 1.000 .000$ da Fundação IBGE) foi feita em mesa de 1uz, exclusivamente pelo autor. Nesta trans posição de escalas foram seguidas uma sërie de critërios prê-esta belecidos na seleção, uso e distribuição das informações, procuran do atingir, dentro do possível, certa coerência e uniformidade dos dados. Mas, se localmente parece acrescida a densidade de informa çõesm isto è um reflexo lógico e deliberado em função do nível e qualidade da informação naquela ärea.

Os seus dominios geológicos (e seus sub-dominios) foram nascendo gradativamente ao longo da elaboração do mapa, abstraído de preconceitos terminolögicos e geotectônicos. Esta constatação natural da região, promulgada neste mapa, corresponde ao consenso do conhecimento geolögico atual, com respaldo amplo no conjunto de caracteristicas geológicas gerais do embasamento prë-cambriano. A cobertura sedimentar não foi considerada na eleição dos domínios, haja vista que ela jä se desenvolveu herdando influência do sub trato prë-estabelecido. A discussäo objetiva com colegas da UFPE (H. BEURLEN) e da CPRM (E.J. SANTOS) foi decisiva na definição fí na1 destes domínios, cujos limites devem ser entendidos como con vencionais e temporärios, à mercê do progresso dos conhecimentos.

No quadro de relações estratigräficas a subdivisão do tempo geolögico segue em linhas gerais a do Mapa Geolögico do Bra sil 1/2.500.000, publicado em 1981 pelo DNPM, sem modificaçōes de vulto. No tocante ao Cretáceo foi adotada uma divisão dupla para a êpoca inferior ( $\mathrm{Ki}, \mathrm{Ki}$ ), mais adequada à realidade lito-crono-estratigräfica do Nordeste, como serả comentado.

Três tipos/dimensões elementares de boxes $(1,3 \times 2 \mathrm{~cm}$; $1,8 \times 1,8 \mathrm{~cm} ; 0,9 \times 0,5 \mathrm{~cm})$ foram concebidos, os quais isoladamen 
te, ou com composições, subdivisões e ornamentos de pronto discex nimento (cerca de 23 tipos e sub-tipos) procuram simbolizar os mais diversos contextos lito-estratigräficos cartografados.

A ordenação na vertical, ordenado com o tempo, entre os litossomas do mesmo dominio (ou de sub-dominios contiguos) nem sem pre pode corresponder às condições da natureza. Tirante este fato, as interrogações e indicações alternativas apostas nas diferentes colunas correspondem a deficiências e dissenções atualîssimas do conhecimento estratigräfico e geocronolögico da região, a serem abordados a posteriori.

A sinopse que apoia este quadro de relações estratigräfi cas, como complemento, procura condensar as caracteristicas decis $\underline{i}$ vas das unidades. Com ela se procura viabilizar a anälise rápida do mapa sem auxilio de nota explicativa.

As convenções geolögicas adotadas, na falta de uma fonte oficial, procuraram seguir as recomendações da SUDENE, 1966 (Sïmbo los e Normas) e de KREMER e GOMES, 1964, de franca circulação e aceitação no Nordeste. para as cores recomendadas por estes auto res foi utilizada a coleção "Multicolor Faber-Caste11-36 cores", que se mostrou adequada na elaboração.do "draft" inicial.

0 autor enfatiza, agradece e reconhece a participação im portanté das muitas contribuições recebidas e utilizadas, condição sine qua non de trabalhos de sintese desta natureza. Igualmente reconhece a discutibilidade dos méritos deste tipo de realização. Mas, acredita na necessidade imperiosa de se proceder periodica mente estes tipos de trabalhos, e de que o autor seja o destinatä rio exclusivo de todas as criticas.

\section{3 - AGRADECIMENTOS}

No decurso de um trabalho delongado desta natureza as contribuições vão surgindo e se avolumam, em fonte, tipo, número e intensidade, de forma incontrolävel. E dificil uma palavra final que traduza a sensibilidade e gratidão do autor. Ao nomear as instituições-sedes destes auxílios procura-se abranger ao maximo 
todos que nos ajudaram.

A Universidade Federal de Pernambuco, que atravës do Cen tro de Tecnologia (Dr. CARLOS DANTAS) e do Departamento de Geolo gia (Profa. LUCIA S.S. BARBOSA) pelo apoio na concessão do estágio de pós-doutoramento que possibilitou a conclusão desta tarefa. Aos colegas das discipinas Geologia de Campo, pelo proveitoso conví vio de campo, e pelos dados auferidos conjuntamente.

Ao Instituto de Geociências da U.S.P. e seu Departamen to de Geologia Geral, onde a atuação e o estimulo do Dr. Reinholt Ellert e Dr. Umberto Cordani podem simbolizar todo apoio científi co e hospitalidade recebidos em São Paulo, de todos os colegas.

A Superintendência de Desenvolvimento Científico do CNPq, que atravês de diversas "Concessões de Auxílios" e de compreensão, em värias oportunidades, constituindo o suporte inexedivel da pes quisa geolögica no Nordeste.

A CPRM - Superintendência do Recife, ao DNPM - 4 Distri to e a SUDENE-DRM, fontes mais pródigas da documentação geológica bäsica do Nordeste que se mostraram solícitas e prestativas sempre que foram abordadas pelo autor.

A Secção de Cartografia do IPT-SP pela assessoria tëcni ca indispensāvel e gratuita prestada no planejamento do mapa (Geó grafa MARIA DO CARMO SANTOS) e pelo carinho e paciência do desenho final (Técnica DAMARIS MARINS).

Ao colega Hartmut Beurlen que acompanhou, discutiu e colaborou com o autor desde as fases preliminares do projeto, da qual foi o idealizador.

Ao colega Edilton José dos Santos que com o autor redi giu recentemente um texto sobre o Nordeste para o livro de Geolo gia do Pré-Cambriano do Brasil (no pre1o), e de cujo texto muito se utilizou o autor na tarefa presente.

Ao sr. José Ponchirolli e a sra. Nair de Campos Louzada, pelos preciosos trabalhos de revisão e datilografia e a Mariza Pompeu Santos, pela coordenação bibliogräfica. Ao setor gräfico do IGUSP, equipe Jayme Alves da Silva, titulares de compe tente colaboração na edição deste texto. 
E finalmente, a minha esposa e filhos, por suportarem, (nem sempre pacientemente, é verdade) um esposo e pai que (preten siosamente) escreve textos e compõe mapas geolögicos de integra ção como objtivo de tese, ao lonto de cinco longos anos.

Nesta oportunidade são expressas também homenagem e re conhecimentos especiais a

\section{HEINZ EBERT (póstumas)}

KARL BEURLEN

A. BASKHARA RAO,

do discipulo a que deram mãos firmes e incentivo nos primeiros pas sos, o exemplo como profissionais desde então, e estímulo frate $\underline{r}$ no sempre, fatores decisivos da jornada/opção até agora percor rida. 


\section{2 - DOCUMENTACAO CARTOGRAFICA GEOLOGICA DO NORDESTE}

\section{1 - SINTESE HISTORICA}

Dentro do histörico da evolução dos conhecimentos geoló gicos do Nordeste (BRITO NEVES, 1973; BRITO NEVES, 1975), a parte de cartografia bäsica vem se situar de fato na etapa dita recente. Coube ao Professor H. EBERT, do Curso de Geologia do Recife, com seus levantamentos sucessivos na faixa do Seridó (1955 a 1970) e adjacências, o mérito de instaurar esta etapa e nela se constituir agente fecundo e referência usual. Nos seus trabalhos precursores e na orientação direta ou indireta de seus alunos, que ingressavam (a partir de 1960) nos quadros tëcnicos da Superintendência do De senvolvimento do Nordeste - SUDENE - fomentou-se uma nova e impor tante fase na histöria da geologia do nosso país.

Antes dessa ëpoca (prë-1955) as contribuiçöes à geologia regional raramente foram traduzidas em mapas. Alguns esboços geo lögicos, secções, colunas 1ito-estratigräficas, etc. são conhecí dos, com mérito inegävel para a época, mas jamais um acervo de car tografia geológica de fácil acesso, e menção obrigatória daí para nossos dias (vide CRANDALL e WILLIAMS, 1910 , como exceção).

No presente, não é fäcil discorrex sobre a documentação geolögica (cartogräfica) disponível no Nordeste, e promulgada nos ultimos 25 anos, pela sua pluralidade (em fontes e datas) e pelo risco de se expor a omissões não compreensíveis. O nümero de ma pas, em diferentes escalas e de diferentes áreas, selecionados pa ra o presente mapa ao milionêsimo não permitiu sèquer a composição de um gráfico (cartograma) de referência, recorrendo-se as referên cias nominais. Não é possível, nem faz parte do objetivo assumido, mencionar todos os mapas disponiveis no Nordeste e comenta-1os. Salvo melhor juizo, os mapas escolhidos para composição do milio nésimo aqui apresentado; correspondem àqueles mais significativos e de menção obrigatória.

$\mathrm{Na}$ anâlise desta documentação, que serä historiada por suas fontes, se verifica muitos trabalhos paralelos e recobrimen tos dificeis de se ordenar. Se muito foi feito nestes ültimos $2 \overline{5}$ anos, reconhece-se que muito mais e melhor (aprofundamento de esca 1a, solução de problemas persistentes) poderia ter sido feito com 
os mesmos recursos. A distribuição heterogênea de recursos, me diante fontes diferentes em tempos diferentes, resultou em progra mações eventuais e de prazos curtos, e muita subdivisão de esfor ços.

\section{a) Fase "SUDENE"}

A SUDENE, através de suas divisões de geologia (DGM) e hidrogeologia (HG) e de sua subsidiäria Companhia Nordestina de Sondagens e Perfurações (CONESP), liderou o setor de cartografia geológica do Nordeste, em todas as escalas, durante a década de 60.

Foram muitos os projetos específicos, com mapeamento de detalhe e semi-detalhe, voltados para äreas onde havia referên cia a bens minerais, inclusive a pesquisa e exploração de äguas subterrâneas. No campo de bens minerais, merecem menção os traba lhos voltados para a scheelita (Seridö e adjacências), ferro (São Josë do Belmonte), gipsita (Chapada do Araripe e äreas vizinhas), cobre (Médio São Francisco), chumbo e zinco (Chapada Diamantina), asbestos (Baixo São Francisco), argilas, etc., etc. No campo de hidrogeologia, a SUDENE e a CONESP foram pioneiras no Brasil em mapemanto hidrogeológico, em diversas escalas e tipos de terrenos, produzindo trabalhos clässicos na Bacia Potiguar, no Mẻdio Jagua ribe, no Alto Paraíba, no Alto Capibaribe, na Chapada Diamantina, etc. Värias séries bibliogräficas (sērie geologia regional, série geologia econômica, sêrie hidrogeologia) surgiram, sendo de con sulta acessíve1 e obrigatöria desde então.

No final dos anos 60 e início da década seguinte aparece ram os primeiros mapas de integração geolögica e hidrogeolögica regiona1, que coroaram a fase SUDENE: Os mapas do Projeto Cobre (Convênio com o DNPM, encerrado em 1964, publicado em 1970), a Geologia da Folha Serido (FERREIRA e ALBUQUERQUE, 1969), os ülti mos trabalhos de EBERT $(1969,1970)$ em Seridó e adjacências, e os mapas $1 / 500.000$ de todo o Nordeste do Inventário Hidrogeológico Bäsico.

Ainda do seio da SUDENE/Missão Geológica Alemã surgi ram trabalhos importantes de mapeamento geolögico e pesquisa mine ral, em escalas detalhes, no Vale do Curaçä-BA e no segmento nor te ocidental do sistema de dobramentos sergipanos, apresentados 
em 1973 (grande parte inëdita destes trabalhos).

\section{b) Fase "CPRM"}

O bastão da SUDENE passou gradativamente para a Compa nhia de Pesquisa de Recursos Minerais, CPRM, que a partir de 1973 (Projeto Jaibaras) ate o presente (Projeto Cachoerinha)tem coman do do mapeamento geológico sistemático do Nordeste (escala $1 / 250.000$, principalmente).

Os diversos projetos do Convênio DNPM/CPRM - Jaibaras, Fortaleza, Jaguaribe, Cococi, etc., etc. - cumprindo preceitos do Plano Mestre Decenal, conduzidos pelas agências da CPRM de Recife e Salvador, cobriram todo o Nordeste. Estes trabalhos incorpora ram praticamente todos os mapeamentos preexistentes, da SUDENE, DNPM, Escolas de Geologia, etc. e constituem um acervo notävel, ainda hoje em processo de crescimento, independente de qualquer co mentärio crítico que se queira formular. Estes mapeamentos/projetos são todos de caráter ostensivo, e apesar de um numero restrito de volumes em circulação, são hoje de pleno domínio püblico, pela sua abrangência e importância.

Ao lado destes mapas, sistemäticos e regionais, subsidio valioso de mapa milionësimo ora apresentado (e do Mapa Geológico do Brasil do DNPM, 1981 a ser discutido), a CPRM investiu em ou tras äreas, mediante recursos de pesquisa própria ou a serviço de contratantes. Ha mapas de superfície e de subsuperfície de exce lente nível compondo uma documentação importante, de áreas restrí tas, e de circulação controlada.

\section{c) A Contribuição do DNPM}

O Departamento Nacional da Produção Mineral - DNPM - ao lado de um participação efetiva atravēs de convênios (DNPM/CPRM, DNPM/Curso de Geologia, DNPM/Companhias Estaduais de Mineração, etc.), tem atuado em faixa própria, com trabalhos de mapeamento geolögico no Nordeste, esparsos no tempo.

Nas décadas de 50 e 60 devem ser mencionados os trabalhos de ALVES e MORAES (1952), KEGEL e colaboradores (1965, 1966), no mëdio e baixo São Francisco, que devem ser reconhecidos entre os 
pioneiros junto com os da SUDENE e do Curso de Geologia do Recife.

Entre estas incursões não sistemäticas devem ser salien tados os reconhecimentos fotogeolögicos de MORAES, BARROS e RAMOS (1960-1964) em diversas folhas da parte central e centro-ocidental do Nordeste, que foram aproveitados em värios outros mapeamentos posteriores (escala de reconhecimento).

No período de 1974 a 1976, o DNPM organizou e editou to dos os mapas geolögicos das folhas ao milionésimo que cobrem o Nordeste (Jaguaribe, Fortaleza, Natal, etc.), utilizando-se inclu sive de mapas produzidos pelo convênio DNPM/CPRM. Este conjunto de mapas, como trabalho de sintese e na sua escala constituem um marco na evolução do conhecimento geológico regional. o mapa geo lógico ao milionësimo ora apresentado tem neste trabalho do DNPM um paradigma, pelo seu significado em termos regionais, com o pro pósito adicional de atualização condizente.

Atualmente, atravês de convênio com o Projeto RADAMBRASIL, - DNPM volta a editar uma sêrie de mapas geolögicos ao milionés mo (não utilizados pelo autor) iniciando um ciclo que se propõe có brir todo o país. As folhas de Fortaleza, Jaguaribe-Natal e Salva dor jă estão disponíveis (edição 1980, 1981) em vārias bibliotecas.

0 mapa geolögico do Brasil 1/2.500.000, datado de 1981, editado pelo DNPM, traz uma sintese - na escala e data - de muitos méritos no gênero. Trata-se de uma fonte de consulta para muitos anos, da região e do Brasil, para pesquisadores nacionais e do ex terior.

d) A Contribuição dos Cursos de Geologia da UFPE e UFRN

Os trabalhos de mapeamentos geológicos do Curso de Geolo gia do Recife não se limitaram ao ponto de partida. Desde 1958 ja mais cessou a fonte de mapas geolögicos de detalhe, de äreas de in terêsse científico e econômico, malgrado a crônica deficiência de recursos.

Com recursos pröprios, ou mediante convênios

(SUDENE, CONESP, DNPM, Companhias Estaduais de Mineração, companhias parti culares, prefeituras municipais, CNPq, etc.), em värias áreas do Nordeste persistem trabalhos pioneiros de mapeamento geológico fe 
to por alunos (Geologia de Campo I, II, III, IV, Dissertações de Mestrado) e professores do Curso de Geologia do Recife.Uma atuação esparsa, por circunstância, mas fecunda e abnegada, como por exem plo, aqueles feitos na Bacia Costeira PE-PB-RN, na Chapada dó Araripe, nas Bacias do Médio Jaguaribe, na Bacia de Jaibaras, nas províncias scheelitífera e pegmatitífera do Seridó e do Cearä, no agreste (Carpina, Timbauba, Bezerros) pernambucano, em Condado$-\mathrm{PB}$, Salgueiro-PE, etc., etc. Estes mapas geolögicos, geralmente de detalhe, têm sido suporte substancial e via de regra absorvidos por todos os trabalhos de integração de escopo regional, apesar de sua circulação limitada (poucos nümeros) e modesta apresentação.

De idêntica forma, e no mesmo espirito, devem ser mencio nados os trabalhos de alunos e professores do Curso de Geologia de Natal. Nos ulltimos cinco anos iniciou-se uma contribuição de real ce, voltada para geologia econômica, geologia estrutural e petrolo gia, mas com incipiente cabedal de mapas geológicos de detalhe, de inestimäve1 valor.

\section{e) A Contribuição da PETROBRAS}

A contribuição da PETROBRAS no conhecimento e na carto grafia das bacias sedimentares do Nordeste tem sido importante e sem paralelo. Sejam mapas da escala de detalhe (Mapas $1 / 50.000$ da Bacia Sergipe-Alagoas, 1975, Convênio DNPM/PETROBRAS) ou mapas de integração (Bacia do Parnaíba, 1/1.000.000, Almada-Recôncavo-Tu cano-Jatobả, 1/500.000), hâ um considerável acervo formado, insub $\underline{s}$ tituível no gênero/ärea.

No tocante aos terrenos prë-cambrianos, hä incursões e mapeamentos mais raros, porëm de destaque como aqueles de RICHTER e PONTE, 1964, HUMPHREY e ALLARD, 1969, nos altos intermediārios às bacias sedimentares.

Nas bacias sedimentares do Nordeste, em geral, onde fal tou a participação da PETROBRÁs (meios e experiência) nota-se níti da retração do conhecimento geológico em geral. 


\section{f) Outras Contribuiçōes}

Como produtos diretos dos mapeamentos da SUDENE, CPRM, DNPM, etc. dantes mencionados, vārios estados nordestinos vêm edí tando (desde 1975, o Ceară) mapas geológicos estaduais, em escalas de reconhecimento. O Ceară, Bahia, Pernambuco, Paraíba jầ têm ma pas disponiveis, estando em fase de execução o Rio Grande do Norte (re-edição) e Alagoas. Isto traduz uma mentalidade nova, salutar e promissora. que adveio com o acesso de geólogos aos cargos de decisão nestas companhias estaduais.

Finalmente devem ser mencionados, ainda que seja impossí vel discriminar, os trabalhos de mapeamento geológico de detalhe concentrado no Nordeste por empresas de mineração, particulares (inumeräveis), estaduais e para-estatais (Nuclebrās, Nuclan, CPRM, etc.). Nas āreas mais promissoras de bens minerais (Seridö, Jaiba ras, Santa Quitêria, Cachoeirinha, etc.) jầ não ê mais possível um inventärio de todos os estudos e mapas, na sua grande maioria de caräter sigiloso ou de circulação extremamente restrita. Sem dūvi da, o registro é válido, e é resultado direto ou indireto que os mapeamentos geológicos dos ültimos 25 anos sementaram progresso e demanda de novos conhecimentos.

\section{2 - COMENTARIO CRITICO}

Sumariando as colaborações discutidas, o Nordeste dispõe de mapeamento geológico de toda região na escala 1/250.000 (prin cipalmente CPRM/DNPM) e inferiores (SUDENE, DNPM, DNPM/RADAMBRASIL, em preparação). Em escalas $1 / 100.000$ e $1 / 50.000$ (e superiores) a a estimativa é que cerca de $40 \%$ da região jă esteja coberta, mas con soante âreas muito espaçadas entre si (bacias sedimentares, äreas de produção mineral mais ativa ou promissora, etc.), grande diver sidade de autores, e circulação restrita dos mapas.

Na cidade do Recife, junto às bibliotecas e mapotecas do DNPM-4' Distrito, CPRM e Centro de Tecnologia da UFPE, estä concen trada a maioria deste considerävel acervo.

Não faz parte do objetivo deste trabalho, nem $\vec{e}$ da sua competência uma dissecação crítica neste acervo de documentação 
cartogräfica geolögica, consubstanciado fundamentalmente nos $\overrightarrow{1}$ timos 25 anos. Alguns problemas genëricos do presente instante do conhecimento devem ser reportados, pelo reflexo que têm na des crição e entendimento da geologia regional, especialmente quanto à lito-estratigrafia.

Em primeiro lugar, ressalta-se a qualidade não uniforme de todos os mapas, e o fato de muitos deles não se coadunarem em informações 1itológicas e estruturais - com o esperável/exigí vel pela escala que estampam. Hä uma sērie de decorrências prejü diciais deste fato, diretas e indiretas.

Tem sido prätica comum o mapeamento de feições genéricas de metamorfismo regional (xistos verdes, xistos pretos, migmatitos) em detrimento da cartografia de 1itossomas p.d., e consequen te adoção de terminologia lito-estratigräfica operacional (Cachoẹ rinha/ Cruzeta, Salgueiro/Seridö, Uauă/Caicō). Tais unidades, formuladas em escalas inadequadas, semi-detalhe e reconhecimento, ganham/ganharam rapidamente foros de unidades formais (pelo uso, pela repetição em mapas subsequentes), decididamente difícil de serem posteriormente erradicadas. Esta prätica simplista e inad vertida tem grassado com insistência, de uma ärea a outra, próxí ma ou longínqua, e com is to tem afrontado a própria compartimeñ tação paleogeogräfica/geotectônica regional, com repercussão dano sa no conhecimento estratigräfico e estrutural (adaptações e in versões têm sido constatadas).

A vinculação do aspecto litológico de campo tem estado tão arraigado às designações de mapeamento "clāssicos" que ẻ difí cil ser convincente quando se formula que nem todo migmatito (Caicó, Uauá, Caraiba), micaxisto (Seridó, Salgueiro), quartzito(Equador), etc. precisam estar relacionados no espaço e tempo com aqueles "padrões" do Seridó e do Mëdio São Francisco.

Outro tipo de problema è a prë-fixação de colunas lito-estratigräficas a tipos 1itológicos. Como por exemplo, no Seri dö (em värios trabalhos), se tentou fazer de uma unidade quartzi tica ("Equador") ou carbonätica ("Quixaba") horizonte de referên cia da coluna. As recorrências naturais de uma sequência metassé dimentar são suficientes para comprometer o mapa geológico e coluna assim edificado. 
Noutros mapas, de escala $1 / 250.000$, na temeridade (inace tāve1) de cometer erros de 1ito-estratigrafia, foram estipuladas longas colunas horizontais, não obstante as informações estrutu rais e estratigräficas clarj.videntes, na prōpria leitura do(s) ma pa(s) apresentado(s).

Estes vícios de mapeamento geolögico constituem uma heran ça pesada ao conhecimento da geologia e da lito-estratigrafia re gional. Com raras exceções, todos os termos lito-estratigräficos em uso no Prë-Cambriano do Nordeste demandam apenso (acepção de quem ? onde ?, quando ?, que escala ?), e no minimo uma redefini ção radical dentro dos requisitos bäsicos exigíveis.

Já foi comentado o paralelismo de trabalhos geológicos entre diversas entidades do governo. Hä registros de cöpias em datas diferentes de mapas geológicos en mesma escala, sem um acréscimo sequer no conhecimento. Por exemp10, o agreste meridio nal de Pernambuco está mapeado pelo menos cinco vezes em escalas $1 / 250.000$ e 1/500.000, sem modificações de vulto nas diversas edi ções. No Seridó, a repetição de mapas (com ligeiras modificações $\vec{e}$ verdade) e escalas é flagrante, enquanto os principais proble mas estruturais e estratigräficos permanecem, e com eles polêmi cas cansativas.

Estes problemas são o legado de um estāgio que não se pode evitar na trilha da maturação dos conhecimentos. Os comen tärios feitos têm cunho descritivo, abordam o consensual, e no māximo têm apelo de crítica construtiva, que reconhece a espí nhosa tarefa dos geólogos pioneiros da cartografia bäsica do Nor deste (entre os quais o autor se acha incluído), e a inevitabili dade de tais transtornos. 


\section{3 - ANALISE DO MAPA GEOLOGICO REGIONAL}

\section{1 - CONCEITO E LIMITES DA PROVINCIA BORBOREMA}

A definição original da Provincia Borborema (ALMEIDA et al., 1977, 1981) como entidade de mobilidade tectono-termal no Ciclo Brasiliano, pressupôs entre outros corolärios que:

i) Os limites da província são convencionais por definição.

ii) A província definida corresponde apenas a parte de um desenvolvimento mais extenso que tem continuida de no embasamento das províncias confinantes.

iii) A posição entre dois núcleos cratônicos sinbrasilią nos, São Francisco (ao su1) e São Luís (ao norte).

0 mapa geológico de integração apresentado focaliza a Provincia Borborema e partes das províncias que the são confinan tes, objetivando tambẻm discutir a natureza geológica destes limi tes.

O flanco leste da Província Parnaíba observävel no mapa, como serä demonstrado, mostra arranjo e estruturação na dependên cia direta do embasamento do Borborema.

Da mesma forma, em toda compartimentação da Província Costeira, no Nordeste, desde a pröpria configuração paleogeogrä́fi ca, se verifica uma componente de herança das estruturas do emba samento sotoposto, advindas da Borborema.

Estas observações preliminares com relação às províncias mais novas de coberturas são tangiveis, sem dificuldades, da ob servação direta do mapa apresentado. São limites circunstâncias, por erosão.

Com relação à Província São Francisco, mais antiga e es tảvel (Craton) no Ciclo Brasiliano, è necessärio discutir alguns aspectos de seu limite com a Borborema, tendo em vista a nitida conexão física, de campo e mapa entre seus elementos lito-estrú turais. O limite entre estas províncias acha-se relativamente bem definido apenas a sudeste do mapa, consoante o traço mais ou me nos linear (Baixo Vaza-Barris/Curaçā) que confronta a estrutura ção da Faixa Sergipana com o seu antepaís, como será detalhado 
posteriormente. Esta delimitação, já preconizada na definição das provincias foi subsidiada posteriormente por estudos geolögi cos e geofísicos conduzidos por. RAND et al., 1980.

No entanto, com relação ao limite ao sul e sudoeste, com a Província (Craton do) São Francisco, formulado em bases teọ ricas, poucos dados foram acrescentados, em nivel muito prelimi nar. Do ponto de vista estrutural há alguns registros de mudan ça de padrões de deformação de norte para o sul - ärea do Mẻdio São Francisco - obtidos em anälise de reconhecimento por SANTOS e CALDASSO, 1978 e JARDIM DE SÄ e HACKSPACHER, 1980. As deforma ções mais recentes (bra 1 ianas ?) parecem suavizar gradativamen te de norte para sul, configurando pois limite tipo transicional.

No trato das determinações Rb/Sr (BRITO NEVES, 1979) ob serva-se discernimento entre domínios de idades brasilianas (ao norte) e prë-brasilianas (ao sul) a partir do paralelo $9{ }^{\circ} 00 \mathrm{~S}$. As determinações K/Ar, em menor nümero, ratificam de certa forma a observação anterior, e mostram que a influência (termal) do Ciclo Brasiliano se estendeu até o paralelo $9^{\circ} 20^{\prime} \mathrm{S}$, pelo menos.

Esta zona de transição inter-províncias coincide em par te com um feixe de curvas gravimétricas de -50 miligals que se gue aproximadamente a fronteira Piaui-Bahia (MOTTA et al., 1979) e que delimita brusca zona de anomalias positivas situadas mais para o norte e noroeste. Ao longo desta zona, que soma estas características de transição de padrões estrutural, geocronológi co e gravimëtrico deve ser atribuído provisoriamente o limite sul da Província Borborema (como feito por DAVINO, 1980). O re exame deste problema, em caráter multidisciplinar e escala de de talhe é imprescindível para o futuro.

O Craton de São Luís (extensão brasileira do Craton do Oeste Africano) ocupa uma extensão geogräfica muito reduzida,sen do extensivamente recoberto por coberturas proterozöicas, eopaleo zóicas e fanerozóicas (principalmente) conforme ABREU et a1.,1980. De tal sorte que sobram razões para enfocâ-10 como parte do emba samento das províncias sedimentares, Parnaíba e Costeira. A ärea de exposição mais próxima da Província Borborema dista cerca duas centenas e meia de quilômetros, o que torna ousadô e contra-indi cado, no momento, qualquer análise nas relações de limites. A 
referência $\vec{e}$ feita ao Craton de São Luís, ao sul do qual se reco nhecem estruturas brasilianas (Grupo Gurupi) que podem ou não ter vínculos físicos com Qqueles do Borborema, mas não existe sub sidios para discussão deste tema nesta oportunidade. 0 maciço de Granja, possível fração marginal do Craton de São Luís seră abordado como participe do Dominio Rio Coreaủ (I).

\section{2 - O NOCLEO CRATONICO SINBRASILIANO}

$\mathrm{Na}$ fração da periferia norte do embasamento do Craton de São Francisco, destacam-se primeiramente as rochas gnäissicas e migmatiticas (A, $M)$, graníticas $\left(Y_{1}\right)$, e restos mäficos e ultra mäficos (mb, ub), e mais restritamente, quartzitos (qz). São ro chas de idade arqueana, retrabalhadas em parte no Ciclo Transama zônico, que prèdominam no embasamento da província, nos chamados "blocos" Serrinha-Uauá (a sudeste) e "Lençois" a sudoeste, con forme INDA e BARBOSA, 1978 e BRITO NEVES et a1., 1980, entre ou tros. Estas unidades, com estruturação submeridiana, adentram nitidamente e se integram ao embasamento dos sistemas de dobra mentos da Borborema, tornando dificil precisar delimitações, no conhecimento presente.

No bloco "Serrinha-Uauä" podem ser vistos esparsos rema nescentes supracrustais vulcano-sedimentares (Tui, Tfi, Tcp) de baixo grau de metamorfismo, incluindo rochas cälcio-silicäticas, filitos, metabasitos, quartzitos, etc. Estas 1itologias compõem com seu embasamento exemplos de terrenos do tipo "granito-greens tone", discutida por MASCARENHAS, 1979.

No bloco "Lençois" cabe destacar a presença de cobertu ra eoproterozöicas diversificadas metacarbonāticas, formaçōes ferriferas, xistos, quartzitos, etc., da Unidade Colomi, incIuin do uma suite de granitos e granodioritos $\left(\mathrm{Y}_{1}\right)$, vinculados ao $\mathrm{C}_{\underline{i}}$ clo Transamazônico, que serão discutidos posteriormente (item $6.3 .1)$

As demais coberturas (proterozöicas e fanerozöicas) ob serväveis na zona de lindas do Craton de São Francisco se esten dem à Província Borborema e serão objeto de anảlise no momento oportuno. 
$\vec{e}$ feito de passagem, por näo ser ela o objetivo do presente tex to.

\section{3 - ELEMENTOS GEOLOGICOS PRINCIPAIS DA BORBOREMA}

\section{3 .1 - Discriminação}

A anälise do mapa geolögico regional permite separar nó embasamento da Província Borborema dois tipos fundamentais de terrenos pré-cambrianos, de forma independente de qualquer cono tação geotectônica, e em primeiro plano:

a) Os terrenos gnäissico-migmatitíco-graniticos

b) Os terrenos metassedimentares e metavulcano-sedimen tares, ou cinturões de metamorfitos

Esta constatação geolögica primäria, fundamentada em assemblëias de litologias e padrões de deformação (1ito-estru tura1) è clarividente desde a escala de reconhecimento, ainda que o mosaico complexo formado por estes tipos de terrenos nem sempre sejam demarcados por fronteiras conspicuas. A dualidade destes tipos caracteriza a provincia.

c) Elementos estruturais de igual ordem na região em anälise são os "lineamentos" ou "geofraturas", consoante pos ção interna, externa e delimitante dos tipos de terrenos acima assinalados. São sempre marcados pela linearidade das zonas cataclásticas e miloniticas formadas, e constituem componente de importância relevante no traçado, arranjo e distribuição das linhas estruturais da província como um todo (Fig. 1).

d) As rochas magmäticas têm no Nordeste do Brasil, ex traordinäria expressividade, como destacado no mapa geolögico, especialmente no caso das litologias graniticas e afins. As feições e características destas rochas, aspecto de sua distri buição espacial e temporal serão considerados em diversas opor tunidades.

e) As coberturas presentes nesta Provincia se mostram esparsamente distribuídas, e são muito variadas em litologia, tipos estruturais e distribuição no tempo geolögico: prë-cam brianas, eopaleozöicas, paleozóicas, mesozóicas e cenozöicas. 
Apesar de rarefeitas, são marcos de eventos importantes e dis tintos da evolução geológica regional (e de províncias vizinhas), alem do que refletem muito das descontinuidades do embasamento sotoposto.

\section{3 .2 - Zoneamento Geológico}

o concerto dos elementos geológicos principais da pro vincia permite propor uma subdivisão territorial em cinco domí nios, em caräter de experiência, os quais facultam melhor apre ciação de conjunto e análise (e planejamento) do mapa geolögicó regional. Esta proposição fundamentada em bases primariamente geolögicas se mostrou posteriormente e de forma subsidiäria, im pregnada de aspectos geotectônicos, magmatogenēticos, metaloge néticos, etc.

Verifica-se um arranjo interessante e simëtrico dos do minios geológicos da região, a partir da apreciação do mapa, con densado na Fig. I e sua subsequente Fig. 2, a saber:

I-II) Dois domínios geológicos, mais externos,proximais aos nücleos cratônicos, estruturados quase diagonalmente entre si (I-NE/SW; II-NW/SE), tendo em comum a preservação de sequência metassedimentares de baixo grau, com importante contingente de rochas carbonäticas (rochas graniticas em quantidade discreta) e coberturas dobradas.

V) Uma zona central, que atravessa toda região de su doeste para nordeste (NNE-NE/SW-NNE), com predomínio de exposi ção de metamorfitos epi e mesozonais, cortados por värios tipos de rochas graniticas. Este domínio central acha-se segmentado por lineamentos em três subdomínios contíguos ( $\mathrm{Va}, \mathrm{Vb}, \mathrm{Vc}$ ).

III-IV) Dois domínios geolögicos em posição intermediā ria aos anteriormente discriminados, nos quais predominam em ex posição terrenos gnáissico-migmatíticos e migmatítico-granitícos, rochas infracrustais. Ora estes terrenos formam extensos nücleos ("maciços"), mais ou menos bem individualizados; ora estes ter renos se expõem,entre feiçōes reliquiares de metamorfitos ("sis temas vestigiais"), que compöem bandas, faixas, etc. de dimen sões modestas e distribuição esparsa. 
Coberturas náo dobrados Fonerozóicos: Províncio Costeira e Bacios interiores"

Coberturas Molássicas Cambro-Ordovioionas

VIDT Coberturos Metassedimentores do Craton e dos Maciços, Litocronocorrelatos dos Sistemas de Dobramentos mais próximos SISTEMAS DE DOBRAMENTOS MARGINAIS

(UT a) Sergipono, h) Médio Coreoú

INTERIORES

c) Riocho do Pontal

d) Piancó - Alto Brigida

e) Serido

b) Pajeú - Paraíba

f) Jaguaribeano

- VEST/GIA/S

MAGICOS GNAISSICO-MIGMATITICO-GRANITICOS

$\sim$ A-Pernambuco-Alagoos

$B$ - B'-Caldas Brandõo-S. José Campestre

C-Rio Piranhos

D- Tróio-Tauó

E-Sonta Quitério

F- Granja

G-Marginal do Croton de Sāo Francisco

Folhos Principois

050 200 $\mathrm{km}$
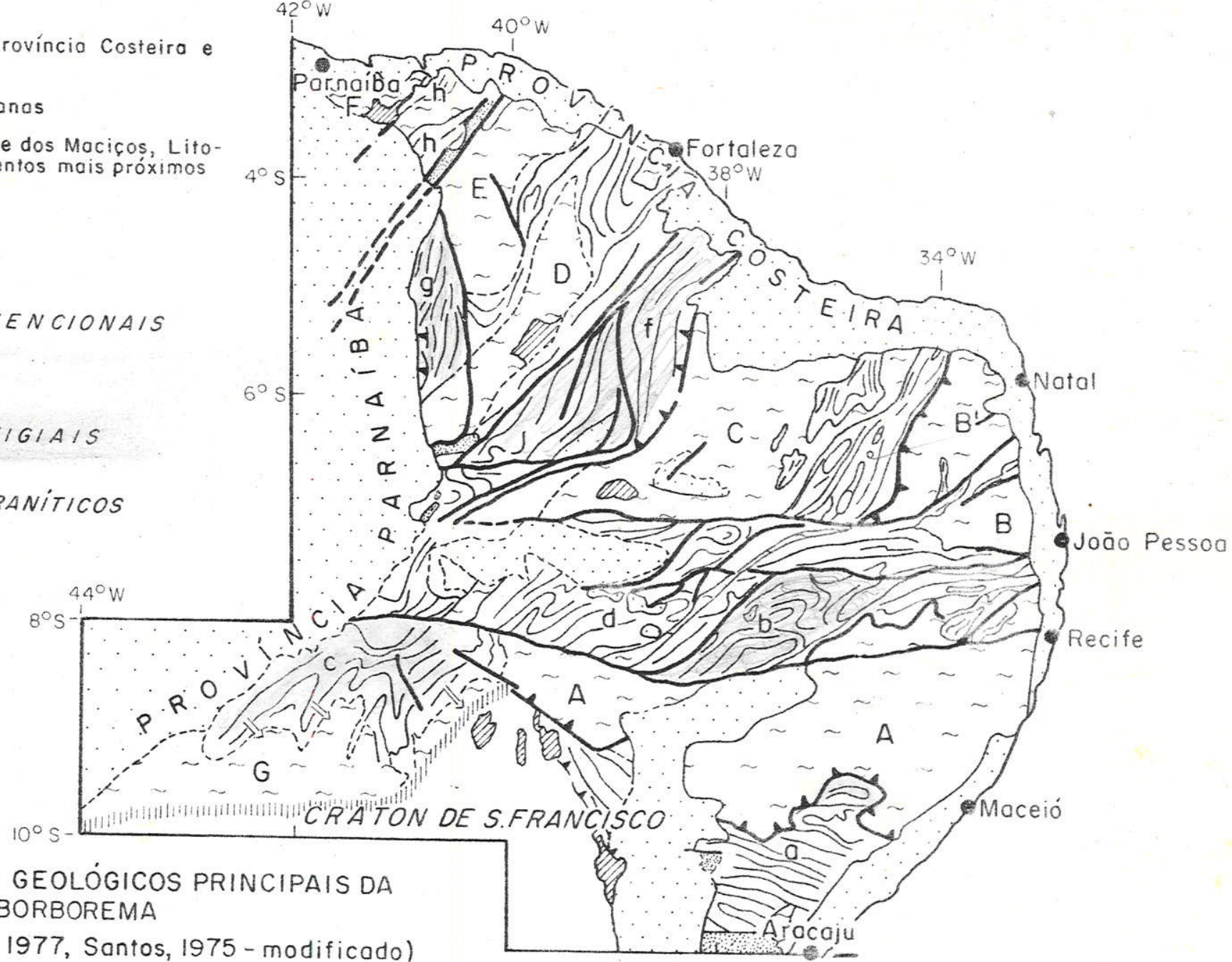


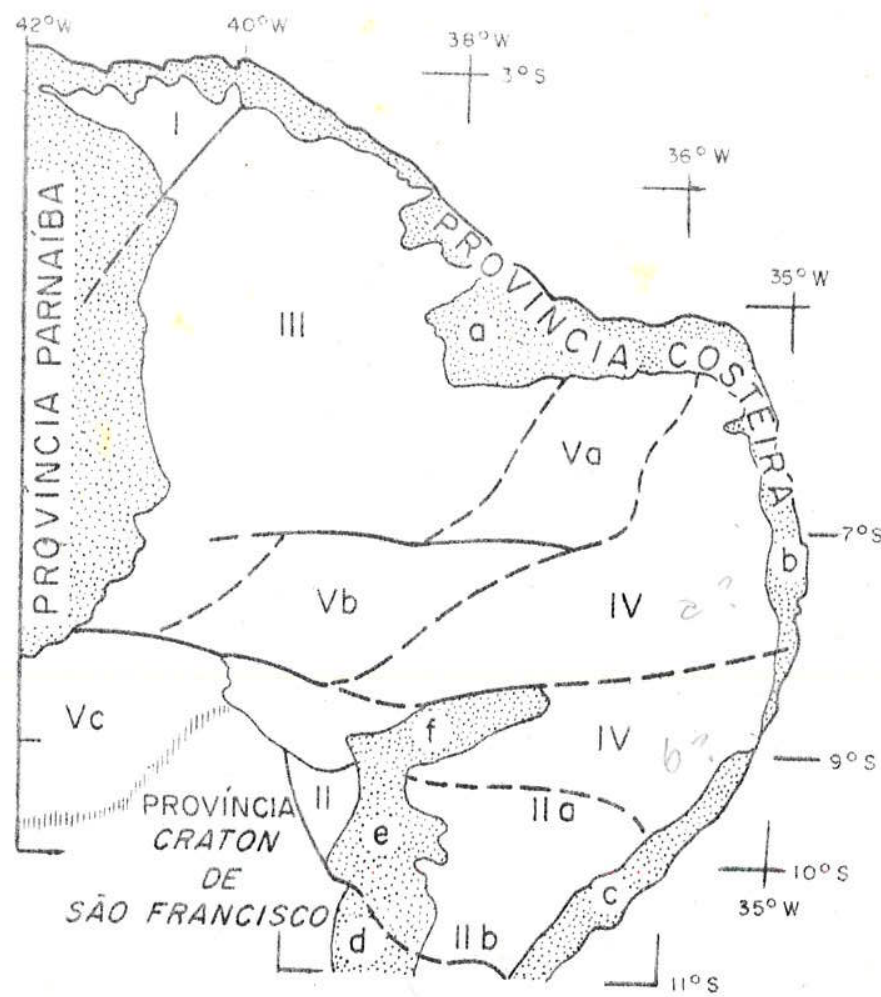

\begin{tabular}{|c|c|c|}
\hline $\begin{array}{l}\text { 1-Domínio Rio Coreoú } \\
\text { II- Domínio Sergipono } \\
\text { V- Domínio Centrol } \\
\text { Vo-Seridó } \\
\text { Vb-Pianco - Alto Brigido } \\
\text { Vc-Riocho Pontol-Rio Preto }\end{array}$ & $\begin{array}{c}\text { SISTEMAS } \\
\text { CONVENCIONAIS } \\
\text { ("OROGENIC BELTS") }\end{array}$ & $\begin{array}{l}\text { BACIAS SEDIMENTARES } \\
\text { PROVINCIA PARNAIBA } \\
\text { PROVINCIA COSTEIRA } \\
\text { a-APodi ou Potiguar } \\
\text { b- Saliente Oriental } \\
\text { c- Sergipe-Alagoos }\end{array}$ \\
\hline $\begin{array}{l}\text { III-Dominio } \\
\text { IV-Domínio }\end{array}$ & $\begin{array}{c}\text { SISTEMAS } \\
\text { VESTIGIAIS E "MACICO }\end{array}$ & $\begin{array}{l}\text { d- Tucano Sul } \\
\text { e- Tucano Centro } \\
\text { f- Jotobo }\end{array}$ \\
\hline
\end{tabular}

FIg.2- DOMINIOS GEOLÓGICOS DA PROVÍNCIA BORBOREMA 


\section{4 - DUALIDADE FUNDAMENTAL DOS TIPOS LITO-ESTRUTURAIS} DA REGIÃO

\section{4 .1 - Terrenos Metassedimentares ou Cinturões Metamörficos - Os Sistemas de Dobramentos}

Os terrenos metassedimentares e meta vulcano-sedimentares da provincia se acham distribuidos em zonas mais ou menos lineares por toda a região nordeste, alternando com os terrenos gnáissico migmatíticos. A designação informal de faixa ou sistema de dobra mentos (tradução livre de "fold belt" ou "folded belt") tem sido aplicada a estas zonas de dobramento e metamorfismo, ou partes de sua extensão total, cumprindo-se um tratamento geogräfico e geoló gico, para melhor veícular os ensaios expositivos como em BRITO NEVES, 1975 e ALMEIDA et a1., 1977.

Nos mapas na escala de reconhecimento, na anälise de cam po e na observação de imagens fotogräficas e afins, estes cintū rões de metamorfitos prontamente se destacam como tratos geológ cos distintos dos seus vizinhos, essencialmente gnäissico-migmatitícos. No estudo na escala de detalhe a separação entre estes contextos 1ito-estruturais oferece geralmente alguns problemas, e pela extensão de terrenos de um domínio a outro,e a concepção de uma passagem brusca não pode ser mentalizada.

As formas assumidas pelos sistemas de dobramento são muito variadas, ovalares, retangulares, etc., sendo geralmente alongadas consoante às direções estruturais de seus metamorfitos. Estas formas atuais são resultados finais do processo multifäsico de dissecação erosiva e de outras injunções de cunho estrutural, como os lineamentos, falhas, zonas marginais arqueadas, etc.

0 arranjo destes sistemas ê, de uma maneira geral, na am pla forma de um leque, alternando com os terrenos gnäissico-miğ matíticos, do Craton de São Francisco, ao sul, do núcleo cratôn co de São Luís, ao norte. Os sistemas mais externos da região (Sergipano, Mëdio Coreau) guardam disposição praticamente ortogo nal entre si. Os demais sistemas (ditos interiores) se distri buem desde a direção E-W atë a direção N-S, de forma que todos eles atingem a linha de costa diagonalmente. 
A posição mais externa de dois sistemas (ditos marginais) e a proximidade de núcleos cratônicos, têm implicações $\overline{1 i t o-}$ -estruturais consideräveis, suficientes para uma classificação a parte destes segmentos.

São observadas francas conexões entre os diversos siste mas, com xaras exceções, e como a histöria evolutiva è muito com plexa, torna-se dificil conjeturar-se sobre a forma e extensão do arcabouço paleogräfico dos mesmos.

As designações usuais dos sistemas (Paje $\vec{u}-$ Paraíba,Riacho Pontal-Piancó/Alto Brígida-Seridó, Jaguaribeano, etc.) devem ser figuradas na exata dimensão de compartimentos geomētrico-estruturais de referência, para facilitar a dissertação da região. E jus to, porẻm, que numa região variada e extensa como é esta, toda vez que se faz a apreciação destes compartimentos se reúna uma sé rie de características geológicas mais ou menos próprias e não transferiveis.

Os sistemas de dobramentos correspondem à äreas muito e diferencialmente trabalhadas pela erosão, e são muito acidentadas do ponto de vista geomórfico. Esta erosão diferencial forma fei xes de cristas residuais ("serras") das litologias mais resisten tes consoante o "trend" estrutural dominante. Há casos extremos de arrasa mento erosional, e de modo geral hả uma expressão topográfica mo vimentada e definida que caracteriza e pontificam estes tipos de terrenos, e suas estruturas lineares.

Uma das caracteristicas fundamentais destes tipos de ter renos, pela prōpria definição, é a assemblëia de metamorfitos pre sentes. Nos sistemas interiores hä predominio de litologias psa miticas e peliticas, com sequências variadas e mesmo semelhantes de um sistema para outro: quartzitos, micaxistos, filitos, metas siltitos, etc. com rochas calcárias e cālcio-silicatadas ocorren do de modo subordinado. A presença de metavulcânicas associadas a estes metassedimentos terrígenos tem sido crescentemente iden tificada em värios sistemas, tendo papel particularmente importan te em alguns deles.

Nos sistemas marginais, embora as sequências terrigenas estejam presentes o destaque e traço caracteristico $\vec{e}$ o contingen 
te de rochas carbonáticas, constituindo unidades 1ito-estratigräfi cas bem definidas com milhares de metros de espessura, inseridas entre outros metassedimentos terrigenos.

No seio destes estägios estratigräficos importantes, ë possivel distinguir exposições de rochas do embasamento, infra-es truturais, geralmente rochas gnäissico-migmatiticas e mesmo granu 1îticas. Estas exposições não são devido apenas a ação exclusiva erosão, mas têm causas ligadas à pröpria evolução do sistema como um todo, ou sejam, razões geodinâmicas primärias.

Neste aspecto, cabe destacar os sistemas onde existe pre servação de seus estägios estratigráficos, ou onde eles são plena mente reconstituíveis ("orogenic belts"), e as exposições do embasamento são restritas. Hä alguns sistemas onde o embasamento se expõe extensivamente, restringindo as litologias supracrustais a faixas estreitas ("schist belts") ou a localização determinada e pouco expressivas em ärea ("vestigial facets"). Nestes casos a distinção do embasamento dos estägios estruturais e estratigräficos mais inferiores se torna quase sempre uma tarefa difícil e polêmica.

Os sistemas de dobramento constituem tambëm dominios me tamörficos distintos. O metamorfismo regional predominante $\overrightarrow{\mathrm{a}}$ do tipo plurifacial, com fäcies xisto verde a anfibolito presentes praticamente em todos eles. A histöria dos eventos metamórficos e dos tipos de metamorfismo presentes são variāveis de um sistema a outro e estão em fase incipiente de entendimento.

0 metamorfismo de contato tem caráter discreto, restri tos às aurëolas dos corpos intrusivos. O metamorfismo dinâmico incide em värios sistemas, com distribuição linear e caräter sobre posto, longitudinalmente associado às zonas de geofraturas.

Outra característica saliente dos terrenos metamórficos $\vec{e}$ a linearidade impostas aos seus traços de foliação. As linhas estruturais são bem marcadas e podem ser seguidas por dezenas, cen tenas de quilômetros, segundo trajetörias retilíneas ou com algu mas deflexões, sem perder a nitidez e a continuidade (inclusive em aerofotos). 
Esta configuração proeminente ẻ resultado de uma histô ria polifäsica de deformação, em geral, atribulada pela ação das zonas de geofraturas, e cujo desenleio se processa de forma ainda lenta e embrionäria em alguns sistemas. Este estilo holomörfico apresenta alguns bons exemplos de vergência (de $\mathrm{Sn}$ ou de So) estru tural definida no sentido dos terrenos gnáissico-migmatíticos que ladeiam os cinturões metamórficos.

Como decorrência natural, das fases de evolução estrutü ral e metamörfica, os terrenos metassedimentares tambëm apresentam um comum padrão geocronológico. Uma delongada atividade geoló gica $\vec{e}$ reconhecida em todos eles, incluindo episódios deposicio nais, magmáticos, metamórficos e deformacionais, cuja reconstituí ção no tempo está em processamento ainda. No entanto, na maioria dos sistemas têm sido obtidos isócronas $\mathrm{Rb}-\mathrm{Sr}$ dentro do âmbito do Ciclo Brasiliano para o metamorfismo regional, e se têm estabeleci do várias fases de penetração de rochas ígneas e rejuvenescimento isotöpico. A etapa mais bem marcada e coerente segundo diferentes métodos radiométricos, é a de fecho deste desenvolvimento (510 $\left.450 \mathrm{~m} \cdot \mathrm{a}_{\circ}\right)$, inclusive o acesso de intrusivas fissurais, pegmatitos e resfriamento regional.

Com todas as caracteristicas acima estipuladas, a clas sificação geotectônica adequada para estes terrenos enfrenta mui tas adversidades, e alguns revezes terminológicos, pois ë precisó rever värios conceitos e escolas de conhecimento, e se envolver no conflito permanente de modelos de desenvolvimento.

As designações dentro da raiz "geossinclíneo", seja na acepção das suas fontes principais (H. STILLE, J. AUBOIN), ou seja nas acepções e adaptações posteriores dos membros das escolas "fi xista" (MURATOV, 1962; ZONENSHAYN, 1967; BUKHARIN e PYATKOV, 1973, etc.) e "mobilista" (MITCHELL e READING, 1969; DEWEY e BIRD, 1970 ; DICKINSON, 1970, etc.) esbarram sempre em obstäculos insuperāveis e um certo grau de artificialismo.

Os consensos destas escolas sobre paleogeografia, sedi mentação, magmatismo, evolução estrutural, etc., são definitivamen te de compatibilização difícil, e a designação de geossinclíneo 
corre sempre o risco inarredável de comprometimento.

O problema semântico ê crônico, uma vez que jä em 1973, W.HBUCHER (in KHAIN e SCHEINMANN, 1962) propusera o termo "mobile belt" para substituir os óbices suscitados pelo termo "geossincli neo". A expressão "mobile belt" tem sido aplicada com frequência nos ültimos anos, em especial no continente africano (ANHAEUSSER, 1969,1975 ; KRÖNER, 1972, 1976, 1977). Esta atitude foi seguida por inumeros pesquisadores brasileiros (MASCARENHAS, 1973, PEDREIRA et al., 1978; MELLO, 1979; CORDANI, U., 1978, etc.), com repercus são na Província Borborema.

Dentro desta corrente de designações, na descrição das principais feições e do desenvolvimento geológico (como em KRƠNER, $1980 \mathrm{a}, 1980 \mathrm{~b})$ dos cinturões möveis africanos são encontrados seme Thanças com os sistemas de dobramentos do Nordeste. Atë mesmo quanto à classificação (1ocalização geológica, preservação ou não da supra-estrutura) aqui jä preliminarmente esboçada.

A utilização de "mobile belt", pelo seu caräter aparente mente neutro, descritivo e de certa forma atualizado, traz algumas vantagens. Mas de forma alguma coloca um selo em todos os proble mas aqui aventados. Sempre persistem alguns aspectos em descober tos, sem paralelos, ou que não podem ser solucionados por meros exercícios de comparação baseada em bibliografia.

Ademais, os modelos geodinâmicos para evolução crustal destes cinturōes mōveis, na Äfrica como aqui e alhures, continuam como questões não respondidas, ou respondidas de forma controversa ou insatisfatöria. (colisão continental, "megashears", etc.), de mo do geral.

\subsection{2 - Terrenos gnäissico-migmatíticos (A) e migmatitíco-graníti- $\cos (\mathrm{M})$}

Os terrenos gnäissico-migmatítico-graniticos se inter põem e ramificam com os terrenos metassedimentares ao largo da Pro víncia Borborema, sendo comum se observar a extensão destes terre nos na infra-estrutura dos ierrenos metassedimentares.

Estes tipos de terrenos constituem domínios geolögicos bem distintos dos domínios vizinhos por uma série enumerável de 
caracteristicas 1itológicas, metamörficas, estruturais, geocronolō gicas, etc.

As formas dos "maciços" são muito variadas, sendo usua 1 mente poligonais, ovalares ou muito irregulares, com contornos mal delineados, não sendo raras as vezes que apresentam bordos retilí neos, subsidiados por zonas de falhamentos. As extensões territo riais variam consideravelmente na ordem de 10000 a $70000 \mathrm{~km}^{2}$.

o arranjo assumido na provincia por estes terrenos $\vec{e}$, de ordinário, uma posição intermediária aos grandes cinturões metamór ficos ou sistemas de dobramentos. Fogem desse princípio aquelas äreas gnäissico-migmatíticas que constituem a própria projeção do embasamento das áreas cratônicas sinbrasilianas mais pröximas. São eles, o Maciço de Granja ao norte, relativamente bem definido e provavelmente vinculado ao Craton de São Luís, e o maciço fron tal ao Craton do São Francisco, ao sul, que apresenta forte inter digitação lito-estrutural com o sistema de dobramentos adjacente (Riacho do Ponta1). Para esses maciços è adotada a adjetivação de "marginais" e para os demais fica preliminarmente instituída a de signação de "interiores", pelas razões expostas de mera posição geolögica.

A expressão topogräfica destes maciços, tendo em vista a sua natureza litológica mais resistente merece menção em separa do. Neles se preservam as principais frações e retalhos dos pedi planos do Planalto da Borborema, exibindo porções positivas do re levo, como nas äreas de Caruarū-Garanhuns, Campina Grande, Brejo Paraibano, Serras de Uruburetama e Itapipoca (CE), etc.

A natureza litológica destes terrenos, pela própria defi nição, ë constituỉda de extensos complexos gnäissicos, complexos migmatíticos e um variado e prolifero cortejo de rochas graniticas, lato sensu, de diferentes dimensões e de diferentes procedências. A proporção destes componentes lito-estruturais varia bastante e a aparente simplicidade deste contexto desaparece na escala de semi-detalhe.

Os complexos gnäissico-migmatitos (A) encerram grande variedade composicional, por razöes de derivação cortoderivados, 
paraderivados, tipos mistos), e de tipos estruturais, de um ponto a outro, e sempre e difícil uma separação cartogräfica dos comple xos migmatitico-graniticos $(M)$, onde as 1ineações metamōrficas são obscurecidas. Estes complexos graniticos apresentam intricada evo lução geológica (polidiapirismo, anatexia, etc.) e a extensão que alcançam em determinados maciços è preponderante, de forma que a cartografia geolögica de reconhecimento os tem tratado (às vezes) como se fossem imensos batölitos.

Ao lado desses complexos muito extensos, cabe destacar a presença de rochas graniticas, granodioríticas e sieniticas, entre outras, de dimensões mais modestas ("stocks", bossas, pequenos ba tólitos, etc.) de caräter intrusivo ou não, diques e outras mani festações igneas menores, de sorte que a afinidade com litologias graniticas è traço indelēvel na evolução geológica desses terrenos.

Corpos de rochas bäsicas e ultrabāsicas (d, gb, b, af, ub, mb, tal) em proporções mais ou menos reduzidas e descontínuas, ocorrem no seio dos complexos graniticos e migmatíticos, tendo si do geralmente dissertados como litologias reliquiares dos proces sos de granitização. Em um dos maciços (Tröia-Tauã), a presença de bäsicas e ultrabäsicas assume grandes proporções.

A presença de rochas leptiniticas, gnaisses quartzo-feldspáticos, etc., è identificada esporadicamente sempre associa das a complexos gnáissicos. A presença de supracrustais de mëdio a alto grau de metamorfismo (quartzitos, gnaisses, formações ferrí feras, xistos aluminosos, etc.), inseridas nos complexos disserta dos, tem sido ocasionalmente mapeada, com caräter exceptivo, e 10 calização restrita, guardando relações lito-estruturais diversifi cadas com os complexos acima descritos (1p, gn, qz, ca, cs, etc., no mapa).

Como estāgios estruturais-estratigräficos superiores des tes maciços ocorrem rochas de dominio metassedimentar adjacente (migmatizadas ou não), geralmente em zonas marginais dos maciços, e condicionadas por fortes e especiais injunções estruturais. Quan do estas unidades 1ito-estruturais se encontram fortemente migmat zadas, a discriminação das unidades do embasamento se torna muito dificil e comumente foco de opiniões litigantes. 
Diante dos litotipos dissertados fica explicito que pre dominam amplamente nos maciços rochas de fäcies anfibolito, e os processos de migmatização são frequentes. As ocorrências de ro chas de fäcies granulito conhecidas no Nordeste, na maioria das vê zes, tomam lugar nestes terrenos (mesmo que no embasamento dos sis temas metassedimentares).

No tocante ao padrão estrutural exibido pelos terrenos gnäissico-migmatíticos observa-se um estilo pröprio, de maior grau de complexidade que aquele observado e comentado para os dominios confinantes.

Via de regra, rarefaz-se a continuidade linear dos tra ços estruturais, sendo apenas excepcionalmente observada em poucos maciços (Granja, parte de Pernambuco-Alagoas). Em alguns desses maciços (Piranhas, Tróia, por exemp1o) o número de fases deforma cionais reconhecidas é muito grande, e segundo direções estrutü rais distintas, inclusive ortogonais entre si, e assim se obtëm um quadro eivado de interferências. Uma sërie de fechamentos e aberturas dos feixes estruturais a pequenos espaçamentos, delinea ções curvilineas e elípticas dos traços de foliação, estruturas dômicas, etc., são estilos comumente observados. Os corpos graní ticos podem se alojar circunscritos a estes esboços, como podem ser de geração tardia e acrescentar descontinuidades adicionais.

Em outros casos (Santa Quitëria, parte de Pernambuco-Ala goas) o progresso dos processos multímodos de granitização atinge proporções considerảveis da ärea do maciço, somando milhares de quilômetros quadrados, e assim desvanecem os traços estruturais pre existentes, ou são reduzidos a vestígios nebulíticos, desconexos e esporảdicos.

Do ponto de vista da geocronologia, os caracteres de evo lução policíclica são bem melhor estampados (em parte por haver um maior nümero de determinações), havendo certa coerência nos padrões de todos os maciços.

Em geral, rochas formadas em ciclos prë-transamazônicos têm sido identificados isoladamente (Caldas Brandão, Pernambuco-Alagoas) ou ocupando domínios territoriais restritos, como na 
ârea de definição dos complexos Caicó e São Vicente (Rio Piranhas). No entanto, na maioria dos casos os dados levantados deixam aberta a viabilidade de que o contingente de material crustal arqueano se ja maior, embora submetido a processos de retrabalhamento e acré ção significativos. Aliảs, muito da própria constituição 1ito-es trutural, dantes mencionada, destes terrenos é alusivel a substra tos arqueanos (WINDLEY e BRIGDWATER, 1978) por pura analogia.

O Ciclo Transamazônico foi bem mais efetivo quanto aos registros geocronolỏgicos. Os complexos gnäissicos e migmatíticos, em conjunto ou isoladamente, fornecem isöcronas $\mathrm{Rb} / \mathrm{Sr}$, de referên cia, do Transamazônico, e idades aparentes K/Ar no Brasiliano, com raras exceções.

As litologias graniticas e afins, dos extensos complexos às modestas manifestações fissurais, geralmente exibem determina ções (Rb/Sr e K/Ar) dentro do âmbito do Brasiliano (700-450 m.a.). Algumas rochas migmatiticas se comportam da mesma maneira, denun ciando formação ou reestruturação no Brasiliano.

Alguns valores de idade convencional $\mathrm{Rb} / \mathrm{Sr}$, e mesmo ida des K/Ar em rochas e minerais, em värios "maciços", se posicionam em intervalo de 900 a $1200 \mathrm{~m}$. a. Os dados são muito espalhados e pouco coerentes. Geralmente, estes dados têm sido interpretados simplisticamente como rejuvenescimento isótopico incompleto no Ci clo Brasiliano, de rochas mais antigas; mas o problema requer anä lises adicionais e deixa espaço para outras alternativas atraentes, como por exemplo, a identificação de eventos do Kibariano (Espinha ço/Uruaçuano) no Nordeste. Além do mais, a constatação do fato ratifica o caräter policíclico dos maciços, propugnado neste con texto.

Antes de discorrer sobre o enquadramento como unidades geotectônicas destes tipos de terrenos, que no cenärio regional, formam nücleos entre os sistemas de dobramentos, ë preciso ponde rar sobre alguns temas concernentes, cujo conhecimento è precärio, como seja, a exata delimitação geológica e geofísica de cada um destes "altos tectônicos", e a natureza da sua evolução paleogrä fica e estrutural, com relação aos sistemas de dobramentos adjaceñ tes. 
$\mathrm{Na}$ bibliografia euro-asiatica hả farta documentaçāo bi bliogräfica sobre estruturas assemelhadas, sua importância, e mes mo certo exagero de designações (maciços, maciços medianos, "median zones", "core areas", "zwischengebirge", etc.).

$\mathrm{Na}$ literatura corrente de Tectônica Global, incisivamen te nos principais 1 ivros-texto jä editados, faltam referências so bre presença e significado destes componentes estruturais. Raras menções têm sido observadas ultimamente na Europa (por exemplo, BARD et al., 1980) e na Africa (BERTRAND e CABY, 1978; SCHACKLETON, 1976), consoante designações neutras como "maciços", "blocos", "zo nas centrais", ou ainda, designações mais arrojadas, como "micro placas", "microcrätons", etc.

$\mathrm{Na}$ discussão dos cinturões möveis africanos, ditas sem comprometimento a escolas, e meramente descritivas, têm aparecido referências frequentes semelhantes, sob a denominação de "cratonic remnants" (ANHAEUSSER et a1., 1969), "basement inliers" (KRÖNER, 1977), entre outros.

Interessante e mencionāvel descrição de estruturas afins foi feita recentemente por WINDLEY, 1979 em caräter descritivo se guro ("Complexos granito-migmatiticos") de litologia, estrutura, histöria policíclica e comportamento geotectônico, sem apelar para classificações especializadas. Os exemplos são da Groenlândia e do Bloco Bältico, admitindo idade original eoproterozóica.

\section{5 - CONSIDERAÇOES SOBRE NOTAÇOES ADOTADAS}

\section{5 .1 - Terrenos de Alto Grau}

Deve ficar explicito desde início que a notação singela (letras $\underline{A}$ e $M$ ) para os terrenos de alto grau da província não ë feita sem reflexão, nem pretende corresponder a um retrocesso na lito-estratigrafia ("Complexo Fundamental", usado no início do sé cu1o). Mas, corresponde ao resultado de uma avaliação de vários fatos e ao atendimento de preceitos do guia de classificação, ter minologia e procedimento estratigräficos. Hầ värios pontos a pon derar:

i) E considerāvel e predominante o contingente de unida 
des lito-estruturais prê-proterozóicas no seio das unidades epigra fadas de $\underline{A}$ e $\underline{M}$.

ii) A participação de unidades lito-estratigrâficas prote rozóicas vem sendo (e serä) gradativamente apontada nominalmente em värios lugares, mesmo ainda fora do alcance de mapeamentos geoló gicos de escala de reconhecimento. Caso mais comum $\vec{e}$ o de migmati zação de complexos do proterozöico, que via de regra tem impedido sua discriminação dos complexos mais antigos.

iii) No caso dos complexos migmatítico-graniticos, o reco nhecimento de contribuição de processos de granitização policíclica é feito sempre, e estā estampado na pröpria legenda do mapa. Even tos complexos associados a granitização dos Ciclos Transamazônico e Brasiliano (inclusive homogeneização isotópica) devem ser trata dos no texto.

iv) Hä um fluxo interminävel e conflitante de termos lito-estratigräficos informais de escala de reconhecimento que não supe ram os problemas acima descritos. A decisão entre eles segue mais a compartimentação geogräfica ("Caraiba", "Uauã", "Cabrobö", "Monteiro", "Caicö", "Nordestino", "Tambori1-Santa Quitêria", "Pedra Branca", etc.) ou o prestígio da nomenclador do que critérios lito-estratigräficos concretos. No momento, não hả meios imparciais, de opção entre estes termos.

v) "Claridade de definição e tão essencial a estratigra fia como para qualquer ciência" (H. HEDBERG, 1972). No momento que estes complexos forem definidos concretamente, incluindo os requis tos minimos (estratotipos, secções de referência, extensão) de tal procedimento, eles deverão ser considerados. Pelo menos, quando for possịvel definir a extensão territorial de cada um desses comple xos.

vi) "O uso de conceitos irreais, vagos e obscuros e fre quentemente defendido porque $\bar{e}$ mais fäcil ou mais simples ou mais atrativa ou mais tradicional, mas isto não é uma modalidade de progresso. Se o termo não pode estabelecer uma definição precisa ë usualmente de valor dübio" (H. HEDBERG, 1972). As designações ano tadas (A, M) procúraram ampliar a evidência deste problema, clamando para a atenção que ele merece, ao invēs de aceitar o caminho fä cil e irreal da multiplicação de nomes. 


\subsection{2 - Rochas Graniticas}

No tocante à classificação e representação dos corpos gra níticos no mapa ao milionésimo foram encontradas muitas dificulda des, nas quais se incluem muitas que não puderam ser superadas em värias alternativas estudadas. Alguns destes problemas devem ser expostos e discutidos.

i) Os usuais critêrios de classificação genërica (READ, HUTCHINSON, BUDDINGTON, MARMO, STEPHANSON, etc.) não podem ser usa dos para todos os corpos, pela extensão e diversidade geológica re gional, pela controversia dessas classificações, pela falta de in formações suficientes.

ii) No campo, alguns corpos maiores mostram característi cas bem distintas de um nível de exposição a outro, outros mostram composição composta, de fases petrogräficas e estruturais distintas.

iii) Nem todos os corpos graníticos são suficientemente descritos nos mapas preexistentes. A discussão da petrografia a ni vel de detalhe, às vezes, leva a omissão de características genéri cas de contato. Hä alguns corpos sem nenhuma informação geolög ca $(\lambda)$.

iv) Alguns dos corpos melhor estudados, do ponto de vista petrológico e estrutural, não podem ser destacados na escala de in tegraçăo.

v) Os estudos de interrelacionamento fases graníticas/fa ses de deformação são incipientes ainda e restritos a algumas fai xas. Predominam apreciações muito genëricas de toda a região (AL MEIDA, 1967; BRITO NEVES e PESSOA, 1974; SANTOS E MELO, 1978, etc.j, de validade no escopo de reconhecimento, que têm mostrado aprimora mento gradativo.

Considerando a importância do Ciclo Brasiliano na Provín cia, a classificação adotada procurou primeiro caracterizar os grani tóides anteriores $\left(\lambda_{1}\right)$, coetâneos $\left(\lambda_{2}, \lambda_{3}\right)$ e posteriores $\left(\lambda_{4}\right)$ a este ciclo tectono-magmático.

As caracteristicas mais conhecidas (ou mais divulgadas) dos corpos graniticos, ou predominantes no campo foram fatores de decisão entre os tipos cata e mesozonais/sintectônicos- $\lambda_{2}$ - 
(BUDDINGTON, 1959; MARMO, 1971), e epizonais/tardi e pös-tectôni$\cos -\lambda_{3}$

Qualquer outro critërio de representação sugestionävel para escala de reconhecimento enfrentarā problemas desśa ordem, e dificilmente não recorrerä em adaptação e imperfeições. 0 mag matismo granitico será discutido no texto, obedecendo a distri buição dos domínios geolögicos propostos. 


\section{4 - DOMINIO RIO COREAU (I)}

Este domínio ë formulado para abranger a parte mais se tentrional do escudo Atlântico, delimitado bruscamente a leste pe lo lineamento Transbrasiliano (falha de Sobral-Café Ipueiras). In clui as rochas do sistema de dobramentos do Mëdio Coreau, e do seu embasamento, expostos ao largo de blocos (Granja, Tucunduba) do Pré-Cambriano alçados por falhamentos. As extensões do seu contex to lito-estrutural para norte (Província Costeira) e para oeste (Provincia Parnaíba) acham-se encobertas. A conexão deste domínio geológico com estruturas e litologias do Craton de São Luís e da faixa do Gurupi são esperäveis e deve ser esquadrinhada em futuro.

Apesar do brusco limite considerado a leste, hä reflexos do desenvolvimento geolögico desta ärea, em toda a borda ocidental do dominio (II) que the é confinante, principalmente com referência a presença de rochas ígneas intrusivas (granitos pós-tectônicos).

\section{1 - O. MACIÇO DE GRANJA}

O maciço ou "Bloco" de Granja situa-se entre o delta do Parnaíba (Piauí) e Jeriquaquara, no 1itoral cearense, com ärea de afloramentos reduzida, face aos vários tipos de coberturas pre sentes, o que impede aquilatar suas reais dimensões.

O maciço de Granja e o Craton de São Luís guardam värias analogias de ordem lito-estrutural (HURLEY et a1., 1967; ALMEIDA, 1965; BRITO NEVES, 1973) alëm de se alinharem segundo um mesmo e importante alto estrutural o "Arco Ferrer - Urbano Santos - Guamá", cuja reativação teve maior ênfase no Cretāceo. Embora a ärea en tre o Craton de São Luís e o maciço de Granja seja pouco conhecida e bastante recoberta (Bacia de Barreirinhas), o segundo ë proposto como projeção do embasamento do primeiro, ainda que numa extensão parcialmente regenerada.

Uma tentativa de equiparação das litologias encontradas no maciço de Granja e aquelas dissertadas no Craton de São Luís (Complexo Maracaçumê de ABREU et al., 1980) è em parte bastante atraente. Mas, a distância entre as äreas relativamente bem conhe cidas (em torno de $450 \mathrm{~km}$ ) desaconselha qualquer iniciativa.

A presença de sullcos externos sobrepostos, fossas molas 
sicas e intensa tectōnica rutural, etc. são fatores que conferem à borda sul deste maciço caracteristicas de autêntico sistema tẹ tônico marginal de plataforma.

Predominam na constituição do maciço de Granja rochas gra nulares escuras, deformadas, com composição modal de tonalítica até dioritica, com ocorrências de värios outros tipos subordinados, e en grande parte desenvolvendo diversas estruturas migmatiticas (A) São rochas essencialmente ricas em plagiocläsios, os quais exibem evidência de crescimento, portanto considerävel nümero de inclusões, e quase sempre com textura mortar na periferia de seus fenoblastos. 0 quartzo e o feldspato potässico têm sempre uma participação secundāria na formação destas rochas, nas quais horn blenda e biotita são mäficos típicos e frequentes. E possível que grande parte destas rochas seja ortoderivada.

Intercalam-se neste contexto rochas de caräter metasse dimentar e elevado grau de metamorfismo, como gnaisses leptiníti cos, gnaisses kinzigíticos, piroxênio-gnaisses e ainda bandas es treitas de quartzitos feldspäticos e quartzitos ferríferos,bastan te cisalhados $(q z)$.

A oeste de Granja, toda porção sul ocidental da ärea de exposição do maciço é dominada por uma rocha granítica porfirîti ca (M), o chamado "granitöide de Chaval", típico pelos fenoblas tos centimétricos de feldspato potässico zonado; são comuns fäcies sieniticas, a orientação incipiente, e vestígios de evolução mig matítica.

Todo o contexto de rochas migmatiticas e gnäissicas acha-se fortemente orientado na direção geral do maciço, com mono tona lineação NE-SW,e mergulho da gnaissificação muito forte para sudeste. Värias falhas de direção NE-SW são encontradas no inte rior do maciço, propiciando contínuas e paralelas zonas de ciza lhamento. São falhas paralelas àquelas do sistema de dobramento
adjacente. 


\section{2 - O SISTEMA MẼDIO COREAU}

A designação supra procura enfeixar de melhor forma a ärea a noroeste do Cearä, contigua a noroeste do chamado Lineamen to de Sobra1 - Pedro II. Trata-se de uma ärea sede de grande mo bilidade rutural ao longo do final do Prê-Cambriano, com tendên cia geral a processos de subsidência, pelo que se destacou das äreas adjacentes e foi capaz de preservar, de melhor maneira, os registros lito-estratigräficos de sua evolução, principalmente de sua supra-estrutura.

A ärea considerada tem uma forma aproximadamente retan gular, delineada pelas importantes geossuturas de direção NE-SW que a delimitam (Sobral - Pedro II e Jaguarapi), com largura mé dia da ordem de $75 \mathrm{~km}$, e extensão desconhecida sob as coberturas paleozóica (a sul) e cenozöica (a nordeste) que recobrem suas ex tremidades. A ärea de exposição é na ordem máxima de $10000 \mathrm{~km}^{2}$.

o sistema acha-se delimitado por importantes falhamen tos e mostra uma subdivisão natural em duas faixas distintas, uma a noroeste ("Martinoppole") e outra a sudoeste ("Bambui-Jaibaras"), separadas por um alto tectônico central - "o horst de Tucunduba" - onde se expõe extensivamente o embasamento. Na margem noroeste do sistema fica o maciço de Granja, e a sudeste localiza-se o Maciço de Santa Quitëria, ambos com limites bruscos e bem definidos com o sistema, alëm de uma evolução 1ito-estrutural mais antiga e distinta. Ao sul do maciço de Granja (a norte de Viçosa do Cearä) verifica-se certa extensão e sobreposição dos metassedimentos (qz) do sistema de dobramentos.

A vocação a subsidência desse sistema, contrapôs-se ao longo do Fanerozóico à tendência ascencional das ärea limítrofes. Um dos principais eixos de sedimentação da Bacia do Parnaíba se dispõe ao longo deste sistema (eixo Araticü-Tianguă, AGUIAR,1971).

Esta ärea dispõe de mapeamento geológico em escalas $1 / 100.000$ e $1 / 50.000$ (e mesmo escalas superiores, localmente), privilégio que não a tornou indene a muitos problemas geológicos. o grau de conhecimento è bom, mas hä värios problemas pendentes.

os trabalhos anteriores, mais importantes e significa 
tivos neste sistema, de KEGEL e colaboradores (1953, 1956, 1958); COBRA, 1963; WINGE, 1967; MABESOONE et a1., 1971, e värios outros estão devidamente computados e considerados nos mapeamentos execu tados a partir dos anos 70 . Outros trabalhos de pesquisa, de com panhias de mineração, de Universidades (Rio de Janeiro, Brasília, Pernambuco, Rio Grande do Norte), etc., ao nível de detalhe são igualmente disponíveis, e de ötima qualificação.

O embasamento do sistema se expõe no Maciço de Granja e ao longo do "horst de Tucunduba", com as lineações adaptadas em geral à direção NE-SW, mas envolvendo muitos dobramentos de folia ção e padrões de interferência, entre bem marcadas zonas de ciza thamento. Predominam rochas migmatiticas de estruturas as mais va riadas e gnaisses a biotita, hornblenda, epidoto e piroxênio (A). As rochas do complexo gnäissico-migmatitico se destacam pelas feições morfológicas aplainadas, salvo nas rochas quartzíticas.

Os quartzitos ( $q z$ ) se apresentam em bandas estreitas e largas, com contatos transicionais com os gnaisses e migmatitos, e suportam as feições morfológicas de destaque na ärea, as serras de Gurgueia, Saco, Jordão, Dom Simão, etc. Ocasionalmente, len

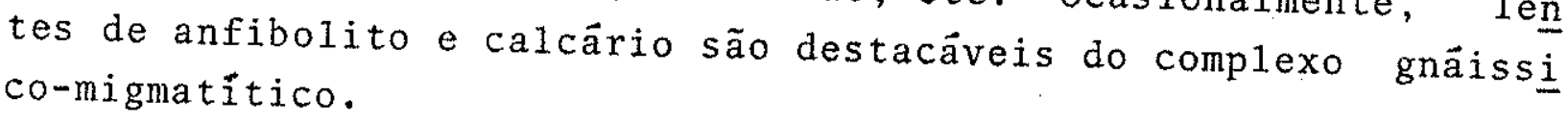

Os cataclasitos perlongam as zonas de falhas, principal mente de rejeito direcional dextrögiro, de direção geral próxima a NE-SW, em paralelo com o lineamento de Sobral.

Este embasamento $\vec{e}$ atribuido ao Arqueano (NOVAIS et al., 1979), havendo registros radiometricos de seu retrabalhamento no Transamazônico, e indiretamente no Brasiliano, configurando uma história de policiclismo.

A sudeste do açude de Tucunduba, aparece um "stock" sie nítico (si), cortando as rochas deste complexo e impingindo-1hes metamorfismo de contato. Trata-se de uma rocha mesocrätica, tex tura grosseira a porfiritica, cor cinza-esverdeada, que se mostra afetada pela mecânica tardia de cisalhamento regional. o sienito de Tucunduba é atribuído ao Brasiliano (PRADo et a1., 1979), embo ra so se disponha de idades aparentes em rocha total $\left(424 \pm 6 \mathrm{~m} . \mathrm{a}^{\circ}\right)$ referentes a este ciclo. 


\section{2 .1 - A Faixa/Graben Noroeste (Martinöpole)}

Ainda esta muito longe o consenso em torno do arranjo 1 ito-estratigräfico da faixa de Martinöpole ("graben de Martinöpo le"), embora seja pronto identificado a noção comum de um complexo e diversificado desenvolvimento metassedimentar e metavulcânico.

As dissenções entre e os problemas de cada dos esquemas 1ito-estratigräficos propostos informalmente são de tal ordem que não é possível qualquer discussão sobre a correlação das unidades cartografadas em escala de 1/50.000. Salvo quanto às unidades ba sais (Formação São Joaquim, prö-parte Formação Covão) dessa comple xa evolução, qualquer debate adicional seria inöcuo.

De fato, a qualidade precäria dos afloramentos neste "graben", por problemas de intemperismo e cobertura, o estágio uni forme de transformação termodinâmica, a intensa e delongada tectô nica rutural, sobrepondo-se sempre às fases de deformação plästica, etc., são fatores de peso, que tornam a interpretação lito-estrat gräfica do conjunto uma tarefa extremamente dificil e os esquemas propostos atê o presente têm caräter altamente especulativo, mesmo se contando com mapeamento em escala de detalhe, informações valio sas de sondagens, etc., de forma que qualquer avaliação (em separa do ou mediante confronto) agora $\vec{e}$ precipitada.

A unidade quartzítica basal (Formação são Joaquim) e composta de quartzitos a muscovita, granada e quartzitos a silli manita. Intercalam-se algumas lentes de xisto micäceo granadífero, com presença de texturas porfiroblästicas. Estes quartzitos pro gradam à margem sul do Maciço de Granja, segundo um estilo de dó bramentos vergente para noroeste (a norte de Viçosa).

Uma unidade de xistos e quartzitos (Formação Covão), ocorre sobrejacente a unidade anterior. São xistos, muscovita, biotita, granada e cālcio-xistos, com intercalações de níveis quart ziticos puros e quartzitos a muscovita, granada e sillimanita.

Pelo menos dois eventos principais de deformação plästi ca podem ser observados nestas rochas, aos quais se sobrepuseram eventos ruturais importantes. Embora falte um melhor controle, o metamorfismo regional $\vec{e}$ de fácies anfibolito e, portanto, discre pante das unidades sobrepostas. 
As unidades sobrejacentes reunem espessa e diversificada sequência de rochas sedimentares clästicas, pelíticas e psamíti cas, químicas, vulcano-clästicas e vulcânicas. Esta intricada as sociação se desenvolveu ao longo de amplo intervalo de tempo, com perdurante regime de instabilidade tectônica, comandado pelo acio namento de falhas internas e externas à faixa/"graben" de Ma tinópole.

As subdivisões dessa ampla e complexa unidade vulcano- sedimentar obtidas atē o presente têm caräter meramente operacio nal, para-estratigräfico de fato. São muitas as interdigitações látero-verticais e tambëm muitos os problemas de relacionamento estratigräfico a equacionar, e assim uma coluna estratigräfica con fiảvel não pode ser ainda elaborada. A designação de Grupo Martị nópole (Pєm) é adotada em caräter informal e abrangente, aguardan do investigações lito-estratigräficas futuras.

Existem poucos horizontes guias, pois a transformação termodinâmica foi a um grau muito homogêneo. As formaçōes ferrí chaves em potencial para utilização em futuro, enquanto se aguar da o amadurecimento gradativo do trato com os diferentes 1itosso mas individualizados, e de um melhor conhecimento da organização estrutural dos mesmos. Os trabalhos de pesquisa mineral (mapea mento de alto detalhe, sondagens, etc.) em andamento, muitas $1 \underline{u}$ zes poderão trazer ao atual contexto de problemas.

Trata-se de uma complexa associação de rochas ardosia nas e filiticas de natureza carbonática, síltica, hematítica, tü fảcea, etc., com intercalações e interdigitações com rochas meta vulcânicas ācidas e intermediārias e piroclästicas. Subordinada mente aparecem níveis, lentes e camadas de "chert", calcärios, dolomitos e, mais raramente, psamitos.

O metamorfismo regional ë na fácies xisto verde, de in tensidade baixa a moderada, sendo minerais típicos sericita e clo rita e, mais raramente, biotita (PRADO et al., 1974); as condí ções de pressão foram de baixa a mëdia e a temperatura foi o fa
tor prepoderante.

Metamorfismo cataclāstico se sobrepōe seguinte às prin 
cipais suturas regionais e principalmente ganha expressão notāvel adjacente à zona de cizalhamento de Jaguarapi, que delimita a fai xa/graben, ao norte.

O arranjo estrutural destes metassedimentos $\vec{e}$ igualmen te complexo, de grau de conhecimento insatisfatörio, e apresenta vārias feições em diferentes äreas.

A oeste, pröximo a escarpa da Serra da Ibiapaba, $\vec{e}$ pa tente a discordância ângular destas rochas com as rochas do emba samento. Os dobramentos são normais, com mergulho das abas, com vergência para noroeste definida pela inclinação do plano axial e uma sërie de falhas inversas. E comum a presença de clivagem de cisalhamento paralela aos planos axiais.

Mais a leste, a unidade se aloja totalmente no graben de Martinöpole, delimitado pelas falhas policiclicas de Jaguarapi (norte) e Itacolomi-Tucunduba. No interior deste graben os metas sedimentos se mostram intensamente dobrados, amarrotados, sem que se possa definir o padrão.

As inumeras falhas que seccionam a unidade (Xixäs, Pau Iista, Martinöpole), de direção NE-SW criam um mosaico de blocos alongados e paralelos, onde são comuns mais de uma fase de ativa ção. Isto se evidencia pela cataclase, brechação e silicifica ção, contatos abruptos, etc., de forma que esta dinâmica de cisa 1hamento $\vec{e}$ sobrepujante. Outros falhamentos (ENE, WS), de menor expressão cortam os falhamentos principais.

A dinâmica de falhamentos que obscurece a interpretação das fases e estilo de dobramento foi reativada outra vez mais no Cambro-Oroviciano, soerguendo äreas fontes e abatendo os blocos sobre os quais se preservou a sedimentação do Grupo Jaibaras.

\section{2 .2 - A Faixa Sudeste ("Ubajara/Jaibaras")}

A - O Grupo Ubajara (U)

A designação de Grupo Ubajara (NovAIS et al., 1979; NAS CIMENTO e GAVA, 1979) foi adotada para substituir o polêmico "Gru po Bambui" de COSTA et al., 1973 e assemelhados, muito usuais na bibliografia. A utilização de um termo de referência (Gruta de 
Ubajara) local tem propósitos exclusivos de clareza.

Esta unidade ocorre totalmente confinada a parte sul do graben/faixa "Bambui-Jaibaras", numa ärea aproximadamente retan gular de cerca de $1200 \mathrm{~km}^{2}$, sendo limitada pelas falhas de Arapa $(N W, N)$ e Cafe-Ipueiras (SE). A continuidade desta faixa é inter rompida a nordeste pelo granito de Meruoca e a sudoesta pelo grano diorito de Mocambo e pela cobertura da Bacia do Parnaiba. Todos os contatos externos desta unidade estão envolvidos em vigorosos traços de falha e a sua prōpria preservação se deve ao seu encaixa mento tectônico.

As rochas do embasamento que mais se aproximam de sua ärea de ocorrência são as do complexo gnäissico-migmatïtico, com intercalações quartzíticas. As relações de contato com a sequên cia vulcano-sedimentar (Grupo Martinópole e afins) não são conheci das por via direta. Hä indicações de ordem estrutural de uma pos ção sobrejacente, posto que os filitos e xistos que aparecem a nordeste do granito de Meruoca exibem um quadro de fases deforma cionais mais complexo. As relações de contato com o Grupo Jaibạ ras são de discordância angular e erosiva.

o Grupo Ubajara compreende um minimo de quatro unidades 1ito-estratigräficas cartogräveis, embora com contatos gradacio nais entre si, e mesmo interdigitados, as quais em conjunto mate rializam o registro de um ciclo tecto-sedimentar completo, em mar gem continental moderadamente subsidente. Na sua esteira lito-es tratigräfica, e tambëm estrutural, o Grupo Ubajara mostra uma se rie de semelhanças notäveis e sugestivas, com os Grupos Bambui e Vaza Barris, de idênticas faixas marginais, Brasilia e Sergipana.

As Formações Trapiä e Caiçaras, em conjunto $\left(U_{1}\right)$ consti tuem a sequência terrígena basal, consoante litofäcies psamítica (proximal) e pelitica (distal), onde são flagrantes as passagens laterais e interdigitações entre si. Representam um contingente de depösitos continentais, essencialmente clästicos, em atmosfera oxidante, e de caräter transgressivo, que atinge localmente $1500 \mathrm{~m}$ de possança.

A alternância de arenitos e siltitos micáceos de baixo grau de metamorfismo é o traço marcante do perfil da Formação Tra 
piâ. A monotonia de tipos litológicos, ardósias avermelhadas e brancos de arenitos é característica da Formação Caiçaras.

A Formação Freicheirinha $\left(U_{2}\right)$ corresponde à sequência carbonätica, caracterizando extenso predomínio da taxa de subsi dência sobre o influxo de clästicos, com raras oscilações. Trata-se de uma sedimentação marinha do tipo plataforma carbonática, em condições de moderada restrição. Representa o estágio estrati gräfico mais importante, pelo quadro paleogräfico e pela express $\underline{\dot{i}}$ vidade econômica das rochas calcärias $(0$ a $500 \mathrm{~m})$, contraposto a escassas interveniências clästicas. A Formação Freicheirinha mostra contatos gradacionais na capa e lapa com as sequências ter rigenas do ciclo.

A Formação Coreau $\left(U_{3}\right)$ consubastancia a sequência terrí gena superior, com uma associação de clästicos finos imaturos, do tipo "flysch" terrígeno tardio, tendo grauvacas, arcóseos e aren tos arcoséanos como litologias típicas, alternantes e sucedentes entre si. Tipos mais grosseiros, como grauvacas 1iticas e conglo merāticas, de caräter polimíctico, reforçam a interpretação de um período de regressão, com muita instabilidade tectônica. A espes sura estimada desta assembléia de rochas imaturas tangencia os $2000 \mathrm{~m}$.

- Grupo Ubajara mostra uma fase de dobramentos, de carạ ter holomörfico, que gerou dobras simëtricas mais ou menos isópa cas, com evolução locais à dobramento isoclinal, com eixos orien tados NE-SW, e plunges para NE e SW. Em algumas dobras nota-se a tendência a reversão e a inclinação dos planos axiais para sudes te (vergência para noroeste). A continuidade deste estilo de de formação plästica é interrompida por falhas inversas internas aó sistema (Frecheirinha, por exemplo) e pelas falhas externas (Arapa, a noroeste, Cafe-Ipueiras, etc.) que delimitam a ärea de ocor rência do grupo. Ainda, este esquema estrutural é interrompido a sudoeste e noroeste pela intromissão dos "stocks" graniticos in trusivos.

o caräter gerál do metamorfismo é em condiçōes epizo nais, variando a anquimetamorfismo em alguns pontos, mas faltam ainda estudos de termodinâmica. Nas zonas de contato com os gra nitos de Mucambo (aurēola conspícua e cartografävel) e Meruoca 
sobrepõe-se aos epimetamorfitos das Formações Trapiä, Caiçaras e Freicheirinha uma importante fase de termo-metamorfismo (Uh). Nas secções mais completas destas aurëolas tem se encontrado registro de zonação de fäcies albita epídoto - hornfels até piroxênio-hornfels.

\section{B - Magmatismo}

Dois "stocks" graniticos, epizonais, prototípicos de mag matismo pös-cinemätico do Nordeste $(\lambda 3)$ são conhecidos nesta fai $x a$, e objeto jā de värios estudos especializados.

0 "stock" de Meruoca-Rosārio tem forma de exposição apro ximadamente retangular, marcado por traços de falhas, numa ārea de cerca de $400 \mathrm{~km}^{2}$. Trata-se de uma rocha de composição alcalina a peralcalina, textura fina atë muito grosseira de coloração cinza a avermelhada, localmente esverdeada (faialita presente), com muito típicos intercrescimentos granofíricos e gráficos e cavidades miaro 1iticas.

A composição modal é de granito, quartzosienito e grani to a alcalifelspato.

Filiados ao "stock" de Meruoca hä uma prolífera geração de diques de direção NE, ENE, de composição variada, de dioritos a riolitos, seccionando as rochas do Grupo Ubajara, ao sul de Coreaú.

0 "stock" de Mucambo tem forma de pera, com ärea de $180 \mathrm{~km}^{2}$, seccionando fortemente o sudeste pela falha de Café-Ipuei ras. Sua composição ê variävel de granodiorito porfirítico a quartzo monzonito, quartzo sienito e hornblenda biotita granito (SIAL et al., 1981). Os fenocristais de feldspato localmente atin gem atẻ $10 \mathrm{~cm}$ de extensão. Autôlitos de variadas dimensão e compo sição e xenólitos das rochas encaixantes (migmatitos, quartzitos, calcārios, etc.) são muito comuns, com grau variävel de reação com a massa ígnea.

No Maciço de Santa Quitëria, na margem leste do domínio em anälise, hâ värios corpos graníticos intrusivos,grosseiros, por firiticos a biotita (Serra das Barriga, São Paulo, etc.), de carā ter epizonal, provavelmente da mesma idade dos plutōes de Meruoca 
e Mocambo, referidos ao limite Prë-Cambriano-Cambriano $30 \mathrm{m.a.)}$ por NOVAIS et al., 1979 e SIAL et a1., 1981.

\section{C - Grupo Jaibaras (J)}

O Grupo Jaibaras ocupa vários grabens e semigrabens er gidos em fases tracionais da tectônica brasiliana, principalmente consoante o feixe de geofraturas que delimita o sistema Mëdio Coreaú. A depressão principal é a da localidade topônima situada entre o lineamento de Sobral p.d. e a Falha de Cafë-Ipueiras. Ao longo do Sistema de Falhas de Jaguarapi-Araçās, na borda noroeste do sistema ficam as demais depressões, a sul e sudoeste de Granja, e pouco a norte de Viçosa.

As secções estratigräficas mais completas se acham

no graben de Jaibaras, onde a litoestratigrafia da unidade foi equa cionada nos ültimos anos (COSTA et al., 1973; JARDIM DE SA et al., 1979) resumindo uma prolifera bibliografia preexistente. Nas inū meras ocorrências das depressões mais setentrionais são muitas as defecções na coluna litoestratigräfica, afora naturais variações faciolögicas das unidades, em face da mudança das äreas fontes e regimes deposicionais. Mas prevalece sempre um mesmo panorama tec tônico-sedimentar, ligado à mecânica de blocos falhados.

O Grupo Jaibaras repousa em discordância angular e eros va com as rochas subjacentes (Grupo Ubajara, Grupo Martinöpole,com plexos gnäissico-migmatíticos), mas são frequentes contatos falha dos. Os poucos contatos diretos com os granitos são por falhamen tos, mas é consenso pleno a posição crono-estratigräfica mais rê cente para o Jaibaras. JARDIM DE SA et a1., 1979, assinalam a pré sença de fases tardias e marginais do granito de Meruoca atingin do em formas de diques o Grupo Jaibaras, constatação que demanda posterior reexame.

No seu enquadramento estrutural elito-estratigräfico o Grupo Jaibaras consubstancia radical mudança na ambiência geotectô nica da região. O surgimento de "rift valleys", a sedimentação de caräter ortomolássico e o vulcanismo fissural e extrusivo asso ciado, a intensa tectônica de blocos por reativação vertical de geofraturas do substrato, etc., são diagnósticos típicos dos está- 
gios de transição (TUYEZOV, 1966) para condições ortoplataformais (pós-Silüriano).

A Formação Massapê é maiormente constituída por brechas e conglomerados polimicticos, com grande variação no tipo de matriz e na natureza dos blocos contidos, os quais tem sempre estreito relacionamento com as fontes de suprimento. A matriz $\vec{e}$ areno-ar gilosa avermelhada e esverdeada e os clastos são de praticamente todas as unidades sotpostas. Trata-se de um depósito fanglomera tico, com condições continentais, com frequente reativação de re levo, e onde os clastos diminuem de tamanho com o distanciamento da ärea fonte, e cujas espessuras variam bruscamente de um local (1 000 a 1200$)$ para outro $(100-200 \mathrm{~m})$ da bacia de deposição.

$\mathrm{Na}$ ărea ao norte, a "Formação Ubari" de KORPERSHOECK et al., 1979 e o Membro Ubari de ROSSITER et al., 1981, retratam a grosso modo condições de sedimentação semelhantes (hâ uma possib lidade de deposição glacial), e dentro do possível, certa equiva lência estratigräfica.

A Formação Pacujā mostra contatos de lapa gradacionais com a Formação Massapê, e representa a passagem para variada ga ma de rochas psamíticas-arenitos arcoseanos, siltitos, grauvacas, lentes conglomeräticas e pelíticas - folhelhos micáceos - com cores avermelhadas e esverdeadas. Mais raramente, ocorrem hor zontes de rochas carbonäticas. Predominam estratificação em ban cosfinos a médios, planos paralelos, e espessura do pacote varia em função da subsidência diferencial da bacia de sedimentação, de 100 a $1300 \mathrm{~m}$. Suas litologias constituem uma assemblëia seme lhante aos "red beds", onde se pode identificar vārios subambien tes de sedimentação fluviatil madura. As Formações Massapê e Pa cujá estão mapeadas em conjunto (Jmp) em acordo com a descrição apresentada e com a escala do mapa.

o Vulcanismo Parapuí (Jpa) é composto por uma complexa suite de rochas vulcânicas (lavas, piroclastos) e corpos subvu1 cânicos, que sucedem no tempo, recortam e recobrem as Formações Massapê e Pacujá. São basaltos,dacitos, andesitos e riolitos, ge ralmente alterados (espilitizados e queratofirizados) e, de forma subordinada, diabāsios e gabros. 
As efusivas de carāter bāsico a intermediärio, com notá vel diversificação de tipos constituem mais de dois terços das 1 i tologias observadas, e apresentam caracteristicas de extrusões es paçadas em diferentes tempos.

$\mathrm{Na}$ porção central do graben de Jaibaras aparece o corte jo principal de diques e sills (complexo filoniano), os mais pos santes de diabäsios e gabros, às vezes uralitizados, com grande va riedade no aspecto textural e no quimismo.

COSTA et al., 1973, COSTA et a1., 1978 e JARDIM DE SA et a1., 1979 descrevem e discutem de forma detalhada caracteristicas adicionałs e a classificação da afinidade dessa atividade vulcâni ca variada e continental.

A Formação Aprazível (Jap) recobre em discordância todas as unidades subjacentes e ocorre em forma de mantos e prismas irre gulares e descontínuos, com espessuras variäveis de dezenas a cen tenas de metros. São conglomerados e brechas polimicticas, incluin do blocos angulosos e subangulosos de atë $1 \mathrm{~m}$ de extensão, extre mamente mal selecionados; hä amostragem nos seus clastos de todas as 1 itologias preexistentes inclusive e caracteristicamente blocos de rochas vulcânicas do ciclo parapuí. A matriz é grosseira, arcoseana, com vârias tonalidades. Retrata depösitos de cones alu viais e torrentes situadas ao longo de linhas de falha que foram reativadas e rejuvenesceram os relevos.

Predominam contextos maciços ou mal estratificados, com atitudes suborizontais. Hâ locais onde estes conglomerados estão drasticamente deformados (milonitos, cataclasitos subverticaliza dos) que denunciam movimentos recorrentes das grandes falhas regio nais.

Embora seja uma unidade, por seu tipo, diacrönica às 1 i nhas do tempo, sua posição pós-vulcanismo diagnostica idade no pe
ríodo Ordoviciano.

Os sedimentos do Grupo Jajbaras apresentam grau de dia gểnese elevado a muito elevado (MELLO, 1977), com comportamento isotópico (NOVAIS et al., 1979) dentro do campo do anquimetamorfis mo. 
Toda a tectônica do Grupo Jaibaras, como jä fartamente mencionado, e como pode ser deduzido do quadro lito-estratigräfico, $\vec{e}$ germanotípica. Intenso e renovado acionamento de falhas do subs trato e o basculamento diferencial de blocos pode ser deduzido. As formações oscilam de mergulhos subhorizontais a mergulhos de 30 a $45^{\circ}$, de acordo com a solicitação vertical do bloco onde posiciona das.

Algumas dobras induzidas, braquianticlinais e braquissin clinais de eixo subvertical, e outras sinuosas ondulaçöes podem ser detectadas localmente, em patente adaptação à mecânica dos fa lhamentos mais pröximos, de forma que o regime idiomörfico estä tipificado.

\section{3 - ELEMENTOS DA GEOCRONOLOGIA}

o estägio atual de reconhecimento da geocronologia deste domínio geológico permite aduzir uma série de conclusões prelimi nares, tendo por suporte os trabalhos de NOVAIS et al., 1979; SIAL e LONG, 1978 e SIAL et a1., 1981.

As rochas do embasamento expostas no Maciço de Granja e no "horst" de Tucunduba são provavelmente arqueanas, apresentando fenômenos de re-homogeneização isotópica no Transamazônico, e par cialmente no Ciclo Brasiliano. A isócrona de referência de idade $1190 \mathrm{~m} . \mathrm{a}$. (recalculada) para rochas do Maciço de Granja, referida por BRITO NEVES, 1975 , pela natureza dos litotipos amostrados e pe la razão inicial obtida, ē atribuída a eventos de re-homogeneização. provavelmente eventos ligados aos processos tectono-termais da ad jacente faixa/graben de Martinópole.

Dados K/Ar em minerais com uma ünica exceção, denotam o aquecimento destas rochas ao longo do Brasiliano.

As rochas da unidade vulcano-sedimentar de Martinöpole foram analisadas de forma muito dispersa, e que admite poucas con clusões. Os valores de idade convencional são prë-brasilianos (850$\left.1450 \mathrm{~m} . \mathrm{a}_{.}\right)$, com raras exceções, desde que seja utilizado valores de razão inicial na ordem usual de 0,708 $\pm 0,002$. As idades obti das atravēs de isöcronas de referência tendem a indicar idades bra silianas, para valores muito elevados da razão inicial (acima de 
$0,725)$. De certa forma fica evidenciado retrabalhamento (metamor fismo, tectonismo) desta unidade no Ciclo Brasiliano.

KORPERSHOEK et a1., 1979, baseados em estudo de isötopos de oxigênio do "Filito Pedra Verde" chegaram a resultados de ida de entre $2600-1800 \mathrm{~m} . \mathrm{a}$. , de julgamento dificil.

Para o Grupo Ubajara foi sugerida a idade $1000 \mathrm{~m} . \mathrm{a}$. pa ra processos de deposição, e $610 \mathrm{m.a}$. como idade da sua principal fase deformacional e metamorfismo. A idade minima de $580 \mathrm{~m}$. a. $\vec{e}$ assegurada para o metamorfismo regional desta unidade, pois este é - valor de idade (isöcronica) das intrusivas fissurais que o recor tam (NOVAIS et aI., 1979).

o granodiorito de Mocambo, bem como as intrusivas fissu rais do Ubajara, têm idade radiomëtrica em torno de $580 \pm 30 \mathrm{~m}$. a. o granito de Meruoca deve ter idêntica idade, mas não se pode ob ter dados diretos confiáveis por problemas petrolögicos especiais.

A Formação Pacujä do Grupo Jaibaras teve seus processos principais de transformação termodinâmica (diagênese alta e anqui metamorfismo) em torno de $535 \pm 27 \mathrm{m.a}$, no Cambriano. Os eventos de deposição não puderam ser determinados por dados radiométricos, sendo estimados em parte dentro do Cambriano, em parte ao longo do final do Prë-Cambriano.

o Vulcanismo parapui apresentou idades de resfriamento entre 480 e $510 \mathrm{m.a}$, ou seja, no final do Cambriano, e pelas ca racterísticas do mëtodo K/Ar, este ë um valor de idade pröximo ao de sua alocação na crosta. Como consequência desta observação, a Formação Aprazíve1, que contẻm clastos do vulcanismo serä de ida de ordoviciana.

o carāter discordante da Formação Serra Grande, de idade siluro-devoniana e que serve de limite superior de idade do Grupo Jaibaras, se ajusta bem as conclusões preliminares alcançadas pela geocronologia, até o momento. 


\section{5 - O DOMINIO SERGIPANO}

O domínio sergipano compreende o desenvolvimento do sis tema de igual nome, que em parte se propaga como cobertura na pró vincia vizinha (Craton do São Francisco) ao sul. Para norte, o ebasamento deste domínio se confunde (limite convencional transicio nal) com o do domínio centro-oriental (IV) adjacente, no âmbito do maciço Pernambuco-Alagoas, atē onde tambēm se inserem värias ro chas graniticas Iigadas a evolução do Sistema Sergipano.

O Sistema de Dobramentos Sergipano, na acepção de BRITO NEVES et a1., 1977, estende-se das costas dos Estados de Sergipe e Alagoas, onde alcança uma largura de $200 \mathrm{~km}$, até o sul da cidade de Curaçä, ao norte do Estado da Bahia. O sistema exibe uma forma aproximadamente triângular, com a direção do seu eixo variando de WNW-ESE (porção oriental) para NW-SE. (porção ocidental), e uma ex tensão longitudinal da ordem de $400 \mathrm{~km}$, forma que perfaz uma äreá da ordem de $45000 \mathrm{~km}^{2}$. O sistema ocupa o espaço entre o Craton de São Francisco, ao sul e sudoeste, e o maciço Pernambuco-Alagoas ao norte.

A Bacia de Tucano (centro e norte) secciona diagonalmen te o sistema, proporcionando duas äreas de exposição distintas, uma a leste (porção oriental) e outra a oeste (porção ocidental).

O Sistema, por seu turno, epresenta uma marcante diferen ciação geológica natural segundo duas faixas de dobramentos distin tas que apresentam eminente contraste de estilos estruturais e me tamörficos, a saber: a Faixa Sergipana s.s., ao sul, e a Faixa Sul Alagoana, ao norte, as quais se acham separadas por uma zona de dobramentos de caräter intermediärio ("a zona de Propriä").

Versando sobre esta unidade se encontra uma farta biblio grafia, mas que está relativamente bem condensada nos trabalhos de BRITO NEVES et al., 1978 e SILVA FILHO e BRITO NEVES, 1979.

Toda a ärea do sistema e zonas adjacentes acha-se inte grada em mapeamento geolögico 1/250.000, do "Projeto Baixo São Fran cisco/Vaza Barris" (SILVA FILHO et a1., 1977). Hä vārias partes da ärea mapeada em escalas de detalhe, $1 / 50.000$ e escalas supe riores. 
Recentemente um reconhecimento gravimëtrico e magnetome trico (RAND et a1., 1980) foi efetuado na região, cobrindo os dife rentes segmentos que compõem o Sistema Sergipano e as unidades geó tectônicas adjacentes, o qual de certa forma ratificou o consenso geotectônico obtido dos mapeamentos geolögicos regionais.

Värios esquemas e modelos de desenvolvimento tectogene tico jä foram propostos (SANTOS e SILVA FILHO, 1975, MELLO et al., 1977, BRITO NEVES et a1., 1977, SILVA FILHO et al., 1978a) para o sistema em epigrafe, inclusive dentro da conceituação moderna de Tectônica Global. Mas, persistem ainda resistências e outras difi culdades no registro geolögico preservado, e no pröprio grau de có nhecimento de toda a unidade.

\section{1 - A FAIXA SERGIPANA}

A Faixa Sergipana $\vec{e}$ considerada o segmento sul do siste ma justaposto e demarcante da borda nordeste do Craton de São Frañ cisco. O limite ao norte de seu desenvolvimento è convencionalmen te aposto, por alguns autores, nas falhas inversas do mëdio curso do Rio Sergipe, o que the dä uma largura média da ordem de $50 \mathrm{~km}$ na porção oriental de sua ärea de exposição. Na porção a oeste da Bacia de Tucano, a faixa reaparece bastante estreita, com largura mëdia de $15 \mathrm{~km}$, e marcada em ambos os bordos por regime de falhas inversas, indicando forte compressão para sul e sudoeste.

o embasamento da faixa $\vec{e}$ siälico, composto de rochas mig matiticas e granuliticas, que formam ao sul o próprio embasamento do Craton do São Francisco. Pelo quadro geolögico regional, ē no tório a discordância estrutural (e erosiva) entre os metassedimen tos da faixa e as rochas de seu embasamento.

As características gerais, litológicas, estratigräficas, estruturais, metamörficas, entre vārias outras, a posição geológi ca da faixa sergipana, consoante a quase unanimidade dos conceitos atê então emitidos refletem um desenvolvimento nos moldes de um "miogeossínclineo".

A 1ito-estratigrafia da Faixa Sergipana é relativamente simples, com bom grau de conhecimento en geral, sendo uma das pou cas äreas do Nordeste onde os problemas de cunho terminolögico es 
tão pröximos do equacionamento final. O contingente 1ito-estrati gräfico reflete o assoreamento procedido em margem continental de moderada instabilidade, com gradações lätero-verticais dos 1itos somas representativos do ambiente continental (ao sul) para am biente marinho (ao norte).

O relacionamento estrutural, lito e crono-estratigräfico entre as pithas sedimentares da faixa sergipana e da ärea peri cratônica (ao sul) ë relativamente bem conhecida, e restam algu mas düvidas de importância secundảria. No entanto, as relações com o espesso e variado pacote da faixa Sul Alagoana (e da zona a elas intermediăria) não são esclarecidas ainda.

Hâ algumas proposições de identificação crono-estrat gräfica (SILVA FILHO et a1., 1978a; JORDAN, 1971), sendo as dife renças litológicas pertinentes às mudanças no quadro paleogeogra fico e na ambiência geotectônica. Mas, hä argumentos (como em JARDIM DE SA et a1., 1981) de ordem estrutural que advogam uma po sição mais antiga no tempo para os metassedimentos da facção ala goana. Este de fato $\vec{e}$ um problema em aberto e relevante,aguardan do solução em investigações futuras.

o quadro lito-estratigräfico da faixa sergipana traz em seu bojo o registro de dois ciclos tecto-sedimentares praticamen te completos, um em seguida do outro, e guardando semelhanças ge rais entre si.

As rochas do primeiro ciclo - Grupo Miaba - afloram or lando e realçando a estrutural arqueada do Domo de Itabaiana, no qual a zona axial, com embasamento (complexo diatexitico, A) aflo rante, acha-se deprimida por erosão. Os quartzitos da Formação Itabaiana, discordantes sobre o embasamento, suportam imponente "cuesta", praticamente contínua, em torno do domo topônimo.

As rochas do segundo ciclo - Grupo Vaza Barris - são tambëm representativas de um evento transgressivo - regressivo completo, com passagens nitidamente transicionaos entre as forma ções que o compõem. Estas rochas se expõem ao longo da faixa, a leste e a oeste da Bacia de Tucano, formando o prisma principal de metassedimentos fortemente dobrados com vergência para o Cra ton do São Francisco. As rochas deste segundo ciclo se estendem às bordas da vizinha plataforma - Craton do São Francisco - ao 
su1, onde apresentam conotação estrutural pröpria e adequada às condições de estabilidade encontradas, sendo enfeixadas sob a de signação de Grupo Estância.

0 embasamento da faixa acha-se exposto na janela de $\mathrm{S} i$ mão Dias e na zona central do Domo de Itabaiana (capeado por sedi mentos modernos), sendo constituído por complexos gnäissicos e migmatiticos, com muitas intercalações de rochas bäsicas (A); 10 calmente hă registros de litologias na fäcies granulítico (A/g1).

As caracteristicas gerais deste embasamento, do ponto de vista litológico e estrutural (orientado $N-N E$ ) permitem equi. pară-1o àquele do Craton do São Francisco, subjacente ao Grupo Estância (aflorante a sul da ărea, compondo parcelas do chamado cinturão granulítico Atlântico) .

A oeste da Bacia de Tucano as exposições do embasamen to são extensas (Complexo gnáissico-migmatïtico, A, e graníticas $\lambda_{1}$ ) e acham-se esporadicamente recobertas por remanescentes vulca no-sedimentares (Tui, Tfi, Tcp) do Complexo de Serrinha, jā comen tados anteriormente.

\section{1 .1 - Grupo Miabâ (PEmb)}

O Grupo Miaba, no sentido de HUMPHREY e ALLARD, $1969 \vec{e}$ composto de três formações que ocorrem circundando o Domo de Ita baiana. A Formação Itabaiana se inicia por um nível conglomerāti co com seixos angulosos em matriz grauväquica. O resto de seu perfil é essencialmente de quartzitos feldspäticos, caindo o teor de feldspatos em direção ao topo. Níveis argilosos tem pouca ex pressão em espessura e continuidade. A estratificação cruzada $\bar{e}$ de média a grande porte. Espessuras variáveis, com mäximo de $1100 \mathrm{~m}$ e discordância angular bem marcada sobre as rochas diate xítica do domo homônimo, caracterizam esta unidade.

A Formação Jacarecica aflora quase exclusivamente no bordo leste do "domo", com espessura mäxima de $150 \mathrm{~m}$. E composta de meta-grauvaca seixosas e metaconglomerados polimicticos, com raras intercalações argilosas avermelhadas.

A Formação Jacoca tem espessura variäve1, atë $300 \mathrm{~m}$, ocor rendo a leste e oeste do Domo de Itabaiana, sobre a Formação Itâ 
baiana ou sobre a Formação Jacarecica. A despeito das unidades subjacentes serem continentais, a Formação Jacoca tem caracterís ticas marinhas, sendo composta de metacalcärios, metadolomitos e meta-argilitos escuros, com lentes de sílex.

Segundo SILVA FILHO et al., 1977, os contatos desta For mação com o Grupo Vaza Barris, são aparentemente normais, mas hä evidências de um carāter progradacional (SILVA FILHO, 1980) da Formação "Capitão/Palestina".

Por esta razão o Grupo Miaba é aqui apresentado na acep ção original de HUMPHREY e ALLARD, 1969, não incluindo pois a For mação "Capitão/Palestina" (diferente do proposto por SILVA FILHO et a1., 1978a, 1978b) que denuncia o início de um novo ciclo sedi mentar.

\section{1 .2 - Grupo Vaza Barris $\left(P_{\varepsilon} v b\right)$}

- Grupo Vaza Barris, na accepção adotada, envolve um cí clo sedimentar completo, iniciado por uma variada e progradante sequência terrígena basal, que passa transicionalmente para uma sequência calcäria, e desta para uma sequência terrígena superior, fecho do ciclo.

A Formação "Capitão/Palestina" $\left(\mathrm{Vb}_{1}\right)$ apresenta-se em dois litofäcies fundamentais que apresentam posições estratigräfi. cas variäveis em diferentes perfis. Compõem-se de filitos, ardō sias - "fäcies Capitão" - metarenitos impuros, metagrauvacas, me tagrauvacas com blocos polimícticos, de gnaisse, granito, quartzo, pegmatito, carbonato, etc., alongados na direção da clivagem ardo siana - "fäcies palestina". Rochas metavulcânicas têm sido aponta das, com pape1 subordinado.

A Formação Olhos d'Âgua (correlato da Formação Acauã) $\left(\mathrm{Vb}_{2}\right) \overrightarrow{\mathrm{e}}$ composta por metacarbonatos escuros, intercalados de cá1 cio-filitos e filitos. Os contatos com as formações confinantes são marcados por diversas interlaminações de calcärios, cälcio-fi litos e filitos. Hä ocorrências de estruturas algais, na região entre Simão Dias e Poço Verde. Localmente o caräter redutor do ambiente $\vec{e}$ marcado pelo odor fëtido nas fraturas e pela ocorrên cia de sulfetos.

A Formação "Frei Pau1o/Ribeiröpolis" $\left(\mathrm{Vb}_{3}\right)$ e constituída de filitos, metassiltitos, meta-arenitos finos de cores cinza es 


\begin{tabular}{|c|c|c|c|c|c|}
\hline \multicolumn{3}{|c|}{ 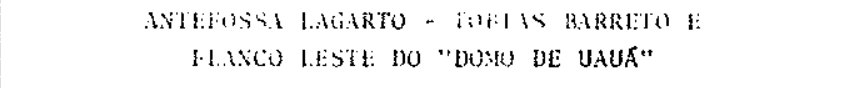 } & \multicolumn{3}{|c|}{$\begin{array}{l}\text { FAIXA SERGIPANA P.A. (GRUSO VAZA BARRIS) E } \\
\text { DOMO DI: ITABAIANA (GRLPO MIABA) }\end{array}$} \\
\hline & $\begin{array}{l}\text { 10RYACAO PALMARES } \\
(500-700 \mathrm{~m})\end{array}$ & $\begin{array}{l}\text { Arenitos e Grauvacas, finos a } \\
\text { médios, com fragmentos de ro- } \\
\text { cha e flocos de argilas } \\
\text { Intercalações de brechas e } \\
\text { conglomerados }\end{array}$ & & $\begin{array}{l}\text { FORMACAO JUK (intrafossil) } \\
\qquad 500-2000 \text { tn) } \\
\text { GRANITOS / GRANODIORITOS } \\
\text { (TIDO "GLORIA") }\end{array}$ & $\begin{array}{l}\text { Conglomerados, polinícticos, granl } \\
\text { vacas, arenitos arcoseanos, fi- } \\
\text { nos e conglomeráticos } \\
\text { QUaRTz0-Monzonitos intrusivos, } \\
\text { desenvolvendo contatos bruscos, } \\
\text { desenvolvendo "hornfelses" } 10- \\
\text { calmente, com xenólitos de xis } \\
\text { tos }\end{array}$ \\
\hline \multirow[t]{3}{*}{$\begin{array}{l}a \\
R \\
u \\
\vdots \\
\vdots \\
1 \\
1 \\
S \\
T \\
A \\
\vdots \\
\vdots \\
1 \\
1 \\
1\end{array}$} & 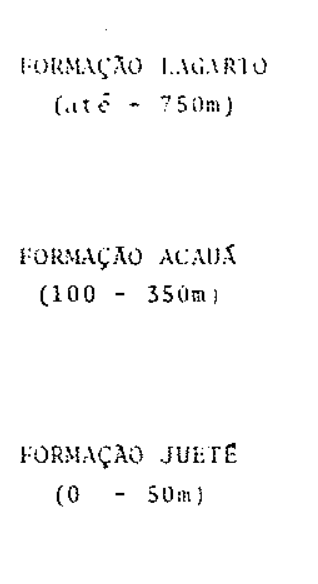 & $\begin{array}{l}\text { Argilas, siltitos, arenitos fi- } \\
\text { nos. calciferos,esverdcados } \\
\text { Arenitos, argilas e siltitos } \\
\text { vermelhos } \\
\text { Metacalcärios e metadolomitos } \\
\text { escuros, com níveis de argilí } \\
\text { to e siltito } \\
\text { Nívis algais frequentes } \\
\text { Arenitos feldspäticos médios } \\
\text { a grosseiros, conglomerados } \\
\text { descontinuos } \\
\text { Intercalaçōes clästicas finas }\end{array}$ & $\begin{array}{l}\mathrm{G} \\
\mathrm{R} \\
\mathrm{U} \\
\mathrm{P} \\
\mathrm{V} \\
\mathrm{V} \\
\mathrm{V} \\
\mathrm{A} \\
2 \\
\mathrm{~A} \\
\mathrm{~B} \\
\mathrm{~B} \\
\mathrm{~A} \\
\mathrm{R} \\
\mathrm{R} \\
\mathrm{I} \\
\mathrm{S}\end{array}$ & 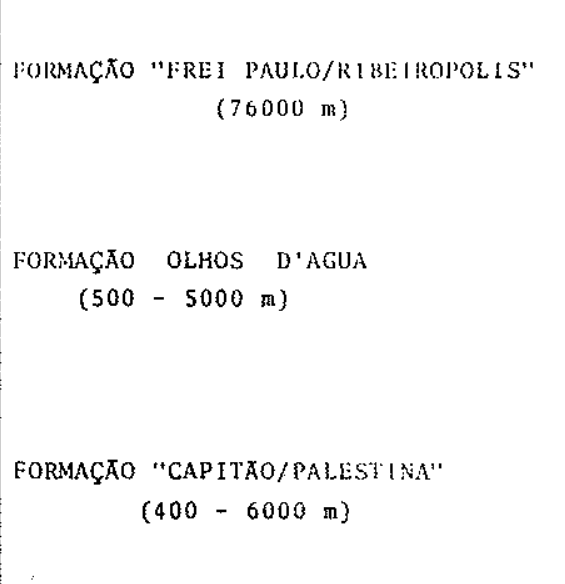 & 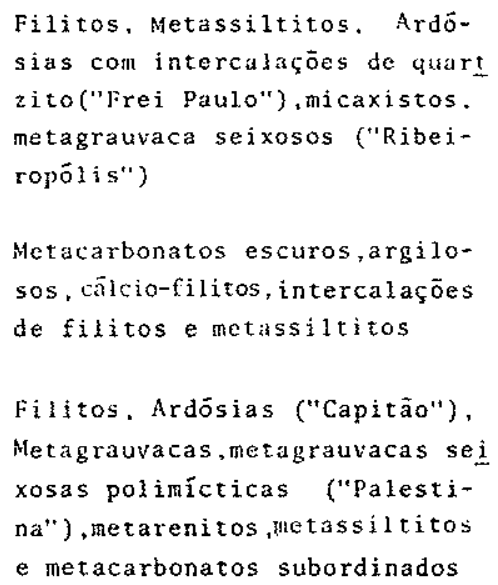 \\
\hline & & & $\begin{array}{c}\mathrm{C} \\
\mathrm{R} \\
\mathrm{U} \\
\mathrm{p} \\
0 \\
\mathrm{M} \\
\mathrm{M} \\
\mathrm{A} \\
\mathrm{A} \\
\mathrm{B} \\
\mathrm{A}\end{array}$ & $\begin{array}{l}\text { FORMAÇAO JACOCA } \\
(0-300 \mathrm{~m}) \\
\text { FORMAÇROO JACAREC ICA } \\
(0-150 \mathrm{~m}) \\
\\
\text { FORMAÇAO ITABA IANA } \\
(100-1000 \mathrm{~m})\end{array}$ & $\begin{array}{l}\text { Metacalcários impuros escuros, } \\
\text { com intercalaçöes de ardósias } \\
\text { c netargilitos } \\
\text { Metagrauvaca com blocos e sei- } \\
\text { xos de rocha quartzo-feldspätí } \\
\text { ca, com intercalaçöes de metar- } \\
\text { gilitos e metassiltitos } \\
\text { Ortoquartzitos. } \\
\text { Quartzitos feldspáticos com in } \\
\text { tercalações de metassiltitos } \\
\text { Conglomcrado basal }\end{array}$ \\
\hline & $\begin{aligned} \text { FONTE: SILVA FILHO } \\
\text { SHLVA FILHO. }\end{aligned}$ & $\begin{array}{l}\text { et alii, 1978a, } 1978 \mathrm{~b} \\
1980 \text { - Inëdito }\end{array}$ & & FONTE: $\begin{aligned} & \text { HUMPHREY \& ALLARD, } 1969 \\
& \text { SILVA FILHO et ali }, 1978 \\
& \text { SILVA FILHO et a } 2 i, 1977 \\
& \text { SILVA FILHO \& BRITO NEVES, } 19\end{aligned}$ & 8 - Modificadc \\
\hline
\end{tabular}


verdeados e röseos ("Frei Paulo"), e por micaxistos, metagrauva cas, metagrauvacas seixosas, com intercalações ritmicas de metä pelitos (fácies "Ribeirópolis"), sendo comuns horizontes e niveis quartziticos.

Os metassedimentos do Grupo Vaza Barris, a leste da. Ba cia de Tucano, acham-se estruturados numa ampla zona anticlinorial (Anticlinōrio de Pinhäo), na qual a sequência terrígena superior ocupa a zona axial, a sequência calcāria forma e realça topografi camente os flancos, juntamente com a sequência superior. Na por ção ocidental da Bacia de Tucano, a definição cartogräfica das diversas formações que compõem o grupo não e tão precisa demandando posterior detalhamento.

A natureza do contato e as relações estruturais entre - Grupo Vaza Barris (PeVb) e o Complexo Macururē (Pemc) não são conhecidas em plenitude. As linhas de falhas inversas utilizadas para definir este contato (estas falhas existem de fato) devem ser encaradas como contatos provisórios. Uma redefinição completa no Complexo Macururé e da antiga "Formação Ribeirópolis" de HUMPHREY e ALLARD se faz necessärio. De fato, ao norte destas linhas de falhas - a leste e oeste da Bacia de Tucano - tem-se contextos Iito-estruturais distintos. Para norte (Complexo Macururë) o pa drão estrutural $\vec{e}$ mais complexo.

\section{1 .3 - O Grupo Estância (Peest) e a Formação Palmares (}

O Grupo Estância considerado correlato do Grupo

Vaza Barris jaz na antefossa de Lagarto-Tobias Barreto, sobre rochas do embasamento do Craton do São Francisco. Hä algumas evidências de passagem lateral (faciológica, estrutural) de suas unidades para aquelas do Vaza Barris, mas em geral, não hä condiçōes (ex posição, topografia, falhas) para continuidade de exposição.

A Formação Juetê aflora somente em faixa muito estreita, com muitas descontinuidades (de exposição e sedimentação), de Euclides da Cunha para o norte, perfilando a borda de exposição do grupo. A localidade típica $\vec{e} \circ$ Rio Juetê, pröximo a BendegöBA. E composto por arenitos claros, médios a grosseiros, com vâa rios niveis conglomeräticos, polimíctitos (diamictitos da Serra 
da Borracha), e inclusive alguns bancos argilosos. Na secção tipo sua espessura é da ordem de $30 \mathrm{~m}$ apenas.

A Formação Acauã tem sua maior ärea de exposição (predo minando no grupo) na região de Euclides da Cunha (BR-116), afora ocorrências isoladas na Bahia, ao sul de Lagarto-SE. Esta unidade repousa concordantemente sobre a Formação Juetê, e em discordância angular e erosiva sobre rochas do embasamento.

E constituída essencialmente por calcärios e dolomitos escuros, com variações de tonalidade para cinza claro avermelhado, azulado, etc., com intercalações de argilitos, siltitos e mesmo arenitos vermelhos em diferentes secções conhecidas.

SILVA FILHO et a1., $1978 \mathrm{~b}$ conseguiram identificar dois pacotes lito-estratigräficos, o inferior caracterizado pelas inter calçoes de calcários e argilitos, e o superior constituído por ca 1 cärios e dolomitos, dispostos em bancos e estratos lamelares. Ocor rem sempre intercalações clästicas de cores creme, esverdeada e avermelhadas, com espessuras variäveis, desde milimetros ate $1 \mathrm{~m}$ de espessura, produzindo um bandamento muito bonito, retratando in termitência grande nas relações de suprimento e subsidência ao lon go da sedimentação.

Em Crisopölis e Euclides da Cunha (BA) são muito comuns estruturas estromatoliticas. No pacote superior hä ocorrências de niveis de calcärios ooliticos. As caracteristicas gerais da Forma ção Acauã sugerem deposição em ambiente marinho.

A Formação Lagarto tem suas melhores äreas de exposição nas imediações, e nas rodovias de acesso a cidade topônima, em Ser gipe, onde ela repousa em concordância sobre a Formação Acauã, ou em discordância, e por contatos falhados com as rochas doembasamen to. SILVA FILHO (1980) afirma haver ligação física, em superfície, entre as Formações Lagarto e Frei Paulo/Ribeiröpolis, podendo a transição entre ambas ser observada no campo.

A secção inferior da formação mostra arenitos, siltitos e argilas avermelhadas. Os arenitos sãa finos a mëdios, com estra tificação cruzada de mëdio a pequeno porte, e contém camadas de siltitos verdes como intercalaçōes. A secção superior $\vec{e}$ composta de argilas, siltitos e arenitos finos, calciferos, com estratifi 
cação em bancos pouco espessos, laminares, sendo característica cores esverdeadas. Estruturas sedimentares do tipo "marca de car ga", "chama", "bolotas" de argila são frequentes. Localmente hä niveis conglomeräticos.

Segundo SILVA FILHO et a1., 1978b, o pacote inferior re trata deposição fluviatíl e o pacote superior ambiente deltäico. A espessura mëdia desta unidade ë na ordem de 200-300 m, mas 1o calmente (subsuperfície) hä perfis de $750 \mathrm{~m}$ de espessura.

$\mathrm{Na}$ região de Lagarto não foi possivel ainda discrimi nar cartograficamente a Formação Lagarto (ai dominante) das expo sições sobrepostas da Formação Palmares, devido ao que elas apare cem juntas no mapa.

A FORMACAO PALMARES $(\varepsilon O p)$ ocorre sobre as rochas do Gru po Estância provavelmente em discordância paralela. Ela possui extensa ärea de exposição no sul de Sergipe, constituindo"serras" e chapadões muito dissecados, esparsamente sobrepostos à Formação Lagarto.

Do ponto de vista litolögico apresenta grande varieda de, tendo como traço comun cores esverdeadas e clastos das rochas metassedimentares da faixa Sergipana.

Arenitos e grauvacas médios a grosseiros, imaturos, com fragmentos de quartzo, feldspato, quartzito e filitos, angulosos, e com uma matriz cloritico-sercítica, com estratificação maciça a plano-paralela. Arenitos e grauvacas com blocos de granitos, quart zitos, e de filitos, com estratificação pouco desenvolvida.Fácies conglomeräticas ocorrem localmente, polimícticas com matriz grau väquica esverdeada, com grande variedade entre os contingentes de seixo e matriz.

Segundo SILVA FILHO et a1., 1978b a Formação Palmares foi formada em ambiente continental, com fluxo de detritos por deslisamento de norte (ārea fonte) para o sul (antefossa).

5.1 .4 - Magmatismo, Estrutura e Metamorfismo

O magmatismo da faixa sergipana $\vec{e}$ bastante discreto. Hă värias menções (HUMPHREY e ALLARD, 1969) a presença de metavul 
cânicas nas 1itofäcies Capitão e Ribeiröpolis, de caräter sinsedi mentar.

Nas imediações de Canudos/Bendegó, MENDES e SOUTO, 1966 identificaram uma dezena de "stocks", modestos em dimensão de com posição gäbrica, de forma alongada, entremetidos dentre filitos e cälcio-filitos do Grupo Vaza Barris, com bordos foliados e interpretados como "prë-orogênicos". Teores anômalos para cobre foram assinalados nestes corpos (Missão Geolögica Alemã/SUDENE, 1973).

A associação magmätica mais importante $\vec{e}$ formada pelo cortejo de intrusivas cálcio-alcalinas designadas genericamente de "Tipo Glöria". Estes corpos ocorrem caracteristicamente ao norte da faixa Sergipana, nos dois lados da Bacia de Tucano, sendo cons tituídos de granitos,granodioritos, quartzomonzonitos, etc., a bio tita, e a muscovita. São rochas de granulação mëdia a grosseira, às vezes porfiriticas, de cores claras com acentuada isotropia,com xenölitos frequentes (xistos são comuns) e variados, desenvolvendo localmente a formação de cornubianitos.

As rochas do Grupo Miaba acham-se estruturadas consoan tes o Domo de Itabaiana, que se assemelha a um domo gnäissico man teado, cuja direção de eixo e NNE-SSW. Observa-se mergulho centri fugo das unidades do Grupo Miaba.

As rochas do Grupo Vaza Barris (a leste da Bacia de Tu cano) acham-se estruturadas num amplo anticlinörio (Pinhão) de dí reção geral E-W. As dobras são similares, continuas, sendo gera 1 mente de pequeno ângulo apical e mesmo isoclinais. o dobramento desenvolve uma $x i s t o s i d a d e ~\left(s_{1}\right)$ incipiente, acompanhando de certa forma os planos axiais, os quais se inclinam para norte e nordes te, caracterizando vergência para o sul. Associam-se a este esti 10 falhas inversas mesmo empurrões no flanco invertido, confirman do o deslocamento de materiais de norte para sul. Esta única fase de dobramentos, em nivel crustal superior não atinge as rochas do embasamento. Mas, os falhamentos inversos são capazes de alçar cunhas do embasamento, como ê testemunha a "janela" de Simão Dias.

Fases de deformação posteriores, e de menor vulto, desen volvem crenulação, clivagem de fraturas, dobras, "kinks", etc. de localização restrita. 
Na porção oeste da Bacia de Tucano, o conhecimento es trutural $\vec{e}$ incipiente ainda. 0 quadro observado atual $\vec{e}$ de um es tilo homoclinal, associado com falhas inversas e empurrões dirigi dos de nordeste (faixa) para sudoeste (craton), o que pode ser re sultado de uma deformação sobreposta à fase principal de dobramen tos.

As rochas do Grupo Estância (e da Formação Palmares)mos tram um estilo estrutural de plataforma, idiomörfico. As deforma ções estão vinculadas ao jogo de zonas de falhas do substrato. Pre dominam mergulhos suaves, pequenas ondulaçōes de grande comprimen to de onda, não hả desenvolvimento de xistosidade, salvo ao longo de linhas de falha.

0 metamorfismo regional dos Grupos Miaba e Vaza Barris $\vec{e}$ no fäcies xisto verde baixo, em geral, e monofásico, pelos estu dos preliminares até agora realizados. Hä värias menções a um tị po de metamorfismo de pressões intermediārias e mesmo de pressão alta (SILVA FILHO et al., 1978a), mas faltam estudos específicos.

o Grupo Estância e a Formação Palmares apresentam estạ gio de transformação termodinâmico intermediârio entre diagênese elevada e início das condiçöes de metamorfismo (BRITO NEVES et al., 1977), em alguns esparsos pontos de investigação.

Metamorfismo de contato foi descrito com detalhe na par te imediatamente ao norte da faixa Sergipana, por HUMPHREY e ALLARD, 1969, ao longo da zona palmilhada pelos "stocks" intrus vos jä mencionados.

\section{2 - A ZONA INTERMEDTARIA}

Uma zona de dobramentos com caracteres peculiares se insinua ao longo do paralelo de Propriä, entre as faixas Sergipana e Sul Alagoana. Sua delimitação ao sul $\vec{e}$ convecionalmente locada ao longo das falhas de"São Miguel Aleixo". Esta "zona axial de dí vergência" imprime uma simetria bilateral ao sistema como um todo, tendo sido diferenciada de forma preliminar desde o trabalho de HUMPHREY e ALLARD, 1969 , ainda que com outra conotação geotectôno ca. A definição, delimitação e interpretação correta desta zona 
imprescinde de detalhamento estratigräfico e estrutural.

Do ponto de vista lito-estratigráfico, esta zona corres ponde ao Complexo Macururé (Grupo Macururé de BARBOSA, 1970 e SIL VA FILHO et al., 1977), no mapa anexo. Tratam-se, na realidade, de metassedimentos extremamente rítmicos e bandados, metamorfisados em baixo grau com variações. O dobramento é isoclinal, com desenvolvimento de xistosidade plano axial bastante ondulado (redobramento), em parte sem vergência definida. À medida que o observa dor se distancia para sul e para o norte de propriá, observa-se gradativa arregimentação da vergencia consoante às faixas Sergipa na (ao su1) e Sul Alagoana (ao norte).

Trata-se de uma zona tambëm caracterizada pelo arquea mento do substrato, que se expõe em alguns setores, pela localiza ção preferencial de rochas graníticas (e metamorfismo termal asso ciado) e por ativa movimentação tectônica vertical, o que levou o autor (BRITO NEVES, 1975) designä-la de "Zona Geoanticlinal de Pro
priä".

Exposições do embasamento têm sido apontadas em Pro priä (cortada por granitos intrusivos), Igreja Nova, Monte Alegre, Pedro Alexandre, etc. afora indicações outras de posição subaflo rante.

Registros adicionais de patente atividade tectônica des ta zona são a presença de "wild flysch" (BRITO NEVES et a1.,1977a) em Graccho Cardoso, SE, a intrafossa molássica de Juä-Fazenda de Dentro, entre outros de menor monta.

Em Graccho Cardoso, $35 \mathrm{~km}$ a oeste de Propriä, ocorre uma unidade litológica complexa caracterizada pela presença de blocos de filitos, filitos grafitosos, "boulders" graniticos, fragmentos de rochas do embasamento(gnáisses, migmatitos, pegmatitos) com di mensões de centïmetro atê um metro. Hä praticamenta ausência de matriz (metapelítica, metarcoseana) em certos trechos do depósito. Nos blocos de metamorfismo epizonal observa-se dobramento prëvio e xistosidade, caracterizando a natureza tardia de depösito.

A Formação Juä $(\varepsilon 0 j)$ preenche grabens a leste de Jere moaba, BA, sendo constituída de conglomerados polimícticos e grau 
vacas que se alternam em vários niveis. Os conglomerados apresen tam seixos de metassedimentos, rochas graniticas, rochas efusivas e rochas do embasamento, com dimensões que atingem atē $30 \mathrm{~cm}$. As grauvacas aumentan de incidência para o topo da unidade, são esver deadas e acinzentadas e apresentam fragmentos de rocha bastante angulosos.

\section{3 - FAIXA SUL ALAgOANA}

A faixa Sul Alagoana apresenta muitas irregularidades na ärea de ocorrência, de modo que precisar sua forma e localizä- la geograficamente è uma tarefa difícil.

Ao sul, sua passagem para a faixa Sergipana se faz atra vës de ampla ärea transicional - atravēs da zona axial de diver gência, ou de forma muito brusca, induzida por falhamentos (por ção ocidental, norte de Canudos), de modo que em ambos os casos ë difícil precisar a delimitação. Ao norte, os processos de migma tização de seus metassedimentos, metavulcânicas, etc., assumem grandes proporções, tornando difícil o discernimento entre essas 1itologias e os migmatitos do embasamento, os quais se estendem ao vizinho Maciço Pernambuco-Alagoas. Ao lado disto, o sistema de falhas inversas e de empurrão que se estende de Jacarë dos Homens ao sul de Macururé conduz a um considerävel aloctonismo tardio das rochas graniticas, gnäissicas e migmatíticas de bordo sudoeste do Maciço Pernambuco-Alagoas, e assim prejudica a apreciação đas reais extensão e delimitação da faixa.

Toda evolução da faixa Sul Alagoana $\vec{e}$ marcada por gran de mobilidade tectônica e quadro diversificado de atividade magmá tica, caracteristicas condizentes (em parte) com os clässicos domí nios "eugeossinclinais". E, assim, esta equiparação tem sido feí ta (BRITO NEVES, 1975; SANTOS e SILVA FILHO, 1975, etc.) sendo inerentes a ela os problemas de sempre relativos ao conceito e ao mode10.

Outras manifestações igneas de menor parte, diques gra niticos, pegmatitos, etc. incidem com frequência na faixa sul Ala goana, concorrendo para consignar um quadro de grande mobilidade e intensa e variada atividade magmätica. 
O conhecimento lito-estratigräfico da faixa Sul Alagoa na ë ainda precärio, e requer uma sucessão de estudos adicionais. Um sem nümero de designaçōes para-estratigräficas tem franca cir culação, mas, atē o processo de formalização e equacionamento, hä muitas indagações a serem sanadas.

Como jä rapidamente mencionado, em certos setores da faixa, a distinção entre as rochas do embasamento e as sequéncias supracrustais da pröppia faixa não pode ser feita de forma clara.

Alëm disso, entre as unidades litolögicas da pröpria faixa (Complexo Macururë, "Complexo Piranhas-Canindë'if), as rela ções crono-estratigräficas são desconhecidas ainda. Entre os me tamorfitos que se expõem nas porções oriental e ocidental da fä́ xa hă algumas diferenças a serem consideradas, de ordem estrutŭ ral e quanto ao estägio de transformação termodinâmica, de sorte que a designação de Complexo Macururê continua no sentido opera cional que foi promulgado (0. BARBOSA, 1964-1970, Grupo Macururê). Por somatória maior de motivos ë informal e provisória a designa ção de "Complexo Piranhas/Canindë", aqui introduzida.

As rochas do embasamento da faixa sul Alagoana afloram nos nücleos das estruturas anticlinoriais, sendo constituidas de litologias muito variadas, de grau de metamorfismo no fácies anfi. bolito alto a granulito, a que LEITE, 1969 deu a designação de Grupo Jirau (A/g1).

Predominam rochas gnäissicas de composição granodio ritica a quartzo dioritica, e migmatitos com estrutura nebulitica, estomatitica e oftálmica. Localmente tem sido registrado a pre sença de gnaisses kinzigiticos e granulíticos, bäsicos a interme
diärios.

Importantes intercalações, de reduzidas dimensões e grande persistência, são conhecidas, no seio dos gnaisses e migmatitos. Nelas estão presentes anfibolitos, cālcio-silicäticas, mārmores, diopsídio dolomitos, quartzitos hematiticos,actinolita-tremolita a xistos, xistos antofiliticos (com asbestos e talco), etc. alinhados consoante os traços de foliação regional, como nos antiformes de Jirau do Ponciano e Arapiraca e na exposição do em basamento ao norte do. pröprio sistema. 


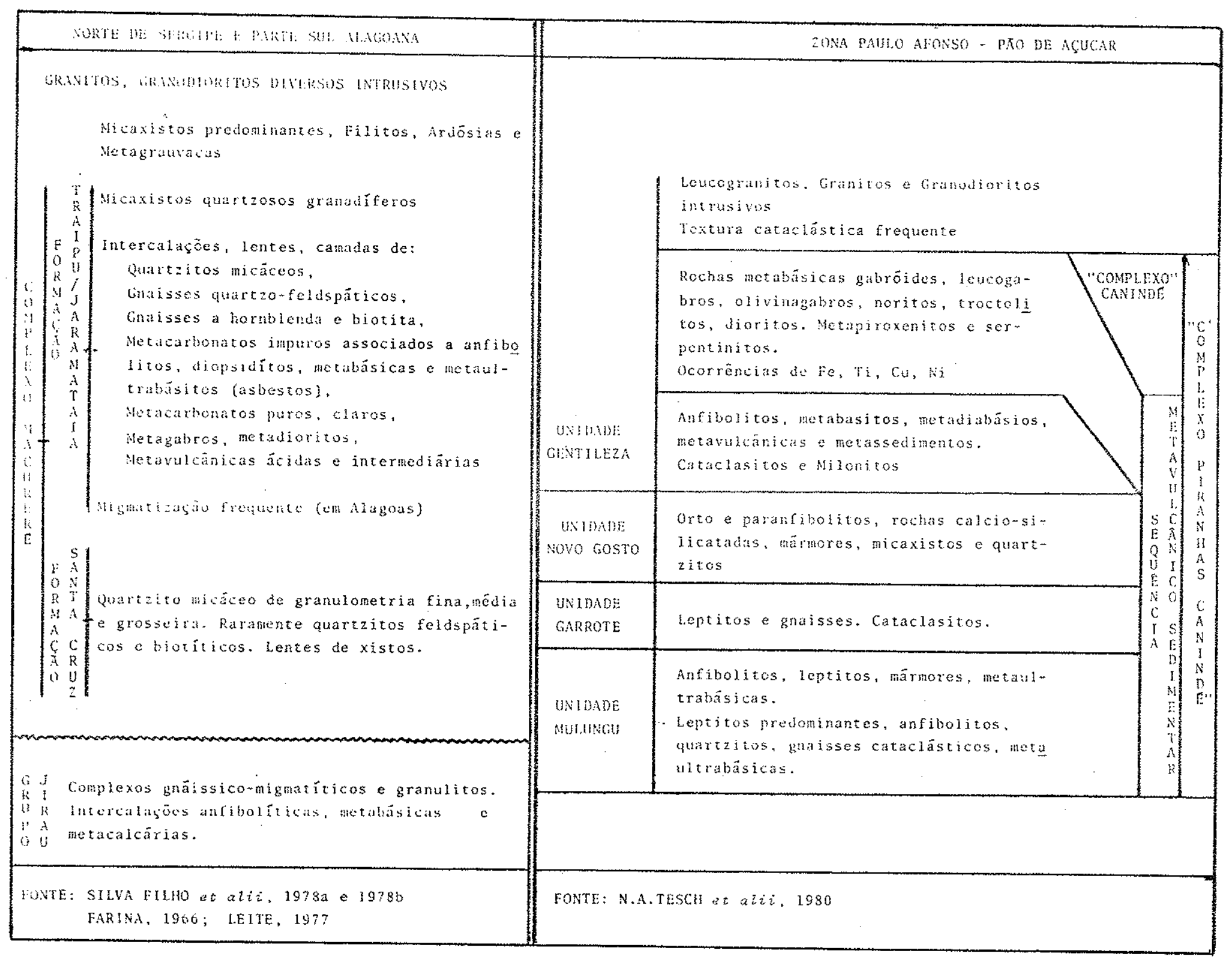

QUADRO 5.2 - ESQUEMAS LITO-ESTRATYGRAFICOS NA FAIXA SUL ALAGOANA 


\section{3 .1 - OComplexo Macururē (PEmc)}

a) A FORMAÇAO SANTA CRUZ (LEITE, 1969 (qz) ocorre dis cordante sobre o embasamento e subjacente a Unidade Traipü-Jaramataia e aflora principalmente circunscrevendo as principais estru turas anticlinoriais da ärea, formando geralmente cristas eleva das e bastante contínuas. As rochas dessa unidade são predominan temente quartzitos claros, com granulometria variando de fina a grosseira. Componentes eventuais são feldspato, biotita e serici ta. Mais raramente aparecem intercalações de rochas xistosas, quartzitos ferruginosos e metarcöseos.

b) A designação informal de FORMAÇAO"TRAIPU-JARAMATAIA", adotada por SILVA FILHO et a1., 1977 procurou reunir designações anteriores não adequadas de "hornfels Traipu" ou "pelitico" e "hornfels quartzo-feldspätico", ou "Jaramataia" de RICHTER e PON TE, 1964 e RICHTER, 1966, em escala de amplo reconhecimento regio na1. Na porção ocidental do sistema, O. BARBOSA, 1964-1970 iden tificou a continuidade destas litologias sob a designação igua $\underline{1}$ mente informal de "Grupo Macururë!"

$\mathrm{Na}$ realidade, a unidade considerada abrange uma multi forme e diversa sequência de rochas metassedimentares terrígenas com níveis químico e clästico-químico subordinados, rochas vulcâa nicas e rochas plutönicas de natureza bäsica e ultra bāsica,trans formadas termodinamicamente em niveis mesozonais e epizonais. De forma que a designação mais apropriada seria a de Complexo, que em escalas maiores fatalmente serä desemembrada em värias unida des distintas.

Como jä mencionado esta unidade jaz concordantemente sobre a Formação Santa Cruz. Suas relaçöes com as rochas dos Gru pos Vaza Barrisie Miaba, e com as rochas do Complexo Canindé e meta-vulcânicas associadas não poderam ser esclarecidas ainda.

As litologias predominantes desta unidade variam com a ärea de ocorrência. Geralmente, micaxistos quartzosos granadífe ros, gnaisses biotiticos granadiferos com muito niveis e interca lações de gnaisses quartzo-feldspáticos, quartzitos, anfibolitos, meta-gabros, metadioritos, meta-ultrabasitos, etc. Em algumas äreas ocorre migmatização de forma diversa ("agmatitos", "metasso 
matitos", "arteritos", etc.) e a distinção para com as rochas do embasamento se torna bastante difäcil, de possibilidades remotas (por exemplo, na borda centro sul do Maciço Pernambuco-Alagoas).

Numerosas intercalações de metacarbonatos associados a para e ortoanfibolitos são particularmente destacáveis na re gião de Batalha e Jaramataia-AL, e presença tambëm de rochas u trabäsicas portadoras de asbestos antofilitico.

Muitas outras intercalaçöes e ocorrências säo dignas de menção, destacando-se do quadro geral de micaxistos e gnaisses granadiferos, como quartzitos, gnaisses arcoseanos, cálcio-silicá ticas, mārmores, metavulcânicas àcidas a intermediärias, corposde gabro e diorito foliados, etc., etc., muitos dos quais sö carto grafāveis no detalhe.

O metamorfismo regional, como serä mencionado, que afe ta a unidade, em geral decresce de norte (Maciço Pernambuco-Alagoas) para o sul (Zona axial de Propriä), e isto acrescenta cer tas variedades no quadro petrogrätico regional. Filitos, ardösias, meta-arenitos, xistos luzidios aparecem mais para o sul das äreas de ocorrências desta unidade. Na porção ocidental da faixa (a oeste de Tucano), via de regra o metamorfismo regional $\vec{e}$ mais baj xo, mas são muitas as variações numa secção transversal.

\section{3 .2 - "Complexo Piranhas/Caninde"" (Pع.ca, gb)}

Uma importante e complexa sequência meta-vulcânico-sedimentar (Pão de Açücar-Paulo Afonso) ocorre associado a metaplu tônicos bäsicas e ultrabäsicas ("Complexo Canindẹ" s.s.), no flan co sul do chamado Maciço Pernambuco-Alagoas, com relaçōes de con tato ainda não definidos, com as rochas do embasamento e com as rochas da Unidade Traipü-Jaramataia. Ou, quando muito, em fase atual de definição; a Unidade Traipü-Jaramataia reüne contingente maior de metassedimentos exögenos, clästicos, A conjugação dos termos/unidade "piranhas/Caninde" faculta melhor apreciação na es cala ao milionësimo, e tem caräter informal.

Inicialmente, todo este contexto foi atribuido por SIL VA FILHO, 1976, a uma "sequência ofiolítica do geossinclinal Ser gipano", tendo posteriormente diferenciando-a em duas partes: $\bar{A}$ 
"Sequência Metavulcano-Sedimentar" representaria estägios magmāti cos prë-orogênicos (o que é um fato) e o "Complexo Canindë", s.s., representaria estägios sin e pös-orogênicos.

Segundo TESCH et al., 1980, o "Complexo Caninde"", na conceituação mais recente é posterior a sequência vulcano-sedimen tar (contatos em parte por falhas), sendo composto essencialmen te de rochas gabróides (gb), por sua vez cortadas por rochas gra nïticas $\left(\lambda_{2}, \lambda_{3}\right)$ de värias gerações. São rochas do tipo metaga bros, leucogabros, troctolitos, noritos, e mesmo frações de piro xênitos e peridotitos.

Esta área mostra teores anômalos de cobre e nìquel, com pequenos jazimentos (ocorrências subordinadas de prata, ouro e platina).

\section{3 .3 - Estrutura e Metamorfismo}

A estrutura da faixa Sul Alagoana $\vec{e}$ bastante complexa, e envolve claramente a superposição de eventos de várias fases de deformação. As grandes dobras regionais, os alinhamentos observa dos nos mapas geológicos são delineadaș por traços de foliação, os quais em qualquer escalas exibem padrões de redobramento.

Recentemente JARDIM DE SA et al., 1981, reportou qua tro fases distintas de deformação nas rochas desta faixa, e pelo menos três fases de metamorfismo associadas. Os grandes dobramen tos regionais são caracterizados por formas cerradas, paralelas e até mesmo isoclinais, inclinadas a invertidas, cujos planos axiais têm mergulho forte para $S$ e $S W$, e os eixos caem de modo suave pa ra WNW e ESE. Estes dobramentos de foliação evoluem para falhas inversas de flanco invertido, desenvolvendo marcante lineação nos quartzitos da Formação Santa Cruz, compondo um quadro geral de ver gência dirigida para $N$ e NE, para o Maciço Pernambuco-Alagoas.

Esta fase regional de dobramentos, atingindo inclusive - embasamento da faixa, sofreu värias deformações posteriores, de localização restrita ("kinks", crenulação, etc.). De conota ção mais ampla hã uma fase de forte compressão, de carāter tardio, de sentido norte-sul resultando em falhas inversas e empurrões, e mesmo formação de cataclasitos e redobramentos, localizada no bor 
do sudoeste (Jacarë dos Homens/Macururë) do Maciço Pernambuco-Ala goas, o qual mascara grande parte da vergência para o norte defini da no regime tectônico anterior.

Este processo mascara grande parte da vergência defini da no regime tectônico que the antecedeu, e, assim sô na parte mais oriental do sistema fica preservado um quadro residual de ver gências centrifugas, definidas a partir do paralelo de propriá.

$\mathrm{Na}$ porção ocidental, a mecânica tardia de compressão de nordeste para sudoeste $\vec{e}$ predominante, e abrangente, atingindo todo o sistema. E de forma a obscurecer presença de estilos de dobramentos anteriores, resultando pois numa feição .. homoclinal vergente para o Craton do São Francisco, vista nos mapas, nitida mente uma feição sobreposta.

Em consonância com a história estrutural polifäsica, as paragêneses minerais da faixa mostram tambêm uma evolução comple xa. De uma maneira geral, na porção oriental a fäcies de metamor fismo regional cresce de sul (xistos verdes) para norte (anfiboli to alto), onde a migmatizaçāo é frequente. Os estudos de mine rais indices e tipos de metamorfismo são ainda a nível muito pré liminar e questionảvel. Hä indicações (JARDIM DE SA et a1.,1981) no sentido de metamorfismo regional de pressão baixa $\left(M_{1}\right)$ a inter mediäria $\left(M_{2}, M_{3}\right)$ ao longo das principais fases de deformação.

$\mathrm{Na}$ porção ocidental da faixa também se verifica a preseruça de rochas epi e mesozonais (JORDAN, 1971,"sequênciagnäis sico-filítica". Mas a distribuição de fäcies é diferente, pois se nota sensivel aumento de grau de metamorfismo no centro da fai xa (fácies almandina-anfibolito), e decrëscimo para seus bordos (subfácies quartzo-albita, epídoto-almandina da fácies xisto ver de ).

5.3 .4 - Magmatismo

Afora a atividade magmätica $j a ̈$ mencionada no discorrer da sequenciação lito-estratigräfica da fałxa Sul Alagoana, merece destaque considerävel nümero de rochas graniticas $\left(\lambda_{3}, \lambda_{2}\right)$ e sie niticas de posicionamento tardio, presentes na borda sul do Maci ço Pernambuco-Alagoas. Principalmente, são dignos de menção os corpos da ärea entre Bom Conselho (PE) e Paulo Afonso (BA), e cor 
tando rochas do embasamento e da supraestrutura, e mesmo rocha gra niticas preexistentes.

Os granitos e granodioritos do tipo "Glória" menciona dos ao norte da faixa Sergipana, estão presentes na faixa Sul Ala goana, e principalmente no seu ramo ocidental, ao sul de Macururë.

No flanco sul do Maciço Pernambuco-Alagoas são destacă veis grandes corpos de composição granítica (leucogranitos) e adamelítica com poucos mäficos, granulaçäo fina a media, cortando de forma brusca diferentes tipos de encaixantes. São caracterís ticas adicionais inumeros enclaves de metacarbonatos, anfibolitos e rochas bäsicas. A estas rochas, SILVA FILHO et al., 1977 atr $\underline{i}$ buiu a designação de tipo "Mata Grande".

Ao longo da mesma ärea, cortando rochas do embasamento e os pröprios granitóides previamente descritos, ocorrem diques, corpos alongados e "stocks" de rochas graníticas, quartzo-sieníti cas e sieniticas (si), designados de tipo "Águas Belas", por SIL VA FllHO et al., 1977. São rochas de coloração rósea a muito cla ras, granulação mêdia a grosseira, às vezes porfiritica, sempre apresentando hornblenda, enclaves hipermäficos, e, eventualmente clino-piroxênio (aegirina-augita).

Ao norte esta ärea, mais para o centro do Maciço Per nambuco-Alagoas, são destacáveis granitos e granodioritos a duas micas (tipo "Cariba"), de caräter tardio, tendo fluorita e topä zio como acessórios característicos (a oeste de Aguas Belas, $\lambda_{3}$ ).

\section{4 - SUMULA DOS DADOS GEOCRONOLOGICOS}

o nível do conhecimento geocronológico do sistema ser gipano como um todo e deveras rudimentar ainda, fruto de raros tra balhos de reconhecimento.

Para as rochas do embasamento, idades $\mathrm{Rb} / \mathrm{Sr}$ em rocha total e K/Ar em minerais asseguram efetiva participação nos even tos do Ciclo Transamazônico. No nücleo do anticlinörio de Jirau do Ponciano (BRITO NEVES, 1982) foi obtida uma isócrona de referên cia de $2200 \mathrm{~m} . \mathrm{a}$. para as rochas gnäissicas e migmatíticas do em basamento. Uma determinação isolada, $\mathrm{Rb} / \mathrm{Sr}$ em rocha total, em 
Simão Dias revelou uma idade convencional de $2500 \mathrm{~m}$.a. Ha possi bilidade de serem encontrados outros registros geocronológicos do Arqueano tendo em vista o contexto geológico regional, com a presença de rochas granulíticas avindas da projeção do embasamento do Craton do São Francisco.

os dados radiométricos disponíveis para os metamorfí. tos do sistema, em ambas as faixas, são escassos e mostram disper são de valores de 520 a $670 \mathrm{~m} . \mathrm{a}$. (K/Ar e Rb/Sr), não deixando a $\underline{1}$ ternativas de conclusão. A possibilidade de uma vida crustal mais antiga para a faixa Sul Alagoana, evidenciada pela presença de um nümero maior de fases deformacionais, não pode ser ainda clarificada pela escassez dos dados radiomëtricos.

A idade obtida para o anquimetamorfismo do Grupo Estân cia (Formação Lagarto), por BRITO NEVES et al., 1977, no valor de 490 m.a. é considerada como mínimo para o grupo em 1 ide e seus cor relatos inclusive o Vaza Barris. Idade de sedimentação em ambas as faixas é um problema sem resposta ainda.

Conjunto bem coerente de dados se refere aos granitói des tipo "Glöria" para o qual se obteve uma isócrona de referên cia de $660 \pm 35 \mathrm{~m} . \mathrm{a}$. (BRITO NEVES e CORDANI, 1973). 0 caräter in trusivo destes corpos faz com que esta seja uma idade mínima para os metamorfitos que recorta.

Os dados de resfriamento, $\mathrm{Rb} / \mathrm{Sr}$ e K/Ar em micas, indi cam o amplo intervalo de 560 - 600 m.a. para os corpos graniticos, na maioria das vezes, o que deve corresponder à fase de exumação erosiva e soerguimento regional. 


\section{6 - DOMINIO CENTRAL (V)}

0 dominio central se refere a zona mais interna do de senvolvimento geológico Pré-Cambriano da região nordeste, à qual se dispõe diagonalmente, reunindo os sistemas metassedimentares mais importantes e integros ("orogenic belts"). Ao longo desta zona é notōria a preservação de supracrustais terrígenas do Prote rozöico, contínua e linearmente dobradas (NNE-NE/SW-NNE), cortadas por grande afluência de rochas graníticas do Ciclo Brasiliano.

Ao longo deste cinturão de metamorfitos foram realiza dos mapeamentos geológicos considerados como clássicos para a região, e que sediaram praticamente a maioria da profusa terminologia $1 \underline{1}$ to-estratigrafia pré-Cambriana usualmente em circulação no Nordes te.

Os limites propostos para este domínio são convencio nais por definição, sendo mais ou menos orientados pela forma de distribuição alongada e preservação preferencial das supracrus tais (do Proterozóico aos nossos dias), e que certamente têm ra zōes geodinâmicas primärıas. Nos domínios confinantes persistem vestígios (restos de supracrustais, graníticas) de uma extensão mais ampla que aquela que se permite hoje formular, perante critê rios virtuais, circunstanciais.

0 dominio central apresenta-se segmentado pelos linea mentos Patos e Pernambuco, consubstanciando compartimentos (Va, $\mathrm{Vb}, \mathrm{Vc}$ ) que reunem uma série de características geológicas - lito genéticas, estruturais, metalogenéticas - mais ou menos próprias. A concepção dos sistemas de dobramento Seridó, Piancó-Alto Bríg da e Riacho do Pontal deve ser compreendida como compartimentação geometrico-estrutural de referência, para descrição, de um contex to maior, cuja configuração paleogeológica é muito difícil de reconstituir.

\section{1 - O SISTEMA DE DOBRAMENTOS SERIDO}

Sob esta designação se enfeixa o segmento norte do do mínio central, que em todos os aspectos imaginâveis, é a mais im portante ärea da geologia do Nordeste. 
Eే a ârea-foco de inúmeros trabalhos de H. EBERT ao 1 on go de quase duas décadas, ärea de pesquisa preferencial dos pro fessores dos Cursos de Geologia do Recife e Natal, e dispondo atualmente de värios mapeamentos na escala de semidetalhe e detathe (DNPM/CPRM, NUCLEBRÁS, Empresas de Mineração). Assim, ẻ natu ral que o seu conhecimento geológico seja o mais polemizado do Nordeste e disponha de documentação farta e inesgotảvel.

A individualização como unidade geotectônica proposta por SUSZCZYNSKI (1966), tem sido seguida com poucas modificações por vários autores como SIQUEIRA e MARANHAOO (1971, 1973), SANTOS (1973) MELLO \& MELLO (1974), etc.. As designações de faixas e sistema de dobramentos, para se afastar conotação geotec tônica, adveio com os trabalhos de BRITO NEVES (1975, 1978).

Seu limite leste, marcado pela falha de Picuí, se faz com o nủcleo de gnaisses,migmatitos e granitos do Maciço São José do Campestre-Caldas Brandão. Seu limite ocidental com os terre nos gnáissico-migmatíticos do Maciço do Rio Piranhas é transicio nal/convencional, e difícil de precisar. Ao norte as estruturas são recobertas pela Bacia Potiguar, e ao sul se justapõem colinearmente à zona de cisalhamento da geofratura de Patos.

No interior do sistema é possível identificar três dis tintos compartimentos geotectônicos/paleogeológicos maiores, mais ou menos emparelhados de leste para oeste: faixas de Frei Martinho (porção contínua oriental), Cruzeta (centro-sudoeste) e Angicos- Jucurutú (noroeste), separadas pos altos do embasamento, de Acari e São Vicente, às vezes designados de "zonas geoanticlinais" (SAN TOS, 1973; BRITO NEVES, 1975).

O embasamento do sistema Seridó aflora nas zonas retro mencioandas (e nos maciços delimitantes do sistema)de forma mais ou menos franca, e em alguns outros altos interiores. São típicos terrenos gnäissico-migmatíticos complexos (A) polideformados, e com värias intercalações ou resquícios de rochas ígneas básicas (d, gb, af) äcidas (ortognaisses) e metassedimentos (1eptinitos, $1 p$, quartzitos, qz). Processos de granitização, introdução de fases graniticas mais jovens, afetam com frequência os típicos terrenos de alto grau do embasamento, chamado de Complexo Caicó/Complexo São Vicente, "Sẻrie Prë-Cearä", etc. 
As dificuldades de separação deste embasamento das se quências metassedimentares, devido aos processos magmáticos e es truturais sobrepostos é uma constatação muito antiga(H. EBERT) e percalço frequente dos mapeamentos geológicos (e do empilhamento estratigräfico) de qualquer escala até os nossos dias.

\section{1 .1 - Lito-estratigrafia}

Deste a primeira coluna proposta por (CRANDAL, 1910), e a partir das colunas propostas por H. EBERT (1955-1969/1970), a polêmica histórica da lito-estratigrafia desta zona se confunde com a própria história da geologia regional do Nordeste. A sínte se do confronto interminável de esquemas foi tentativamente feita inúmeras vezes, como em BRITO NEVES 1973/1975 e DANTAS e CAULA, 1982 .

Os principais trabalhos e mapas geológicos que compõem. a evolução deste conhecimento são os de EBERT (1959-1969/1970), FERREIRA, 1967; FERREIRA e ALBUQUERQUE, 1969; TORRES et a1.,1973; SANTOS, 1973; SIQUEIRA e MARANHÃO, 1973; ANDRITZKY et al., 1974 ; COSTA e HORIKAWA, 1975. Os ültimos trabalhos mencionáveis, reme morando o histörico e reiterando conflitos, são os de LIMA et al., 1980 e JARDIM DE SĀ e SALIM, 1980, cujos esquemas estão confronta dos no Quadro 6.1.

Desde 1955 que se vê circular uma dezena de nomes em posições e conceitos diferentes em colunas diferentes. Há colunas que se confrontam diametralmente. Só a Unidade Seridó (mais ele vada na coluna) permanece sempre na mesma posição estratigräfica, malgrado incorporações e segregações de sua secção inferior.Autên tica ciranda de colunas, nomes e unidades litológicas, tem persistido a repetições de mapeamentos geológicos na escala de de ta1he, tão comuns no Seridó.

Pode-se inferir as causas destas dissenções à partir de algumas características inerentes (geológicas) ao Seridó:

a) Muitas recorrências de unidades litológicas, calcáa rios, cảlcio-silicäticas, quartzitos, usualmente utilizadas como horizontes-guias. Afora o que devem ser mencionadas repetições por redobramento destas litologias e suas variações de fäcies e 


\section{Projeto Scheelita do Seridó - LIMA,E.A.M. et alii, 1980}

\section{ROCHAS FILONIANAS}

Diques de quartzo, quartzo-feldspático, granitos,pegmatitos

Diabásio e basaltos,cálcio-silicáticas anfibolitos.

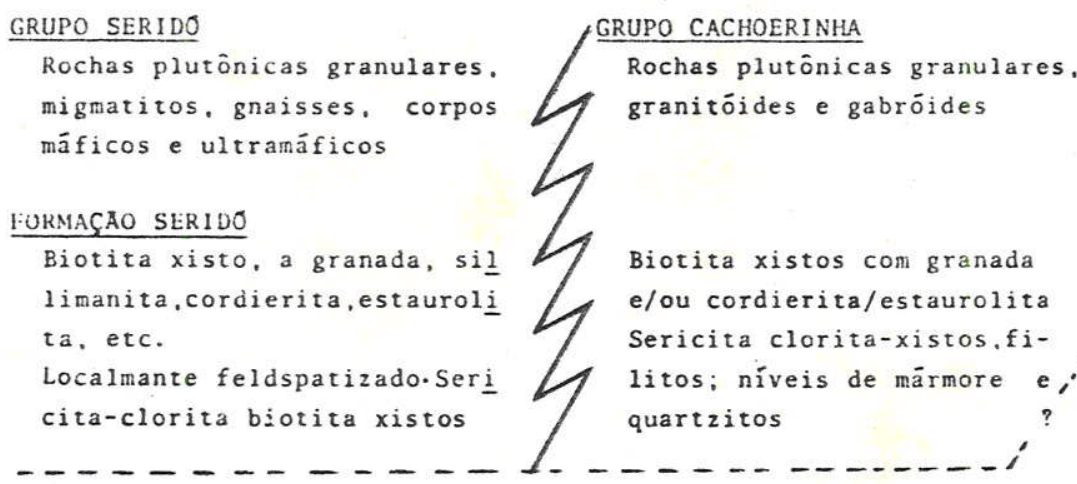

\section{Formaço JUCURUTO}

Biotita-gnaisse epidotífero, biotita e/ou hornblenda gnaisses,10calmente migmatizados.

Incluem: leptinitos, níveis de märmores, calcio-silicáticas mineralizadas (scheelita) e anfibolitos

\section{FORMAÇAO EQUADOR}

Muscovita quartzitos com facies arcoseanas, itabiritos, metaconglomerados oligo a polimictico, com matriz variada, arcoseana,cal cio-silicática, ferrífera ou metapelítica (Parelhas)

COMPLEXO GNAISSICO-MIGMATITICO

Gnalsses o migmatizos en geral: gnaisses facoidais, quartzo-felds päticos, leptinitos, anfibolitos.

Cranitöides: granitos, granodioritos, tonalitos, etc.

liabröides: dioritos e gabros.

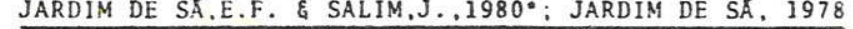

ROCHAS GRANITOIDES (GI a G4) diversificadas e "stockworks" tardios de aplitos e pegmatitos

\section{UNIDADE 3 ("SERIDO")}

Biotita e Muscovita biotita xistos a granada e/ou cordierita predominantes; às vezes com andaluzita, sillimanita e estaurolita. Sericita e clorita xistos ocorrem a oeste de Acari ("Cruzeta")

Intercalaçōes finas, próximas à base de cálcio-silicáticas, anfibolitos, quartzitos e paragnaisses quartzo feldspáticos, conglomerados ou lentes, localmente.

\section{Contato em parte gradacional}

\section{UnIDADE 2 ("EQUADOR")}

Quartzitos (Equador, Feiticeiro, Sāo José Seridó, Florânia) puros e arcoseanos, a muscovita. Gradam para o topo a xistos e gnaisses com epídoto. No topo ou base aparecem metaconglomerados polimícticos (Parelhas,Ouro Branco). Intercalaçōes conglomeráticas.

Biotita xistos,mármores e cálcio-silicáticas e paranfí bolitos aparecem no topo.

\section{UNIDADE 1 ("JUCURUTO)}

Paragnaisses quartzo-feldspāticos, biotita e hornblenda gnaisses. gnaisses a epidoto e meta-arcóseos. Intercalaçōes e gradaçōes para quartzitos,calcio-silicáticas. mármores,xistos, anfibolitos, cālcio-xistos e presença de ortoanfibolitos e tremolita-actinolita xistos.

Fenōmenos de granitizaçāo comum(migmatitos, augen-gnaisses e anatexia(ígneas com xenólitos dos metassedimentos).

COMPLEXO CAICO

Gnaisses, migmatitos, arqueanos prē-deformados (evento $F_{1} M_{1}$ ).

Dificuldade de identificação pela granitização dos contatos $\left(\mathrm{C}_{1}\right)$.

-("empilhamento geométrico-estrutural"). 
possanças.

b) O conhecimento estrutural e geotectônico regional não têm sido considerado devidamente. 0 empilhamento das últi mas feições geomētrico-estrutural assumida pelos estratos é gera mente proposto como coluna lito-estratigräfica. As condições geo tectônicas/paleogeogräficas de mobilidade admitidas em geral no Seridỏ ("geossinclíneo", "cinturão móvel") não pode se coadunar com a formulação de uma coluna lito-estratigräfica ünica e abran gente de todas subdivisões (geotectônicas, paleogeográficas) esperáveis, com ordenação plano paralela de suas unidades.

c) A dificuldade de precisar o limite embasamento-su pracrustais, face aos problemas de mobilização (estrutural, migma tização) conjunta, em diversos setores, e ausência de limites discordantes inquestionāveis.

$\mathrm{Na}$ verdade, hả outros problemas (não geológicos) em jo go. A prë-fixação de esquemas 1ito-estratigräficos (subjugando a verdade estrutural da ärea), a intolerância com esquemas preexisten tes, a falta de diảlogo entre proponentes de um trabalho e outro, a vontade de consignar presença numa polêmica de tanta repercus são, etc.

Muitas alternativas de conciliação entre esquemas fo ram negligenciadas em favor da proposição de outro esquema. Sobre esquemas propostos no Quadro 6.1 aparentemente tão conflitantes, há uma proposição de SANTOS, 1981, bem fundamentada, que admite conciliação. A Unidade Equador (sedimentação nerítica, espessa e praticamente restrita à faixa oriental) teria passagem lateral de fácies para a Unidade Jucurutū para oeste, onde predomina (na zo na oriental os trechos mapeados como Jucurutú são sempre duvidosos), com ocorrências de quartzitos subordinados.

O mapa geológico anexo adotou a coluna proposta por JARDIM DE SĂ e SALIM, 1980 (pe1o conhecimento e exame crítico dos trabalhos anteriores, inclusive o de LIMA et al.,1980 e pela atenção dispensada à componente geolögia estrutural), mas deixa em aber to a possibilidade de composição "Equador/Jucurutü". E como fenô menos de migmatização podem atingir indistintamente toda a coluna , indica-se esta alternativa (A ?), localmente jā comprovada. 
As colunas lito-estratigräficas propostas e confronta das (Quadro 6.1), na sua abrangência, se aproximam de"assemblëias tectono-estratigräficas" ou "macroritmos deposicionais". Um refi namento lito-estratigráfico, em termos do Cödigo de Nomenclatura, ainda terá que ser feito, com a maturação dos conhecimentos atẻ ho je armazenados, respeitando as feiçöes metamörficas e estruturais sobrepostas.

As primeiras "unidades" (pode ser uma ünica e ampla se quência) retratam fases deposicionais terrígenas, essencialmente psamiticas (localmente psefítica) com muitas gradaçöes laterais e verticais para termos peliticos, cálcio-pelíticos, carbonāticos, etc. A contribuição ignea é reconhecidamente importante cortoanfi bolitos, "b.i.f.", etc.) em alguns locais, e a remobilização posté rior, estrutural e migmatitica bem mais efetiva.

A sequência terrigena superior ("Serido") de reconheci mento unânime, prograda de forma irrestrita sobre as anteriores e sobre os altos internos e externos do sistema, com predomínio de sedimentação pelítica. Mas tambēm com variações de fäcies, inte calações cálcio-silicāticas, carbonäticas e psamiticas, etc., 1o calmente. Corresponde a um estägio de amplificação lateral e ve tical dos sítios deposicionais, e muitas variaçōes de litossomas podem ser identificadas. A feição metamörfica e estrutural ("mica xistos") predominante adquirida empana subdivisões faciológicas e estruturais possiveis na escala de detalhe lito-estratigräfico,que são objeto de tantas dissenções nas unidades inferiores.

Uma diferenciação de metamorfismo (mais que lito-estratigräfica) tem sido evidenciada por värios autores na faixa de Cru zeta - sericita-clorita xistós, metassiltitos - do "Grupo Cachoei rinha" ou "Formação Cruzeta", destacado no mapa anexo.

\section{1 .2 - Tectônica e Metamorfismo}

O dobramento regional do sistema serido $\vec{e}$ marcadamente linear, apesar de um desenvolvimento polifảsico que começou a ser clarificado. a partir do trabalho de RIES e SHACKLETON, 1977. Ape nas nos altos interiores do sistema e nos maciços adjacentes a es truturação é mais complexa, com padrões de redobramento em algumas äreas, manteadas por supracrustais. 
JARDIM DE SA (1978a, 1978b) refere-se a presença de uma trama antiga $\left(\mathrm{F}_{1} \mathrm{M}_{1}\right)$ preservada apenas nas rochas de alto grau do embasamento, com transposição generalizada, dobras intrafoliais, fo liaçōes e lineações dobradas por eventos tardios (relativos às sú pracrustais), e padrões de interferência de värias composições; domos e bacias são observäveis na borda leste do Maciço Rio Piranhas.

o primeiro evento tectono-metamörfico das supracrustais desenvolveu dobras fechadas e isoclinais, invertidas à recumbentes, evoluindo at $\vec{e}$ intrafoliais, de grande penetratividade regional ( $F_{2}$ $\mathrm{M}_{2}$ ). O metamorfismo associado $\overrightarrow{\mathrm{e}}$ de fácies anfibolito (granada, sil limanita, etc.) capaz geralmente de produzir fenômenos de graniti zação, no contato embasamento/cobertura.

o segundo evento, relativo às supracrustais $\left(\mathrm{F}_{3} / \mathrm{M}_{3}\right)$ cor responde às dobras maiores, desenhadas pela foliação $\mathrm{S}_{2}$, com plano axial de forte mergulho, e apresentadas neste e na maioria dos ma pas da ärea. São dobramentos longilíneos, paralelos com eixos sub

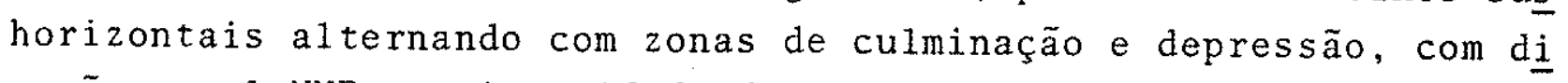
reção geral $\mathrm{NNE}$, e xistosidade $\left(\mathrm{S}_{3}\right)$ de sericita-clorita-biotita. metamorfismo $\left(M_{3}\right)$ produz retrometamorfismo local (JARDIM DE SA, $1978 \mathrm{a}, 1978 \mathrm{~b})$, mas hä predomínio da fäcies anfibolito, e associa ção muito importante com os granitöides regionais. LIMA et al., 1980 indicam vergência regional deste dobramento no sentido do Ma ciço Rio Piranhas (para oeste).

Fases tardias e restritas de deformação $\left(\mathrm{F}_{4} / \mathrm{M}_{4}\right)$ incluem crenulação, formação de "kinks", zonas de cisalhamento, etc. 0 me tamorfismo ẻ definido como retrögado, de fäcies xisto verde, e su bordinado.

o dobramento de xistosidade principal $\left(\mathrm{F}_{3} / \mathrm{M}_{3}\right)$ ao sul do sistema acha-se envolvido no cisalhamento dextral do lineamento de Patos (considerando sin a pös $-F_{3}$ ), conferindo a forma sigmöide des ta parte norte do domínio central.

\section{1 .3 - Magmatismo Granitico}

No Serido e maciços adjacentes se verifica diversifica do plutonismo granitico, de pequeno, médio e grande porte, tentati vamente sistematizados por diversos autores. 
Pelo menos quatro grandes grupos podem ser descritos na escala de reconhecimento, considerando o tipo de relação com as fa ses de deformação regionais.

a) Augen gnaisses, granito-gnaisses, granitos estratói des e migmatitos são identificados no embasamento do Sistema Seri dó, anteriores (prê-tectônicos) as fases de deformação presentes nas supracrustais, Estas rochas graniticas e alguns corpos bâs cos dificilmente têm sido destacados cartograficanente do contexto do embasamento.

b) Granitos e granodioritos dos grandes batólitos, sem pre associados com fragmentos e porções de rochas mäficas (Acari, Patu, Catole do Rocha, $\lambda_{2}$ ). Apresentam gnaissificação na matriz (sintectônicos) e blastese feldspätica raramente orientada. E ainda a presença de granodioritos e monzogranitos intrusivos, contendo enclaves de mäficos, sugerindo tratar-se de suite granitica do "tipo I", dada sua estreita relação com material ígneo mäfico pri märio.

c) Granitos de filiação migmatítica com enclaves de me tassedimentos e gnaisses do embasamento, associadas à estruturas reviradas, de baixo ângulo (sintectônicas, $\lambda_{2}$ ). E tambëm leucogra nitos intrusivos, equigranulares ou fracamente porfiróide (Acauã, Cerro Corá, etc.), que podem ser em maior parte do "tipo S" (SAN TOS e MELO, 1978 ).

d) Granitos alcalinos, granitos equigranulares röseos filonianos ("tipo Itapetim"), leucogranitos, granitos pegmatitöides (Picuí-Pedra Lavrada), pegmatitos e vieiros, todos com nítida conotação pös-tectônica $\left(\lambda_{3}\right)$.

A visão da escala de reconhecimento, antevista

por ALMEIDA et al., 1967 (tipos "Conceição" - "Itaporanga" - Itapetim"), permanece välida, de certa forma, ainda que tenha acrescido muito - número de informações (estruturais, petrolögicas) e a cataloga ção de novos tipos. Em especial, os trabalhos de SANTOS e MELO (1978), SANTOS, E.J. (1980) e JARDIM DE SÄ et aI., 1981 devem ser mencionados, como referências obrigatörias para detalhamentos. 


\section{1 .4 - Mineralizações (Sinopse)}

O Sistema do Seridó respalda com suficiência a sua vas ta bibliografia, em grande parte voltada para seus recursos econô micos, cuja descrição escapa aos objetivos presentes.

o recurso mais importante do Seridó ê a scheelita, com värias minas em exploração, em jazimentos de värios tipos: "skarns" ou tactitos (90: dos depösitos), associados à anfibolitos, a mäfi cas e ultramáficas, filonianos, etc. A reserva total de minērio de tungstênio é superior a 144 milhões de toneladas, segundo LIMA et al., 1980 .

Tambëm o Serido sedia uma província pegmatítifera com cerca de 700 pegmatitos mineralizados, situados numa área elíptica alongada segundo a faixa oriental (15 $\left.000 \mathrm{~km}^{2}\right)$ do sistema, sendo berilio, tantalita-columbita, cassiterita e caulim os principais recursos explorados, ao lado de vários outros subordinados.

Merecem menção no sistema outros recursos minerais, co mo urânio (associado à granitos tardios) e jazimentos metamōrfí cos de origem sedimentar (itabiritos, quartzitos, märmores, etc.).

\section{2 - 0 SISTEMA DE DOBRAMENTOS PIANCO-ALTO BRIGIDA}

- Sistema de Dobramentos Piancó-Alto Brígida, na con cepção original de BRITO NEVES, 1975, situa-se ao sul do lineameñ to de Patos e ao norte do eixo de rochas gnáissicas-migmatiticas e graniticas de Teixeira-Serra Talhada ("Zona Geoanticlinal de Teixeira"), assumindo forma triangular imposta pela tectônica bra sileira, com uma ärea pröxima de $40000 \mathrm{~km}^{2}$.

Ao norte, sua zona de delimitação com o Sistema Seridó é perlongado por uma faixa estreita de migmatitos (provavelmente do embasamento) extremamente deformados. Para o sul, parece bas tante provável a ligação do seu contingente lito-estratigräfico com aquele do Sistema Riacho do Pontal, uma vez que os deslocamen tos direcionais ali promovidos pelo lineamento Pernambuco são bas tante modestos.

o sistema de dobramento acha-se caracteristicamenre con 
dicionado pelo arranjo de falhas policiclicas, externas (Patos, Per nambuco) e internas. Observa-se duas faixas mais ou menos distin tas, sinformais, condicionado por estes falhamentos. Ao norte, tem- se estruturação próxima a E-W, comandada por um feixe de falhas oriundas do lineamento de Patos, desde o açude de Curemas. Após uma zona tectônica mais elevada ("alto de Piancō") observa-se ao sul outra faixa de dobramentos acompanhando uma sêrie de geofratu ras de direção NE e ENE (a maior parte de tipo Sinistral). De for ma que a reconstituição paleogeogräfica/geotectônica do sistema ë muito difícil, pelo condicionamento tectônico que lhe foi imposto, em várias etapas.

Este sistema conta com vários mapeamentos nas escalas $1 / 100.000$ e 1/50.000, oriundos da SUDENE (Projeto Gipsita, Projeto Ferro e Manganês, etc.), do DNPM-SUDENE (fases preliminares do Pro jeto Cobre) e do Curso de Geologia do Recife (relatórios de gradua ção, 1976 e 1980-1982), afora muitos prospectos locais de compa nhias de mineração. A integração apresentada por O. BARBOSA, 1970 (trabalho realizado ate 1964 ) tem sido repetida com frequência em todos os mapas de pequena escala da região, e é praticamente o fun damento de todas sinteses já escritas.

O embasamento do sistema só se expōe fracamente nos seus flancos. Ao norte, na borda do Maciço Rio Piranhas predominam ro chas migmatiticas e rochas granulares de paleossoma bäsico (diorí tos, quartzo dioritos) a intermediäria, cataclasados e milonitiza dos, ao longo da zona arqueada situada entre as falhas de Malta e Patos. Ao sul, ao longo da "Zona geoanticlinal de Teixeira" predo minam gnaisses graniticos e migmatitos circunscrevendo autênticos batölitos sincinemäticos.

As demais indicações de rochas do embasamento (A), de Piancó, sul de Ouricuri, sul de Salgueiro, entre outras tem sido postas em dúvida em mapeamentos recentes (BEURLEN et al., 1978; BRITO NEVES et al., 1982), e colocadas como litofácies psamíticas imaturas das sequências supracrustais. Desta forma a delimitação real e a extensão do sistema em anälise podem vir a ser consideravelmente ampliadas, com novos mapeamentos de detalhe ou semi-deta the, como os que estão em progresso atualmente pelo Curso de Geolo gia do Recife/Convênio Minérios de Pernambuco e pela CPRM/Convênio DNPM. 


\section{2 .1 - Lito-Estratigrafia}

No Sistema Piancó-Alto Brígida, de certa forma ao con trário do que aconteceu na terminologia do Seridó, um variadíssi mo contexto sedimentar e vulcano-sedimentar primärio, tem sido ne gligenciado em favor de feiçōes macroscöpicas uniformizadoras do metamorfismo regional. Assim se tem uma grande quantidade de ter mos litológicos primärios, variadós em feição e origem, e uma par cimônia de designações lito-estratigräficas (Grupos "Salgueiro" e "Cachoeirinha") voltadas para feições de metamorfismo, classifica das na escala de reconhecimento.

Pela ordem, os trabalhos P. VEIGA $(1966,1968)$, J. P. SANTOS (1967), A.L. CALDASSO (1967), TEIXEIRA et a1.,(1965), ALBU QUERQUE (1970) e BARBOSA et al. (1964-1970), entre outros discut ram as grandes linhas 1ito-estratigräficas do sistema. Quartzitos basais, micāceos, foram identificados quase na maioria dos per fis, seguidos de biotita xisto granaditero (espessuras modestas), e importante pacote de filitos e sericita-clorita xistos, loca 1 mente com intercalações ou lentes quartziticas, itabiriticas, ca1 cärias, e mais raramente conglomeräticas. Desta ëpoca, apenas CALDASSO, 1967 mostrou gradação primäria de psamitos imaturos na base para os meta-pelitos dominantes e característicos da unidade. As referências à contribuiçōes vulcanogênicas foram muito escassas até então.

o Projeto Cobre, 1iderado por 0. BARBOSA (1964-1970) in fluenciou decisivamente a terminologia lito-estratigräfica,quando designou informalmente: a) Grupo Salgueiro "composto por biotita-xistos, xistos a duas micas e quartzitos..." e b) Grupo Cachoe $\underline{i}$ rinha com "xistos menos metamörficos que os do Grupo Salgueiro, constam de micaxistos finos, filitos, clorita-xistos, anfibolitos, itabiritos e quartzitos prateados". Apesar de nomeadas informal mente e de se insistir no caräter transicional ("difíceis de pre cisar") dos contatos, estas designações pioneiras foram consagra das em vārios mapas e trabalhos cientificos subsequentes.

Somente a partir do trabalho de BEURLEN et a1., 1978, se começou a enfatizar a grande variedade de litologias primärias,ple namente cartografáveis em semi-detalhe, clästicos mëdios imaturos, 
clästicos finos e unidades vulcanogênicas, compondo diversas se quências. Como tambëm se destacou, a partir daí, a necessidade de rever os conceitos terminolögicos vigentes e a posição/natureza dos contatos "Cachoeirinha-Salgueiro-Uauä" (embasamento).

Na zona a leste de Piancó, BEURLEN et al. (op.cit.)iden ficaram:

a) Biotita xistos granadiferos, muscovita xistos e gnaisses com intercalações carbonäticas existosas $\left(B_{1}\right)$, micaxistos migmatizados $\left(B_{2}\right)$, na infra-estrutura das sequências de cobertura.

b) Clorita-sericita xistos, quartzitos e filitos $\left(\mathrm{C}_{1}\right)$ com contatos gradacionais com unidades basais.

c) Passagem de gnaisses arcoseanos e xistos (de $B_{1}$ ) pa ra filitos, metassiltitos, grauvacas, quartzitos, com leitos (e diques) de metavulcânicas, de espessuras centimétricas a decimê tricas (anfiboliticas, dioríticas, gäbricas) - $\left(\mathrm{C}_{2}\right)$.

d) Auréolas extensas de termo-metamorfitos, a sillimani ta-granada-estaurolita e biotita,nas adjacências dos inúmeros "stocks" graniticos da faixa.

COSTA, 1980, estudou particularmente a faixa norte do sistema, descrevendo duas associações litológicas principais:

a) Uma associação de rochas vulcânicas representadas por dacitos, andesitos, piroclásticas, com intercalações de cherts hematiticos e piritosos, grauvacas e folhelhos.

b) Uma sequência sedimentar pelitica e psamítica, com termos mais grosseiros (grauvacas e conglomerados polimicticos) compostos por diversos tipos litolögicos, inclusive cherts, vulcâa nicas, etc.

MUNIZ e SANTOS, 1980 , no estudo do conjunto do sistema, identificaram três faciologias predominantes: psamítico-pelítica, pelitica e vulcanogênica. As primeiras de distribuição generali zadas (como jä descritas), onde parecem raros os metassedimentos de origem química e orgânica, e sempre há evidências de um ambien te deposicional instāvel e com certo grau de turbulência. As uni dades vulcanogênicas distribuem-se em äreas restritas e estão as 
sociadas de certa forma a centros de instalação de "stocks" dior ticos-tonaliticos-granodioriticos, sendo o vulcanismo de natureza andesitica-traquitica-dacítica, incluindo lavas, piroclästicos e tufos.

$\mathrm{Na}$ falha de Salgueiro BRITO NEVES et al. (1982) identi ficaram e mapearam associações semelhantes, utilizando designações informais locais. Cabe destacar, ao sul de Salgueiro (PE-460) a presença de paragnaisses arcoseanos ("gnaisse da Serra das Vassou ras") em espesso pacote e sua interlaminação com biotita xistos nas zonas de contato. Comumente, em mapeamentos regionais estes gnaisses ("Grupo Uauā") têm sido colocados no embasamento. Prati camente toda zona de contato "Salgueiro-Cachoeirinha" do Projeto Cobre mostrou-se inconsistente, quando da cartografia geológica de detalhe.

Em sintese, no Sistema Piancó-Alto Brígida, as sequên cias supracrustais representam värias associações vulcano-sedimen tares e sedimentares peliticas-psamiticas, com termos psamíticos imaturos e químicos subordinados. O metamorfismo regional é na fäcies xisto verde, com intensificações locais (granada-biotitaxistos, micaxistos pegmatítizados). 0 desenvolvimento lito-estra tigräfico do sistema è complexo e variado, e conhecido a nível exploratório apenas. As designações de "Grupo Cachoeirinha/"Gru-

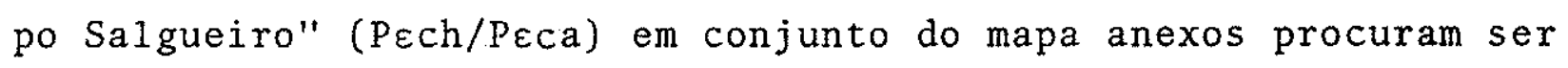
abrangentes e acatar provisoriamente o histórico de terminologia regional. Qualquer das designações isoladas é inadequada e não recomendável, e ambas estão fadadas a revisão em curto prazo.

Resta mencionar a presença de um pequeno testemunho de sedimentos semelhantes aos do Grupo Jaibaras, na fossa de Iara $(\varepsilon O i)$ pouco ao norte da cidade de Barro (CE), sobre a projeção ocidental do lineamento Patos. Nesta "bacia", o preenchimento é essencialmente detrítico e imaturo, sendo constituido por areni tos arcoseanos, arenitos conglomeräticos, conglomerados e brechas polimicticas. Associam-se, menos comumente, siltitos arenosos de estratificação cruzada. As camadas dispõem-se com fraco mergulho e levemente onduladas. São rochas muito fraturadas, com espelhos 
de fraturas esverdeados pela presença de carbonato de cobre. Tra ta-se de uma relíquia de sitio deposicional mais extenso.

\section{2 .2 - Tectônica e Metamorfismo}

Para a sistematização do tectonismo do Sistema Piancö-Alto Brígida são necessārios ainda muitos trabalhos específicos. A dificuldade de sintetizar o aspecto estrutural è devido a gran de extensão da ärea, com diferentes padrões de deformação de um setor a outro, a ação dos falhamentos profundos, a frequência da circunscrição de corpos ígneos importantes, e a ductibilidade de suas rochas. Por outro lado, em um mesmo perfil pode ser consta tadas diferenças marcantes entre o padrão exibido por rochas da in fra e supra-estrutura.

Por toda extensa ärea de exposição destes metassedimen tos, via de regra, se trabalha com dobras de foliação. Hä evidên cias de uma fase de deformação inicial $\left(D_{1}\right)$, em grande parte isó clinal, cuja foliação descreve dobramentos simêtricos e assimê tricos $\left(D_{2}\right)$ de direção E-W (faixa norte), NE (maior parte do sis tema) e WNW-ESE (sul de Salgueiro). Apesar da transposição fré quente, é porēm possîvel ver na meso-estrutura värias feições sé dimentares e vulcano-sedimentares, onde o baixo metamorfismo re gional o permite.

A continuidade dos dobramentos de foliação $\vec{e}$ muito pre judicada pelos inümeros corpos intrusivos (e suas auréolas) e pela ação da densa rede de falhamentos. Localmente se observa encurva mento significativo nos eixos das dobras $\left(D_{2}\right)$ comandadas por de formações sobrepostas $\left(\mathrm{D}_{3}\right)$ como a leste de Piancó, e mesmo caso de culminações e depressões comandadas por redobramento quase or togonal. A sul e sudeste de Salgueiro são observados padrões de redobramento de tipo domo e bacia, com antiformes e sinformes sub circulares e elípticos em sërie.

Alēm do que, crenulações, clivagens de fraturas, "kinks", zonas cisalhadas, etc. são feições locais $\left(D_{4}\right)$, mas frequentes. Mas, de uma maneira geral, falta conhecer melhor a ordenação de espaço e tempo de todos esses padrões estruturais, e a sua rela ção com o metamorfismo regional. 
As observações sobre o metamorfismo regional do sistema em anälise são superficiais em geral, em termos de tipologia bảs ca e fases evolutivas. Predomina metamorfismo na fäcies xisto verde, diversas subfäcies, com variações locais a transição xisto verde-anfibolito e anfibolito.

o aparecimento da fảcies anfibolito em metapelitos (quart zo-microclina-biotita-almandina-muscovita) invariavelmente foi responsāvel pela edição inadequada de designações lito-estratigräficas fora do termo "Cachoeirinha", sempre vinculado a fácies xis to verde.

A intromissão frequente de corpos ígneos nos metassedi mentos é acompanhada por formação de extensas auréolas de metamor fismo termal (raramente mapeados) de intensidade variävel, até fäcies hornblenda hornfels. A leste de Piancó,BEURLEN, et al., 1978, descrevem paragêneses ricas em granada, andalusita, sillima nita e estaurolita. Metamorfismo dinâmico, cataclästico, é comum acompanhando linearmente a densa trama de falhamentos expostos em mapa.

Nas rochas gnäissicas ("Serra das Vassouras") é muito comum o aparecimento de fảcies migmatiticas, o que levou tantos au tores a separä-las como parte de "embasamento". Nas rochas meta-peliticas (de ardósias a micaxistos) e meta-basiticas ( tremoli ta-actinolita xistos, tremolita-clorita-actinolita xistos, clori ta-epidoto xistos) è possivel avaliar melhor as características do metamorfismo regional plurifacial desta ampla e variada sequên cia. O avanço para uma classificação lito-estratigráfica tem que enfrentar primeiro as feições metamórficas. deixando de lado a ter minologia vigente, e isto é uma meta viāvel em escalas 1/100.000 e superiores.

\section{2 .3 - Magmatismo Granitico}

O Sistema Piancó-Alto Brígida encerra o mais intenso e variado cortejo de rochas graniticas do Nordeste, sendo a locali dade típica por excelência de todas as propostas de sistematiza ção do problema, como ALMEIDA et al., 1967, BRITO NEVES e PESSOA, 1974 e SANTOS e MELO, 1978. Além das manifestações migmatíticas sinsedimentares discutidas, destaca-se em mapa de qualquer escala 
à expressividade do plutonismo granítico.

o plutonismo granítico apresenta grande diversidade de fácies e natureza de contato, de acordo com o ambiente de formação e a seç̧ão exposta. Destaca-se primeiramente o grande número de "stocks" e batölitos (tipo "Conceição") de composição granodioriti ca, quartzo-dioritica, tonalítica, etc. com pórfiros de plagiocla sio, orientação suave nos bordos, e frequentemente enclaves de ro chas mäficas. Os contatos são em maior parte intmusivos (supra-estru tura), e em parte gradacionais. O nümero de enclaves mäficos (ga bróides, dioríticos) é tão frequente e característico que SANTOS e MELO, 1978, admitem a preexistência de um substrato mäfico.

Rochas graníticas porfiriticas, a microclina (tipo "Ita poranga"), com ou sem coroa de plagioclásio são típicas desta ārea. Ha alguns exemplos de extrema feldspatização, alcançando-se composições quartzo-sieniticas. Estes granitos tambëm mostram contatos bruscos (metapelitos) ou gradativos (gnaisses, xistos migmatizados) com as encaixantes, e variações de fäcies para o tipo anteriormen te descrito. De modo que a concorrência no mesmo maciço das assó ciações "diorito-granito-porfiröide" e "tonalito-granito",proposto por SANTOS e MELO, 1978, pode ser confirmada com vários exemplos.

o corpo sienitico de Catingueira (a sudoeste de Patos) representa outro tipo de associação (alcaligranito-sienito) muito comum do Nordeste e de outras localidades da faixa (Terra Nova). Sua composição modal varia bastante de quartzo-monzonito até sie no-granito.

Corpos de dunitos e piroxênitos serpentinizados são co nhecidos ao sul de Catingueira (com mineralização niquelíferas), e outros complexos de rochas mäficas de carāter sintectônico são descritos por BEURLEN et a1., 1978.

Afora estes corpos maiores, cartografāveis $\left(\lambda_{3}, \lambda_{2}, s i\right)$ por toda área devem ser mencionados inümeros enxames de diques gra niticos, quartzo-sieniticos e sieniticos, e mesmo pequenos "stocks" que cortam inclusive as rochas magmáticas previamente descritas. Por exemplo, na ārea entre Teixeira e Serra Talhada, em Salgueiro, a sul e sudoeste de Salgueiro, etc. estão os tipos mais proeminen tes, que podem ser convenientemente representados na escala do ma pa anexo. 


\section{3 - O SISTEMA DE DOBRAMENTOS RIACHO DO PONTAL}

A porção sul do domínio central de Borborema recebeu a denominação original dé faixa de dobramentos, enriquecido e modi ficado pelo trabalho de ALMEIDA, 1977 e a síntese de SANTOS e CAL DASSO, 1978. A definição da seus limites demanda muitas investiga ções geológicas ainda.

Para o norte, a conexão com o Sistema Piancó-Alto Brígí da jä mencionada, é clarividente em qualquer escala. Para oeste e sudoeste o tipo de vinculação com o Sistema de Dobramentos do Rio Preto (INDA e BARBOSA, 1978) não è conhecido, em vista de cá peamento cenozóico, a oeste do Rio São Francisco. Hā indicações preliminares de uma composição de faixas, arranjadas no estilo da Sergipana e Sul Alagoana. Para leste, a separação com o Sistema Sergipano se faz por uma projeção arqueada do embasamento, sobre a qual jazem os metassedimentos de Bacia Bonita (Pebb), o que deixa em aberto a possibilidade de uma ligação paleogeográfica.

Para o sul, hả identidade inconsútil entre o embasamento desta unidade e a do Craton do São Francisco. A concepção do Iimi te de províncias nesta ārea jă foi abordado (item 3.2), perante da dos estruturais, geocronológicos e geofísicos muito escassos. Tra ta-se de uma delimitação convencional e discutível, encarada ainda como abstração da geotectônica, e não pode haver ainda consenso formado sobre sua posição mais adequada.

A anālise do mapa geológico anexo permite visualizar de imediato uma compartimentação natural, de ordem litológica e estru tural no sistema em anälise:

a) o comportimento sul, com predominio de rochas gnäis sico-migmatíticas (A) do embasamento, e micaxistos (Pعsa(a)), com estruturação N-S, em grande parte dentro do território da Bahia.

b) o compartimento nordeste, com exposiçōes alternadas do embasamento e de metassedimentos do sistema, com estruturação ENE-WSW, ao longo do alto curso de Riacho do Pontal, desde PaulistanaPI .

c) A "Bacia" de Barra Bonita, estrutura sinforma1 NE-SW, implantada sobre rochas do embasamento, e alinhada com o comparti mento nordeste. 
d) O compartimento noroeste, que inclui metapelitos de baixo e mëdio grau (Pesa, Pesa ${ }_{1}$ ), värios corpos graniticos intru sivos, e mostra estruturação NNE-SSW a NE-SW, situada dentro do Estado do Piauí.

A bibliografia versando sobre a área em lide é muito vas ta, estando sintetizada e avaliada no trabalho de SANTOS e CALDAS So, 1978. Os projetos Sudeste do Piauí I e II (CALDASSO, 1973) e Colomi (SOUzA et al., 1979) do Convênio DNPM/CPRM apresentam ma pas de integração (1/250.000 e escalas superiores) da maior parte deste sistema, com excelente suporte de dados geológicos gerais. outros trabalhos específicos serão mencionados quando oportuno.

\section{3 .1 - Embasamento (Maciço Marginal ao Craton do São Francisco)}

As rochas do embasamento do sistema Riacho do Pontal e do Craton do São Francisco se expõem numa área cheia de saliências e reentrâncias, ao longo do mëdio São Francisco (compartimento sul). No passado, estas rochas foram atribuídas ao Grupo Caraiba (0. BARBOSA, 1965) na sua maior parte, tendo SouzA et al., 1979 utilizado a terminologia "Complexo Metamörfico-Migmatitico". Tra tam-se, na realidade, de típicos terrenos de alto grau, de acordo com os requisitos de WINDLEY e BRIGDWATER, 1971.

Hả predominância de complexos migmatiticos (diatexiti $\cos$ e metatexiticos), de estrutura variada, contendo enclaves, len tes, niveis e massas disformes de rochas básicas e ultrabásicas. os gnaisses são de värios tipos, biotita (muscovita) gnaisses, gnaisses graniticos, gnaisses quartzo-feldspāticos com interlami nações anfibolíticas, e mais restritamente augen gnaisses. Desta cam-se deste contexto, pelo aspecto litológico e feição topogräfi ca, estreitas e descontínuas bandas e faixas quartziticas,cálcio-silicatadas (diopsídio, epídoto) e máfico-ultramáficas (anfiboli tos, xistos a tremolita e actinolita, metahornblenditos), parte apenas assinalävel nos mapas geológicos.

Fäcies de metamorfismo anfibolito alto é comum, e com

passagens locais a granulito. Hả ocorrências subordinadas e cir cunstanciais de retrogressão à fäcies xisto verde. 
Predominam estruturas submeridionais NS a NNE-SSW, mas não hä linearidade marcante nos traços de foliação, sendo possível discernir várias terminações periclinais e sinuosidade destes tra ços, que refletem um quadro final de sobreposição de värias fases/ /eventos de deformação (mínimo de duas fases antigas).

As rochas graniticas $\left(\lambda_{1}\right)$ constituem diversos corpos ("stocks" e batolitos) alongados, de foliação incipiente, e de com posição (granitos, adamelitos, granodioritos) e textura (média a grosseira) variāveis, às vezes preservando caracteres de intrusivas. os dados geocronológicos disponíveis apontam idades do Proterozöico Inferior para estas rochas, e idade Arqueano para suas encaixantes.

A Unidade Colomi - Complexo Colomi de SoUzA et al.,1979 reủne uma sequência de rochas metacarbonatadas ("Caste10"), forma ções ferriferas ("Serra da Capivara") e metaclásticos imaturos ("Serra da Bicuda"). Configura restos dispersos de uma cobertura intracratônica dobrada, provavelmente do Proterozóico Inferior, dis cordante sobre o embasamento.

\section{3 .2 - Lito-Estratigrafia e Aspectos Petrogräficos}

As unidades lito-estratigräficas individualizadas no Sis tema Riacho do Pontal guardam analogias estreitas com aquelas do sistema vizinho a norte.

A unidade de paragnaisses e quartzitos, Rajada (PEsa(r)) se expõe preferencialmente nos núcleos antiformais do compartimento nordeste. Predominam gnaisses claros a muscovita, gnaisses a bio titas, ricos em feldspato (metarcóseos muscovíticos), bastante la minados e com desenvolvimento frequente de estruturas migmatiticas. Mostram também fảcies quartzosas e gradações para quartzitos. Hả possibilidades que os quartzitos que orlam a dorsal de Ponta da Serra (compartimento sul) façam parte deste contexto, que segundo SA e SOBRINHO, 1979 é bem mais extenso para sudoeste da faixa("Com plexo Serra Dois Irmãos Cavaleiro"), e assenta em discordância tec tônica e erosiva sobre o embasamento (A).

os metapsamitos do norte de Afrânio(qz) incluem quartzi tos, quartzo-xistos, biotita-muscovita-clorita xistos e filitos quartzosos. Em contato gradacional com estas rochas aparecem os 
xistos verdes de Monte Orebe (Pعsa(mo)), contendo xistos anfibolí ticos, intercalações de quartzitos com anfibólio e diopsídio ( de $\underline{s}$ critos por SIQUEIRA FILHO, 1967), com características genéricas de uma sequência vulcano-sedimentar.

A unidade de micaxistos e filitos (PEsa e PEsa $s_{1}$ ) - "Mica xistos de Afrânio" - foi chamada de "Grupo Salgueiro" por BARBosA, 1965, e de "Complexo Casa Nova", por SouzA et a1., 1979. Ela ocor re nas estruturas sinformes do compartimento nordeste, e nos com partimentos sul e noroeste, circunscrevendo a dorsal (perianticlinorial) de Ponta da Serra.

Esta unidade apresenta quartzitos basais, às vezes con glomeráticos, e mesmo intercalações de gnaisses arcoseanos, que passam a biotita xistos e biotita muscovita xistos, frequentemente a granada e estaurolita. Intercalações de mármores e de quartzi tos ocorrem localmente. Fenômenos de migmatização, injeções de dí ques quartzosos e aplíticos são usuais nesta unidade.

No compartimento noroeste, na borda da Bacia do Parnaíba aparece uma unidade (ou gradação para) de filitos, clorita-xistos e quartzo-filitos ( $\mathrm{P} \varepsilon \mathrm{sa}_{1}$ ), em concordância aparente com os micaxis tos (Pعsa), e contornando um núcleo de exposição do embasamento. Intercalações de quartzito, cálcio-filitos e calcârios ("Calcário Vargem Grande") são conhecidos nesta unidade.

Esta porção nordeste do sistema é cortada por maciços bá sico-ultrabásicos (gabro-serpentinito, piroxenito) e várias intru sões graníticas e sieníticas de caráter tardio $\left(\lambda_{3}\right)$.

De uma maneira geral as supracrustais deste sistema mos tram metamorfismo regional, de fäcies anfibolito (micaxistos gran $\underline{i}$ diferos a estaurolita, migmatização local) a fácies xisto verde,em praticamente todos os compartimentos dissertados. Esta constata ção é feita a nível preliminar, e demanda investigações complemen tares sobre o processo evolutivo e zoneamento metamórfico.

No compartimento de Barra Bonita a nordeste de Petrolina jaz uma unidade (PEbb) metapelítica de baixo grau de metamorfismo, discordante sobre o embasamento gnáissico-migmatítico arqueano (BRITO NEVES, 1975). Há alguns níveis descontínuos de metassiltí tos e meta-arenitos finos, e lentes de calcário e câlcio-xistos. 
A unidade de Barra Bonita, acha-se moderadamente dobrada na direção NE-SW, sendo considerado descontínuo o estilo deste do bramento.

o significado desta bacia é contravertido. SoUzA et al., 1979 , atribuem correlação (tectônico-estratigráfica) com o Grupo Estância dos arredores de Curaçā. JARDIM DE SĀ e HACKSPACHER,1980, atribuem correlação plena com os micaxistos de Afrânio ( $P_{\varepsilon} S_{a}(a)$ ), inclusive advogando presença de quatro fases deformacionais $\left(F_{1}, F_{2}\right.$, $\mathrm{F}_{3}, \mathrm{~F}_{4}$ ) neste compartimento.

\section{3 .3 - Compartimentação Tectônica}

A compartimentação tectônica formulada de início para o sistema aponta na realidade quatro distintas zonas (dominâncias) lito-estratigráficas e estruturais mais ou menos bem distintas.

No compartimento sul, como já discutido, predominam dire ções estruturais submeridianas, herdadas do embasamento, e resul tantes da sobreposição de värias fases de formas antigas (Dn).

No compartimento noroeste, e na parte norte da dorsal de Ponta da Serra, a foliação metamórfica das supracrustais mostra uma série de dobras abertas ou fechadas, com plano axial mergulhando para oeste, e eixos com plunge para norte $(D n+1)$. Esta estrutura ção se arrefece ou não aparece representada mais para o interior do compartimento sul (pode ser restrita às supracrustais). Em parte esta estruturação NNE-SSW se acha interceptada pelo cortejo de rochas igneas, próximo da borda da Bacia do Parnaíba.

Mais para o norte, esta estruturação é interceptada pe los falhamentos inversos e dobramentos $(D n+2$ ?) que caracterizam o compartimento nordeste, de Paulistana até a região de Petrolina/ /Barra Bonita. Este compartimento se caracteriza por um sistema de dobras de foliação bastante apertadas e isoclinais, de di reção NE-SW e plunge para nordeste, com planos axiais inclinados para norte e noroeste, caracterizando vergência para sul e sudeste. Esta estruturação vergente para a zona cratônica é acompanhada por falhas inversas e empurrões paralelos (NE-SW) e ladeado por fa thas de rejeito direcional (NW-SE). 
A nive1 de reconhecimento quatro fases deformacionais foram propostas, na escala da região,por JARDIM DE SÃ e HACKSPACHER, 1980. As duas primeiras fases $\left(F_{1}, F_{2}\right)$ são muito antigas e pene trativas regionalmente, e no minimo de idade pré-Chapada Diamant na. A fase $F_{3} .(=D n+1)$ de "trend" N-S deve ser correspondente ao Ciclo Espinhaço. A fase mais jovem $\left(\mathrm{F}_{4}\right)$, considerada corres pondente ao Ciclo Brasiliano, seria efetiva ao norte do paralelo de Afrânio (Dn+2?), mas com influência decrescendo gradativamente daí para o sul. Não hã ainda dados geocronológicos suficientes para ratificar estas primeiras avaliações cronológicas de deforma ção, da zona móvel para o Craton.

\section{4 - SOMULA DOS DADOS GEOCRONOLOGICOS}

O problema de evolução dos sistemas metassedimentares ditos convencionais do Nordeste ainda está em fase preliminar do equacionamento. 0 tipo de terrenos estudados e os resultados ob tidos envolvem temas candentes e da ordem do dia na Geocronolo gia.

Nas condições da fase atual, onde se dispõe de uma maio ria absoluta de dados $\mathrm{K} / \mathrm{Ar} \mathrm{e} \mathrm{Rb} / \mathrm{Sr}$, pode-se assentar alguns pon tos relativamente pacíficos, com base na bibliografia publicada e em vias de publicação. A estas conclusōes preliminares e simples serão contrapostas uma série de questões que permanecem sem res postas.

0 embasamento destes sistemas metassedimentares $\ddot{e}$ segu ramente prë-brasiliano, formado de rochas arqueanas com diferente grau de retrabalhamento. Em parte, estas rochas também foram afe tadas por processos brasilianos.

Para definir a posição no Proterozóico dos eventos de sedimentação e vulcanismo das sequências que preenchem estes sistemas não se dispõe de dados concretos. Hä sugestöes, de diferen tes fontes, baseadas em observações e correlações a longa distân cia, de que estes processos sejam prē-Proterozóico Superior.

A grande massa dos dados K/Ar dos metamorfitos (e de rochas graniticas) se situa no intervalo de 450-660 m.a., com ra ras exceções. Isto assegura a existência de etapas importantes de 
resfriamento regional no Brasiliano, seguinte a soerguimento desnudação erosiva generalizada.

As idades obtidas para intrusivas filonares e pegmati tos, e mesmo para rochas graniticas efetivamente tardias, congre gando diferentes métodos de anälise, são bastante coerentes, e in dicam valores de 450-510 m.a., observação que se ençaixa e comple menta a asserção anterior.

Nos três sistemas analisados hả isócronas de referência para os metamorfitos, muito genëricas, apontando eventos de homo geneização isotópica do estrôncio em intervalos distintos mas pró ximos, da parte final do Proterozöico Superior, entre 560-660 m.a. A margem e acima de algumas considerações necessãrias a serem adu zidas, è clarividente e irrefutävel a submissão dos metamorfitos desses sistemas aos processos tectono-termais brasilianos, a ní vel superior a unidade lito-estratigräfica, afetando drasticamen te a geoquimica do sistema $\mathrm{Rb}-\mathrm{Sr}$.

No Seridó, MCREATH e JARDIM DE SÁ (1979) apresentaram uma isöcrona de $\mathrm{T}=600 \mathrm{~m} . \mathrm{a} ., \mathrm{n}=7$, $\mathrm{Ro}=0,706$, mas com espalhamento de cerca de uma dezena de outros pontos analiticos acima do ali nhamento principal. W.TEIXEIRA (1981) obteve para os mesmos me tassedimentos ưna isöcrona de $\mathrm{T}=660 \mathrm{~m} . \mathrm{a} ., \mathrm{n}=7$, Ro=0,708, com três outros pontos dispostos em isócrona paralela para uma razão ini cial de 0,720 , persistindo alguns pontos analiticos destacadamen te acima dos alinhamentos obtidos.

No Piancó-Alto Brigida, W.TEIXEIRA (op.cit.) obteve tam bëm uma isöcrona de referência de $\mathrm{T}=580 \mathrm{~m} . \mathrm{a} ., \mathrm{n}=10$ e $\mathrm{Ro}=0,707$, com apenas dois pontos analíticos acima, em alinhamento paralelo, pa ra razão mais alta.

No Riacho do Pontal, M.HAMA (in SouzA et al., 1979) ob teve para os "ganisses Rajada" e "micaxistos de Afrânio" uma isó crona de referência de excelente qualidade analitica, onde $\mathrm{T}=563 \pm$ $40 \mathrm{~m} . \mathrm{a} ., \mathrm{n}=5$ e $\mathrm{Ro}=0,712$.

Estas isócronas, como jả dito, expressam fenômenos físicos significativos dentro do intervalo do Brasiliano, mas cuja interpretação geológica deixa espaço a algumas indagações não descartäveis no presente curso dos conhecimentos. 
A interpretação mais singela seria a de aceitar a ülti ma fase de deformação e metamorfismo desses sistemas como respon sävel pela impressão dessas idades (560-660 m.a.), e descartar tó da a história vulcano-sedimentar e diastrófica anteriores. Mas este seria um procedimento precipitado (MOORBARTH, 1975a) e inad vertido, porque essas idades obtidas poderiam remontar às fases tectogênicas anteriores. Sem a utilização de novas técnicas de anälise, dentro do método $\mathrm{Rb} / \mathrm{Sr}$ (isócronas minerais) ou sem a in trodução de outros métodos de maior poder de resolução, pouco se pode adiantar de conclusivo.

Por outro lado a re-homogeneização completa dos siste mas isotōpicos, mesmo em metamorfismo de fácies anfibolito, só ocorre em proporções limitadas, como regra (MOORBARTH, 1975b; MC REATH, 1977). Verdadeiro retrabalhamento de material crustal siảlico só ocorre em escala moderada, em quaisquer das circunstân cias geodinâmicas mais conhecidas. De fato, há ainda um fosso considerâvel entre os dados geocronológicos obtidos e o conheci mento da evolução petrológica e estrutural desses sistemas de do bramentos, intransponível diante da incompetência da atual escala de trabalhos geocronológicos efetuados (reconhecimento).

As amostras cujos pontos analiticos se distribuem acima das isócronas de referências têm evidentemente diversas possibili dades de explicação: causas de fonte, causa de idades residuais mais antigas preservadas, idades mistas, etc. A elucidação não é possível no estāgio atual da anälise, e todo parecer conclusivo que se queira formular é precipitado. Na coluna de relações es tratigráficas do mapa, a posição de Proterozóico não diferenciado corresponde ao insofismável laudo dos dados geocronológicos até o presente. 


\section{7 - DOMINIO JAGUARIBEANO (III)}

Esta porção centro-ocidental do Nordeste se caracteriza pelo predomínio territorial da exposição de terrenos gnaíssico-migmatíticos (A) e migmatítico-graníticos $\left(M_{1}, \lambda_{2}\right)$, com preserva ção descontínua dos cinturões de metamorfitos, esgarçados pela ação conjunta de agentes tectônicos e erosivos policíclicos.

Chama a atenção a notória concentração de geofraturas no interior (Tauá, Rio Groairas, Senador Pompeu, Orós, etc.) deste dominio e nas cercânias de suas zonas mais externas (Sobra1, Jagua ribe-Pau dos Ferros, Patos/Malta, Paulistana/Pernambuco), fatos geológicos da proposição ora formulada. Outrossim, há destaque deste domínio vestigial por característica, entre domínios distin tos( $I$ e IV)que preservam suas rochas supracrustais de forma imponente, o que ẻ atribuível em comportamento geológico singular (e geodinâ mico). A vocação ascencional, perdurante pelo menos no Fanerozói co, e a privilegiada ação dos ciclos erosivos não pode ser fortuí ta.

Por outro 1ado, soma-se a observação que os remanescen tes metassedimentares prê-cambrianos ("Grupo Ceará")e os depósitos cambro-ordovicianos e mesozóicos, etc. têm controle, arranjo e for ma em dependência destas falhas profundas.

No tocante à formulação de unidades geotectônicas e $1 \underline{i}$ to-estratigräficas, permanecem válidas as assertivas de dificuldá de preconizada por R. CRANDALL, sete dẻcadas atrás. As nomeações e subdivisões propostas posteriormente para o seu "Complexo Funda mental" (Complexo Caicó, Complexo Tamboril-Santa Quitéria, Comple xo Nordestino, Grupo Itataia, etc., etc.) são todas elas tentativas ou operacionais, atendendo a apelos geográfico-geológicos 1o cais, e que não resistem a uma apreciação de cunho lito-estratigrá fico criteriosa, no nível presente do conhecimento. Da mesma for ma, a Série Ceará (Grupo Ceará, Pєce) é termo que permanece para as bandas xistosas, por razões históricas. A ordem de sucessão das unidades litológicas, a separação do embasamento (Pعce ${ }_{1}$, A?) de algumas destas bandas, as diferenças radicais de uma ocorrên cia a outra, etc. são problemas em geral que não podem ser oblite rados pelo jugo de uma designação. 
Para facultar razões descritivas, foram identificados neste domínio (Fig. 1) quatro grandes äreas de exposição dos terre nos de alto grau - os "maciços" -, e dois sistemas de bandas metas sedimentares, que circundam ou se ramificam entre estes maciços.

A natureza 1ito-estrutural das zonas dos maciços e do embasamento sotoposto às faixas metassedimentares è a mesma, e a condição de limites geológicos inferenciais (maciços/faixas) vigora na presente instância do conhecimento. Não hả dados para defí nir os limites atuais (expositivos) ou pretēritos (geotectônicos) entre estas diferentes entidades lito-estruturais.

\section{1 - EMBASAMENTO}

\section{1 .1 - Os Maciços}

As caracteristicas geolögicas gerais dos maciços foram discutidas preliminarmente (item 3.4.2.) na introdução à geologia regional, e serão evocados na discussão seguinte.

a) Os Maciços de Santa Quitéria e Maranguape são forma dos predominantemente por rochas migmatíticas, com estruturas meta texiticas e facoidais nas suas margens, e estruturas diatexíti cas (homófonas frequentes) no seu interior. Diversos corpos gra níticos $\left(\lambda_{2}\right)$ podem ser identificados nas imediações de Santa Quité ria, em contatos transicionais com suas encaixantes. Como resí duos dos processos polifásicos de migmatização ocorrem anfibolitos, cálcio-silicäticas, formações ferríferas, em värios locais.

$\mathrm{Na}$ parte noroeste do Maciço de Santa Quitéria ocorrem gnaisses a anfibólio e biotita, biotita xistos granadíferos com muitas intercalações de quartzitos (qz) e rochas cảlcio-silicá ticas. Nas rochas gnảissicas é comum a presença de sillimanita, cianita e piroxênios, denotando grau elevado de metamorfismo regio nal. O "trend" estrutural da foliação è NNE-SSW.

Nas imediações leste de Santa Quitẻria, MENDONÇA et al., 1982 identificaram cinco fases de deformação nas rochas deste emba mento ("Complexo Tamboril/Santa Quitëria"), que se estende à zona do alto Rio Curú, sotoposto às rochas do chamado "Grupo Itataia" (caracterizado por mineralizações uraniferas). As margens leste e. 
sul do maciço apresentam estruturas de acavalamento sobre as ro chas adjacentes.

Värias rochas graniticas intrusivas cortam as rochas me so e catazonais de Santa Quitéria. Destacamos o "plug" granodio rítico porfirítico da Serra da Barriga, totalmente secante às es truturas dos gnaisses e quartzitos do embasamento (a leste de So bra1), e os "stocks" de granitos alaskiticos estaníferos de São Paulo e Morrinho (noroeste de Santa Quitéria). Na margem orien tal do maciço hã värias menções à granitos e sienitos uraníferos. Todo o maciço com maior ou menor frequência é cortado por diques graniticos, riolíticos, etc. que tomam maior vulto a norte e a sul de Independência.

b) No Maciço de Tróia destacam-se primeiramente os ter renos migmatíticos com forte herança máfico-ultramảfica. Próximo a Tauả, aflora extensa massa diorítica (d), contendo núcleos de olivina-gabro (gb), com variado grau de transformação migmatít ca. Mais ao norte, em Tróia, e em Madalena (sul de Canindé) ré petem-se núcleos migmatíticos desta natureza, ao lado de gnaisses anfibolíticos, anfibolitos com intercalações máfico-ultramáficas, etc. e um característico padrão não linear das estruturas, domos e ovais tîpicos de uma deformação policíclica. Na periferia dos núcleos granitizados aparecem serpentinitos cromitíferos, xistos antofiliticos e tremolíticos.

O Complexo Independência ( $\left.P_{\varepsilon} i\right) \vec{e}$ caracterizado pela in terlaminações de gnaisses e anfibolitos. Os gnaisses são de vá rios tipos, incluindo-se tipos ricos em plagioclảsio (anortosí ticos), hornblenda-gnaisses, leptinitos, etc. Os anfibolitos são orto e parametamórficos. Alguns gnaisses preservam nítidas estru turas/relações de contato de rochas igneas primitivamente. As in tercalações de xistos a anfibólio, clorita e tremolita, quartzi to com magnetita, cảlcio-silicáticos, etc.são comuns.Vảrios corpos gabróides cortam esta ampla sequência vulcano-sedimentar e se mostram migmatizados juntos com ela em fases posteriores da evolução. A estruturaçäo é complexa, o predomínio de direções NNE-SSW não oblitera o resultado de vários processos deformacionais. 
"Stocks" granîticos intrusivos, porfiriticos e equigranu lares ocorrem na borda sul do Maciço de Tróia. Enxames de diques que incluem riolitos, andesitos, quartzodioritos pórfiros, aplitos, pegmatitos, veios de quartzo, etc., são comuns de Cococi para o norte, cortando os granitos intrusivos, as massas dioriticas de Tauá e o Complexo Independência, etc. Merecem destaque os diques anelares do norte de Tauá, constituídos por granitos róseos com hornblenda.

c) O Maciço de Rio Piranhas compreende outra ampla ärea com predominância de rochas migmatiticas e graniticas.

$\mathrm{Na}$ sua parte leste e no embasamento do Sistema Seridó foi identificado o "Complexo Caico", de idade arqueana, constituí do por um contexto meta-vulcânico-plutônico-sedimentar, que inclui paragnaisses arcoseanos quartzitos, ortoanfibolitos, gnaisses gra níticos, etc. com subordinados horizontes cälcio-silicảticos e car bonáticos. Predomina estrutura complexa, com padrōes de interfe rência do tipo domo e bacia alongados na direção NNE-SSW, e via de regra uma fase de deformação a mais que as supracrustais do Seridó (JARDIM DE SA e SALIM, 1980). A fäcies de metamorfismo é anfiboli to alto, com migmatização frequente. A separação deste complexo das supracrustais migmatizadas é problemática e discutivel por to da zona central e centro-oriental do maciço (salvo onde hà dados estruturais e geocronológicos decisivos). Assim como é problema aberto e extensão desta entidade arqueana (BRTTO NEVES et a1.,1975) para sul e oeste, dentro e fora do maciço do Rio Piranhas, extrapo lação de nomenclatura comum na geologia do Nordeste.

$\mathrm{Na}$ sua parte sul, ao longo do lineamento Patos, o maciço de Rio Piranhas mostra grande contingente de rochas bäsicas e in termediärias (dioritos, quartzodioritos, granodioritos) granulares, deformadas e com grau variävel de migmatização. Entre estas se incluem remanescentes ultramäficos (ocorrências de amianto) e metas sedimentos (gnaisses arcoseanos, quartzitos, formações ferriferas), desde Cedro (CE) até Patos (PB).

Grandes plutões de estruturação e histöria complexa apa recem na porção central do maciço, de Pombal para o norte. Na sua 
maioria são de rochas granodioriticas, porfiriticas e graniticas equigranulares. A presença de relíquias melanocrāticas é comum e característica destes batólitos, aparecendo dioritos e gabros associados, como enclaves ou como fases marginais.

Há grande variedade de tipos petrogräficos e de estrutu ras, e fases diatexiticas com franca herança metassedimentar, com enclaves de xistos e gnaisses, bem como de fäcies graniticas equi granulares sem enclaves. Ocorrem alguns corpos mistos, em parte om herança metassedimentar ("tipo $S^{\prime \prime}$ ) em parte com herança ígnea ("tipo I"). Nas zonas intrabatoliticas a dominância è de diatexí tos, tambëm com remanescentes mäficos e/ou metassedimentares, e via de regra, os contatos externos dos batölitos são inferenciais.

$\mathrm{Na}$ porção ocidental do maciço (e no embasamento do siste ma Jaguaribeano) reaparecem gnaisses granodioriticos a tonaliticos bandados, e gnaisses graniticos a granodioriticos (orto-rochas ar queanas ?), cortados por corpos graniticos, porfiroblásticos a hornblenda, muito alongados (sintectônicos brasilianos?). Alguns remanescentes supracrustais começam a ocorrer do meridiano de Pau dos Ferros para oeste (quartzitos, cảlcio-silicáticos, xistos), pro visoriamente correlacionảveis com aqueles do Grupo Cearā, consubs tanciando uma zona transicional de passagem entre o "Maciço" e o sistema Jaguaribeano, mais a oeste.

\section{1 .2 - Exposições Interfaixas}

As demais äreas de exposição do embasamento entre as fai xas xistosas sãomeras extensões de terrenos descritos nos maciços.

$\mathrm{Na}$ ârea de Crateús, BARBOSA et al., 1977, descreveram vā rios tipos de gnaisses, a biotita, a biotita-hornblenda, a horn blenda-diopsïdio, a sillimanita, etc. ao lado de metatexitos de estrutura variada. Importantes são as intercalações de cálcio-silicáticas e märmores, nesta ärea (e em vārias outras) e corpos ga bróides - de pequena dimensão - intercalados neste embasamento.

$\mathrm{Na}$ ärea de alto curso do Rio Curü (região de Itataia), MENDONÇA et a1., 1982 destacaram no contexto do embasamento o Gru po Itataia, discordante sobre o "Complexo Tamboril Santa Quitëria" (embasamento do Maciço Santa Quitêria). Este grupo consiste de uma 
sequência metassedimentar, composta de gnaisses (granada gnaisses, leptinitos) e migmatitos basais ("Formação Serra do Céu") quartzí tos micāceos e com hematita ("Formação Laranjeiras"), biotitar -gnaisses e sillimanita gnaisses a granada ("Formação Barrigas") e uma unidade de calcários e cälcio-silicatadas ("Formação Alcantill"), no topo. Esta sequência, de grande importância quanto as minerali zações fósforo-uraníferas da área, ē marcado pela superposição de no mínimo três fases de deformação, encerrando um padrão de zonas dômicas de foliação, observāveis no mapa geolögico. MENDonçA et a1., (op.cit.) sugerem posição lito-estratigräfica acima do "Com plexo Tamboril Santa Quitëria" e idade do Proterozóico Inferior(Ci clo Transamazônico) para esta sequência.

$\mathrm{Na}$ parte mais oriental do domínio predominam värios tí pos de gnaisses, inclusive piroxênio-horblenda gnaisses, além de xistos e gnaisses grafitosos (em Solonópole, por exemplo). Local mente são conhecidas ocorrências cálcio-silicatadas, algumas com pequena concentração de "skarns" scheelitíferos. Pröximo a Canin dé, voltam a ocorrer lentes destacáveis de mármores e vestígios de meta-u1tramäficas (talco-xistos), dentro de um contexto regional dominante de gnaisses e migmatitos.

Ao longo dessas exposições do embasamento registra-se a ocorrência de vârios batölitos e "stocks" graniticos alongados, em parte associados à falhamentos. São rochas graniticas e grano dioríticas, porfiriticas, monzonitos porfiriticos (Quixadā) atribuídas ao Ciclo Brasiliano, mas muito pouco conhecidas de fato. Em Solonópole, Itapiuna e Cristais ocorrem distritos pegmatitíferos importantes, mineralizados em berilo, tantalita-columbita, cassite rita e espodumênio. Os pegmatitos de Itapiuna (oeste de Cristais) e Cristais são principalmente litiniferos.

\section{2 - OS SISTEMAS DE DOBRAMENTOS VESTIGIAIS}

- As faixas Xistosas -

\subsection{1 - Aspectos Geolögicos Gerais}

0 tipo de relação estrutural-estratigräfico entre o emba 
samento e as faixas xistosas é muito variado, do ângulo atual da observação. Em muitos locais os terrenos gnáissicos e migmatíti cos constituem claramente o embasamento destas faixas. Mas, em algumas äreas, a diferença entre os dois tipos de terrenos $\vec{e}$ ape nas gradual, e a cartografia geológica tem seguido, em geral, o ressalte topográfico como se fora contato. Vārios tipos de rela cionamento são encontrados, calhas sinclinoriais, embainhamento rutura1, etc.

Estas faixas xistosas são muito irregulares quanto a for ma, apresentam dobramento de xistosidade apertado, mergulho do plano axial forte em geral, ou inclinado,e parecem corresponder a restos de entidades geológicas mais extensas. A designação de Grupo Ceará é genérica e provisória (H. SMALL,1914), pois só nos ültimos anos vem se firmando a conscientização dos muitos grupos litológicos envolvidos.

Recentemente, JARDIM DE SA e FOWLER, 1981 identificaram inclusive restos de sequências do tipo "Grupo Ubajara" entre es tas supracrustais, no substrato dos grabens de Cococi e São Ju lião, embutidas por zonas de falhas.

No sul de Cococi, na ärea de Pio IX, ocorre uma sequên cia de gnaisses com intercalações de quartzitos, märmores, leptí nitos e talcoxistos $\left(\mathrm{P}_{\varepsilon} \mathrm{Ce}_{1}\right)$, destacado no mapa,que mostra conta tos transicionais (ao menos em parte) com os xistos do Grupo Cea rä. São biotita-gnaisses e hornblenda gnaisses, que migmatizados são em geral mapeados no contexto do embasamento, mas que foram discriminados entre as supracrustais por OLIVEIRA et al., 1974.

De uma maneira geral dominam micaxistos e gnaisses gra nadiferos, com intercalações de quartzitos (basais ou não) e mär mores. Outras ocorrências com filitos, sericita clorita xistos, meta-vulcânicas básicas e ảcidas tem sido mencionadas. A expres são topogräfica positiva é suportada por quartzitos ou por rochas cataclästicas, nas zonas de contato falhados embasamento/supracrus tais.

O panorama geral de "schist belts" encravados esparsa mente no embasamento, a dificuldade de correlacionä-1as integra $\underline{1}$ mente, a presença de granitos intrusivos, os problemas de ordem 
geocronolögica a serem comentados, etc. têm plena analogia na con traparte africana (Nigëria), consoante os dados bibliográficos (MCCURRY, 1971; GRANT, 1978).

\section{2 .2 - Principais Litotipos}

$\mathrm{Na}$ ärea de Novo Oriente destaca-se maciços de serpenti nitos e talcoxistos (ocorrências de amianto, níquel e ferro) con tidos na unidade inferior. A unidade superior é composta por xis tos e filitos, com intercalações de märmores, câlcio-silicatadas, anfibolitos, metabasitos e possivelmente "cherts" (BARBOSA et al., 1977 ).

Nas ocorrências ao norte e noroeste de Independência, hả värias intercalações de quartzitos. Os xistos contém sillimanita, cianita, alëm de rutilo em venulações quartzosas. 0 dobramento da xistosidade é isoclinal, com plano axial inclinado para noroes te (vergência para sudeste).

Nas faixas ao sul de Tauá aparecem espessos horizontes quartzitos basais descontínuos, seguidos de biotita xistos gnaisses a granada, com intercalações de quartzitos e de mármores bastante portentosos. Filitos, sericita clorita xistos ocorrem ao sul de Cococi, tambëm com intercalações de quartzitos e märmores.

$\mathrm{Na}$ faixa de Orós é possível distinguir três dominâncias litológicas. Ao norte, predominam quartzitos e filitos. 0 tre cho sul é caracterizado por märmores magnesianos, dolomitos e mag nesita $(300$ a $400 \mathrm{~m})$ no topo de uma espessa sequência de quartzí tos, gnaisses e biotita xistos. Diques e sills de anfibolitos são mencionados por BODENLOS (1950) que descreveu os depósitos de magnesita da ärea ao sul de Iguatủ e Icó. Estruturas estromatolí ticas foram descritas por RIES (1977) em algumas pedreiras locais.

Faixas de xistos incluindo máfico-ultramäficas foram descritas em Lavras da Mangabeira (sul do Cedro, CE) como perten centes ao Grupo Cearä (SANTOS et a1., 1981), incluindo rochas anfibolitizadas, talco xistos e serpentinitos, alēm de formações ferriferas e meta-cherts. Micaxistos com intercalações quartzi ticas e calcárias e filitos grafitosos sobrepõem-se à sequência mäfico-ultramáfico basal, incluída em gnaisses. 
Nas faixas mais ao norte (sul de Itapagê) voltam a pre dominar micaxistos e gnaisses granadíferos, com intercalações quart zíticas e calcárias subordinadas.

Ao sul do graben de Cococi (localidade da Fazenda Nova), adjacente a linha de falha de Senador Pompeu e entre esta e a fa Iha do limite sul do graben, JARDIM DE SĂ e FOWLER, 1981 descreve ram supracrustais de baixo grau, semelhantes as do Grupo Ubajara. Uma unidade basal de ardósias, metagrauvacas e metarcöseos e uma unidade superior de metarcóseos e metabrechas polimícticas, com acamadamento dobrado NNE-SSW, de forma apertada, desenvolvendo cli vagem ardosiana.

Ao sul de Pio IX (paralelo $7^{\circ}$ OOS) e de São Julião, nova mente assoalho de grabens preenchido por sedimentos moläsicos (e com representação inviável na escala 1/1.000.000) estes autores se referem a filitos verdes finos, metagrauvacas e mármores dobra dos isoclinalmente (com uma fase de redobramento sobreposto), ocu pando diminutas āreas de exposição. Estas ocorrências, importantís simas para o conhecimento geolögico regional, ocupando calhas ta frogênicas ensiālicas (dobradas e intrudidas por graníticas) de vem ser destacadas do Grupo Ceara desde ja e melhor estudadas. De vem corresponder a um registro lito-estratigräfico concreto do Ciclo Brasiliano, como depósitos sinorogênicos ou como molassas precoces (observação: não cartografáveis na escala do mapa, estan do recobertas pelo símbolo da unidade $\mathrm{Rj}_{1}$ ).

$\mathrm{Na}$ fossa de São Julião (COMDEPI, 1982, inédito) os me tassedimentos epizonais estão atravessados por aparelhos vulcân cos ("Complexo magmätico Pocinhos") tipo "pipe" formados por ande sitos e brechas andesiticas, e cortados por um cortejo de peque nas intrusões félsicas, incluindo tonalitos, granodioritos, gran tos e quartzo-pórfiros. Os metassedimentos tem sido equiparados aos do Grupo Jaibaras, e o magmatismo aos eventos Parapui-Meruoca daquela faixa marginal.

\section{3 - DEPOSITOS MOLASSOIDES}

a) $\mathrm{Na}$ "Bacia de Cococi" ou do Rio Jucä destaca-se uma unidade inferior psefitica a psamitica, composta por brechas 
conglomerados polimíctitos, com intercalações de arenitos, silti tos e argilitos para o topo e para o centro do graben, e atingin do espessuras de atē $800 \mathrm{~m} .\left(\mathrm{Rj}_{1}\right)$. Segue-se uma unidade muito es pessa de argilitos, folhelhos, folhelhos calciferos, siltitos cấ1 cio-ferruginosos $\left(\mathrm{Rj}_{2}\right)$. Estas unidades sāo consideradas como equi valentes das Eormações Massapê e Pacujä (Grupo Jaibaras), por cor relação à distância. Uma unidade superior $\left(\mathrm{Rj}_{3}\right)$ é constituída por conglomerados polimícticos, em matriz grosseira ou pelítico-carbonatica que ocorre em värios compartimentos ao sul de cococi e de Pio IX, nem sempre de forma cartografävel na escala 1/1.000.000.

b) Entre estes compartimentos tafrogênicos do sul de Pio IX (ligadas com a projeção dos Iineamentos de Senador Pompeu e Patos), destaca-se o graben de "São Julião-Mandacarü", jā comentado. Sobre as supracrustais mencionadas anteriormente ocorrem brechas e conglomerados, com matriz arcoseana ou tufảcea, incluindo blo cos das rochas igneas intrusivas, fëlsicas e andesitos, e mesmo de rochas epizonais precedentes. A 1ito-estratigrafia desta ārea es tä ainda em processo de equacionamento, e a nomenclatura utilizada (Complexo Magmático, Unidade Catolê, Unidade Pös-Vulcânica) no pre sente $\bar{e}$ ainda de caráter experimental.

c) No baixo curso do Rio Barnabuiū, jā uma ocorrência de uma depressão tectônica, limitada por falhas, e preenchida por bre chas e conglomerados polimicticos, gradando para arenitos gros seiros (com níveis conglomeräticos e pelíticos), chamada de Bacia de Sitia $(\varepsilon O s)$. A vinculação ao Cambro-Ordoviciano é ainda puramen te conjectural - dedução e comparação - e assim como seu signi ficado tectônico demanda melhores razões. 


\section{8 - DOMINIO CENTRO-ORIENTAL (IV)}

A porção centro-oriental, entre outras semelhanças geoló gicas gerais com sua simétrica Jaguaribeana, se caracteriza pelo predomínio da exposição de terrenos de alto grau e preservação mo desta e retalhada de metamorfitos supracrustais, o que se credita a condições tectônicas especiais. São tantas as afinidades entre os dominios vestigiais (III, IV) quanto a natureza dos principais problemas, geológicos e terminológicos.

o limite deste dominio com o dominio central é proposto ao longo de uma série de linhas arqueadas do embasamento ajacente à zona de falha de Picui (ao norte) e seguinte a dorsal granítico-migmatítico de Teixeira (parte sul). A delimitação com o domínio sergipano é mais difícil de referenciar, como jā discutido. Pois a partir do eixo do maciço Pernambuco-Alagoas (paralelo $9^{\circ} \mathrm{Oos}$ ) co meçam a aparecer os reflexos magmáticos e tectônicos do envolvimen to da borda deste maciço na evolução da faixa Sul Alagoana. Para a Província Costeira, as Iinhas estruturais do dominio centro-orien tal chegam sempre diagonalmente à linha de costa, e como serā dis cutido, com imposições geolögicas fundamentais.

No interior deste dominio verifica-se grande concentra ção de geofraturas, ligadas direta ou indiretamente aos lineamen tos de Patos e Pernambuco, em geral formas fasciculadas dos mesmos. Rarefeitas coberturas fanerozöicas são encontradas neste dominio, circunstanciadas pela trama dessas falhas profundas. Na zona cos teira, tais falhamentos presidem subdivisões paleogeológicas de vulto, a serem comentadas.

Considerando as características geológicas do conjunto,é possivel dissertar três partes neste domínio, ainda que sejam am plos os tipos de interação entre elas: o Maciço Caldas Brandão São José Campestre (N), o Sistema de Dobramentos Pajeü-Paraỉba e o Maciço Pernambuco-Alagoas (S).

Neste dominio, a documentação cartogräfica e geológica $\vec{e}$ essencialmente de reconhecimento, havendo muita repetição de ma peamentos, em mesma escala, sem contribuições adicionais aos pro blemas. Mapeamentos de detalhe e semidetalhe (Curso de Geologia 
do Recife e SUDENE, principalmente) ocupam äreas isoladas, de mo destas dimensões.

\section{1 - EMBASAMENTO}

\section{$8.1 .1-\underline{\text { Os Maciços }}$}

a) O Maciço de Caldas Brandão caracteriza-se por possuir uma trama estrutural complexa, disposição transversal aos "trends" NNE-EW da província, e por concentração especial de dados geocro nolögicos do Proterozóico Inferior e Pré-Proterozöico. Sua estrü turação interna (e outras características geolögicas) lembra as dos "gneiss fold ovals" de SALOP, 1972, em escala reduzida, apesar da sobreposição conhecida de eventos dos Ciclos Transamazônico (migmatização, homogeneização isotópica regional) e Brasiliano (granitos intrusivos, filoneanas graníticas, tectonitos, resfria mento).

Extensas faixas gnáissicas e metatexíticas, com interca lações de leptínitos, anfibolitos e calcários (restritamente) de $\underline{s}$ crevem percursos flexuosos, que em parte circunscrevem alguns grandes nücleos ovöides, semicirculares e poligonais, compostos principalmente de diatexitos, com granitóides sincinemäticos (sen tido de MARMO, 1971) associados. Estes nücleos, como os de Natal, Presidente Juscelino, Cacimba de Dentro, Campina Grande, Marí- Caldas Brandão, etc. se destacam (em parte por expressão topogrä fica mais acentuada) dos gnaisses e metatexitos que os envolvem pelo contingente de rochas diatexiticas e graniticas com relíctos metabasiticos, e mesmo massas irregulares de dioritos e gabros na sua periferia, ou mesmo no seu interior (como em Campina Gran de, em Sapé, etc.).

Por toda borda sul do maciço, do interior para a costa aparecem värios corpos mäficos e ultramáficos, gabros, dioritos, piroxenitos, complexos gabro-anortositicos, granada-granulitos a dois piroxênios, etc. com grau variâvel de retrabalhamento pela migmatização, e que respondem por importante linha de anomalias gravimétricas positivas (mais ou menos ao longo do paralelo de Inga $\vec{a}-\mathrm{PB}$ ). Esta borda $\overrightarrow{\mathrm{e}}$ acompanhada por traços de falhas inversas 
é empurrões, na direção E-W, que definem a vergência para o norte da parte norte do Sistema Pajeú-Paraíba.

Alojadas em depressões tectônicas, do consórcio de fa Ihas profundas e estruturas sinformais aparecembandas sedimenta res estruturadas de ENE-WSW para NNE-SSW, compostas por biotita xistos granadíferos, biotita-muscovita-quartzo xistos e filitos,com intercalações metabasíticas locais. A designação de "Complexo Su rubim/Caroalina" abrange este contexto de forma provisôria. Uma ligação destes metassedimentos com aqueles do Sistema Piancö-Alto Brígida $j \vec{a}$ foi proposta por EBERT, 1970, e o problema não esta so lucionado.

Värios corpos de rochas graníticas e granodioriticas,ora porfiriticas, ora equigranulares, "stocks" e batölitos, se inserem e se ajustam às sinuosidades dos traços de foliação dos complexos gnäissico-metatexíticos, e no interior dos nücleos diatexíticos. Alguns desses corpos cortam nitidamente os graben-sinformais do complexo metassedimentar, e todos indistintamente estão referidos ao Ciclo Brasiliano. Outras manifestações ígneas, granitos róseos filonares, aplitos, pegmatitos, etc. que cortam inclusive rochas graniticas sin e tarditectônicas têm acusado idade compatînel com - àmbito do Ciclo Brasiliano.

b) 0 Maciço Pernambuco-Alagoas ocupa uma ärea triangular de cerca de $70000 \mathrm{~km}^{2}$, com base voltada para zona costeira, e com eixo dirigido de WNW-ESE para WSW-ENE, ao Iongo de cerca de $520 \mathrm{~km}$, constituindo a maior extensão continua de terrenos de alto grau do Nordeste Oriental, fora da Bahia.

Recentemente, uma sintese do seu conhecimento geolögico, de sua caracterização geotectônica e geofísica (BRITO NEVES et a1., 1982) foi efetuada, o que torna mais simples a abordagem deste tema. Do ponto de vista tectônico constitui um típico maciço me diano de primeiro tipo, que serviu de antepais dos sistemas de do bramentos adjacentes, que para ele dirigem centripetamente a ve $\underline{r}$ gência. Pela gravimetria ficou caracterizado um padrão peculiar com anomalias positivas circunscrevendo todo seu perímetro.

Resumidamente, o embasamento é constituído de terrenos gnaíssico-migmatíticos orto e para derivados (A) e por grandes ma ciços migmatitico-graniticos (granodioríticos) (M). Intrusivas 
cálcio-alcalinas, em "stocks" e pequenos batölitos, associados ao plutonismo dos sistemas confinantes ocorrem esparsamente. Restos de cobertura metassedimentar (quartzitos, micaxistos) podem ser observados na parte central (Garanhuns) e partes marginais do maci ço, alí embutidos por ações tectônicas ou como remanescentes de processos de granitização.

Os migmatitos constituem as rochas mais antigas do maci ço, sendo de grande diversidade composicional e estrutural. Entre aqueles de derivação metassedimentar podem ser vistos (em Cabrobó, por exemplo) restos e testemunhos de uma sequência muito variada, de quartzo-xistos, biotita-muscovita xistos, metarcóseos, quartzi tos, cảlcio-silicāticas, paranfibolitos e calcários, intrudidos por massas graniticas lamelares e irregulares. Os migmatitos der vados de rochas igneas intermediārias, mäficas e ultramäficas são reconhecidos e têm sido estudados em värias localidades (Cabrobó, Fazenda Nova, Limoeiro, Arco Verde, Bom Conselho, etc.), sendo grande a ênfase dada aos remanescentes de dioritos, gabros, gabro-anortositos (com Fe-Ti-V), piroxenitos e hornblenditos, em geral em grau precärio de preservação. Estruturas metatexíticas predomi nam e são värias as culminações locais de nücleos diatexíticos. Al guns septos de rochas granuliticas (a hiperstênio, a cordierita) têm sido identificados entre estes terrenos migmatíticos.

Os maiores complexos batolíticos do Nordeste ocorrem nes te maciço, resultantes de sucessivos ciclos de geração(e tipos) de granitos, com culminação provảvel no Ciclo Brasiliano. São maci ços extremamente heterogêneos em feições estruturais (migmatíticas, porfiröides, equigranulares, gnäissicas localmente) e composicio nais (granodioriticas predominantes) em qualquer escala de anäli se. Remanescentes paleossomáticos de natureza as mais diversas é traços dispersos de foliação - estruturas schlieren - contam a fa vor de uma evolução a partir dos terrenos migmatíticos (A), com os quais mostram passagens gradacionais, e a demarcação de contatos sempre discutível.

Uma série de corpos graniticos, quartzo-sienitos e sie nitos corta os terrenos de alto grau deste maciço, principalmemte na sua borda sul, ligados à evolução da Faixa de Dobramentos Sul Alagoana (como jâa discutido). Intrusivas fissurais de värios tî 
pos, veios pegmatiticos, apliticos e de quartzo constituem mani festações magmäticas tardias observäveis cortando todas as 1itolo gias acima mencionadas.

A Unidade Garanhuns, constituída de metaclästicos, quart zitos, quartzoxistos, metacōrseos e metagrauvacas, recobre em discordância estrutural os migmatitos do seu embasamento. Sua correlação com o "Complexo Surubim/Caroalina" ë inferencial, seu significado no quadro tectônico regional precisa ainda ser pers crutado.

A estrutura interna dos terrenos gnäissicos e migmatí ticos é notoriamente policiclica, cinco a seis fases de deforma ção tem sido reconhecidas unilateralmente, compondo formas extremamente intricadas de seus traços de foliação. Aliảs, raramente estes tra ços de foliação se orientam em paralelo ao eixo do maciço, haven do predomínio de disposições oblíquas. Isto significa que a frá ção crustal exposta entre os limites (pelo menos gravimétricos)dó maciço é fragmento de uma entidade tectônica maior, muito prova velmente com atual configuração adquirida nos processos tectôni $\cos$ (e magmäticos) do Ciclo Brasiliano.

A propósito a entidade geotectônica "maciço mediano" (BRITO NEVES, 1975) inclui como característica ser zona axial de convergência ("intermediate foreland", AUBOUIN, 1975) das faixas metassedimentares adjacentes. Mas, as fases de dobramentos da $x$ istosidade que permitiram esta conclusão raramente pode ser cons tatada na proximidade das bordas dos maciços, a não ser em carā ter residual, local. Toda margem norte e grande parte da margem sul e sudoeste do maciço sofreram processos de granitização (acre ção crustal) e aloctonismo no sentido das faixas marginais.Falhas inversas, empurrões, napismo, janelas estruturais, etc. são obser vações usuais nestas bordas.

Os tectönitos presentes no maciço Pernambuco-Alagoas constituem parcela importante de formação tardia de rochas do Ci c1o Brasiliano. Ao longo do lineamento Pernambuco e falhas asso ciadas hă sempre uma zona considerävel em espessura ( 1 a $5 \mathrm{~km}$ ) con tendo desde texturas facoidais a ultramilonitos. Nas margens do maciço são comuns estruturas laminadas inclusive de rochas graní ticas ("flaser"), mas milonitos são pouco comuns. 


\section{1 .2 - Terrenos Gnáissico-Migmatíticos do Sistema}

A condição de transição é observada entre o embasamento das faixas metassedimentares e os maciços, no tocante aos 1 itoti pos encontrados. Destaque inicial se faz ao estilo estrutural im posto ao embasamento do sistema (provavelmente no Ciclo Brasilia no), obedecendo a um traçado linear de NE (sul de Custódia) para EW (zona costeira) e a forma de uma grande oval afunilada e encur vada para o lado do mar.

No interior do sistema ganham realce alguns nücleos anti formais longilíneos importantes (Floresta, norte de Ibimirim, Cus tódia-Sumē, Umbuzeiro, Rio Monteiro - Aroeiras) onde afloram migma titos (metatexitos sobretudo) com predomínio de paleossomas mä $\underline{\underline{i}}$ co-ultramäficos. São comuns relictos de composição diorítica, gạa brica, anfibolitos e mesmo gabro-anortosíticos, ao lado de remanes centes metassedimentares (märmore, cälcio-silicäticas, leptinitos), em plano secundário. Adicionalmente värios corpos graniticos por

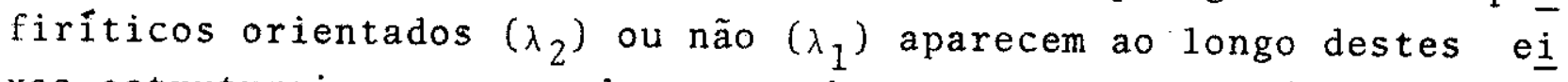
xos estruturais que comandam o arcabouço do sistema. E comum a atribuição de idade arqueana (vârios autores) ao contexto de migma titos presentes nesta zona, o que é viävel, mas falta respaldo geó cronológico. Ao longo do eixo Rio Monteiro - Timbaúba estas expo sições de migmatitos complexos são muito comuns, ao mesmo tempo que este eixo abriga uma zona de vergências centrífugas do ūltimo dobramento regional da foliação ("embasamento" e cobertura metasse dimentar), as quais demandam os maciços adjacentes ao sistema.

Contornando estes nücleos antiformais predomina uma se quência variada de gnaisses com muitos níveis de cālcio-silicảticas, märmores, quartzitos e rochas anfibolíticas, parte transfor mada em metatexitos. São gnaisses a biotita, gnaisses a muscovita, gnaisses a biotita e muscovita ("tipo São Caetano", SANTos, 1971), gnaisses a biotita e granada, com intercalações de cảlcio-silicáti cas (diopsîdio-gnaisses, escarnitos), märmores, anfibolitos, gnais ses graníticos ("tipo Sertânia"). Estas rochas predominam em expo sìção nos altos cursos dos rios Moxotó e Paraíba, são metamorfisa das na fäcies anfibolito alto, e com frequência exibem estruturas metatexiticas, diferenciando bandas quartzo-feldspäticas e mäficas. 
Estruturas estromäticas são comuns nestas rochas e naquelas da "ca pa" metassedimentar Surubim-Caroalina, tornando o discernimento entre elas difícil.

Hâ algumas evidências em favor de que este cortejo de gnaisses seja o produto do metamorfismo de uma sequência terrígena basal à do complexo metassedimentar "Surubim-Caroalina". Mas hä varios problemas a serem superados de ordem litológica e estrutu ral, principalmente na distinção entre estes gnaisses/migmatitos daqueles das zonas antiformais, e mesmo daquelas bandas da capa me tassedimentar que sofreram processos de migmatização.

Muitos mapas geolögicos de integração regional têm supri mido importantes fatias do "Complexo Surubim-Caroalina", incorpo rando-as indevidamente sob a êgide de "gnaisses e migmatitos indi ferenciados". No presente mapa deixa-se de configurar uma faixa de biotita-granada gnaisses e metarcóseos biotiticos, com interca lações de märmores, provavelmente pertencente ao complexo metasse dimentar, e situada do sul de Taperoá para leste. Conhecida pelo autor, e destacada no mapa geológico da Paraíba 1/250.000 (CINEP/ /ATECEL, 1979), esta faixa não aparece discriminada em qualquer ou tro mapeamento de âreas vizinhas, nem mesmo em mapas subsequentes da mesma ärea.

\section{2 - AS FAIXAS METASSEDIMENTARES}

o complexo metassedimentar Surubim/Caroalina (MELLO e SI QUETRA, 1971; SANTOS, 1971) inclui uma sērie de faixas xistosas e gnâissicas, com predominância de meta-pelitos de médio grau de me tamorfismo, nas quais se intercalam descontinuas secções de quart zitos, cẩcio-silicâticas e märmores.

Predominam biotita xistos com almandina e sillimanita (localmente cianita), metagrauvacas xistosas, biotita-muscovita xis tos, com muitas variações de oeste (Caroalina) para leste(Surubim) no conteûdo litológico primärio e na fäcies de metamorfismo. Fili tos e clorita xistos são mencionados nas ärea de Santa Cruz do Ca pibaribe e a leste de Soledade. Nas exposições a leste de Pernam buco são conhecidas várias intercalações de gnaisses granadíferos e de biotita xistos'a cordierita. A presença de quartzitos basais não ê frequente, o que dificulta a separação do contexto gnáissico 
sotoposto, havendo locais onde as intercalações quartziticas ocor rem em todo o perfil. As intercalações de secções de märmore e cálcio-silicäticas muitas vezes ocorrem no topo aparente da unida de (Surubim, Sul de Itabaiana-PB), mas não necessariamente, e cons tituem importantes jazimentos em exploração. Metabasitos ocorrem restritamente.

Migmatização destes metassedimentos ocorre com frequên cia, sendo comuns metatexitos estromáticos com paleossoma a bioti ta e granada, e como jä comentado, o que tem passado desapercebido por alguns autores. Inclusive pequenos nücleos diatexíticos têm sido constatados, de consumação localizada.

Não existem estudos detalhando o metamorfismo regional, mas pela descrição dos litotipos nos itens precedentes é fäcil concluir pelo extensivo predominio de fäcies anfibolito alto, com eventos de migmatização frequêntes no complexo metassedimentar.

\section{2 .1 - Tectônica e Magmatismo}

Toda a preservação do complexo metassedimentar conhecido obedece a injunções ruturais. A supra-estrutura crustal foi exten sivamente desgastada nesta parte da região.

O dobramento (de xistosidade) dos metassedimentos parece ajustado à série de antiformas longilineas dissertadas para o emba samento, podendo ser vistas exposiçōes de flancos (predominante) e nas terminações (sul de Monteiro, por exemplo). Mas sempre, hä fa thamento associado condicionando de forma variada estas exposições das supracrustais.

O dobramento ë holomörfico, longilïneo, dirigido de NE para EW, e é possível caracterizar vergência centrífuga. A parte norte do sistema (a partir do paralelo de Aroeiras-PB) mostra in clinação dos planos axiais, falhas inversas e mesmo empurrões (prō ximo a Itabaiana) vergentes para o Maciço Caldas Brandão. A parte sul do sistema mostra algumas evidências de vergência para o sul, mas muito empanadas e obliteradas pela fase que the $\vec{e}$ posterior e mais imponente (e de sentido conträrio) de aloctonismo da margem setentrional do Maciço Pernambuco-Alagoas. 
Persistente sistema de falhas direcionais NE, muitas de las emanadas da porção oriental do Lineamento Pernambuco recortam de forma marcante as rochas do complexo metassedimentar e do seu embasamento. Em parte porëm o rejeito direcional (à esquerda, em geral) a apenas a movimentaçãomais saliente, havendo sempre compo nente (ou fases de) movimento vertical, que coadjutor na preserva ção das supracrustais (como visto anteriormente).

No Sistema Pajeú Paraíba ocorrem alguns batólitos grani tícos (granodioriticos)importantes, alguns dos quais com nücleos ou relictos dioríticos e gäbricos preservados (sul de Taperoä, Tim bauba, São Josë Egito, etc.) e fäcies porfiriticas. Mas tambëm hä batolitos de leucogranitos e granodioritos, no interior (Sumë, Surubim, norte de Monteiro, Sitio dos Nunes, etc.) do sistema, bem como ao longo da dorsal tomada como seu limite norte (de Teixeira para Serra Ta1hada).

Ao longo da margem sul da dorsal de Teixeira ocorre um conjunto de plutōes e hipoabissais sieniticos, sempre associados à falhamentos, e que cortam rochas graniticas com as quais fazem con tatos. Estas rochas são acompanhadas por enxames de diques tardíos de natureza alcalina (sienitos, quartzo sienitos, etc.) e cálcio-alcalina (riolitos, dacitos) que extrapolam deste para o sistema contiguo ao norte.

Um notävel conjunto de rochas graniticas ("stocks" e filoneanas) ocorre associado ao lineamento Pernambuco, e principal mente ao longo da "falha do Congo", a partir do norte de Ibimirim. São rochas de natureza tardicinemática, descritos por SANTOS e VASCONCELLOS, 1973, como "tipo Moderna", incluindo hedenbergita adamelitos, granitos e granodioritos a ferro-hastingsita e em asso ciação com alguns filões pegmatíticos a amazonita.

\section{3 - SOMULA DOS DADOS GEOCRONOLOGICOS NOS DOMTNIOS VESTIGIAIS}

\section{3 .1 - Comportamento dos Maciços}

o comportamento geocronolögico dos maciços, como ficou 
explícito desde o início, é por caracteristica distintiva essen cialmente policiclico. Os dados disponiveis permitem analisa-los em conjunto.

Com referéncia a eventos de ciclos prë-Transamazônicos, estes sào exclusivos dos maciços. As melhores constatações do Evento Jequiẻ e anteriores foram obtidas no Maciço do Rio Piranhas (Complexo São Vicente/Caicó). As isócronas de referência para o Arqueano são de boa qualidade e a extensão territorial de tais ro chas è bastante ampla (BRITO NEVES et al., 1975; PESSOA, 1976).

Nos demais maciços os eventos do Arqueano estão sempre detectados de forma casual, em datações convencionais isoladas, ou ainda isócronas de referência precärias, sempre reiterando a neces sidade de refinamento no laudo geocronológico.

Os eventos Transamazônicos têm a melhor e mais extensiva representação no seio das rochas de todos os maciços. Isócronas $\mathrm{Rb} /$ /Sr verdadeiras (ém partes determinadas) ou de referência (grandes extensões) são obtidas comumente nos terrenos gnäissicos e migmatí ticos. Verifica-se inclusive identidade de comportamento geocrono lógico entre os terrenos gnäissicos e migmatiticos dos maciços e parte daqueles que compōem a infra-estrutura dos sistemas de dobra mentos, o que realça a extensividade dos processos do Ciclo Transa mazônico no Nordeste.

Em todos os maciços ê comum encontrar uma série de rochas gnäissicas e migmatiticas com idades convencionais em torno de 1000 - $1350 \mathrm{~m}$. a. Estas rochas, em diagrama isocrônico, dispõem seus pontos analiticos no espaço entre as isöcronas do Brasiliano e do Transamazônico. Em alguns maciços (Granja, Pernambuco-Alagoas, Rio Piranhas, etc.), a população e coerência destes pontos são per suasivas para o traçado de isócronas de referência exibindo idades dentro dos Eventos Espinhaço/Uruaçuano.

De ordinärio, estes dados são interpretados como de reju venescimento isotöpico parcial de rochas de ciclos mais antigos. Mas a quantidade crescente destes tipos de dados permite antever in terpretação menos cômoda e mais realista em futuro, quando for pos sível dirigir anâlise geocronológica mais aprofundada para estas ro chas, fora das cotas de reconhecimento. 
As Iitologias graniticas "lato sensu" dos maciços, de pe quenos corpos intrusivos a grandes batólitos (caráter polidiapíri co), sempre exibem idades no âmbito do Brasiliano, principalmente entre 540 - $660 \mathrm{~m} . \mathrm{a}$. As dissençōes deste comportamento, casos ra ros e discretos, imprescindem de re-exame. Outros litótipos de me nor expressão territorial (pegmatitos, augen-gnaisses, cataclasitos, milonitos), mediante o escasso quadro de dados disponíveis, também indicam idades dentro do âmbito do Brasiliano.

o caräter de policiclismo discriminado com os dados advin dos do método $\mathrm{Rb} / \mathrm{Sr}$ ê ratificado, com reservas, pelas idades aparen tes K/Ar. Pois o nümero de dados è muito pequeno ainda, e porque hả insofismável maioria de valores enfatizando os processos tecto no-termais brasilianos.

No tocante aos dados $\mathrm{K} / \mathrm{Ar}$ que indicam idade arqueana (ärea sul de Limoeiro, PE), eles são muito raros, e a qualidade das anāli ses é discutível, havendo necessidade de revisão das mesmas.

\section{3 .2 - Comportamento dos Sistemas}

O conhecimento geocronológico dos sistemas de dobramentos vestigiais $\vec{e}$ ainda muito pobre, no entanto algumas semelhanças no comportamento geral e nos problemas apresentados sugerem apreciação conjunta nesta oportunidade de sintese.

a) No Sistema Pajeü-Paraíba as amostras dos complexos gnäissicos e migmatiticos, de seus nücleos antiformais e das zonas adjacentes aos maciços confinantes, apresentam comumente pontos ana líticos nas isöcronas de referência de $1800 \mathrm{m.a}$., para razäo iní cial de 0,705 . Isto consigna assim a importância regional do Cicló Transamazônico, seja no retrabalhamento (mais provāve1) ou na forma ção destes complexos, segundo os dados coligidos por BRITO NEVES, $1980,1981,1982$.

Para os complexos gnäissicos/metatexíticos, tipos "São Caetano" ou "Sertania", como descritos, não se conhece um ünico da do geocronológico, o que ë prioritärio para pesquisas em futuro.

As rochas do Complexo Metassedimentar (Complexo Surubim/ /Caroalina), as rochas graniticas e os tectonitos mostram pontos 
analiticos segundo a isócrona de $660 \mathrm{~m} . \mathrm{a}$., para razões iniciais na ordem de 0,710 $\pm 0,002$. Algumas amostras desse complexo se colocam em posiçāo intermediāria entre as isócronas do Brasiliano e do Tran samazônico. Alguns desses pontos intermediärios são de amostras pe trograficamente inseparäveis daquelas que definem a isócrona bras $\underline{i}$ liana.

Assim, conquanto a presença de processos tectono-termais significativos do Brasiliano seja insofismävel neste sistema, a real natureza e extensão desses processos não podem ainda ser esclareci dos.

A maioria dos dados K/Ar se referem a valores de resfria mento entre $520-610 \mathrm{~m} . \mathrm{a}$., endossando a importância e extensivida de do evento do Ciclo Brasiliano. Alguns raros dados de rochas do embasamento apresentam idades aparentes acima desse intervalo, como incidencias locais de rejuvenescimento isotónico narcial do substra to gnáissico e migmatítico.

b) No Sistema Jaguaribeano as rochas dos complexos gaáiss cos e migmatíticos, apesar de muito esparsamente amostradas, apre sentam tambëm dados convencionais do Transamazônico, sendo colinea res em diagrama isocrônico de uma isócrona de referência de $200 \overline{0}$ m.a. com razão inicial de 0,705 (W. TEIXEIRA, 1981, BRITO NEVES, 1975).

As rochas das bandas metassedimentares (Orös, Barnabuiu, Independência) apresentam pontos analíticos na isócrona de referên cia de $050 \mathrm{~m}$. a. para razão inicial bastante elevada (Ro > 0,720), de interpretação problemätica. Todas essas rochas mostram injunções dos processos lineagênicos característicos do sistema em análise.

As rochas graniticas exibem idades convencionais brasilia nas, e se alinham sem problemas em isócronas referentes a este cí clo.

Hâ alguns pontos analíticos de rochas dos complexos do em basamento (gnaisses, migmatitos, anfibolitos) em posição intermediä ria às isócronas do Transamazônico e Brasiliano. Mais raramente in dicam valores de idade aparente K/Ar prë-brasiliana para esse con texto infra-estrutural. 
Desta forma, no seio dos cinturöes möveis vestigiais es tão bem impressos registros isotöpicos importantes de dois ciclos geodinâmicos (Transamazônico e Brasiliiano), bem como de uma série de eventos discretos de idade intermediāria a eles, e envolvendo rochas infra- (maioria) e supracrustais, mas a natureza e as carac terísticas dos processos geológicos responsáveis por este policí clismo não puderam ser esclarecidos ainda, e sua discussão congraça muita especulação e poucos resultados conclusivos.

As afirmações peremptörias no campo da geocronologia, no Nordeste, em geral, não são possíveis, sendo plenamente desaconse Iháveis. Sobre a idade de sedimentação (e vulcanismo associado)des tas supracrustais não hä dados, nem eles são exequíveis com os mëtó dos em uso no Nordeste ( $\mathrm{Rb} / \mathrm{Sr}, \mathrm{K} / \mathrm{Ar}$, principalmente), apesar de que muitas especulações tomem curso e não possam ser evitadas. 


\section{9 - LiNEAMENTOS E GEOFRATURAS}

Uma das feições mais características e de vulto no panora ma da geologia regional do Nordeste, em qualquer escala de anảlise, $\ddot{e}$ a presença de extensas zonas lineares de mobilidade crustal comu mente designadas de lineamentos, ou ainda simplesmente relatadas como falhas, atreladas a uma localidade típica.

As zonas de movimento kineagênico (HILLS, 1963) contam com uma prolífera bibliografia no Nordeste e fora dele, e não menos di versificado cotejo de designaçöes visando definir as estruturas mu niciadoras, a saber: "1ineamento", "1ineamento cardinal" "falha pro funda", deep fault , deep fracture zone, "geofratura", "geossutura", etc... No Nordeste, estes tipos de estruturas e os problemas de no menclatura e anālise a elas inerentes, assumem condições de paradig ma.

Constam geralmente de zonas de falhas paralelas, formando feixes estreitos ( 1 a $5 \mathrm{~km}$ ) que se estendem por dezenas e mesmo cen tenas de quilômetros, de rochas cataclästicas e miloníticas que po dem impor e condicionar feições fisiogräficas (relevo, hidrografia, etc.) ao longo de toda sua extensão ou partes dela. Säo estruturas vigorosas, capazes de delimitar e ordenar as unidades geotectônicas primärias da região, como visto, os maciços e os sistemas de dobra mentos, ou ainda, quando interiores a estas unidades sobrepor suas caracteristicas tectônicas de forma notável.

Aos caracteres de zona estreita e alongada, atuação poli cíclica, com variação no tipo e intensidade dos rejeitos no espaço geogräfico e no tempo geológico, somam-se vārias outras implicações diretas e ligadas à sedimentação, magmatismo, morfologia regional, etc.

o pröprio padrão em leque de distribuição das linhas es truturais do Nordeste, e por fim a proppria forma geral externa assü mida pela região sāo produtos de, injunções dos principais lineamen tos (Pernambuco, Patos, Senador Pompeu, Sobra1). A magnitude des tas estruturas pode exceder, nos casos mais extremos, a pröpria di mensão do continente, posto que $\vec{e}$ comum o reconhecimento da conti nuidade destas estruturas no territörio africano, o que tem sido feito por vários autores, em diferentes oportunidades. 
De inicio, compondo-se em paralelo com os lineamentos, pa ra depois formar ângulos agudos com eles, é comum se originarem vä rias outras falhas, com características de ativação policíclica; e, que exercem papel importante e delongado no interior dos maciços e faixas de dobramentos para onde são emitidas.

Via de regra, em mapas de diferentes escalas, esses linea mentos vêm representados por um ou dois simples traços de falha mais ou menos contínuos, ao que se acrescenta a simbologia de movi mento direcional. Esta representação simplista configura a um sö tempo a dificuldade de expressar o polimorfismo do rejeito em vārias fases, bem como traduz a fase (as fases) mais conspicua de movimen to observado em primeira mão, na anảlise superficial de cartas geó lógicas ou de imagens de värios tipos.

Todas estas são asserçōes de ordem muito geral e pequena profundidade, sendo cunhadas nas observações efetuadas em escala de reconhecimento e nas conclusões das raras anälises mais demoradas, localmente realizadas. De fato, não existem estudos sistemäticos compativeis com a ordem de importância destes lineamentos. Esta con clusão se refere tanto à anälise de seus movimentos (em diferentes tempos e espaços) quanto a sua significação concreta em escala de litosfera.

Os estudos geológicos têm tido caräter passageiro e são rarissimos os enfoques locais (por exemplo: COBRA, 1966; SANTOS, 1971: AGRAWAL, 1981).

A utilização de esquemas de interpretação simplistas, cal cados no modelo de falhas transcorrentes de MOODY e HILLS (1956), têm sido o passo mais avançado de anälise estrutural encontrado (MELLO et a 1., 1978; MELLO, 1979), e, certamente não satisfaz às condições de anisotropia e policiclismo da região afetada.

Os poucos ensaios de anälise estrutural preexistentes, co brindo os sistemas de dobramentos, têm deixado à margem estes elé mentos ou os têm mencionado de forma superficial ou secundäria. E forçoso reconhecer, que na instância atual do conhecimento não se pode sequer discriminar estas geofraturas (estruturas criadoras)das grandes falhas geradas (estruturas criadas) ao longo da sucessão de fases de deformação das supracrustais dos diferentes sistemas.

A falta de informações geofísicas, constitui um empecilho insuperävel para a interpretação destas estruturas na escala. da 
crosta e em relação às estruturas adjacentes. A implantação de pes quisas geofísicas em andamento é acontecimento promissor de onde muito se espera.

Como jâa mencionado, as linhas estruturais do Nordeste ex bem uma interessante distribuição, de forma que elas chegam diago nalmente à linha de costa. Na verdade este è um arranjo final, de caräter sobreposto, como pode ser deduzido de qualquer mapa geológ co regiona1, e para o qual foram decisivas a trama e a operosidade dessas falhas profundas. Estudos para reconstituir a forma que an tecedeu este arranjo atualmente observado são muito raros ainda.

O lineamento Pernambuco delimita grande parte do norte do Maciço Pernambuco-Alagoas. O lineamento Patos, em sua parte cen tral de exposição delimita o Maciço do Rio Piranhas do Sistema Pian có - Alto Brigida, e mais a leste, a forma de suas diferentes ramificações esquematizam toda a distribuição de terrenos gnáissico-mig matiticos e suas alternâncias com as bandas metassedimentares da ảrea do Maciço de Caldas Brandão.

No interior do Ceará, a preservação de värios schist belts do Sistema Jaguaribeano é condicionada ao acionamento de falhas profundas ("Jaguaribe", "Orós", "Limoeiro", "Senador Pompeu", etc.) desta ordem. Os 1 ineamentos de Sobral e Jaguarapi definem limites abruptos para o Sistema Mëdio Coreau e os maciços adjacentes, e ao longo desses limites se desenvolveram bacias que foram entulhadas por sedimentos molâssicos, como jả visto.

Vârios outros exemplos de segmentação geotectônica primâ ria podem ser apontados, dedutíveis da observação dos grandes mapea mentos regionais e da anālise de imagens de radar e satélite.

Esta constatação elementar conduz a uma dedução de idade bem antiga para estas estruturas, que remonta provavelmente ao Pro terozóico Inferior, pelo menos.

Embora o problema de idade da sedimentação dos sistemas de dobramentos seja reconhecido, hả evidência de efetiva movimentação das zonas de sutura durante os processos sedimentares e vulcano-sedimentares.

A presença de quartzitos, metabrechas e metaconglomerados, bem como a presença de metavulcânicas (como em Aurora, Martinópole, 
etc.) alinhados consoantes estas estruturas $\vec{e}$ un atestado de ativi dade sinsedimentar destas zonas de fraqueza.

Já nas fases principais de criação de estruturas tectöge nas é comum encontrar o traço destes lineamentos (ou parte deles)de limitando e anteparando o sentido da vergência, apresentando para isto feições de falhas inversas, como acontece no Sistema Pajeü-Paraiba, por exemplo (SANTOS, 1971).

Nas fases tardías da tectogênese brasiliana instalaram-se ao longo dos lineamentos de Pernambuco (granitóides tipo "Moderna") e de Patos (tipo "Catingueira") rochas graniticas de filiação alca lina, que foram posteriormente afetados por movimentos de transcor rência. Ao longo do lineamento de Sobral (Falha Cafë-Ipueiras) os granitos de Meruoca e Mucambo se acham alocados, em flagrante cara ter epizonal, mas suas bordas tambën são seccionadas pelas falhas desse sistema. Värios outros exemplos podem ser adicionados, ratificando portanto manifestas fases de alivio, antecedendo de forma clara a fase (ou fases) de rejeito direcional.

A fase principal de transcorrência, que sucede a coloca ção de granitos jä mencionada, também se mostra posterior à fase principal de dobramentos (da xistosidade) dos sistemas. Assim ë que a transcorrência impõe deformações e arrastos nas dobras pre existentes, havendo alguns deslocamentos da ordem de dezenas de qui lômetros. Concomitantemente é sobreposto metamorfismo dinâmico às diferentes texturas metamörficas dantes elaboradas.

Hã razões de sobra, em face da dimensão da região e o nú mero de falhas profundas, para se admitir não sincronia de todos esses movimentos horizontais. Em alguns lineamentos, como o de Sobral, hä registros geológicos patentes de recorrência dos movimen tos direcionais, inclusive no Fanerozöico.

Via de regra movimentos transcorrentes geram rochas de fo liação pröximas da vertical. E muito comum se encontrar a foliação dos grandes 1 ineamentos (Serra das Russas, Senador Pompeu, etc.) de formada de värias maneiras, deslocadas ruturalmente e mesmo dobra das, consoante fases sobrepostas ainda não devidamente pesquisadas e compreendidas, mas que endossam o caräter de grande mobilidade sediado ao longo dos 1ineamentos (vide AGRAWAL, 1981).

$\mathrm{Na}$ fase final do Prë-Cambriano e início do Paleozóico, 
hâ registro, em partes destes lineamentos, da presença de componen tes gravitacionais. As coberturas dobradas de caräter molássico (Jaguarapi, Jaibaras, Cococi, São Julião, Iara, etc.) são preserva das e condicionadas estruturalmente por movimentos verticais ao lon go de parte desses lineamentos. E, alguns desses "grabens" é certo que os movimentos verticais atingiram milhares de metros de rejeito.

Ao longo do Fanerozöico, novamente hä evidências de ação dos lineamentos em mais de uma etapa, mas com maior ênfase ao longo dos processos da chamada Reativação Wealdeniana. O jogo de blocos separados por estas zonas de falha deprimiu äreas do embasamento que aprisionou parte das coberturas paleo-mesozöicas, ao mesmo tem po que condicionou altos estruturais de diferentes dimensões, rapidamente dissecados pela erosão.

As frações de uma pretërita e ampla bacia sedimentar se espalham na porção centro ocidental do Nordeste, consoante a mecân ca de blocos falhados e os caprichos da erosão, a saber: Iguatū, Ma Ihada Vermelha, Icó, Lima Campos, Lavras Mangabeira, Rio do Peixe, Araripe, Belmonte, etc. que serão objetos de análise posterior.

A mais imponente presença de falhas normais no seio dos lineamentos é o caso de Ibimirim, pernambuco, que delimita a norte a Bacia de Jatobä, onde o rejeito conhecido suplanta $2000 \mathrm{~m}$.

$\mathrm{Na}$ projeção para o substrato da Bacia do Paraíba dos $1 \underline{i}$ neamentos de Sobral e de Patos, são encontradas värias emanações de rochas bäsicas (COSTA et a1., 1973; SIAL, 1975), como expressão da Reativação Wealdeniana. Estes processos magmáticos cratogênicos se desenvolverão em mais de uma etapa do tempo geológico (CALDASSO e HAMA, 1980), do período mesozóico. CUNHA e CARNEIRO, 1971, adu zem considerações à viabilidade de movimentos transcorrentes no $1 \underline{i}$ neamento de Sobral, durante o Mesozóico,inclusive.

Todas estas observações, de cunho muito amplo e da escala de reconhecimento, são necessárias para evidenciar o policíclismo dos lineamentos, no tempo geológico e nos tipos de rejeitos. Todas elas demandam re-exame em outras escalas, e a falta de maior profun didade no conhecimento $\hat{e}$ a tônica de todas elas. E preciso reconhé cer que assertivas tão vagas sobre realidade assim contundente não 
$\vec{e}$ apanägio da região Nordeste, ou do nosso país (vide região Sudes te). Desde os trabalhos introdutörios destes conceitos, na Europa (CLOOS, 1948; PEIVE, 1960), ainda na voga absoluta do "fixismo", até os dias atuais, verifica-se progresso insatisfatörio conhecimento concreto destes tipos de estruturas. Algumas sugestões recentes, den tro da tectônica mobilista, procuram enfatizar estas falhas como lu gar geomētrico de confronto de placas litosféricas (tipo conservatí vo) SUTTON e WATSON, 1974 admitem atuação, em algumas instâncias destas geofraturas como falhas transformantes no interior de mas sas continentais. DAVIES e WINDLEY, 1976, compararam a idade de a 1 guns desses falhamentos conhecidos como a idade de quebras maiores das curvas aparentes de migração polar aparente para América do Nor te e Africa, e destacaram grupos de $1000-1300$ m.a. e 1700 m.a., e os interpretaram como expressão de quebras continentais (e even tual formação do Proto-oceano Atlântico). Alëm disto, estes auto res admitiram que tais lineamentos são, em geral, subparalelos às estruturas dos terrenos granito-greenstone, e poderiam ter sido in fluenciados primariamente pelo arcabouço do Arqueano. Outras con cepções mais arrojadas (MOORES, 1981, etc.), de fundo teörico, são conhecidas, e mais e mais elas reforçam a necessidade inadiāvel de seu aprofundamento geolögico e geofísico no estudo destas falhas fundamentais. 


\section{0 - A COBERTURA FANEROZOICA}

\section{1 - ANALISE PRELIMINAR}

De forma inusitada e característica, o Nordeste Oriental do Brasil, e palmilhado por esparsas coberturas do Fanerozöico, en cravada no seu embasamento, sem paralelos em qualquer outra parte do Brasil, nem mesmo na contraparte africana.

A Bacia do Parnaíba (a oeste) e a provincia sedimentar costeira (do Piauí à Bahia) foram, por definição tomados como limi tes convencionais da Provincia Borborema. Em verdade, não podem constituir limites de fato, haja vista que estas coberturas jazem sobre estruturas brasilianas $\mathrm{d}_{a}$ Borborema e são fortemente influen ciadas por elas. Extensões destes desenvolvimentos sedimentares (e provavelmente partes de outras bacias intracratônicas desaparecidas) penetram de forma imponente esta fração setentrional do escudo atlân tico, de forma contínua ou descontinua, quase sempre condicionada por imposições tectônicas do embasamento sotoposto.

Estas coberturas sedimentares do interior da província em nenhum momento constituem obstāculo à continuidade de observação do embasamento. Tanto pela expressão territorial (modesta em geral), quanto pelo condicionamento tectônico herdado. Muitos dos limites destas coberturas se devem à reativação gravitacional de suturas prë-cambrianas assim como a pröpria disposição geomëtrico-estrutural assumida pelos litossomas (monoclinais simples, graben-sinclinais, blocos basculados, etc.) têm causa idêntica.

Nessas "bacias" interiores, como usualmente são chamadas, hä falta sistemätica de dados de subsuperfície, ou eles são extrema mente restritos. O quadro lito-estratigráfico haurido nas expres sões de superfície carece de revisão drâstica nos três ramos da es tratigrafia, pois são muitas as inferências e deduções por compara ções à distância, em escala de caräter exploratório.

$\mathrm{Na}$ provincia costeira, e nos"rifts"interiores a ela asso ciados a documentação estratigráfịca é farta e de boa qualidade, sem ser irretocável, graças principalmente aos trabalhos da Petrobrās. Apenas na fração do saliente oriental do Nordeste (Natal - Recife Barreiros), que parece ter exercido papel de alto estrutural na evo lução da margem do continente, as informações estratigräficas são 
ainda deficientes. O quadro de subsuperficie demanda refinamento, uma vez que as coberturas terciärias reduzem a um minimo as secções mais completas.

As observações sobre esta contexto estratigráfico do Fane rozóico serão feitas com objetivo de sintese do conhecimento atual, para o qual o prisma da geotectônica (sequências sedimentares cratô nicas) parece o mais adequado. Uma prolifera bibliografia especia lizada preexiste e deve ser procurada para aspectos que escapam à abordagem de reconhecimento aqui ensejada.

Desta forma são reconhecidos e serão discutidos prelimi narmente oito distintos contextos 1ito e crono-estratigräficos, in tercalados por discordâncias, que preenchem requisitos de sequên cias cratónicas interiores e da margem do continente, e que se acham presentes nos diferentes tipos de bacias sedimentares propostos no Quadro 10.1, anexo.

\section{2 - SEQUENCIAS SEDIMENTARES CRATONICAS}

A) As coberturas fanerozöicas mais antigas - cambro - ordo vicianas - constituem registros de fases deposicionais corresponden tes aos movimentos tectónicos (e ao magmatismo) do epílogo do Ciclo Brasiliano, donde adveio a conceituação de molassas (ALMEIDA, 1969) ou de depósitos pós-tectônicos. Esta conceituação (Sequência I de ALMEIDA op,ct.) como depósitos do estägio de transição para condi ções cratônicas tem sido frequentemente enriquecida com o advento de novos dados - lito-estratigráficos, geocronológicos, etc. Novas ocorrências destes depösitos têm sido descobertas, nesta dêcada, in clusive, e sempre dentro das características gerais a serem sintet $\vec{i}$ zadas a seguir.

Os sitios deposicionais destas coberturas, em todos quadrantes da região são relíquias de uma extensão pregressa difí cil de reconstituir. Todos eles mostram controle absoluto das ca 1has mais profundas, adjacentes às geofraturas e proteção sistemāt ca da cobertura siluro-devoniana, como circunstanciadores da sua preservação.

Alèm destas, outras características, discutidas anterior mente podem ser sumariadas:

a) Discordância angular e erosiva na lapa (metamorfitos 
Qunks) lit.

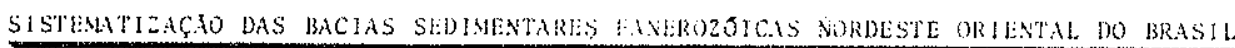

1. "BACIAS" LUPALEOZOICAS ("RIFTS" POS-TECTONICOS)

Jaibaras, Jaguarapi, Ubari

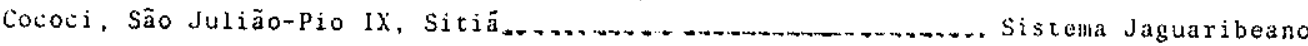

lira

Jü̈, Palnares....... Sistema Sergipano

2. BACIAS PALEOZOICAS E MESOZOYCAS INTERIORES

CUATONICAS INTERIORES

Parnaíba

Rift Reconcavo-l'ucano-jatobä

(vinculado à Província Costeira)

ARARIPE - SAO JOSE - BELNONTE - SANTO IGNACIO

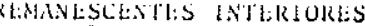

(conexöes discutíveis)

Alto Piranhas

$\mid \begin{aligned} & \text { Rio Nazare (Encanto) } \\ & \text { Triunfo-Brejo das Freiras-Pombal } \\ & \text { (Rio do Peixe) }\end{aligned}$

Mëdio Jaguaribo

lguatu-Malhada Vermelli:

Lima Campos

ICO

Lavras do Mangabeira

Iborepi, etc.

Afogados da Ingazeira
Betania-Carqueja
yirandiba

\section{RIFTS COSTELROS- PROVINCIA COSTEIRA E NARGEM CONTINENTAL}

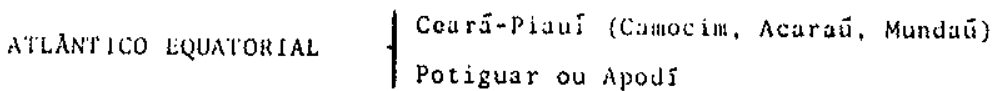

SALIENTE ORIENTAL ("alto" intermediärio)

Sub-bacia Norte (RN - PB)

Sub-bacia Centro (Recife - João Pessoá)

Sub-bacia Sul (Sul do Recife)

ATLANTYCO CENTRAL

t Sergipe - Alagoas

OBSERYAÇAO:

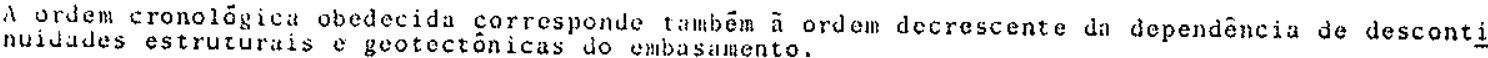


brasilianos) e capa (sedimentos siluro-devonianos).

b) Compostos substancialmente de clästicos grosseiros ter rígenos, brechas e conglomerados polimícticos, variegados, de depo sição subarëa e subaquätica, proveniente de relevos pröximos, brus camente juvenescidos.

c) Sempre hâ evidências do crescimento (latero-vertical) gradativo na seleção das unidades basais, culminando com depósitos terrigenos lacustrinos (siltitos, folhelhos), e atë mesmo bancos de carbonatos. Retomadas episỏdicas, e mesmo a volta de condições ex tremas de sedimentação continuam a ocorrer.

d) Uma ou mais fases de magmatismo, intermediärio e bäs $\underline{i}$ co, são de registro comum, em fácies extrusiva e intrusiva, princi palmente.

De recentes estudos levados a termo na Bacia do Parnaiba, a serem comentados, surgiu a possibilidade de reconhecer neste tipo de sequência os depösitos dos rifts precursores dos processos intra placas de formação de sinëclises. Mas esta é uma linha de pesquisa que necessita muito apoio de dados de subsuperficie, imprescindivel para o futuro.

B/C) As coberturas do Paleozóico do interior do Nordeste indicam uma tendência a abaixamento generalizado da província re cëm-cratonizada na sua porção central e sul oriental. As feições de limites por falhas, basculamentos, etc. devem ser creditadas à sobreposição da tectônica do Cretäceo. Em geral, são unidades 1ito-estratigráficas monótonas e pouco espessas, que guardam muitas simi laridades de uma ocorrência à outra, indiferentes às distâncias pro duzidas pela conjugação da tectônica e da erosão pós-Permiano. Embó ra, com carência de dados, há razóes suficientes para se admitir muí to pouco diacronismo destes 1itossomas com as linhas do tempo, e ações moderadas e amplas dos processos de subsidência.

De forma que se pode reconhecer, tanto nas ocorrências iso ladas como no assoalho de alguns dos "rifts" da provincia costeira, a validade dos ciclos tecto-sedimentares cratogênicos preconizados para as grandes sinëclises paleozóicas.

B) Paleozóico Inferior

-Eodevoniano-Carbonifero Inferior $\left\{\begin{array}{l}\text { ALMEIDA, } 1969 \\ \text { Sequência Gama de } \\ \text { SOARES, FULFARO e } \\ \text { LANDIM, 19.74. }\end{array}\right.$ 
C) Paleozöico Superior

- Permo-Carbonifero

$\left\{\begin{array}{l}\text { Sequência II d de ALMEIDA, } 1969 \\ \text { Sequência Delta de SOARES } \\ \text { FULFARO e LANDIM, } 1974\end{array}\right.$

Apesar da desestabilização conferida a estas coberturas,pe la tectônica que precedeu, assistiu e estabeleceu a margem do conti nente, é possivel rastrear, e se aproximar bastante do panorama pá leogeogräfico alcançado por estas sequências. A segunda sequência extrapola os limites da primeira, e marcando a ampliação do seu sí tio deposicional observa-se uma discordância erosiva em continuida de regional.

A sequência "A" parece ter-se limitado ao sul pelo alto estrutural balizada pelo Rio Vaza Barris-zona de dobramentos de pro pria - cujas características ja foram enfatizadas. Para noroeste se pode acompanhar o desenvolvimento desta sequência na direção da Bacia do Parnaíba. E muito provável que as ocorrências do Nordeste sejam partes de um antigo eixo de subsidência NW-SE, Tianguá-Jatobá (proposto por AGUIAR, 1971) da Bacia do Parnaíba, precocemente in vertido, cujas ruínas são hoje tentativamente relacionadas. A pré sença de um amplo ciclo transgressivo-regressivo, contando com for mações marinhas (Inajā, Pimenteiras/Longā) plenamente correlaciona veis é diagnóstico de peso neste aspecto, e na proposta formulada de quiescência tectônica, com subsidência ampla e regularmente dis tribuida (plataformal).

A sequência "C" estendeu-se mais para sul e sudeste, com relíquias hoje preservadas por todo "rift" Recôncavo-Tucano-Jatoba, Sergipe e homölogos africanos, e na Bacia do Parnaíba. Não hã pre servação (ou não foi identificada) na porção central do Nordeste. Mas a correlação estratigräfica é boa entre os restos conhecidos, a testando condições de grande estabilidade tectônica (sem incursões marinhas) predomínio de sedimentação continental, inclusive diamic titos e ritmitos värvicos. São conhecidos apenas dados de inf1uên cia marinha na Formação Pedra de Fogo, na Bacia do Parnaíba.

D) A discordância que se segue à sequência anterior, re trata tambëm o amplo hiato Triảssico-Jurässico Inferior e Médio, no 
Nordeste como no Brasil.

Do final do Jurässico e início do Cretäceo (GHIGNONE, 1977 ; NETTO, 1978) - andar Dom João - ë possível reconhecer nova sequên cia sedimentar sincrônica ao soerguimento das äreas dômicas que se instalaram na atual zona costeira, prefaciando o rompimento conti nental. Os sedimentos clásticos continentais (Grupo Brotas) são comuns das depressões inter-domos, do Brasil e da Africa, acham-se também representados no interior do Nordeste (Mirandiba, Araripe, Belmonte, etc.). Estes depósitos são restos dos sedimentos da am pla "Depressão Afro-Brasileira", reconstituída por PONTE et a1., 1971, cujo contexto lito-estratigräfico não marinho (coalescência de leques aluviais), é hoje reconhecido como importante sequência intracratônica. Em parte corresponde a sequência De1ta-A de SOARES, FULFARO e LANDIM, 1974 ou ainda ë representativa do estägio "prërift" de ESTRELLA, 1972.

E) Os registros sedimentares do Cretäceo Inferior pre-Aptiano são típicos de processos "rift valley", condicionados e ali mentados por falhas marginais, com sedimentação clästica lacustre, bordejada por leques deltäicos. Este tectonismo intenso e a sedi mentação associada tem franca representação nas bacias interiores do Nordeste e cenärio prototípico na Província Costeira (Supergrupo Bahia, Supergrupo Baixo São Francisco, partes média e superior). Cor responde à "Sequência dos Lagos", na moderna concepção de ASMUS é GUAZELLI, 1981, ja vislumbrada por ALMEIDA, 1969 (parte da Sequên cia IV), ESTRELLA, 1971 (estägio de "rift"), e discutida por dive $\underline{r}$ sos outros autoreś em värias oportunidades.

As ocorrências conhecidas no Nordeste (Ki no mapa geolögi co) fora da Província Costeira, são restritas ainda (Grupo Rio do Peixe), mas isto pode ser produto apenas do nível insatisfatório do conhecimento da subsuperfície.

F) No Aptiano-Albiano, após o arrefecimento da fase de "rift" e do ciclo erosivo subsequente, houve a implantação de impor tante e extensivo ciclo tecto-sedimentar no continente brasileiro, em fase de individualização. Trata-se da mais ampla etapa de sedi 
mentaçäo plataforma conhecida na coluna estratigräfica em condiçöes de grande estabilidade tectônica, impondo-se sobre os antigos "rifts" assoreados e ultrapassando em muitos os seus limites. O predomínio é de sedimentação continental (fluviatỉl, lacustre), com conexões circunstanciais com o oceano, advindo fảcies de āgua salôbra e eva poritos. Pela importäncia e extensividade destes sedimentos no Nor deste, reclama-se um destaque na coluna lito e crono-estratigräfica $\left(k_{i j}\right)$, como secção mëdia do Cretäceo, formulada no mapa milionésimo anexo.

Parte desta sequência tem sua caracterização bem estudada e discutida na Província Costeira, como Sequência do Golfo (ASMUS e GUAZELLI, op.cit.), entre vārias outras denominações precedentes, referente ao estägio proto-oceânico, onde são comuns intervalos de evaporitos e folhelhos negros (Formação Muribeca, por exemp10). Es te peculiar evento "tempo-rocha-tectónica" do interior do continen te, distinto daquele impingido às zonas de oceano nascente foi pri meiramente discriminado e proposto por GHIGNONE, 1972, como "Sequên cia $V^{\prime \prime}$, que merece franca e ampla ratificação.

G) As invasões marinhas do Cretáceo Superior e Terciärio Inferior ("Sequência $V$ " de ALMEIDA, 1969, em parte;"Sequência do Mar", ASMUS e GUAZELLI, 1981, entre outros) tem sua representação bem caracterizada nas bacias costeiras, e em Sergipe representação prototípica a ser enfatizada.

No interior do Nordeste, iniciou-se nesta época uma fase de eventos generalizados de soerguimento epirogenético e não hâ da dos concretos de sedimentação marinha e apenas hä alguns dados dis cutiveis (depösitos correlativos da "Superfície Post-Gondwana") de sedimentação continental.

H) A atividade epirogenëtica que atuou nesta região de escudo no Cretäceo Superior e Terciärio foi complexa (värios focos) e generalizada, e foi seguida de intensa e policíclica reação glip togenētica, discutida por värios autores, compondo prolífera termi nologia. Depösitos sedimentares albo-aptianos, de āgua salôbra,são hoje encontrados acima de cotas de $700 \mathrm{~m}$, o que atesta a importân 
cia dos movimentos ascencionais dessas épocas.

Os processos morfogenéticos favorecem a formaçāo de exten sas e finas capas sedimentares arenosas, de convexidade voltada pa ra baixo. São muito desgastadas pela sanha erosiva do ciclo atual ("Paraguaçü"), e jazem coroando frações de pediplanos, sobre rochas sedimentares mais antigas, sö alcançando certa continuidade pröximo às zonas costeiras. Estes sedimentos, do Grupo Barreiras s.1. e crono-correlatos os sedimentos colüvio-elüvio-aluvionares cenozöi cos e os depósitos de praia e conexos estão reunidos numa ampla edescontínua "Sequência", reconhecida por unanimidade por ALMEIDA (VI, Pös-Eocênica), GHIGNONE (VI) e SOARES, FULFARO e LANDIM (Zeta), autores $j \vec{a}$ mencioandos.

A estabilidade tectônica posta em evidência para esta se quência não impede que os litossomas tabulares por ela consubstan ciado tenham sido usados com certa frequência para espelhar movimeñ tações tardias ruturais das rochas subjacentes.

\section{3 - ATIVIDADE MAGMATICA POS-SILURIANA ASSOCIADA}

Dois estägios distintos de atividade magmätica basāltica, no Pös-Siluriano, são considerados associados aos processos de for mação/reativação de cobertura sedimentar.

o primeiro estägio, melhor representado no mapa, ë o en xame de diques E-W do sul da Bacia Potiguar, de idade Cretācea (Kdb). o segundo grupo é predominantemente composto de älcali-basaltos, in clui formas intrusivas e extrusivas, em äreas esparsas do Rio Gran de do Norte e da Paraíba, e é de idade terciäria (Tdb).

Associados ao primeiro grupo, de certa forma nas causas tectônicas e no tempo, devem ser mencionadas as hipoabissais e in trusivas (diabāsios, dioritos, tonalitos) da Província Parnaíba (Jdb), instalados por toda borda leste, principalmente na projeção dos li neamentos Patos e Sobral (Vulcanismo Sardinha). Ainda neste grupo do Mesozöico devem ser consideradas as rochas vulcânicas (Grupo Per nambuco) da Sub-bacia Sul do Recife e o granito do Cabo. Todas es tas manifestações magmäticas cratogênicas são reflexos da reorgani zação tectônica impingida pelos processos de formação do Atlântico.

o enxame de diques do Rio Grande do Norte - "alinhamento 
Cabugi" - estende-se em parte dos Estados da Paraíba e do Cearả, sendo composto por olivina diabäsios, diabäsios toleíticos, augita-diabásios (e basaltos). Valores de idade K/Ar referidos por SIAL, 1976, indicam idades entre 125 e $135 \mathrm{~m} . \mathrm{a}$. Mais ao sul, na "Bacia" de Lavras da Mangabeira (Cearā), PRIEM et a1., 1978, identificaram augita basaltos intercalados na secção sedimentar com idades K/Ar entre 169-180 m.a. (Jurässico Médio).

As rochas do segundo grupo ocorrem ao longo e a oeste do meridiano $36^{\circ} \mathrm{W}$ ("trend" $\mathrm{N}-\mathrm{S}$ ), formando "plugs", diques e derrames de tipos ankaratitos, basanitos e olivinas basaltos. Parte destes derrames recobrem depósitos cenozóicos, como em Boa Vista, Cubati, etc. (Formação Boa Vista) preservando-os da erosão. Na Bacia Po tiguar hä värias incidências de olivina basaltos, afaníticos a ve sicular, cortando rochas da sequência sedimentar, inclusive do Ter ciärio. Valores de idade K/Ar entre 42 e 18 m.a., em rocha total, foram referidas por SIAL, 1976, e portanto dentro do Paleógeno.

Nas imediações ao sul de Fortaleza são conhecidos värios pequenos "necks" e "plugs" e diques alcalinos, constituídos de fo nolitos e traquitos nefelínicos. A idade radiométrica dessas ro chas (W. TEIXEIRA, 1981; SIAL, 1976) encontra valores de 26 a 34 m. a .

A interpretação de vulcanismo do Paleógeno como ativida de intraplaca envolve ainda muitas especulações ("hot spots", "fra turas oceânicas", etc.), mas não hả dados concretos.

Afora estas ocorrências mais divulgadas, e nem sempre cartografäveis, hä varias outras, por todo o domínio centro-orien tal, mapeados por alunos e professores do Curso de Geologia do Re cife, em diversas oportunidades, nas quais faltam indicações geo cronológicas. Uma revisão no problema, na escala regional, jä se faz necessärio,para uma interpretação mais abrangente e atual, inclusive com relação às sequências sedimentares cratônicas( "E" ,"H") com que estas rochas vulcânicas se acham associadas. 


\section{1 - AS BACIAS/PROVINCIAS SEDIMENTARES}

\section{1 - A BACIA (PROVINCIA) DO PARNAIBA OU MARANHAO-PIAUT}

\section{1 .1 - Aspectos Geológicos Gerais}

A Bacia do Parnaíba por si só configura uma das propostas provincias estruturais brasileiras (ALMEIDA et a1., 1977), acha-se localizada no chamado Nordeste Ocidental do Brasil. Trata-se de uma típica bacia cratônica (BALLY e SNELSON, 1980) ou ainda de uma ba cia intracratônica de interior remoto (PORTO e SZATMARI, 1982), den tro das concepções modernas de classificação.

$\mathrm{Na}$ verdade, a dependência desta província de cobertura pa leozóica das estruturas brasilianas, em geral, transcede a qualquer esquema de classificação. Funções tais que origem, evolução paleo geogräfica, posição de depocentro e ärea fontes, forma atual,tratos geomōrficos, etc. podem e têm sido interpretadas como dependentes diretas do arcabouço legado pelo Ciclo Brasiliano.

Em particular, o flanco oriental desta entidade, represen tada no mapa, enfatiza a importância das linhas estruturais situa das na ou egressas da Província Borborema. A condição de limite entre províncias atribuídas a esta margem de erosão atende somente razões descritivas, e uma instância cenozóica.

A porção leste (Serra de Ipiapaba) da Bacia assenta e obe dece traços de foliação do embasamento (e da falha de Tauã), e toda a borda sudeste se condiciona à projeção do lineamento de Senador Pompeu. Esta flanco oriental funcionou como um patamar monoclinal de fraco mergulho, basculado para $W-N W$, contra o lineamento trans brasiliano (Sobral, Guaraciaba) que é o lugar geométrico de espessa mento mäximo das sequências paleozöicas e de ocorrência preferen cial dos depósitos cambro-ordovicianos (Jaibaras, Jaguarapi, Monte do (armo-G0). Durante os processos de reativação wealdeniana, nova mente as estruturas brasilianas secantes à bacia voltaram a ser efe tivas, canalizando intrusivas ígneas bäsicas (Vulcanismo Sardinha) e posteriormente definindo os grandes tratos morfoestruturais ter ciārios. 


\section{1 .2 - Desenvolvimento Lito-Estratigräfico}

Na porção da bacia cartografada é excelente a representa ção das primeiras sequências sedimentares da então recém-consolidada plataforma sulamericana.

As unidades cambro-ordovicianas foram referidas em. värias porções da periferia da bacia, em projeções para seu substrato ( Jai baras, Ubari, Jaguarapi, Cococi, São Julião, etc.). Unidades de $\underline{s}$ te tipo acompanham todo o lineamento transbrasiliano, de nordeste (Jaibaras) para sudoeste (Monte do Carmo-Goiás) preenchendo autênti co depocentro/graben, considerado precursor da pröpria Bacia do Par naíba (CORDANI et a1., em preparação).

O Grupo Serra Grande apresenta um perfil essencialmente de clásticos (até $1000 \mathrm{~m}$ ), grosseiros, médios e finos, materializan do uma progradação de sedimentação fluvial para deltãica, com locali zadas interveniências marinhas.

A Formação Pimenteiras (bem como a Formação Longã) é com posta essencialmente de folhelhos com intercalações de arenitos fí nos, numa secção (atê $400 \mathrm{~m}$ ) típico do alcance de condições mar nhas francas. Influências deltäicas e fluviais são restritas.

A Formação Cabeças grada (vêrtico-lateralmente) para suas encaixantes, apresenta perfil essencialmente de arenitos finos e siltitos (mëdia de $200 \mathrm{~m}$ ), e representa, segundo CAROzzI et a1., 1975, um sistema de deltas coalescentes e sedimentação marinha.

A Formação Poti encerra o ciclo tecto-sedimentar, com per fil variado de clästicos, grosséiros, mëdios e finos, algumas len tes calcárias e restos vegetais. Mostra o retorno gradativo e in termitente às condições continentais. Seu contato com unidades do ciclo tecto-sedimentar seguinte (do Permo-Carbonífero) mostra evi dências de discordância erosiva.

Alguns depósitos sedimentares terciärios (TQC). podem ser observados entre o Rio Poti e a região de Simplício Mendes.São clás ticos continentais, arenitos arcosianos, produtos da evolução geo mórfica "VI"ou"zeta" do sítio colocado entre os lineamentos trans brasilianos e de Senador Pompeu. 


\section{2 - A PROVINCIA COSTEIRA}

\section{2 .1 - Bacias Tucano/Jatob $\vec{a}$}

\section{A) ASPECTOS GEOLOGICOS GERAIS}

A colocação destas entidades como partícipes da Provín cia Costeira, na proposição de ALMEIDA et a1., tem razões superio res de escala de analise. Embora se tratem de estruturas secantes da Província Borborema (e do Craton do São Francisco), o seu víncu 10 como aulacógenos oriundo dos processos de formação da margem continental parece inquestionável, e definitivamente assentado por PORTO e SZATMARI, 1982.

Ao longo do seu desenvolvimento estes "rifts" receberam marcante e bem diferenciado controle da natureza e estrutura do substrato précambriano. Além disso, incorporaram na sua coluna 1ito-estratigräfica retalhos da sedimentação prëcambriana e fane rozóica prëexistentes de distintos procedencia e significado geo tectônico.

A Bacia de Tucano tem direção geral norte-sul, forma alon gada, de losângos justapostos, cujas junções são altos estrutu rais interiores. Sua ärea total soma cerca de $23000 \mathrm{~km}^{2}(330 \mathrm{x}$ $50-100 \mathrm{~km}$ ), impondo-se diagonalmente do Craton do São Francisco(B1o co da Serrinha) para a Província Borborema(Sistema Sergipano e Ma ciço Pernambuco-Alagoas). Seus altos interiores, subdividindo a ba cia, tem proveniência de estruturas do embasamento.

o alto de Aporá (ao sul do mapa) se orienta segundo a di reção do cinturão granulítico AtIântico (NE-SW), serve de divisa com a Bacia do Recôncavo. O Alto do Vaza Barris que separa os se tores Norte e Centro de Tucano reflete estruturas sotopostas da "Zona Geanticlinal de Propriä". O Arco de São Francisco, que sepa ra Tucano Norte de Jatobā perlonga a zona axial do maciço Pernam buco Alagoas. Outras zonas de falhas do embasamento (Macururé, São Miguel Aleixo, limite norte do Craton do São Francisco, etc.) tam bëm influenciaram a evolução estrutural e paleogeográfica deste "rift", e no presente mostram consistente interferência nos pa drões geomórficos observados. 
Do ponto de vista estrutural, Tucano apresenta uma suces são de grabens/sinformais assimëtricos, dispostos na direção $N-S$. Ao sul do Vaza Barris, as unidades mesozóicas afloram na borda oeste, com mergulho suave $\left(0\right.$ a $\left.10^{\circ}\right)$ contra a falha do flanco orien tal. Ao norte do Vaza Barris, as unidades paleozóicas e mesozói cas afloram na borda leste, e mergulham suavemente contra o flanco ocidental. A complexa trama estrutural com esta resultante pode ser estimada na observação da direção das pequenas falhas que per longam as bordas da bacia.

A Bacia de Jatoba tem uma forma elíptica, cujo eixo maior $(155 \mathrm{~km})$ tem direção E-NE, perfaz uma extensão da ordem de 6000 $\mathrm{km}^{2}$. Seu limite norte $\bar{e}$ a falha de Ibimixim, com rejeito supe rior a $3000 \mathrm{~m}$, e que se instalou colinear ao Lineamento Pernambu co. Suas bordas sul e leste exibem monoclinal de fraco mergulho $\left(5^{\circ}\right.$ e inferior), com "cuestas" de erosão.

A brusca mudança de direção de N-S (Tucano) para ENE-WSW (Jatobä) do sistema de "rifts" cretäcicos, assim como as diferen tes atitudes monoclinais de seus diversos setores, parecem impos tas pela estruturação do embasamento, e de suas descontinuidades geotectônicas.

De modo geral estes dominios sedimentares esmeram uma morfologia de pediplanos arenosos extensos, com cotas dominantes na ordem de $300-400 \mathrm{~m}$. Esparsos patamares mais resistentes, em função de aspectos litológicos (calcārios, níveis silicificados) e tectônicos ("hog backs", falhas) tangenciam níveis de 700-900 m.Ex tensos areais e vegetação arbustiva caracterizam a paisagem destas bacias.

\section{B) DESENVOLVIMENTO LITO-ESTRATIGRAFICO}

No assoatho do "rift" Recôncavo-Tucano-Jatobă, as prime i ras coberturas sedimentares a mencionar são do Proterozóico Supe rior, do Grupo Estância, ali retidas por circunstância da tectôn ca do Cretäceo. De forma idêntica, restos de depósitos cambro-or dovicianos, Juá, Palmares e assemelhados, têm sido identificados em testemunhiagem profunda.

A sequência do Paleozóico Inferior se faz presente ape nas em Tucano Norte e Jatobä, com considerävel expressão 1ito-e 
tratigräfica.

A Formação Manari/Tacaratu (SDt), de idade Eodevoniana, é essencialmente arenosa e conglomerätica, com espessuras de 250 $-300 \mathrm{~m}$, retrata ambientes fluviatís e lacustrinos (forte componen te caulínica) de uma associação transgressiva.

A Formação Inaj $\vec{a}$ (Di) jă reủne litologia e fauna tïpica de mares epicontinentais rasos. Ha predominância de clästicos fi nos, arenitos, siltitos e folhelhos (ate $400 \mathrm{~m}$ espessura).

Sobreposto à Formação Inajā, de idade devoniana inferior, no poço de Ibimirim-PE foi encontrada uma unidade de folhelhos mi cáceos escuros e arenitos mẻdios e grosseiros, com cerca de $270 \mathrm{~m}$ de espessura, e que BARRETo, 1968 designou de Formação Ibimirim, ainda de idade devoniana. No mesmo poço, sobre a Formação Ibimi rim ocorre uma unidade composta de arenitos finos, folhelhos e sil titos, com intercalações calcärias, com cerca de $150 \mathrm{~m}$ de espessü ra, a que BARRETO (op. cit.) designou Formação Moxotó, de idade eocarbonífera, em acordo com ALMEIDA, 1967. Os dados palinológi. cos conhecidos mostram equivalência entre as Formações Longā e Ib mirim, e entre Poti e Moxotō, das Bacias do Parnaíba e Jatobá, res pectivamente, segundo ALMEIDA, 1967 (op. cit.).

No flanco leste de Tucano Norte e Jatobả hä outras res tritas e importantes relíquias da sedimentação permo-carbonífera do Nordeste. A Formação Curituba (Cc) é constituída de folhelhos, contendo intercalações de arenitos e calcários, e värias analogias com o Membro Boacica da Formação Batinga, da Bacia Sergipe-Alagoas.

A Formação Santa Brígida (Psb), de idade permiana, é constituída por arenitos feldspäticos e folhelhos escuros, com fi nas camadas de silex (e apresenta sintomätica analogia com a Forma ção Aracarë da Bacia Sergipe-Alagoas). Por todo "rift" Recôncavo-

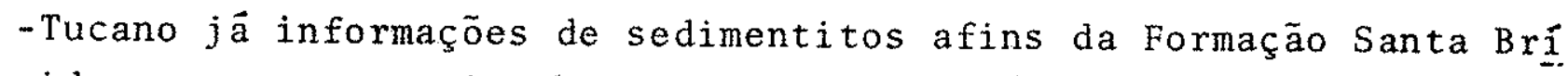
gida, no contexto lito-bio-crono-estratigräfico. Em grande parte, estas 1itologias estão mapeadas incorporadas no Membro Afligidos, inferior da Formação Aliança, mas que estão em fase progressiva de discriminação atualmente.

O Grupo Brotas (Jbs) ocorre (Reconcavo-Tucano-Jatobä, Ma randiba, Araripe, etc.) dentro de suas características típicas da 
sua extensa ärea de ocorrência afro-brasileira, e esta cartografa da indiviso por värias razōes, estratigräficas, tectônicas e de es cala. A Formação Aliança é composta por folhelhos verdes e verme lhos, com intercalaçōes placosas de calcärios, e gradações para are nitos vermelhos. A Formação Sergi $\vec{e}$ composta por arenitos quart zosos, avermelhados, de grã variāvel, com freqtente estratificação cruzada e restos vegetais silicificados. Trata-se de um pacote que espelha sedimentação predominantemente subaërea, de värias ambiên cias fluviatís.

A "Sequência do Petröleo" (Ksp), ê a designação informal proposta por NETTO, 1978, e aqui adotada (engloba os Grupos Santo Amaro e I Ihas) por sua praticabilidade, em termos de cartografia e paleogeologia. A unidade inicia-se com folhelhos silticos, areni. tos finos e argilosos, passando ao predominio de arenitos finos a mëdios, com estratificação cruzada e folhelhos esverdeados micäceos, perfazendo inümeras estruturas sedimentares primärias (escape de fluidos, escorregamento, diapirismo, corte e preenchimento, etc.).

O Grupo Massacarā (Kms), ou Formação São Sebastião, sobre põe transicionalmente as anteriores, com um perfil muito típico de arenitos finos avermelhados e estratificação cruzada, onde níveis grosseiros e conglomeräticos são intercalações comuns. A unidade é muito espessa (até $1000 \mathrm{~m}$ ) e mostra värias evidências de tecto nismo ativo durante a sedimentação.

A "Sequência do Petróleo" è o registro de uma sedimenta ção subaquätica, bordejada por leques aluviais. 0 preenchimento final do "rift" (lago) interior foi comandado pelos depósitos flu viatís da Formação São Sebastião, de acordo com GAMA JR., 1970 é NETTO, 1978.

A Formação Marizal (Kmz) é composta na base por conglomerados polimícticos cuja composiçäo reflete unidades sotopostas, e um perfil de arenitos quartzosos claros, estratificação cruzada, e mui ta variação lateral de fácies. Folhelhos e argilitos subsidiaria mente aparecem no perfil da unidade. A Formação Marizal exibe sem pre atitudes horizontais a subhorizontais, extrapola considerave 1 mente os limites dos "rifts" cretäcicos e recobre discordantemente terrenos paleozöicos e pré-cambrianos. Sua espessura é bastante va riảvel (atë $400 \mathrm{~m}$ ), de acordo com a superfície de discordância sub jacente, e devido a ação do ciclo erosivo atual. A desagregação 
física dos seus arenitos friäveis condiciona extensa cobertura elu vio-coluvionar (Qe1), mapeável em qualquer escala.

Sobrepostos à Formação Marizal hä remanescentes de aren $\underline{i}$ tos, folhelhos e calcários placosos, em Pernambuco (Ksa/Ke) e no norte da Bahia (Kst), reconhecidamente pouco estudados. Suas 1ito logias evocam aquelas presentes no Grupo Araripe, da chapada topô nima, e esta correlação à distância tem sido comum. Hä também sé melhanças estratigráficas, a serem melhor analisadas, coma parte superior da Formação Taipu-Mirim (Bacia de Camamu) e com as Forma ções Codó e Itapecuru (Bacia do Parnaíba).

\section{2 .2 - Bacia Sergipe-Alagoas}

\section{A) ASPECTOS GEOLOGICOS GERAIS}

A Bacia Sergipe-Alagoas tem uma expressão territorial emersa de $12000 \mathrm{~km}^{2}$, cerca de $2 / 5$ da sua extensão total, e cons titui uma faixa alongada $(300 \mathrm{~km})$, com muitas variações de largura, na direção nordeste, desde a falha de Itaporanga'd'Ajuda ao sul e - alto Maragogi-Barreiros, ao norte. Constitui a porção norte do dominio sedimentar Atlântico Central (MELO, 1982) da Província Cos teira ALMEIDA et al.,1977, cuja classificação moderna é de um tipo "rift" evoluindo para "pul1 apart", consoante PORTO e SzATMARI, 1982. Sua delimitação ao sul e ao norte, jä mencionados expressam feições positivas do embasamento, assim como a divisão intermediäria da bacia expressa no alto de Palmeira Alta-AL (Zona geoanti clinal de Propriā). Esta divisão primäria impõe decisivas diferen ças no contexto estrutural e estratigräfico da bacia e de toda sua evolução.

Nesta bacia, a coluna lito-estratigräfica reporta com fidelidade sem igual todos os estägios tectónicos e respectivas fa ses deposicionais que soem participar de um processo de deriva continental, em margem passiva. Alëm disso, estão bem resguarda dos depósitos intracratônicos anteriores a estes estágios, de antí gas bacias do continente Gondwana (Permo-Carbonífero).

A direção geral da bacia N45E é condicionada pelo mais importante sistema de falhas, no qual se situa a "falha de Propriä", da borda emersa. Outros sistemas dia onais (NS, E-W) e mesmo per 
pendiculares (NW) conferem à bacia uma complexa trama estrutural, resultando um mosaico de altos ("horsts"), baixos ("grabens e semi grabens") e degraus ("terraços"). E expressão geral que a bacia como um todo se comporta como monoclinal, com as unidades 1 ito-estra tigräficasmergulhando e se espessando para sudeste, mas esta $\overrightarrow{\mathrm{e}}$ uma conotação simplista. Este tectonismo tracional iniciou-se no Ju rässico Superior, com intermitência de intensidade, vindo a se atenuar só a partir do Cretäceo Superior-Terciārio Inferior, e quando a bacia adquiriu sua feição atual (de miogeoclíneo), con soante OJEDA e FUGITA, 1974.

O quadro estrutural ao sul de Palmeira Alta (Bacia de Ser gipe) é bem mais complexo, com altos e baixos se entrecortando diá gonalmente. Na parte alagoana (condizente com o embasamento grani tico) hā predominância do grande graben de Alagoas, de direção nor deste. Igualmente, enquanto a preservação de coluna 1ito-estratigräfica do Cretáceo Superior (Grupo Sergipe) é praticamente restri ta a Sergipe, em Alagoas estä presente todo o contexto subjacente ao Grupo Sergipe.

Sobrepõe-se a este esquema estrutural complexo a ativida de halocinética não perfurante, iniciada a partir do Cretāceo Supe rior, conduzida por algumas falhas de crescimento.

B) DESENVOLVIMENTO LITO-ESTRATIGRAFICO

a) Sedimentitos Gondwânicos

A Formação Batinga encerra diamictitos (Membro Mulungu) e ritmitos siltico-argilosos, em parte värvicos, relíquias das con dições glaciais do Carboniffero Superior (ROCHA-CAMPOS e BRITO NEVES, 1979). Provavelmente correlacionāvel com a Formação Curituba, da Bacia Tucano Norte.

A Formação Aracaré mostra intercalações de arenitos, fó Thelhos e calcários, estes associados a intensa e característica silicificação. Em contatos de topo e base mostram discordância paralela, e sua correlação e possível (esporomorfos) com a Forma ção Santa Brígida, da Bacia de Tucano Norte.

Estas relíquias da sedimentação do continente Gondwana tềm ärea de exposição limitadas às imediações de Igreja Nova no baixo curso do Rio São Francisco. 
b) Jurāssico Superior (Depressão Intradomos)

As Formações Bananeiras (folhelhos verdes e vermelhos) e Serraria (arenitos) mostram identidade litolögica e significação tectônica ("pré-rift") comuns ao do Grupo Brotas, como discutido em Tucano-Jatobá. Desta fase deposicional faz parte também a secção inferior - clástica fina da Formação Barra de Itiuba.

c) Cretáceo Inferior (Sequência dos Lagos)

os sedimentos da fase de "rift valley" nesta bacia estão reunidos sob a designação de Subgrupo Coruripe (SCHALLER, 1969), sen do muito variados, com clâsticos finos basais (Formação Barra de Itiuba), clâsticos médios com intercalação de folhelhos (Formação Penedo, Formação Coqueiro Seco) e calcários, com intercalações de arenitos, grauvacas e folhelhos (Formação Morro do Chaves).

As formações são por característica diagonais às linhas do tempo, com muitas interdigitações laterais, gradando todas para às bordas da bacia para cunhas de conglomerados polimícticos (For mação Rio Pitanga). De uma maneira geral hã uma repetição das con dições intracontinentais de deposição do Supergrupo Bahia, como discutido em Tucano-Jatobá.

d) Aptiano-Albiano (Sequência do golfo)

o perfil complexo e variado da Formação Muribeca, que é separada na capa e lapa por importantes discordâncias erosionais, é diagnóstico para esta fase deposicional mista.

Arenitos basais com intercalações de folhelhos e camadas evaporíticas (Membro Maceió), iniciou a sequência, passando a con glomerados polimícticos ciclöpicos (Membro Carmópolis), de grande expressão em afloramentos em Alagoas. O Membro Ibura, com anidri ta, halita, sais de potássio, folhelhos e calcários é capeado por uma espessa seç̧ão de folhelhos, arenitos e siltitos (Membro Oitei rinhos), com os quais se fecha esta fase deposicional com interve niência marinha.

e) Cretäceo Superior-Terciärio Inferior (Sequências do Mar)

o Grupo Sergipe é a designação utilizada para abranger os estratos marinho da Bacia Sergipe-Alagoas, dispostos segundo 
três ciclos transgressivo - regressivos mais ou menos completos, ain da que separados por discordâncias paralelas.

A Formação Riachuelo inclui arenitos e conglomerados (Membro Angicos), folhelhos e calcärios (Membro Taquari) nas par tes mais profundas. Os calcärios oolíticos e pisolíticos (Membro Maruím) e os dolomitos (Membro Aguilhada) são depósitos que corres pondem uma fase regressiva completando o ciclo albo-cenonaniano.

A Formação Cotinguiba (Turoniano-Santoniano) denuncia outro ciclo transgressivo que recobre o embasamento está composto por folhelhos e margas (Membro Aracajü), calcārios finos bem estra tificados (Sapucari) e calcärios brechados de talude (Laranjeiras).

A Formação Piaçabuçu (Campaniano-Eoceno) é composta por folhelhos calciferos (Calumbi), calcärios (Mosqueiro) e arenitos (Marituba) de ambientes de talude, plataforma e leques deltáicos respectivamente, consoante OJEDA e FUGITA, 1974. Esta distribui ção faciológica mostra migração dos depocentros para leste e carać teriza um ciclo regressivo geral.

f) Terciārio Superior-Quaternärio (Sequência VI ou Zeta)

o Grupo Barreiras recobre em discordância os sedimentos da bacia e o embasamento cristalino. Seu contexto subhorizontal de arenitos argilosos, arenitos conglomerados e conglomerados está muito comprometido em continuidade pelo ciclo erosivo atual. Ainda assim há inümeros reflexos dos falhamentos da bacia, e dos fenô menos cársticos do Grupo Sergipe estampados no Grupo Barreiras, que têm servido com frequência de veículos importantes dos estudos mor fo-estruturais.

\section{2 .3 - Bacia Potiguar ou Apodi}

A) ASPECTOS GEOLOGICOS GERAIS

A Bacia Potiguar ou Apodi se estende na zona costeira en tre Fortaleza e Natal, com ärea emersa na ordem de $22000 \mathrm{~km}^{2}$, in ferior a metade de sua extensão costa afora. Compreende a extremi. dade sul da província sedimentar desenvolvida com a formação do Atlântico Equatorial (MELO, 1982).

Esta bacia classificada como do tipo "rift" evoluindo para o tipo "pull apart" (PORTO e SZATMARI, 1982), devendo-se acres 
centar que se trata de um "rift" em parte paralelo à direção das falhas transformantes, mas outras observações deverão ser apostas a esta classificação.

No continente, a extensão reduzida em ärea, o contexto lito-estratigräfico incompleto presente, e a feição tabuliforme pre ponderante dos 1itossomas (em qualquer escala de anälise de super fície) por muito tempo constitiram sërios öbices à interpretação da evolução geológica desta bacia. Os estudos de subsuperficie da ültima década, no mar e no continente delinearam um quadro estrutú ral e estratigráfico complexos, destacando-se representação adequa da de todas as fases deposicionais de um processo de deriva contí. nenta1.

No continente, em primeira anälise, destacam-se três compartimentos tecto-estratigräficos. O graben central, configura do ao longo da mesopotâmia Açu-Apodi (delimitados por falhas NE, NNE) que é ladeado por dois extensos patamares monoclinais, com suave inclinação voltada para o lado do mar. A sequência do Cretă ceo Superior("G") - Formações Açu (parte) e Jandaira, recobrem de forma tabular toda a fração emersa, onclusive o graben central on de se restringem as sequências lito-estratigräficas mais antigas.

$\mathrm{Na}$ visão ao milionësimo cabe destacar certo controle es trutural imposto pela descontinuidades estruturais e geotectôni cas do embasamento. Os limites a oeste (Rio Chorō) e a leste da cobertura sedimentar cretäcica acham-se controladas por ações tar dias dos lineamentos de Senador Pompeu e Picui, o que é confirmado por estudos de subsuperfície (GOMES e MOTA, 1982). O graben cen tral da bacia se alinha de forma flagrante com zonas de falhas an tigas (Porta Alegre, Encanto) do embasamento, que são vistas la deando Uirauna e Pau dos Ferros. Na plataforma continental, os principais sistemas de falhas são paralelos à atual linha de costa.

\section{B) DESENVOLVIMENTO LITO-ESTRATIGRAFICO}

A Formação Pendência, de idade Prê-Aptiano, restrita à subsuperficie, compreende folhelhos, siltitos e arenitos intercala dos, terrígenos sintectônicos da fase "rift" sobrepostos discór dantemente ao embasamento. Suas espessuras máximas são estimadas na ordem de $3500 \mathrm{~m}$ (SOUZA, 1982), nas calhas mais profundas do 
graben central, estruturado diagonal à linha de costa.

$$
\text { Formação Alagamar (não aflorante e predominantemente }
$$
da zona submersa), com intercalações de clästicos e carbonaticos, de idade aptiana representa a fase transicional (proto-oceânica), com os primeiros registros de influência marinha na bacia.

A Formação Açu, de idade albiana-turoniana, apresenta uma secção inferior de clästicos grosseiros, arenitos e conglomerados dominantes, de ambientes fluviais (F). A secção superior é compos ta de arenitos finos, siltitos e argilas, como registro de fäcies deltäicas, lagunares e litorâneas (G). As maiores espessuras co nhecidas $\mathrm{s}$ ão da ordem de $700 \mathrm{~m}$, na parte jusante do graben central. Para o lado do mar, esta unidade grada sequências sedimentares ma rinhas (Formaçöes Ponta do Mel e Ubarana).

A Formação Jandaira, de idade turoniana-campaniana, é es sencialmente composta por carbonatos marinhos de värios tipos, de $\underline{s}$ tacando-se calcarenitos. Intercalações de calcärios margosos e calcários dolomíticos são comuns na secção superior da unidade. A oeste de Macau são conhecidas as maiores espessuras, na ordem de $650 \mathrm{~m}$.

Rochas bäsicas olivínicas ( $\mathrm{Tdb}$ ) cortam a sequência cretạ cia e afloram em värios pontos ao sul de Macau (Formação Macau). Sedimentos variegados continentais do Grupo Barreiras e depósitos costeiros (praias, dunas) completam e ajustam a paisagem dominan te de tabuleiros desta bacia costeira.

Para a plataforma continental, as unidades descritas gra dam para unidades distintas, e o perfil estratigräfico pös-Jan daira cresce consideravelmente com a representação completa de um ciclo regressivo-erosional (Formações Ubarana, Guamarë e Tibau), da parte mais superior do Cretäceo ao Terciärio Superior. 
0 ajuste do "graben" central da Bacia Potiguar com zo nas falhadas do embasamento têm informações complementares e in teressantes. A presença de restos sedimentares mesozóicos do Rio Nazare e do Rio do Peixe pode representar vestígios de uma exten são pregressa da bacia para o interior remoto do continente.

Por outro lado, $\vec{e}$ interessante a composição do sistema de falhas do continente, NNE, com aqueles da plataforma continen tal (paralelos a linha de costa) de direção NW e E-NE. Trata-se de um esquema sugestivo de uma junção tríplice, da qual o "graben" central (NNE) viria constituir o ramo abortado (aulacögeno) e os dois outros ramos propiciaram a evolução da margem continental atual.

\section{2 .4 - Bacias do Saliente Oriental}

A faixa sedimentar costeira do chamado Saliente orien tal do Nordeste, considerada entre os altos de Touros e Maragogi-Barreiros, se dispõe francamente diagonal às estruturas do emba samento, e soma uma extensão da ordem de $12000 \mathrm{~km}^{2}$.

Um tratamento em separado deste segmento da Província Costeira começou a ser instituído por BEURLEN, 1967, que the atri buiu ação de retardatärio, no processo de formação do Atlântico. Tal tratamento/classificação. baseado no reduzido conteủdo 1ito-estratigráfico, e pela posição intermediāria a duas bacias de de senvolvimento distintos entre si (Sergipe-Alagoas e Potiguar), per sistiu em diversos trabalhos, entre os quais se destacam os de ASMUS e CARVALHO, 1978 e MELO, 1982, aindaque com argumentos dife rentes daqueles de BEURLEN, 1967.

A coluna estratigräfica incompleta e outras peculiaridades desta bacia, na sua parte emersa, têm sido atribuídas a uma posição e atuação tectônicas peculiares (em qualquer das hipóte ses formuladas) no decurso da deriva continental.

E possível distinguir três diferentes domínios ou "sub-bacias" nesta fração da Província Costeira, delimitados en aci dentes estruturais do embasamento, e reativados no Cretäceo, com repercussão direta na evolução lito-estratigräfica. Esta obser 
vação está acima inclusive da falta de informações (ou das infor mações incompletas) de subsuperfície, haja vista que o nível geral de conhecimento desta bacia é insatisfatório.

A) A sub-bacia norte é considerada entre o alto de Touros (RN) e a falha (vale) de Mamanguape (PB). Trata-se de uma ārea extensivamente capeada pelo Grupo Barreiras (TQb), depósitos are nosos (TQC), aluviões e sedimentos de praia (em parte), de forma que seu conhecimento lito-estratigräfico é escasso. Há ocorrências isoladas de calcärios em vales e poços tubulares, e de unidades areniticas infra-Barreiras, todos insuficientemente descritos e/ou correlacionados. Intensa segmentação de blocos ë observāvel nesta bacia, consoante falhas policíclicas ENE (Camaratuba,Curimatau, Jacú, etc.) do embasamento que retificam praticamente todos os va les e influem no contexto morfo-estrutiral das värias coberturas.

B) A "sub-bacia" central, ou Recife-João Pessoa, é cons i derada entre a falha de Mamamguape (PB) e o lineamento Pernambuco, em Recife (PE). Apresenta um pacote da ordem de $400 \mathrm{~m}$ (porção emer sa) de sedimentos cretácicos e eo-terciärios, que mergulham suave mente (4 a $20 \mathrm{~m} / \mathrm{km})$ para o 1 ado do mar, tendo borda ocidental nit $\underline{i}$ damente erosiva.

A sequência sedimentar presente pode ser dividida em duas partes (AMARAL et a1., 1977), conhecidas como Grupo Paraíba.

a) Clástica basal, de carāter terrígeno, reunindo os se dimentos das Formaçöes Beberibe e Itamaracá (subsuperfície), limi tada no topo por um horizonte de fosforito. A Formação Beberibe $\vec{e}$ composta por arenitos friāveis, argilosos, mal selecionados, não fossilifferos $( \pm 200 \mathrm{~m})$, de provävel origem continental e transicio nal. A Formação Itamaracá é constituída de arenitos calcíferos, do lomiticos, mẻdios a grosseiros, com intercalações dolomíticas, de origem litorânea, com mäximo de $280 \mathrm{~m}$. Esta unidade de transgres são ë datada de Santoniano-Campaniano ao início do Maestrichtiano.

b) Carbonätica suverior, reunindo os biomicritos argilo sos, margas e argilas da Formação Gramame (inclui nível de fosfori to basal) que representam depósitos marinhos rasos (espessura máxi. ma de $40 \mathrm{~m}$ ), e os sedimentos calciclästicos (em torno de $35 \mathrm{~m}$ ) da Formação Maria Farinha, representativos da regressão deste ciclo, 
no início do Terciārio.

o Grupo Barreiras recobre os sedimentos deste ciclo, cons tituindo empecilho constante à obtenção de secções completas em superfície. A presença/ausência deste capeamento reflete muitas vezes deslocamento tectónico de blocos da bacia. Hâ possibilidade da ocorrência de unidades lito-estratigräficas infra-Santoniano, no continente e na plataforma continental, cuja identificação (pro posta por gravimetria) imprescinde de poços pioneiros.

C) A sub-bacia "Su1 do Recife" estä situada ao sul do $1 \underline{\text { i }}$ neamento Pernambuco, entre este e o alto "Maragogi-Barreiros". Seu limite oeste é constituído por um cordão de falhas NS-NNE, cretäci cas, acompanhadas de conglomerados polimicticos e arcóseos, sintec tônicos da Formação Cabo.

Outro fator distintivo, alëm da marcante segmentação por falhas e as espessuras conhecidas (milhares de metros) do pacote sedimentar, é a presença de um complexo vulcânico e subvulcânico composto de basaltos, andesitos, riolitos, traquitos, dioritos, etc., da Formação Ipojuca, proposta por AMARAL e MENOR, 1979, cujas ida des K/Ar estão em torno de 90-100 m.a. E, ainda, do riebeckita granito do Cabo Santo Agostinho.

Algumas ocorrências descontínuas de calcārios maciços com intercalações argilosas, por toda costa sul de Pernambuco (não cartografāveis na escala do mapa) tem sido incluído na Formação Es tivas, de provāvel idade albo-cenomaniana, em sobreposição à Forma ção Cabo.

0 início de perfurações profundas da Petrobräs nesta sub-bacia (em 1982) abre novas perspectivas para esclarecimento da sua coluna lito-estratigräfica, presentemente inconclusa. 
12 - A COBERTURA DA "PROVINCIA BORBOREMA" (s.s.)

\section{1 - REMANESCENTES SEDIMENTARES PALEO-MESOZOICOS DO INTERIOR DO NORDESTE}

A designação de bacias sedimentares aos remanescentes en fatizados no Quadro 12.1, corresponde mais a um vício de linguagem, eivado de um simplismo comprometedor.

Como pode ser visto no mapa geológico e nos Quadros 10.1 e 12.1 três aspectos são essenciais:

a) A delimitação no espaço geogrä́fico-geológico depende de reativações de falhas do embasamento.

b) Apresentam sempre uma sequência lito-estratigräfica descontínua, onde as defecções prevalecem.

c) Mesmo abordadas em conjunto, fica dificil reconsti tuir os eixos e histórias deposicionais.

$\mathrm{Na}$ verdade estas "bacias" são frações de uma cobertura mais extensa, de mais de um ciclo tecto-sedimentar, circunstancial. mente retidas em falhas reativadas (a maioria) e criadas na reati vação juro-cretäcica. Naturalmente, algumas margens destas baciras são verdadeiras, posto que são acompanhadas por conglomerados sin tectônicos. Mas, em grande maioria, seus bordos retilíneos são processos combinados de erosão e afundamento lento.

A comparação de suas colunas lito-estratigräficas com as das Bacias do Parnaíba, Tucano-Jatobá e Potiguar, é um exercício atraente, mas nem sempre de êxito. Em todas elas, a coluna lito-estratigráfica não dispõe (quase que absolutamente) de dados de subsuperfície e de um estudo sistemático (1ito e bio-estratigräfi co) aprofundado das unidades expostas em superfície.

A presença da sequência do Paleozóico Inferior é discutí vel nos fragmentos do Rio do Peixe e do Médio Jaguaribe. A liga ção das Formações Brejo Santo e Missão Velha com o Grupo Brotas é fruto de estudos de reconhecimento (BRAUN, 1966). A presença de "rifts" (Sequência dos Lagos) no Araripe, recoberto pelos litos somas tubulares apto-albianos é provāvel, e insinuado na análise 
de alguns perfïs gravimétricos (H. RAND, informação inëdita). Uma antiga conexão entre os arenitos Exu (Araripe) e Açu (Bacia Potí guar) tem respaldo palinológico, consoante LIMA, 1978. Por outro lado, os sedimentos de Encanto/Rio Nazaré e do Rio do Peixe podem ser restos da extensão para o sul da Bacia Potiguar. Em suma, hä muitas questões em aberto, temas interessantes de pesquisa estrati. gräfica e paleogeogräfica.

No Quadro 12.1, a coluna da Bacia de Tucano é colocada para termos de comparação, por reunir maior nümero de unidades equivalentes com as destas "bacias". Mas, a possibilidade de cone xões com a Bacia do Parnaíba e a Bacia Potiguar (ou com todas elas) deve tambēm ser esquadrinhada em futuro, e posta em evidência des de $j \vec{a}$.

\section{2 - DEPOSITOS CENOZOICOS}

Os depósitos cenozóicos foram enfatizados por quase to dos os autores, que discutiram a sequêncição sedimentar do craton como resposta a um estägio tectônico peculiar, ortoplataformal.

As principais āreas de ocorrência destes depösitos se 1o calizam acobertando a Província Costeira e/ou nos baixos cursos dos grandes rios regionais. As ocorrências do interior, via de regra, estão em pleno processo de desmantelamento pelo ciclo erosivo atual ("Paraguaçu"), restando 1 itossomas tênues e descontínuos, muitas ve zes negligenciados at $\vec{e}$ pelos mapeamentos geológicos de pequena es cala. Estes depósitos se referem a fases tectônicas e deposició nais importantes, que podem contribuir para o conhecimento da his tória policíclica de pediplanização do Nordeste.

A nível local e regional, o conhecimento é perfuntório, preexistindo algumas sinteses (MABESOONE et a1., 1972; MABESOONE e CAMPANHA, 1974) em parte välidas, em parte fundamentada em certo empirismo de regionalização geomorfológicas muito extensas. A ex tensão em ārea de cada unidade, os limites laterais e cronológicos entre elas, o estudo sedimentológico objetivo de seus Iitossomas, etc. ainda são fases do conhecimento a serem preenchidas. Interpre tações paleoclimāticas e tectônicas em cima dos dados atuais são precārias, apesar de rotineiras. 


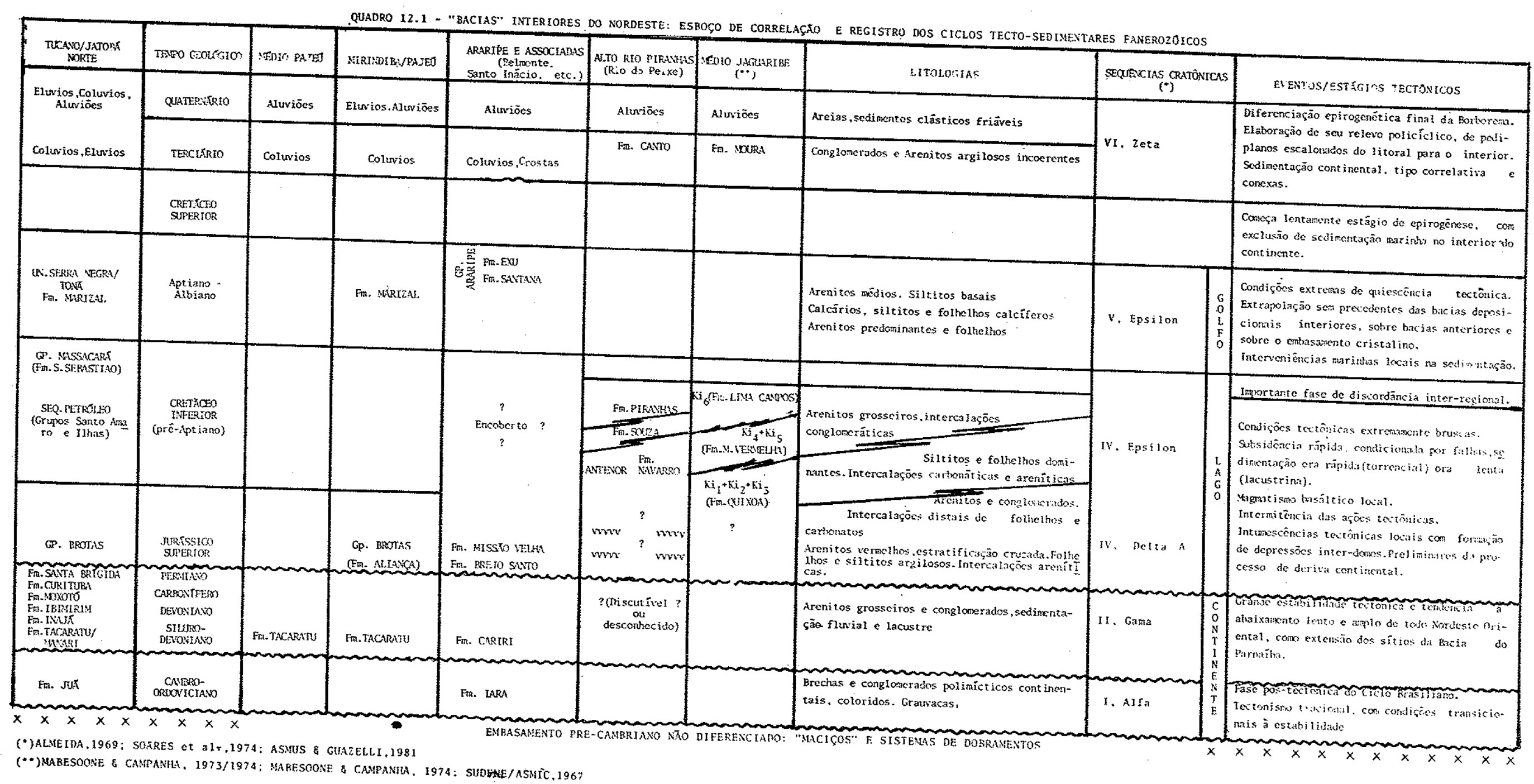


Ao lado da importância cientifica de analisar as fases de aplainamento (estabilidade) e sedimentação (rutura do equilíbrio), värios bens minerais são conhecidos nestes depösitos, a saber: areias, areias ilmenitíticas, argilas, diatomitos, turfas, calcârios, etc.

No propósito de sintese ê possível distinguir três fases (ou conjunto de fases) deposicionais, tendo por referência o len çol terrígeno principal do Grupo Barreiras, que tem a maior expres são territorial, e provảvel idade pliocênica, ou plio-pleistocênica (imprecisão e diferença de capa e lapa esperäveis, de um local para outro).

a) Depósitos "infra-Barreiras"

Os principais depösitos terciärios infra-Barreiras estão ligados a fase final de evolução das bacias costeiras - Formações Tibau, Maria Farinha, Pذ̇açabuçu, etc. - tendo por capa uma super fície de discordância erosiva e angular.

Uma unidade de arenitos quartzosos, com níveis conglome rāticos tem sido identificado em subsuperfície ná costa do Rio Grande do Norte (Formação Tibau ?), sotoposta discordantemente às tipologias clässicas e variegadas do Grupo Barreiras.

Na pröpria Bacia Potiguar, discordante sobre a Formação Jandaira, e coroando värias chapadas do interior do Rio Grande do Norte e da Paraíba (Tsm, TQb, TQu em parte) se encontram restos de depósitos continentais areno-argilosos que completam frações da an tiga Superfície Sulamericana. Estes depósitos tem recebido dive $\underline{r}$ sos nomes locàis, Cerro Corä, Araruna, Solânea, Teixeira, Serra do Martins (TQm), Cuité, Teixeira, "Paleovale", etc. de acordo com a serra/resíduo de preservação.

$\mathrm{Na}$ faixa costeira, sob o "Barreiros" típico, hả vārias referências à depósitos ligados a esta fase, que estariam pois so brepostos a uma superfície geomorfológica com cotas decrescentes do interior para o litoral, e datada de Terciärio Inferior.

Outro grupo de depósitos desta época preenchem paleo-de pressões, constando de arenitos conglomeráticos basais, argilas do minantes no perfil (argilas bentoníticas da Paraíba e Rio Grande do Norte), com intercalações areníticas. A preservação destes de pósitos se deu graças à coberturas basālticas, como aquelas de Boa 
Vista (sudoeste de Campina Grande)e norte de Soledade (Cubati).

b) "Barreiras" e Cronocorrelatos

As rochas do Grupo Barreiras têm constituição litológica e organização estrutural interna variāvel de ponto a ponto, em fun ção de variação das condições de fonte, tectônica e clima. Predomi nam areias argilosas variegadas, com inserção de 1inhas, lentes, níveis e camadas de seixos, e baixo grau de consolidação em geral. Truncamento de leitos e camadas, diastemas, são frequentes.

De uma maneira geral apresenta superfície basal inclina da do litoral para o interior, cortando rochas pré-cambrianas e de pösitos sedimentares preexistentes. Uma formação por cones alu viais coalescentes, corridas de lama e areia, etc. tem sido aponta da de um local para outro.

Algumas fäcies se caracterizam pela abundância das linhas de seixos (como em Sergipe), havendo locais com franco predomínio de litossomas conglomeráticos (Formação Moura, TQm; Formação Canto, Formação Faceira, TQf, etc.). A chamada Formaçãơ Capim Grosso (TQcq) se caractexiza por um nível basal conglomerätico, dominante em algu mas exposições, que preenche paleovales, e por um manto arenoso ou areno-argiloso de baixíssimo grau de consolidação.

A Formação Caatinga (TQcaat) ê considerada como correlata geomorfológica (Superfície Velhas) e cronológica dos demais grupos terrígenos e continentais. Sua distribuição é ao longo dos vales dos rios afluente do Mëdio São Francisco, sendo constituída de cal cärios, calcärios fragmentärios, nïveis de brechas calcíferas. Lo calmente, identifica-se niveis basais conglomeräticos, e variações laterais para fäcies arenosas.

E possível que parte dos depósitos de talude (Chapada do Araripe, Serra do Teixeira, etc.), depósitos coluviais (Bacia de Ja tobâ) e mesmo aluviões (terraços, frações subsuperficiais), em maior parte não cartografadas, possam ter participado desta ampla e diver sificada época de pediplanização regional.

c) Depösitos "Pös-Barreiras"

o grupo mais importante a destacar (extensão territorial) 
são os depósitos arenosos pouco ou não consolidados que sobrepõe a unidade Barreiras e o embasamento cristalino (TQC). As "areias brancas" da faixa costeira nordestina, os depósitos de lagos e ala gados interiores, etc.

Os eluviões ganham grande expressão na Bacia de Jatobâ, e estão ainda em franca fase de formação, devido as drästicas con dições climáticas e a natureza arenosa do substrato.

As dunas são importantes no Médio São Francisco, cobrin do por milhares de quilômetros quadrados depósitos terciários. Mais restritamente aparecem na faixa costeira.

Os aluviões (Qa) e sedimentos de praia ( $Q p$ ) são importan tes no leito dos grandes rios e na faixa litorânea. Seu conhecí mento em subsuperfície é muito precário ainda, apesar da importân cia econômica de que tem se mostrado. 


\section{BI BLIOGRAF IA}

ABREU,F.M.de; VILLAS,R.N.N. \& HASUI,Y. - 1980 - Esboço estratigräfico do Pré-cambriano da região de Gurupi, Estados do Pará e Maranhão - XXXI Cong.Bras.Geol., Camboriú, 1980. Anais, vol. $\underline{2}$, pp. 647-658.

AGRAWAL,V.N. - 1981 - Preliminary note on the deformation in the mylonite zone of the Serra das Russas,PE - X Simp.Geo1.Nord., Re cife, 1981. Atas, pp.361-364.

AGUIAR,G.A. - 1971 - Revisão Geológica da Bacia Páleozóica do Maranhão - XXV Cong.Bras.Geo1., São Paulo, 1971. Anais, vo1.포.pp. 113-122.

ALBUQUeRque,J.P.T. - 1970 - Inventārio Hidrogeológico do Nordeste: Folha 15, Jaguaribe SE. Recife, HG/SUDENE, Sërie Hidrogeologia, 32, p. 187 .

ALBUQUERQUE,J.P.T. - 1977 - Mapa Geológieo da Bacia do Capibaribe 1/100.000. Recife, Acquaplan/Condepe/Eletroconsult, (circulação restrita).

ALBUQUERQUE, J.P.T. \& BRITO NEVES,B.B. - 1978 - Inventärio Hidrogeo lógico do Nordeste: Folha 21, Recife,NO - Recife,Brasil/SUDENE, Série Hidrogeologia, 54, $184 \mathrm{pp}$.

ALBUQUERQUE,J.P.T. E FERREIRA,J.A.M. - 1979 - Mapa Geológico do Etado da Paraíba, escala 1/250.000 - Campina Grande, CINEP/ATECEL (circulação restrita).

ALMEIDA,A.C.F.de - 1967 - Geologia das Bacias de Jatobä e Tucano Norte - Rio de Janeiro, CENPES/PETROBRÁS, Coletânea de Relatörios de Exploração I, pp.145-155.

ALMEIDA,F.F.M.de - 1965 - Precambrian geology of Northeastern-eastern Brazil and Western Africa and the theory of continental drift

- Rev.Natural Resources Research, $\underline{8}(4): 151-162$.

ALMEIDA,F.F.M.de - 1969 - Diferenciação tectônica da plataforma bra sileira - XXIII Cong.Bras.Geo1., Salvador, 1969. Anais, pp.29-46. ALMEIDA,F.F.M.de - 1977 - O craton de São Francisco - Rev.Bras.Geoc., 7(4): 349-364, São Paulo. 
ALMEIDA,F.F.M.de; HASUI, Y. \& BRITO NEVES,B.B.de - 1976 - The upper precambrian of South America - Bol.IG, 7 $: 45-80$, São Paulo. ALMEIDA,F.F.M.de; HASUI,Y.; BRITO NEVES,B. B.de \& FUCK,R.A.- 1977 Provincias Estruturais Brasileiras - VIII Simp.Geol.do Nordeste da SBG, Campina Grande, PB, 1977. Atas, pp.363-391.

ALMEIDA,F.F.M.de; HASUI, Y.; BRITO NEVES, B.B.de \& FUCK,R.A. - 1981 Brazilian Structural Provinces: an introduction - Special Issue Earth Sc. Rev., 17(1/2):1-30, Amsterdam.

ALMEIDA,F.F.M.de; VALENÇA,J. \& LEONARDOS JUNIOR,O.H. - 1968 - Granitic rocks of northeast south America - In: Simpösio sobre rochas graníticas - Recife, Int.Union of Geol.Sci./UnESCO. Publ. Esp., $41 \mathrm{pp}$.

AMARAL,A.J.R.do \& MENOR,E.de A. - 1979 - A sequência vulcano-sedimentar cretåcica da Região de Suape(PE): Interpretação faciológica e considerações metalogenëticas - IX Simp.Geol.do Nordeste da SBG, Nata1, 1979. Atas, pp.251-271.

AMARAL,A.J.R.do; MENOR,E.de A. ¿ SANTOS,S.A. - 1977 - Evolução paleogeogräfica da sequência clástica basal da bacia sedimentar costeira Pernambuco-Paraíba - VIII Simp.Geol.do Nordeste da SBG, Campina Grande, PB, 1977. Atas, pp.37-63

ANDRITZKY,G. - 1972 - Geologia e ocorrências de scheelita na ärea de Santa Luzia (Estados de Paraíba e Rio Grande do Norte) - Han nover, SUDENE/Bundesanstalt für Bodenforschung, 2 vol.il. ANDRITZKY,G. et a1. - 1974 - Mapa geolögico da região de Santa Lu zia 1/100.000 - Hannover/Recife, Missão Geolögica Alemã/Divisão de Geologia da Sudene.

ANGEIRAS,A.G.; NETTO,A.M. \& CAMPOS,M - - 1978 - Mineralizações fösforo-uraniferas associadas a episienitos södicos no pré-cambria no Cearense - XXX Cong.Bras.Geol., Recife,1978 - Resumos das có municações. Bo1.01, p.341.

ANHAEUSSER,C.R. - 1975 - Precambrian tectonic environments - Annual Review of Earth and Plan.Sci.Letters, 3: 31-52, Palo Alto 
ANHAEUSSER,C.R.; MASON,R.; VILJOEN,M.J • \& VILJOEN,R.P. - 1969

A reappraisal of some aspects of Precambrian Shield Geology Geo1.Soc.Am.Bu11. 80 (11): 2175-2200, Boulder.

ASMUS,H.E. - 1975 - Controle estrutural da deposição mesozóica nas bacias da margem continental brasileira - Rev.Bras.Geoc. 5 (3): 160-175, São Paulo.

ASMUS,H.E. \& CARVALHO,J.C. - 1978 - Condicionamento tectônico da sedimentação nas bacias marginais do Nordeste brasileiro (Sergi pe-Alagoas e Pernambuco-Paraíba): Contribuição ao Projeto Brasi leiro de Geodinâmica (Projeto REMAC) - Rio de Janeiro, Mimeogr). Projeto REMAC (prë-print) $23 \mathrm{pp}$.

ASMUS,H.E. \& GUAZELLI,W. - 1981 - Descrição sumária das estruturas da Margem Continental Brasileira e de āreas oceânicas e continen tais adjacentes. Hipótese sobre o tectonismo causador e implica ções para os prognösticos do potencial de recursos minerais.Rio de Janeiro, CENPES/PETROBRÁS, Série Projeto REMAC,9,pp.187-269. AUBOUIN,J. - 1965 - Geosynclines - Development in Geotectonics, 1 Amsterdan - E1sevier Pub1. Co., 335 pp.

AUSTRAL/CARAIBA METAIS S.A. - 1981 - Projeto Cearä: Relatório final - Salvador, $110 \mathrm{pp}$. (inédito).

BALLY,A.W. - 1980 - Basins and subsidence. In: "Dynamics of plate interiors" - Am.Geoph.Union, Geodynamics Series, vol.1.pp.5-20. BALLY,A.W. \& SNELSON,S. - 1980 - Rea1ms of Subsidence. In: "Facts and Principles of World Petroleum Ocurrence" - Can.Soc. Petrol. Geo1.Memoir 6: pp.9-75.

BARBOSA,A.J. et al. - 1977 - Projeto Crateús: relatório final- Re cife, DNPM/CPRM, 7 volumes (circulação restrita).

BARBOSA,A.J.; BRAGA,A.P.G.; BEZERRA,M.A. \& GOMES,J.A.V. - 1974-Pro jeto leste do Paraíba e do Rio Grande do Norte - Recife, DNPM/ CPRM. 4 volumes (circulação restrita).

BARBOSA,0. - 1965 - Geologia das folhas de Remanso e Sento Së, Esta do da Bahia - Rio de Janeiro, PROSPEC/DNPM, 15 pp.

BARBOSA,0. - 1970 - Geologia Econômica de parte da região mëdio São Francisco - Bo1.DNPM/DFPM, (140): pp.1-98, Rio de Janeiro. (Rela tório inédito - Projeto Cobre - 1964). 
BARD,J.P.; BURG,J.P.; MATTE,Ph. . E RIBEIRO,A. - 1980 - La chaine her cynienne d'Europe occidentale en termes de tectonique des plaques - In: Colloque C-6: geologie de L'Europe,from précambrien aux bassins sedimentaires post-hercyniens - XXVI Cong.Geol. Inter nac., Paris, 1980 - pp. 233-246.

BARRETO,A. - 1967 - Mapa geológico do município de Independência,CE - Recife, DGM/SUDENE, (inëdito).

BARRETO,A. - 1967 - Sumário geolögico da região rutilífera de Independência,CE - Estudos da Divisão de Geologia; SUDENE, (2) :pp.3947. Recife.

BARRETO,P.M.C. - 1968 - o paleozóico da bacia de Jatobá, Pernambuco - Bol.da Soc.Bras.Geol., 17 (1):19-46, São Paulo.

BARROS,F.A.R.; DOVALE,P.A.R. G LETTE,E.A. - 1978 - Projeto integração geológica-geofísica Cariris Velhos, relatörio final - Recife, DNPM/CPRM, 1 volume (circulação restrita).

BERTRAND,J.M.L. \& CABY,R. - 1978 - Geodynamic evolution of the Pan

Africa orogenic belt: a new interpretation of the Hoggar Shield

(Algerian Sahara) - Geol.Rundsch. 67(2):357-388, Sttutgart. BEURLEN,K. - 1967 - A estrutura geológica do nordeste do Brasil

XXI Cong.Bras.Geo1., Curitiba, 1967. Anais, pp.151-158.

BEURLEN, K. - 1971 - Bacias sedimentares no bloco brasileiro - Estud.

Sedim. $1(2): 7-31$, Recife.

BEURLEN, K.; SIAL,A.N. \& BRITO NEVES, B.B.de - 1978 - Considerações

sobre a geologia da ärea entre Piancō e Catingueira, PB -XXX Cong.

Bras.Geo1., Recife, 1978. Anais, vol.1, pp.58-68.

BIRD,J.M. \& ISACKS,B.,ed. - 1972 - Plate Tectonics - Selected papers

from the Journ.of Geoph.Research, Washington, Am. Geoph. Union, $563 \mathrm{pp}$.

BODENLOS,A.J. - 1950 - Magnesite deposits of central Cearä, Brazi1Washington, Government Printing office, 153 pp.il.

BRAGA,A.P.G. et alii - 1977 - Projeto Fortaleza, relatório final Recife, DNPM/CPRM, 10 volumes (circulação restrita). BRAUN,O.P.G. - 1966 - Estratigrafia de sedimentos da parte interior da região nordeste do Brasil - Rio de Janeiro, DNPM/DGM, Bo1.236, $73 \mathrm{pp}$.

BRAUN,O.P.G. - 1969 - Geologia da bacia do Rio do Peixe, Nordeste do Brasil - Rio de Janeiro,PROSPEC/DNPM(Relatório inëdito), 23 pp. 
BRITO NEVES,B.B.de - 1973 - Elementos da geologia precambriana do nordeste oriental - XXVII Cong.Bras.Geol., Aracajü, 1973. Anais, vo1. 3 , pp.105-134.

BRITO NEVES,B.B.de - 1975 - Regionalização geotectônica do Precambriano nordestino - São Paulo, $198 \mathrm{pp}$. (Tese de Doutoramento apresentada ao Instituto de Geociências da Universidade de São Paulo), circulação restrita.

BRITO NEVES,B.B.de - 1978 - A propōsito da evolução 1ito-estratigrâa fica do Precambriano Superior do Nordeste - Jorn.Minera1., $\underline{7}$ : 19-27, Recife.

BRITO NEVES,B.B.de - 1979 - Considerações sobre determinações geocronológicas $\mathrm{Rb}-\mathrm{Sr}$ e K-Ar na zona norte do Craton de São Francis co - Salvador, CPRM, 13 pp. (inëdito).

BRITO NEVES,B.B.de - 1980 - Súmula da geocronologia de Pernambuco -

In: Mapa Geológico do Estado de Pernambuco, texto explicativo. Re cife, DNPM, Mapas e Cartas de síntese, 1. Secção Geologia 1, pp. 54-66.

BRITO NEVES,B.B.de - 1981 - O Ciclo Brasiliano no Nordeste - X Simp. Geo1.do Nordeste da SBG, Recife, 1981. Atas, pp.329-337. BRITO NEVES,B.B.de - 1982 - Evolução Geocronológica do Prë-cambriano de Alagoas - avaliação primeira - Maceiō, EDRN-AL, 20 pp. (inê dito). Relatörio Tec.apresentado à EDRN-AL.

BRITO NEVES, B.B.de - 1982 - Síntese da geocronologia. In: Mapa Geoló gico do Estado da Paraíba, escala 1/500.000: texto explicativo Campina Grande, PB, CDRM/PB, pp.53-69.

BRITO NEVES,B.B.de et a1.: - 1978 - Estudo da geocronologia da faixa costeira precambriana do Nordeste - Relatório de pesquisa - Re cife/São Paulo, UFPE/CNPq/CPGeoUSP, 25 pp.

BRITO NEVES,B.B.de et al. - 1982 - Geologia das folhas Salgueiro e Cabrobó 1/100.000 - Recife, DNPM/UFPE, 30 pp. Relatório Tecnico apresentado, Conv.DNPM/UFPE (inédito).

BRITO NEVES,B.B.de \& ALBUQUERQUE,J.P.T. - 1971 - Geologia do A1to

Paraíba: folhas Prata, Sumë, Coxixola e Poções, 1/100.000-Recife, HG/SUDENE, (inédito).

BRITO NEVES, B.B.de \& ALBUQUERQUE, J.P.T. - 1978 - Inventärio Hidrogeo 1ógico bäsico do Nordeste. Folha 16, Paraíba so-Recife, Brasil/ SUDENE, Série Hidrogeologia, 53, 167 pp. 
BRITO NEVES, B.B.de; ANJOS,N.F.R.dos \& SOUTO MAIOR, J. - 1970 - Mapa Hidrogeológico do Nordeste - Folha 25, Aracajú SE - Recife, SUDENE/Div.Hidrog.

BRITO NEVES, B.B.de \& CORDANI,U.G. - 1973 - Problemas geocronolögicos do geossinclinal Sergipano e do seu embasamento - XXVII Cong. Bras.Geol., Aracajú, 1973. Anais, vo1.2, pp.67-76.

BRITO NEVES, B.B.de; CORDANI,U.G. \& TORQUATO,J.R.F. - 1980 - Evolução Geocronológica do Prë-cambriano do Estado da Bahia - Geol.e Rec.Min.do Estado da Bahia, textos bäsicos, 3: 1-101, Salvador. BRITO NEVES,B.B.de; KAWASHITA,K. \& MELLO,E.Z.U.de - 1977 - Estudo Geocronolögico do. Grupo Estância pelo mëtodo Rb-Sr - VIII Simp. Geol.do Nordeste da SBG, Campina Grande-PB, 1977. Atas, pp. 311-321.

BRITO NEVES, B.B. de; KAWASHITA, K. \& PESSOA,D.A.R. - 1975 - A posição estratigräfica do Complexo Caicó - VII Simp.Geol.do Nordeste da SBG, Fortaleza., 1975. Atas, pp. 289-297.

BRITO NEVES, B. B. de \& PESSOA,R.J.R. - 1974 - Considerações sobre as rochas graníticas do nordeste orienta1 - XXVIII Cong.Bras.Geo1., 1974. Anais, pp.143-157.

BRITO NEVES, B.B.de; STAL,A.N. \& ALBUQUERQUE,J.P.T. - 1977 - Vergência centrifuga residual no sistema de dobramentos Sergipano Rev.Bras.Geoc., 7 (2):102-114, São Paulo.

BRITO NEVES, B.B. de; SIAL,A.N. \& BEURLEN,H. - 1978 - o sistema de do bramentos Sergipano - análise do conhecimento. Reunião preparatö ria para o Simpósio sobre o Craton de São Francisco e suas faixas marginais - Salvador, SBG/SME-BA/CPM. Pub1.Esp.SBG $\underline{3}, p p .369-$ 391 e 392-398.

BRITO NEVES, B.B.de; SIAL,A.N.; RAND,H.M. \& MANSO,V.V. - 1982 - The

Pernambuco-Alagoas Massif, Northeast Brazil - Rev.Bras.Geoc. $\underline{12}$ (1/2/3):240-250, São Paulo.

BRITO NEVES, B.B. de; VANDOROS,P.; PESSOA,D.A.R. \& CORDANI,U.G.-1974Reavaliação dos dados geocronológicos do Nordeste Brasileiro XXVIII Cong.Bras.Geo1., Porto Alegre, 1974. Anais, vol. 6 ,pp. 261-
272 .

BUDDINGTON,A.F. - 1959 - Granite emplacement with special reference to North America - Bul1.Geol.Soc.Am. 70 (6):671-747. 
BUKHARIN,A.K. \& PYATKOV,K.K. - 1973 - Eugeosynclinal, miogeosyncli nal and transitional structures (as ilustrated in Uzbekistan) Geotectonics, 1973(2): 86-89, Washington.

CABY,R.; BERTRAND,J.M.L. \& BLACK,R. - 1981 - Pan-African Ocean Closure and continental collision in the Hoggar-Iforas segments, cen tral Sahara. In: Precambrian plate tectonics by A.Kröner. Amster dan, Elsevier Publ.Co., pp.407-434.

CALDASSO,A.L. - 1967a - Geologia da quadricula E-093, folha Crato. Recife, SUDENE, Série Geologia Regional, 4, $39 \mathrm{pp}$.

CALDASSO,A.L. - 1967 b - Geologia da quadrícula E-94, folha Crato.Recife, SUDENE, Sërie Geologia Regional, $\underline{3}, 35 \mathrm{pp}$.

CALDASSO,A.L. - 1968 - Geologia da quadrícula E-088, folha São João do Cariri,PB - Recife, SUDENE, Série Geologia Regiona1, 10:56 pp. i1.

CALDASSO,A.L. et al: - 1973 - Projeto SUDESTE PIAUI I, relatōrio fí nal integrado - Recife, DNPM/CPRM, $75 \mathrm{pp.} \mathrm{(circulação} \mathrm{restrita).}$ CALDASSO,A.L.S.; COSTA,A.L. \& HORIKAWA,Y. - 1973' - projeto Sudeste Piaui II - folha São João do Piaui SC, 23-X-B, relatório final par cial - Recife, DNPM/CPRM, 1 volume, 112 pp. (circulação restrita). CALDASSO,A.L.S. \& HAMA,M. - 1980 - Posicionamento estratigräfico das rochas băsicas da Bacia do Parnaíba - XXX Cong. Bras.Geol., Recife, 1980. Anais, vo1. 2 , pp.567-581.

CALHEIROS,M.E.V.; SOARES,R.M.L. \& TORRES,A.G. - 1981 - Geologia da região de Palmeira dos Indios(AL) - X Simp.Geol.do Nordeste da SBG, Recife, 1981. Atas, pp.306-314.

CAMPOS,M. et al. - 1976 - Projeto Rio Jaguaribe; relatörio finalRecife, DNPM/CPRM, 14 volumes (circulação restrita).

CAMPOS,M. et al. - 1979 - Projeto Rio Jaguaribe; relatörio final de geologia - Brasília, DNPM, Série Geologia, 4, Secção Geologia Bäsica, $1,149 \mathrm{pp}$.

CAROZZI,A.V. et al. - 1975 - Análise ambiental e evolução tectônica e sinsedimentar da secção Siluro-Eocarbonifera da bacia do Maranhão - Rio de Janeiro, CENPES/PETROBRÁS, Ciência-Técnica-Petróleo. Secção Exploração de Petróleo Publ. Z, 48 pp.

CHAPPEL, B.W. \& WHITE,A.J.R. - 1974 - Two contrasting granite types Pacific Geology,8:173-174, Tokio. 
CLOOS,H. - 1948 - The Ancient European basement blocks - Transactions, AGI, 29 (1): 99-103, Washington.

COBRA,R.Q. - 1963 - A série Jaibaras - Bol. do Nücleo de Pernambuco da Soc.Bras.Geo1., $1(1): 13-21$, Recife.

COBRA,R.Q. - 1963 - Estudo da estratigrafia, tectônica, ocorrências minerais e recursos d'água do noroeste do Ceará - Recife, SUDENE, D.G./DRN (inëdito).

COBRA,R.Q. - 1966 - Orientação dos seixos de quartzo do milonito da Serra das Russas - Recife, Bol.Rec.Nat.SUDENE, 4 (1/1):45-51.

COMDEPI- 1982 - Mapa geológico integrado projeto cobre-Mandacaruescala 1/20.000 - Terezina, Comp. Desenv.Piaui/CPRM, (inëdito). CORDANI,U.G. - 1978 - Comentários filosóficos sobre a evolução geológica pré-cambriana - Salvador, Nücleo Bahia da SBG, Publ. Esp. 3, pp. 33-41.

COSTA,A.C.da \& HORIKAWA,Y. - 1975 - Projeto Currais Novos, relatörio final - Recife, CNEN, CPRM, 1975, 2 volumes il. (circulação restrita).

COSTA,A.C.da; PEDROSA,I.L. \& MENDES,V.A. - 1977 - Projeto Agreste de Pernambuco, relatörio final - Recife, DNPM/CPRM, 3 volumes (circulação restrita).

COSTA,A.C.; MENDES,V.A.; ROCHA,D.E.G.A. \& ANDRADE,D.A. - 1978 - Pro jeto Extremo Nordeste do Brasil, relatório final - Recife,DNPM/ /CPRM, vol.1 (circulação restrita).

CoSTA,M.J. - 1980 - Rock and soil geochemical investigations on sul phide-bearing precambrian metavolcanics at Aurora, Ceará, State, Northeast Brazil. Leicester, 1980. $129 \mathrm{pp}$. il., (Master Thesis). CoSTA,M.J. et al. - 1973 - projeto Jaibaras, relatōrio final - Recife, DNPM/CPRM, 5 volumes (circulação restrita).

COSTA,M.J. et al. - 1978 - Projeto Aprazíve1 - Recife, CPRM/Super. Reg.do Recife, $83 \mathrm{pp.} \mathrm{(circulação} \mathrm{restrita).}$ COSTA,M.J.; BACCHIEGA, I.F. \& LINS,C.A.C. - 1975 - O Eocambriano e Cambro Ordoviciano do Nordeste do Ceara (Grupos Bambui e Jaibaras - VII Simp.Geol.do Nordeste da SBG, Fortaleza, 1975. CPRM, $21 \mathrm{pp}$.

CRANDALL, R. - 1910 - Geographia, Geologia, Supprimento d'ägua,Transporte e Açudagem nos Estados Orientais do Nordeste do Brazil, Parahyba, Rio Grande do Norte e Cearā - Rio de Janeiro, IFOCS, Pub1. 4, Sërie I, D.E., $137 \mathrm{pp}$. 
CRANDALL,R. \& WILLIAMS,H. - 1910 - Mappa Geológico dos Estados do Ceará, Rio Grande do Norte e Parahyba 1/3.000.000 - Rio de Janeiro, IFOCS, Pub1.I, Sërie I,G.

CREPANI,E. et al. - 1977 - Mapa geológico preliminar do pré-cam briano do Piaui, escala 1/500.000 - VIII Simp. Geol. do Norde $\underline{s}$ te da SBG, Campina Grande - PB, 1977. Atas, pp.323-342.

CUNHA,F.M.B.da \& CARNEIRO,R.G. - 1972 - Interpretação fotogeológica do centro-oeste da Bacia do Maranhão - XXV Cong.Bras.Geol., Belém, SBG, 1972. Anais, pp.65-79.

DANTAS,J.R.A. - 1971 - Levantamento dos estudos geológicos do nordeste - Recife, DNPM/DGM, (Relatório, 1, 2 vol.), 194 pp. DANTAS,J.R.A. - 1974 - Carta geológica do Brasil ao milionésimo; fo tha Jaguaribe SB-24, folha Fortaleza SA-24, Brasil - Brasilia, DNPM, $95 \mathrm{pp}$.

DANTAS,J.R.A. - 1980 - Mapa geológico do Estado de Pernambuco, tex to explicativo - Recife, DNPM, Sërie Mapas e Cartas de Síntese, $1,112 \mathrm{pp}$.

DANTAS,J.R.A. et al. - 1970 - Reconhecimento geolögico da folha Re cife (SC-25-NO) - Recife, DNPM, 4 Distrito (inëdito).

DANTAS,J.R.A. et al. - 1970 - Reconhecimento geológico da quadrícu 1 a de Garanguns - Recife, DNPM, $4^{\circ}$ Distrito (inédito). DANTAS,J.R.A. \& CAULA,J.A.L. - 1982 - Mapa geológico do Estado da Paraíba, escala 1/500.000, texto explicativo - Campina Grande, $\mathrm{PB}, \mathrm{CDRM} / \mathrm{PB}, 133 \mathrm{pp}$.

DAVIES,F.B. \& WINDLEY,B.F. - 1976 - Significance of major proterozoic high grade linear belts in continental evolution - Nature, $\underline{263}$ (5576): 383-385, Basingstoke Hants.

DAVINO,A. - 1980 - Delineamento dos limites e estruturas do craton do Paramirim por gravimetria - XXXI Cong.Bras.Geol., Cambariú, 1980. Anais, vol.5, pp.2573-2582.

DEWEY,J.F. \& BIRD,J.M. - 1970 - Mountain belts and the new global tectonics - Journal of Geophysical Research, 75 (14): 2625-2647, Virginia.

DEWEY,J.F. \& BIRD,J.M. - 1970b - Plate Tectonics and GeosynclinesTectonophysics, $\underline{10}(5 / 6): 625-638$, Amsterdam. 
DICKINSON,W.R. - 1970 - Plate Tectonics Models of Geosynclines

Earth and Plan.Sci.Letters, 10(1):165-174, Amsterdan.

EBERT,H. - 1955 - Pesquisas no poligono das secas. In: Departamento Nacional da Produção Mineral, relatörio da diretoria, 1954. Rio de Janeiro, DNPM, pp.79-85.

EBERT,H. - 1962 - Baustil und regional metamorphose in präkambrischen grundgelurge brasiliens - Tschermaks Mim.U.Letr.Mitt, 8 (1): 49-81, Viena.

EBERT,H. - 1964 - Tectônica e metamorfismo regional do escudo brasileiro - Recife, SUDENE/DIV.GEOL., 49 pp. (circulação interna). EBERT,H. - 1966 - A subdivisão estratigräfica e tectônica do précambriano no Rio Grande do Norte e Paraiba - Rev.Eng.Miner. Me ta1., 43 (253):38-38, Rio de Janeiro.

EBERT,H. - 1967 - Observações sobre a subdivisão estratigräfica e a idade do pré-zambriano no nordeste brasileiro - Rev.Eng.Miner. Meta1., $\quad$ 46 (273):111-112, Rio de Janeiro.

EBERT,H. - 1969 - Geologia do alto Seridö. Nota explicativa e foTha geológica de Currais Novos - Recife, SUDENE, Sërie Geologia Regiona1, $11,120 \mathrm{pp}$.

EBERT,H. - 1970 - The pre-cambrian geology of the "Borborema" belt (States of Paraíba and Rio Grande do Norte, northeaster Brazil) and the origin of its mineralnresources - Geol.Rundschau, $\quad 59$ (3):1299-1326, Sttutgart.

ENNES,E.R.; GRAZIA,C.A. \& CALDASSO,A.L.S. - 1973 - Projeto Sudeste do Piaui I, relatōrio final - Recife, DNPM/CPRM, 3 volumes (ci culação restrita).

ESTADO DO CEARA/CPRM - 1972 - Mapa geológico preliminar do Estado do Cearä, escala 1/500.000 - Fortaleza. (Convênio Governo do E tado-CPRM).

ESTRELLA,G.0. - 1972 - o estägio "rift" nas bacias marginais do leste brasileiro - XXVI Gong.Bras.Geol.,Belem,PA, 1972. Anais, vol. 3 , pp. 29-34.

FARINA,M. - 1966 - Asbesto de Alagôas: relações litolögicas, estru turais e genéticas; Importância econômica - Recife, SUDENE, Série Especial, $\underline{3}, 67 \mathrm{pp}$.

FARINA,M. - 1969 - Ultrabasitos niqueliferos de Catingueira, Parai ba - Recife, SUDENE, Série Econômica 7, $76 \mathrm{pp}$. 
FARINA,M. - 1970 - Geologia da parte norte das quadrículas de Bata Tha e Arapiraca, Alagoas - Recife, SUDENE-DG/DRN, 71 pp. (circu lação interna).

FARINA,M. - 1977 - Perspectivas metalogenéticas de alguns granitos pös-orogênicos do nordeste brasileiro - VIII Simp.Geol.do Nordeste da SBG, Campina Grande, 1977. Atas, pp.121-129.

FARINA,M. - 1980 - Mineralização cupro-argento-aurífera de São Julião, Piaui. Caracterização geolögica preliminar do primeiro "Porphiry Copper" do Brasil - Recife, CPRM, 19 pp. (circulação restrita).

FERREIRA,J.A.M - 1967 - Considerações sobre uma nova estratigrafia do Seridó - Rev.Eng.Miner. Meta1., 45(265): 25-28, Rio de Janeiro.

FERREIRA,J.A.M. \& ALBUQUERQUE,J.P.T. - 1969 - Sinopse da geologia da folha Seridö - Recife, SUDENE, Sërie Geologia Regional, 18. $52 \mathrm{pp}$.

GAMA JUNIOR,E. - 1970 - Modelo geolögico das bacias do Recôncavo e Tucano - XXIV Cong.Bras.Geol., Brasilia, 1970. Anais,pp.191-200. GHIGNONE, J.I. - 1972 - Ensaio de paleogeologia do nordeste e as sequências sedimentares - XXVI Cong.Bras.Geol., Be1ēm,PA, 1972. Anais, vol. 3 , pp. 21-28.

GHIGNONE, J.I. - 1979 - Geologia dos sedimentos fanerozóicos do Estado da Bahia - Geol.e Rec.Min. da Bahia; Textos bäsicos, SME/ CPM, 1: 23-117, Salvador.

GRANT,N.K. - 1978 - Structural distinction between a metassedimentary cover an underlying basement in the $600 \mathrm{~m} . \mathrm{y}$. old Pan African domain at Northwestern Nigeria, West Africa-Bu11.Geo1.Soc. Am., 89 (1):50-58, Colorado.

HADDAD,R.C. \& LEONARDOS JUNIOR,D.N. - 1980 - Granitos anelares de Ta peruaba (Cearā) e processos metassomāticos associados - XXXI Cong.Bras.Geol., Balneário de Camboriú, 1980. Anais, vol. 5 , pp. $2626-2633$.

HASUI, Y.; ALMEIDA, F.F.M.de \& BRITO NEVES, B.B.de - 1978 - As estruturas brasilianas - XXX Cong.Bras.Geol., Recife, 1978. Anais, vol. 6, pp. 2423-2437.

HEDBERG,H. - 1972 - Summary of an International Guide to Stratigra phic Classification - Terminology and USAGE. (ISSC). Lethaia, $\underline{5}$ : 297-323, Os1o. 
HEDBERG,H. - 1976 - International Stratigraphia Guide. A guide to stratigraphic classification, terminology and procedure - New York, John Wiley \& Sons, $200 \mathrm{pp}$.

HILLS,E.S. - 1963 - Elements of structural geology - New York,John Wiley \& Sons, Inc., $483 \mathrm{pp}$.

HUMPHREY,F.L. \& ALLARD,G.0. - 1969 - Geologia da ärea do domo Itabaiana-Sergipe - Rio de Janeiro, CENPES, PETROBRÁS, $160 \mathrm{pp}$.

HURLEY,P.M. et al. - 1967 - Test of continental drift by compari sion of radiometric ages - R. Science, 157(3788): 495-500, Washington.

INDA,H.A.V. \& BARBOSA,J.F - 1978 - Texto explicativo para o mapa geológico do Estado da Bahia, escala 1:1.000.000 - Salvador, SME/CPM, 122 pp.i1.

INTEGRAÇAO dos mapas geológicos da bacia costeira Pernambuco-Paraí ba - 1967 - Recife, relatórios de graduação de 1966 e 1967 (circulação restrita). Elaborado a partir do Curso de Geologia Recife/UFPE.

JARDIM DE SA,E,F. - 1978a - Revisão preliminar sobre a "Faixa Dobrada do Seridó" e eventuais correlatas no nordeste - Rev.Ciência, UFRN, $1(1): 77-83$, Natal.

JARDIM DE SA,E.F. - 1978b - Evolução Tectônica da Região de Seridó: síntese preliminar, problemas e implicações - I Ciclo de Es tudos sobre Prospecção de scheelita no Nordeste, Currais Novos, $14 \mathrm{pp}$. (inëdito).

JARDIM DE SA,E.F. et a1. - 1979 - Observações sobre a estratigrafia e sequências ígneas da Bacia de Jaibaras, Noroeste do Ceará - IX Simp.Geo1.do Nordeste da SBG, Nata1, 1979. Anais,pp.30-38. JARDIM DE SA,E.F. et a1. - 1981 - Esboço da geologia pré-cambriana do Extremo Oeste Potiguar - X Simp.Geol.do Nordeste da SBG, Recife, 1981. Atas, pp.315-328.

JARDIM DE SÁ,E.F. \& FOWLER,F.H. - 1981 - A Orogênese Brasiliana e suas relações com faixas supracrustais do sudoeste do Ceará X Simp.Geo1.do Nordeste da SBG, Recife,1981.Atas,pp.337-350. JARDIM DE SA,E.F. \& HACKSPACHER,P.C. - 1980 - Reconhecimento estru tural na borda noroeste do Craton São Francisco - XXXI Cong.Bras. Geo1., Camboriü, 1980.. Anais, vo1.5, pp.2719-2731. 
JARDIM DE SA,E.F.; LEGRAND,J.M. \& HACKSPACHER,P.C. - 1981 - Contras te de estilos estruturais e metamórficos na faixa dobrada Sergi pana - Rev.Bras.Geoc.,11(2):128-137, São Paulo.

JARDIM DE SA,E.F.; LEGRAND,J.M. \& MCREATH, I. - 1981 - Estratigrafia das rochas granitóides na região do Seridó (RN-PB), com base em critërios estruturais - Rev.Bras.Geoc.,11(1): 50-57, São Paulo.

JARDIM DE SÁ,E.F. ॄ SALIM,J. - 1980 - Reavaliação dos conceitos es tratigräficos na região do Seridö(RN-PB) - Rev.Eng.Miner. Meta1.,44 (421):16-28, Rio de Janeiro.

JORDAN,H. - 1971 - The late Precambrian synclinorium of Curaça(Bra zil) - Geo1.Jahrb. 88:617-628, Hannover.

JORDAN,H. - 1973 - Grupo Minas no Nordeste da Bahia, Brasi1-XXVII Cong. Bras.Geo1. Aracaju, 1973, vo1.2, pp.79-99.

KEGEL, W. - 1956 - As inconformidades na Bacia do Parnaíba e zona ad jacentes - Bol.DGM/DNPM, (160):60 pp. Rio de Janeiro.

KEGEL,W. - 1961 - Os lineamentos na estrutura geólögica do nordeste

- An.Acad.Bras.Cienc. 33: 25-26, Rio de Janeiro.

KEGEL,W. - 1965 - A estrutura geolögica do nordeste do Brasil - Bol. DNPM,Div.Geo1.Min., (227): pp.1-52; Rio de Janeiro.

KEGEL,W. \& BARROSO,J.A. - 1965 - Contribuição a geologia do médio São Francisco na região de Juazeiro, Brasil - Bol.DNPM,Div. Geol. Min., (225):1-24, Rio de Janeiro.

KEGEL,W. \& BARROSO,J.A. - 1966 - Contribuição a geologia do submēdio e baixo São Francisco - Bol.DGM/DNPM, (231):p.42, Rio de Janeiro.

KEGEL,W.; SCORZA,E.P. \& COELHO,F.C.P. - 1958 - Estudos geológicos no norte do Ceará - Bol.DNPM,Div.Geo1.Min. (184):1-52, Rio de Janeiro.

KHAIN, V.Ye \& SHEYNMANN, YU M. - 1962 - Hundredth anniversary of the geosynclinal theory - Int.Geo1.Rev.,4 (2):166-197, Washington. KORPERSHOER, H.R.; MENDONÇA,J.A.J.de \& TORQUATO,J.R.F. - 1979 - A geologia da região de Pedra Verde, Cearä - IX Simp.Geol.do Nor deste da SBG., Nata1, 1979. Atas, pp.349-363.

KREMER,G. \& GOMES,P. - 1967 - Sugestões para padronização de con venções geológicas no Brasil - $2^{a}$ ed.,Recife,CONESP/SUDENE, $2 \overline{9}$ pp. 
KRÓNER,A. - 1977 - Precambrian Mobile Belts of Southern e Eastern Africa - ancient sutures or sites of ensialic mobility? A case for crustal evolution towards plate tectonics - Tectonophysics, 40 $(1 / 2), 101-135$, Amsterdam.

KRÖNER,A. - 1980a - Panafrican crustal evolution - Episodes, 1980, (2):3-8, Ottawa.

KRÖNER,A. - 1980b - Principles and Problems of Correlation in Precambrian Mobile Belts. In: "IUGS/UNESCo" Principles and Crite ria of Subdivision of Precambrian in Mobile Zones - Lenigrado, pp. $54-77$.

LEITE,W.A. - 1969 - Geologia do Baixo São Francisco e depósitos de Asbestos de Alagoas - Recife, SUDENE,DG/DRN, $77 \mathrm{pp}$. (inédito). LEITE,W.A. - 1977 -Geologia e depösito de asbesto do baixo São Francisco - Recife, DRM/DRN/SUDENE, Sërie Geologia Regional, 21, $180 \mathrm{pp}$.

LENZ,R. - 1972 - Die Serie Bambui in Bereich des Pernambuco - Li neamentes - Geo1.Jb.B.2: 39-54, Hannover.

LE PICHON,X.; FRANCHETEAU,J. \& BONNIN,J. - 1973 - Plate Tectonics Amsterdam, Elsevier, $300 \mathrm{pp}$. (Development in geotectonics). LIMA,E.de A.M. et al. - 1980 - Projeto Scheelita do Seridö, relatörio final - Recife, DNPM,CPRM, vols.1-5,8, 1284 pp.i1.(circulação restrita).

LIMA,M.R. - 1978 - Microfösseis da Formação Exü, Cretäceo do Nordeste do Brasil - XXX Cong.Bras.Geo1., Recife,1978. Anais, vol. $\underline{2}$, pp. 186-187.

MABESOONE,J.M. \& CAMPANHA,V.A. - 1974 - Sinöpse de estratigrafia das sequências sedimentares do Nordeste Brasileiro - Bol.Núcleo Nord. SBG (2):7-22, Recife.

MABESOONE,J.M. \& CAMPANHA,V.A. - 1974 - Caracterização estratigräfica dos Grupos Rio do Peixe e Iguatü - Estudos Sediment. 314: 22-41, Natal.

MABESOONE,J.M.; BEURLEN, K. ॄ RAND,H.M. - 1971 - Geologia da Bacia de Jaibaras (Cearä) - Estudos Pesq.,2, 115 pp. Sépie B, Inst. Geoc.UPPE, Recife.

MABESOONE, J.M.; CAMPO E SILVA,A. \& BEURLEN,K. - 1972 - Estratigrafia e origem do Grupo Barreiras em Pernambuco, Paraíba e Rio Gran de do Norte - Rev.Bras.Geoc.,2(3):173-188, São Paulo. 
MAPA Geológico integrado da região de Itabaiana e Pilar,PB, escala 1/50.000-1976 - Recife, Disciplina Geologia de Campo I, (inëdito). Elaborado a partir do Curso de Geologia, Recife/UFPE. MAPA Geológico integrado da região de Limoeiro e Carpina,PE,escala 1/50.000 - 1978 - Recife, Disciplina Geologia de Campo I, (inêdi to). Elaborado a partir do Curso de Geologia, Recife/UFPE. MAPA Geológico do Município de Timbauba, PE, escala 1/50.000 -1978Recife, Disciplina Geologia de Campo IV, (inëdito). Elaborado a partir do Curso de Geologia, Recife/UFPE. MAPA Geológico integrado da região de Aliança e Itaquitinga, PE, escala 1/50.000 - 1979 - Recife, Disciplia Geologia de Campo I, (inëdito).Elaborado a partir do Curso de Geologia, Recife/UFPE. MAPA Geológico integrado de ārea a NW de Surubim, escala 1/30.0001980 - Recife, Disciplina Geologia de Campo I, (inëdito). Elabo rado a partir do Curso de Geologia, Recife/UFPE.

MARANHAO,R.J.L. ¿ SIQUEIRA,L.P. - 1977 - A Geossinclinal do Seridó - Bo1.Minera1., 5:51-94, Recife.

MARMO,V. - 1971 - Granite Petrology and the Granite Problem - Amsterdam, E1sevier Pub1.Co., Developments in petrology $\underline{2}, 244 \mathrm{pp}$. MASCARENHAS, J.F. - 1973 - A Geologia do Centro Leste do Estado da Bahia - XXVII Congr.Bras.Geol., Aracaju,1973. Anais, vol. 2 ,pp.3566.

MASCARENHAS;J.F. - 1979 - Evolução geotectônica do precambriano do Estado da Bahia. In: "Geologia e recursos minerais da Bahia, Tex tos básicos" - vol. $\underline{2}$, Salvador, pp. 55-165.

MC CURRY,P. - 1971 - Pan African Orogeny in Northern Nigeria - Bull. Geol.Soc.Am., 82 (11):3251-3262, Colorado.

Mc REATH, I. - 1977 - Datação de rochas metamörficas - VII Simp. Geo1.do Nordeste da SBG, Campina Grande, 1977, p. 47,(Bo1. Esp. Resumo das Com.).

MC REATH,I. \& JARDIM DE SA,,E.J. - 1979 - Datações geocronolögicas em rochas policíclicas: interpretação alternativa para os dados no Seridó (RN-PB) - IX Simp.Geol.do Nordeste da SBG, Natal,1979. Atas, vol. I,pp.84-89.

MELLO,A.A.de - 1979 - Características Geológicas e Metalotectônicas dos Cinturões Möveis do Nordeste Oriental - Recife, CPRM, $82 \mathrm{pp}$. Circulação restrita (Palestra apresentada na IV Semana de Geologia do Recife). 
MEllo,A.A.et a1. - 1977 - Contribuição à geotectônica da Região Nordeste do Brasil - Recife, Boletim Mineralógico, 5, 25-40. MELLO,A.A. e MELLO,Z.F. - 1974 - Metamorphic zoning in the Serido region, northeastern Brazi1 - Rev.Bras.Geoc.,4(1):1-14, São Paulo. MELLO,A.A.de \& SIQUEIRA,L.P. - 1971 - Novas considerações sobre

a geologia do prë-cambriano de Pernambuco Oriental - Rev. Trim. da A.G.P., I (2):32-41, Recife.

MELLO,A.A.de; SOUZA,E.M. \& MENDONÇA,J.C.G - 1978 - A tectônica 1inear no estado do Cearä - XXX Cong.Bras.Geol., Recife, 1978 Anais, vol.1, pp.393-407.

MELLO,Z.F. - 1977 - Considerações tectono-petrolögicas em sequências molässicas do Nordeste Oriental do Brasil - Recife, UFPE, 254 pp. (Dissertação de Mestrado apresentada ao Centro Tecnol. da UFPE).

MELLO,Z.F. - 1978 - Evoluções finais do Ciclo Brasiliano no Nordeste Oriental - XXX Cong.Bras.Geol., Recife, 1978. Anais, vol.6,pp. 2438-2450.

MELO,U.de - 1982 - Os folhelhos pretos cretäceos do Atlantico sulcentral e sua importância petroliffera - II Cong.Bras.Petrol., Rio de Janeiro, 1982, 21 pp.(prë-print).

MENDES,N. \& SOUTO,P.G. - 1966 - Mapa geolögico 1:50.000 da ārea de Canudos - II Simp.Geo1.do Nordeste da SBG, Recife, (inëdito). MENDONÇA,J.C.G.; BRAGA,A.P.G. \& CAMPOS,M. - 1980 - Considerações so bre a mineralização fósforo uranífera da jazida de Itataia, $C E$. XXXI Cong.Bras.Geo1.,Camboriü, 1980. Anais, vo1.4,pp. 2472-2486. MENDONÇA,J.C.G.; CAMPOS,M.; BRAGA,A.P.G. \& SOUZA,E.M. - 1982 - Caracterização estratigräfica dos metassedimentos da região de Ita taia,CE (Grupo Itataia) - XXXII Cong.Bras.Geo1.,Salvador, 1982. Anais, vol.1, pp.325-338.

MISSAO GEOLOGICA ALEMA - 1973 - Mapa Geolögico da Região de Curaçá -Uauá 1/250.000 - Recife,DRN/Divisão Geologia, SUDENE.Pub1.Esp. MITCHELL,A.H.G. \& READING,H.G. - 1969 - Continental Margins, Geosynclines and Ocean Floor Spreading - J.Geol.,77(6):629-646, II 1 inois.

MOODY,J.M. \& HILL,M.J. - 1956 - Wrench Fault Tectonics - Bul1.Geol. Soc.Am., $67(9): 1207-1246$, Boulder. 
MOORBATH,S. - 1975 a - Evolution of precambrian crust from Strontium isotopic evidence - Nature, 254(5499):395-398, Basingstoke Hants. MOORBATH,S. - 1975b - Geochronological interpretation of whole-rock isochron dates from high grade gneiss terrains. Nature, (5507):391, Basingstoke Hants.

MOORES,E.M. - 1981 - Ancient suture zones within continents - Scien ce, $\underline{213}(4503): 41-46$, Washington.

MORAES,L.J. \& ALVES,B.P. - 1952 - Geologia e Recursos Minerais do re tangulo Paulo Afonso. In: Estudos da zona de influência da cachoeira de Paulo Afonso - Rio de Janeiro, Brasil/IBGE,pp.107-196. MORAES,L.J.; BARBOSA,R.A. E SCORZA,E.P. - 1969 - Estudo geológico da região da barragem de Sobradinho, Estado da Bahia - Bol.DNPM/ Div.Geo1.Min., (229):1-61, Rio de Janeiro.

MOTTA,A.C. et al. - 1979 - Feições gravimētricas e magnetométricas do Craton do São Francisco - I Simp.Geol.do Craton do São Fran cisco e suas faixas marginais - Salvador,1979. p. 26,(Resumos). MOTTA,A.C. ६ GOMES,R.A.A.D. - 1982 - Compartimentiação tectônica da Bacia Potiguar interpretada a partir de mapa Bouguer - XXXII Cong. Bras.Geo1., Salvador, 1982. Anais, vol.4 pp.1644-1651. MUNIS,M.B. - 1971 - Quantificação dos depösitos de gipsita do Arar $\underline{\mathbf{i}}$ pe (Ârea de Casa de Pedra) - Recife, SUDENE/DG, Série Geologia Econômica, $41 \mathrm{pp}$.

MUNIS,M.B. \& SANTOS,E.J. dos - 1980 - Prospecto cobre, chumbo e zin co na Faixa Cachoeirinha-Salgueiro, relatório tëcnico-científico - Recife, CPRM, 51 pp.il.(circulação restrita). MURATOV's.V.V. - 1972 - Main structural elements of the crust on continents, their interrelations and age. In: XXIV Int.Geol. Cong., Montrea1, 1972. Section 3, pp.71-78. NASCIMENTO,D.A. e GAVA,A. - 1979 - Novas considerações sobre a estratigrafia da Bacia Jaibaras - IX Simp.Geol.do Nordeste da SBG,
Natal, RN, 1979. Atas, pp.14-26. NETTO,A.S.T. - 1978 - "Mesozóico-Paleozóico". In: INDA,H.A.V.\& BARBOSA, J. - Mapa Geológico do Estado da Bahia, escala 1:1.000.000, texto explicativo - Salvador, pp.59-70. NOVAIS,F.R.G.; BRITO NEVES,B.B. ६ KAWASHITA, K. - 1979 - Reconhecimen to Cronoestratigräfico na região noroeste do Cearä - IX Simp. Geo1.do Nordeste da SBG, Nata1,1979. Atas, pp.93-110. 
OJEDA,H.A. \& FUGITA,A.M. - 1974 - Bacia.Sergipe-Alagoas: geologia regional e perspectivas petroliferas - XXVIII Cong.Bras.Geo1., Porto Alegre, 1974. Anais, vo1.1, pp.137-158.

OLIVEIRA,J.C. et al. - 1974 - Projeto Cococi; relatörio final integrado - Recife, DNPM/CPRM, 5 volumes (circulação restrita).

PAIVA,G. - 1945 - Evolução dos conhecimentos sobre a geologia crip tozóica do nordeste do Brasil - Rio de Janeiro, DNPM/DFPM, Bol. 73, pp.13-31.

PEDREIRA,A.J.; KISHIDA,A .; TORQUATO,J.R.F. \& MASCARENHAS,J.F. 1978 Inventärio e reavaliação do conhecimento geológico da parte cen tral do Craton do São Francisco. In: Reunião preparatôria para - Simp.do Craton do São Francisco e suas faixas marginais. Anais. Salvador, SME/CPM-BA/SBG, Pub1.Esp. $\underline{3}$, pp.67-136.

PEIVE,A.V. - 1960 - Fractures and their role in the structure and development of the earth's crust. In: XXI Cong.Geol.Int., Copenhagen, 1960 - Proceedings, Part 18, pp.280-286.

PESSOA,D.A.R. - 1976 - Estudo geocronológico das rochas policîclicas do Complexo São Vicente nos anticlinórios de Caicó e Flora nia, RN - São Paulo, Inst.Geoc.USP, 53 pp. inēdito: (Dissertação de Mestrado, Inst.Geoc.da USP).

PETROBRĀS/DNPM - 1975 - Cartas geolögicas da bacia Sergipe- Alagoas, escala $1 / 50.000$ - Rio de Janeiro, Petrobräs/DNPM org.MME. PETROBRĀS/RENOR - 1969 - Mapa geológico geral da Bacia do Maranhão - escala 1/1.000.000 - Comp1.por S.Nahass e G.Aguiar - Rio de Janeiro (cōpia heliogräfica) .

PETROBRĀS/RPBA - 1965 - Mapa geológico das bacias Recôncavo-AlmadaTucano-Jatobä, escala 1/500.000 - Salvador, RPBA/PETROBRĀS. PONTE,F.C.et a1. - 1971 - Evolução Paleogeolögica do Brasil Oriental e Africa Ocidental - Salvador, SETUP/BA/PETROBRĀS, CPEG IV, Relat.Tec.7, 2 volumes.

PORTO,R. ¿ SZATMARI,P. - 1982 - Classificação Tectônica das Bacias

Sedimentares Terrestres do Brasil. In: XLV RANE/ARPEL, MëxicoME, 1982, 15 pp. (pré-print).

PRADO,F.S. et al. - 1979 - Projeto Martinópole; relatōrio final

- Recife, DNPM/CPRM, 9 volumes (circulação restrita).

PRIEM,H.N.A. et al. - 1978 - K-Ar Dating of a basaltic layer in the Sedimentary Lavras Basin, Northeast Brazil - Rev.Bras.Geoc. 8 (4):262-269, São Paulo. 
RAND,H. - 1976 - Estudos geofísicos da faixa litorânea ao sul do Recife - Recife,UFPE, $112 \mathrm{pp}$. (Tese de Livre Docência apresenta da ao Centro de Tecnologia da UFPE).

RAND, H.; SIAL,A.N.; BRITO NEVES,B.B.de \& MANSO,V. - 1980 - Gravime tric and magnetometric study of the late precambrian Sergipe Folding System; Northeast Brazil - XXXI Cong.Bras.Geol., Camboriú, 1980. Anais, vol. $\underline{5}$, pp. 2700-2708.

REBOUÇAS,A.C.; MANOEL FILHO,J. \& BENOIT,H. - 1967 - Bacia Potiguar, estudo hidrogeológico - Recife, SUDENE, Sërie Hidrogeologia, 15, 2 volumes, $200 \mathrm{pp}$.

RICHTER,A.J. - 1967 - Geologia do "horst" que separa as bacias ecôncavo-Tucano e Alagoas-Sergipe - Colet.Relat.Exp1. PETROBRÃS/ DEPIN/CENPES, 2(4):169-177, Rio de Janeiro.

RICHTER,A.J. \& PONTE,F.C. - 1964 - Reconhecimento geológico da par te central e norte do "horst" que separa as bacias do Reconcâa vo-Tucano e Jatobả da Bacia Sergipe-Alagoas - Maceió, SERDESTE, PETROBRAS/Div.Reg.de Exp1., Relatörio 316 (inédito).

RIES,A.C. - 1977 - Stromatolites in the Cearä Group (precambrian) in Brazil - VIII Simp.Geol.do Nordeste da SBG, Campina Grande, 1977. Atas, pp.393-396.

RIES,A.C. \& SHACKLETON,R.M. - 1977 - Preliminary note on structural sequences and magnitude and orientation of finite strains in the precambrian of northeast Brazil - VIII Simp.Geol.do Nor deste da SBG, Campina Grande, 1977. Atas, pp.397-400.

ROCHA CAMPOS,A.C. \& BRITO NEVES,B.B.de - 1979 - Glaciação paleozöi ca no Brasil na latitude $10^{\circ} \mathrm{S}$ - IX Simp.Geol.do Nordeste da SBG, Natal,RN, 1979 - Res.Com. 51 pp.

ROSSITER,F.A.do M.; MÖLLER,J.C.; FROTA,W.D. ६ PETREL,J.F. - $1981-$ Projeto Cearâ, relatório final - Salvador, AUSTRAL/CARAIBA METAIS S/A, $110 \mathrm{pp.} \mathrm{(circulação} \mathrm{restrita).}$

SA,F.T. \& TINOCO SOBRINHO,J - 1979 - Estratigrafia da região sudes te de São Raimundo Nonato,PI e Norte de Remanso, BA - IX Simp. Geol.do Nordeste da SBG, Nata1,1979. Atas,pp.1-12.

SALOP,L.I. - 1972 - Two types of Precambrian structures: gneiss folded ovals and gneiss domes - Int.Geol.Rev.14(11):1209-1226, Washington. 
SANTOS,E.J.dos - 1968 - Contribuição ao estudo da geologia da quadrícula de Açu - Recife, SUDENE, Série Geologia Regiona1 6, 116 $p p$.

SANTOS,E.J.dos - 1969 - O modo de evolução de alguns migmatitos dos arredores de Belëm e Brejo da Cruz, Paraíba - Recife, SUDENE, SEe rie Especial, $8,40 \mathrm{pp}$.

SANTOS,E.J.dos - 1971 - As feições estruturais da folha Arcoverde, Pernambuco e o mecanismo dos falhamentos da "zona transversal"

- Rev.Eng.Miner.Meta1.,53(313):35-40, Rio de Janeiro.

SANTOS,E.J.dos - 1973 - Província scheelitifera do Nordeste - XXVII Cong.Bras.Geol., Aracajü,1973. Bo1.2. roteiro das excursões pp. 31-46.

SANTOS,E.J.dos - 1977 - O mode1o de evolução precambriana da região de Arcoverde, Pernambuco - VIII Simp.de Geol.do Nordeste da SBG, Campina Grande, 1977. Atas, pp.225-245.

SANTOS,E.J.dos - 1981 - Mapa geológico do Brasi1, escala 1/2.500.000, Região Nordeste; texto explicativo - Brasília, DNPM, 53 pp.il. (em impressão).

SANTOS,E.J.dos \& CALDASSO,A.L.S. - 1978 - Sintese dos conhecimentos e ensaio interpretativo da ärea do Riacho do Pontal, Nordes te do Brasil. In: Reunião preparatöria para o Simp.do Craton do São Francisco e suas faixas marginais - Anais, Salvador, SME/ CPM-BA, Pub1.Esp. 3 , pp.399-426.

SANTOS,E.J.dos \& MELO,O.B.M. - 1978 - Diversidade do plutonismo granitico brasiliano do Nordeste. In: XXX Cong.Bras.Geol., Reci fe, 1978. Anais, vo1.6:il. 2624-2634.

SANTOS,E.J.dos \& SILVA FILHO,M.A. - 1975 - Ensaio interpretativo sobre a evolução da geossinclinal de Propriá, Nordeste do Bra si1 - Rev.Miner.Meta1.,39(367):3-22, Rio de Janeiro.

SANTOS,E.J.dos \& VASCONCELO,M.J.S. - 1973 - Características dos granitöides de tipo Moderna do Iineamento Pernambuco -Rev.Miner.Metal., 36 (339):28-33, Rio de Janeiro.

SANTOS,J.P. - 1967 - Geologia da região ferrífera de São Josë do Belmonte - Recife, SUDENE, Sërie Geologia Econômica, 5, 45 pp. SCHOBBENHAUS FILHO,C. et al. - 1981 - Mapa Geológico do Brasil e da Area Oceânica Adjacente incluindo Depósitos Minerais - Escala $1 / 2.500 .000$ - Brasilia, MME/DNPM/DGM. 
SCHALLER,H. - 1969 - Revisão estratigräfica da Bacia Sergipe/Alagoas - Bo1.Tec. Petrobrás, 12(1):21-86, Rio de Janeiro.

SHACKLETON, R.M. - 1976 - Pan-African Structures - Phil.Trans.R.Soc. London, A-280:491-497, London.

SIAL,A.N. - 1976 - The Post-Paleozoic Volcanism of Northeast Brazil and its Tectonic Significance - Anais da Acad.Bras.Cienc., 48:299-312, Rio de Janeiro.

SIAL,A.N. \& LONG, L.E. - 1978 - Rb-Sr and oxigen isotope study of the Meruoca and Mocambo granites, northeastern Brazil - Aspen - Colorado, U.S.G.S.Open file Report 78-101,pp.398-400.

SIAL,A.N. \& MENOR,E.de A. - 1965 - Geologia da meia quadrícula sul de Taquaritinga do Norte - Inst.Geoc./UFPE, Série B. Estudos e Pesquisas, 1 (1):1-48, Recife.

SIAL,A.N.; FIGUEIREDO,M.C.H. \& LONG,L.E. - 1981 - Rare Earth Element Geochemistry of the Meruoca and Mucambo Plutons, Ceara Nor theast Brazil - Chemical Geology,1980, (31):271-283, Amsterdam.

SILVA FILHO,M.A.de - 1976 - A suite ofiolítica da geossinclinal de Propriá - XXIX Cong.Bras.Geol., Ouro Preto,MG, 1976. Anais, vol. 4, pp. $51-58$.

SILVA FILHO,M.A.de - 1980 - Prospecto cobre-chumbo-zinco("red beds" da Formação Estância) - Salvador, CPRM, $16 \mathrm{pp}$.(inëdito).

SILVA FILHO,M.A.de et al. - 1977 - Projeto Baixo São Francisco/Va za Barris, geologia da geossinclinal Sergipana e do seu embasamento - Relatório final, Salvador, DNPM/CPRM, 19 volumes (circu lação restrita).

SILVA FILHO,M.A.de et al. - 1981 - Projeto Complexo Canindé do São Francisco, Mapa geológico integrado $1 / 100.000=$ Salvador, CPRM/DNPM (inëdito).

SILVA FILHO,M.A.de; BONFIM,L.F.C. \& SANTOS,R.A.dos - 1978a - A geos sinclinal Sergipana: estratigrafia, estrutura e evolução - XXX Cong.Bras.Geol., Recife, 1978. Anais, vol. 6, pp.2464-2477.

SILVA FILHO,M.A.de \& BRITO NEVES,B.B.de - 1979 - O Sistema de Dobra mentos Sergipano no nordeste da Bahia. In: "Geologia e Recursos Minerais da Bahia, textos bäsicos - 1 vol., Salvador, SME/CPM, pp. 203-217.

SILVA FILHO,M.A.de; SANTANA,A.C. \& BONFIM,L.F.C. - 1978b - Evolução tectono-sedimentar do Grupo Estância:suas correlações - XXX Cong. Bras.Geol., Recife,1978.Anais,vo1.2, pp.685-699. 
SILVA,G.A.N.P. et al. - 1972 - Projeto Gilbuês, relatório final Recife, DNPM/CPRM, 3 volumes (circulação restrita).

SIQUEIRA,J.P. ¿ MARANHÃO,R.J.L. - 1971 - Novas considerações sobre

a geologia da região do Seridó - R.Ass.Geol.Pernambuco, 1 (1):4146 , Recife.

SIQUEIRA,L.S. ¿ MARANHÃO,R.J.L. - 1973 - O zoneamento e a estratigrafia da geossinclinal do Seridó - $20 \mathrm{pp}$. (Trabalho apresentado ao XXVII Cong.Bras.Geol., Aracaju) inédito.

SIQUEIRA FILHO,J. - 1967 - Geologia da folha de Jutaí, Pernambuco

- Recife, SUDENE, Série Geologia Regional,7, 58 pp.

SLOSS,L.L. - 1972 - Synchrony of Phanerozoic sedimentary tectonic events of the north America Craton and Russian platform - XXIV Int.Geo1.Cong., 1972, Section 6, pp.24-32.

SMALL,H. - 1913 - Geologia e supprimento de agua subterrânea no Ceará e parte do Piauhy - Rio de Janeiro, IFOCS, Pub1.25, sêrie I-D. $\left(2^{\mathrm{a}}\right.$ ed. $)$.

SMALL,H. - 1914 - Geologia e supprimento de agua subterrânea do Piauhy e parte do Ceará - Rio de Janeiro, IFoCS, Publ.32,sẻrie $I-D$.

SOARES,P.C.; LANDIM,P.M.B. \& FULFARO,V.J. - 1974 - Avaliação preliminar da evolução geotectônica das bacias intracratônicas bra sileiras - XXVIII Cong.Bras.Geo1.,Porto Alegre,RS, 1974. Anais, vol. $1, \mathrm{pp} .61-84$.

SÖFNER,B. - 1970 - Die Bambui Serie in Gebiet von Petrolina/Pernam buco und Juazeiro/Bahia, Brasilien - Geol.Jb., 88:611-616, Hannover.

SOFNER,B. - 1972 - Zur stratigraphie des prakambriuns im gebiet des mittleren rio São Francisco zwischen Sento Sé und Juazeiro, nordost Brasilien - Geol.Jb.12:95-146, Hannover (Beich 121), SOUZA,S.M. - 1982 - Atualização da litoestratigrafia da Bacia Poti guar - XXXII Cong.Bras.Geo1., Salvador, 1982. Anais, vo1. $\underline{5}$, pp. 2392-2406.

SOUZA,D.J .; FERNANDES FILHO,J.; GUIMARAES, J.T. \& LOPES, J.N.- 1979Projeto Colomí. relatörio final - Salvador, DNPM/CPRM, 3 volumes (circulação restrita).

STEPHANSON,O. - 1979 - Polydiapirism of Granitic Rocks in the Svecofennian of Central Sweden - Precambrian Research, 2 (2): 189214, Amsterdam. 
SUDENE/ASMIC - 1967 - Estudo geral de base do vale do Jaguaribe Recife, Hidrogeologia, GVJ.vol. 7, 246 pp.

SUDENE/DRN - 1966 - Símbolos e normas para mapas geológicos, pub1. esp. - Recife, SUDENE/DRN/DG, 18 pp. (circulação restrita). SUSZCZYNSKI,E.F. - 1966 - Considerações sobre a evolução tectonico -orogenética da parte oriental do escudo brasileiro - Bol. Rec. Nat. SUDENE 4 (3/4):371-416, Recife.

SUTTON,J. \& WATSON,J.V. - 1974 - Tectonic Evolution of Continents in ear1y Proterozoic Times - Nature 247:433-435. Basingstoke Hants .

TEIXEIRA,J.A.; DUARTE,E.W. \& BEZERRA,M.A. - 1967 - Informe hidrogeológico do extremo oeste de Pernambuco - Recife, CONESP/SUDE NE, Relat. $20,61 \mathrm{pp}$.

TEIXEIRA,W. - 1981 - Geocronologia das folhas Jaguaribe e Nata1, in: "Projeto Radambrasil, folhas SB.24/25 Jaguaribe/Natal:geologia, geomorfologia, pedologia, vegetação e uso potencial da terra" Rio de Janeiro, MME/Secretaria Gera1, 744 pp.

TESCH, N.A.; PEREIRA,L.H.M. ॄ CASE,,M.G. - 1980 - Mineralizações sul fetadas de cobre e níquel em rochas gabróides do complexo Canindé, Noroeste do Estado de Sergipe - XXXI Cong.Bras.Geo1., Camboriü, 1980. Anais, vol. $\underline{3}, \mathrm{pp} .1812-1826$.

TORRES,H.H.F. e ANDRADE,V.A. - 1975 - Projeto Jardim do Seridó, rela tório final - Recife, CNEN/CPRM, 2 volumes il.(circulação restri ta).

TROMPETTE, R. - 1970 - Les Dahomeyides em Bënin, Togo et Ghana: une chaine de collision d'âge pan-african - Rev.de Geol. Dynamique et de Geog.Physique, 21(5):339-349, Paris.

TUYEZOV,I.K. - 1967 - Transition Stages of Ancient Platforms in URSS - Int.Geo1.Rev. $\underline{9}(4): 584-597$, Washington.

VEIGA, P. - 1966 - Geologia da quadrícula Juazeiro do Norte, E-082 folha Crato,CE - Recife, SUDENE, Série Geologia Regiona1, 1,52 pp. VEIGA,P. - 1968 - Geologia da quadrícula Ouricuri, região do Arari pe, Pernambuco - Recife, SUDENE, Série Geologia Regional, 9, 56 pp. WHITE,A.J.R. \& CHAPPELL,B.W. - 1977 - U1trametamorphism and granitoid genesis - Tectonophysics, $43(1 / 2): 7-22$. Amsterdam. 
WINDLEY,B.F. - 1978 - The Evoluing Continents - Chichester, John Wiley \& Sons, $385 \mathrm{pp}$.

WINDLEY,B.F. \& BRIDGWATER,D. - 1971 - The evolution of archaean low and high grade terrains - Sidney, Spec.Pub1.Geol.Soc.Aust., $\underline{3}, \mathrm{pp}$. 33- 46 .

WINGE,W. -11967 - Breves notas sobre a geologia do noroeste do Cea rá - Recife, SUDENE, DG/DRN, Bol.Estudos, $\underline{3}, \mathrm{pp} .14-23$.

ZONENSHAYN,L.P. - 1967 - Tectonics of the folded regions of central Asia (the structural patterns of geosynclinal regions) - Geotec tonics, $1967(6): 356-365$, Washington. 


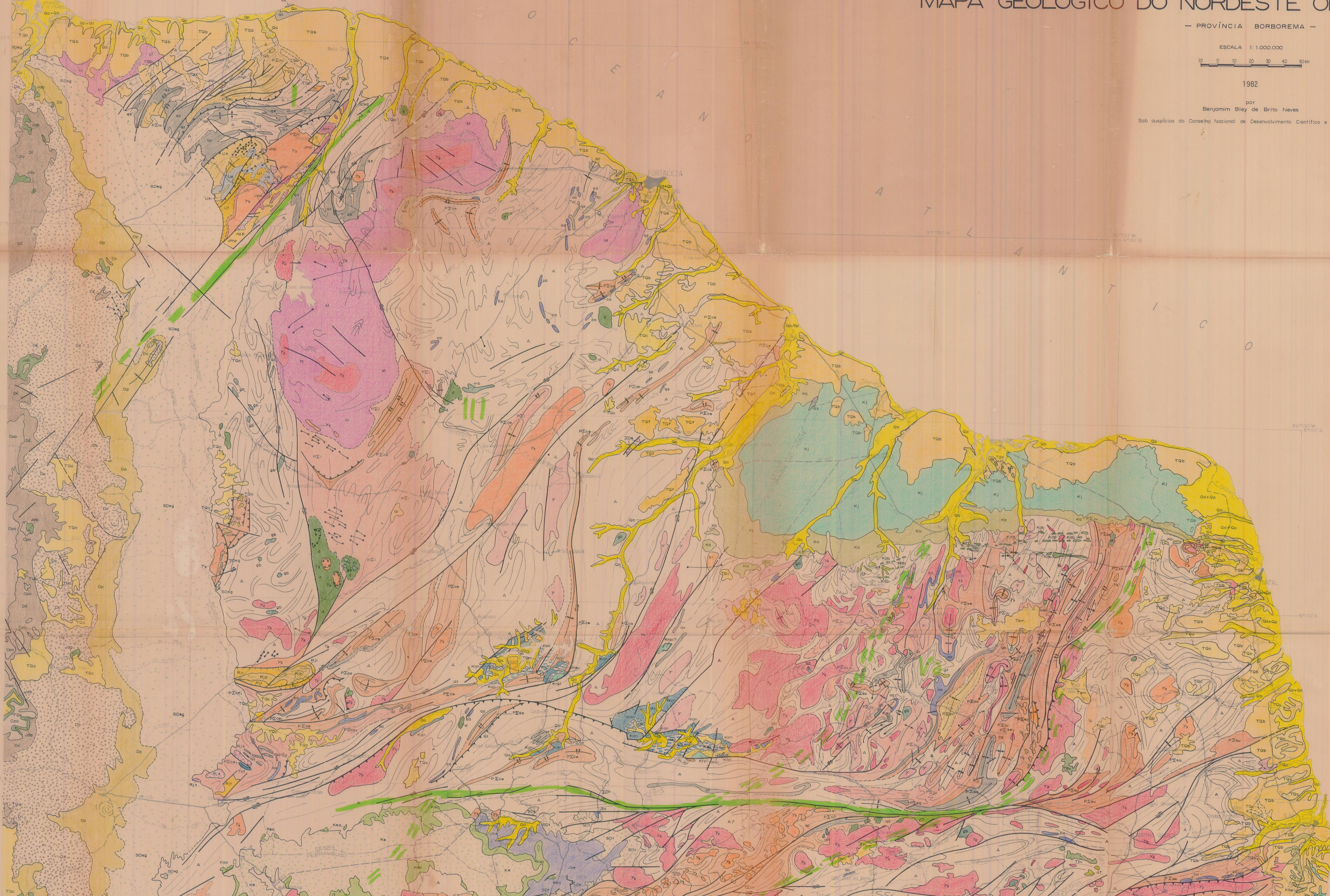

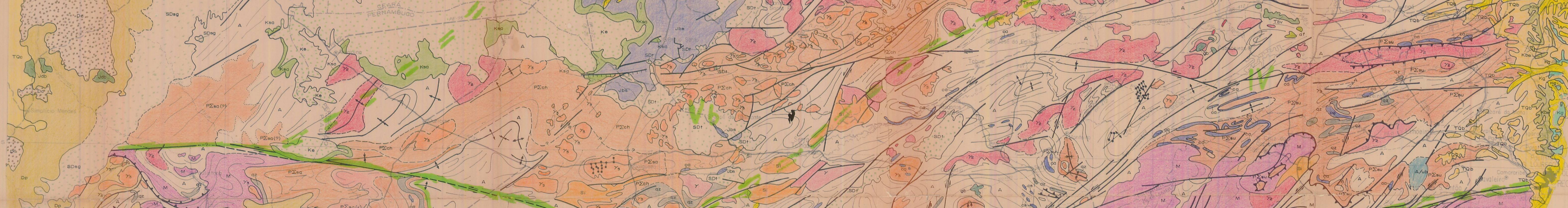

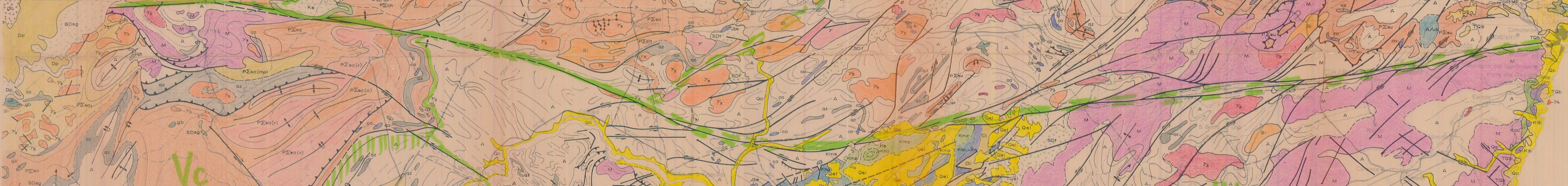
(1)

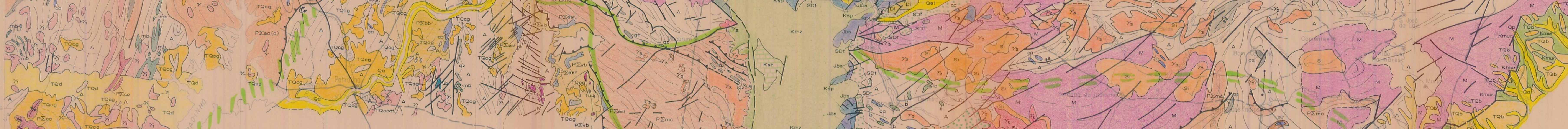
i. H.
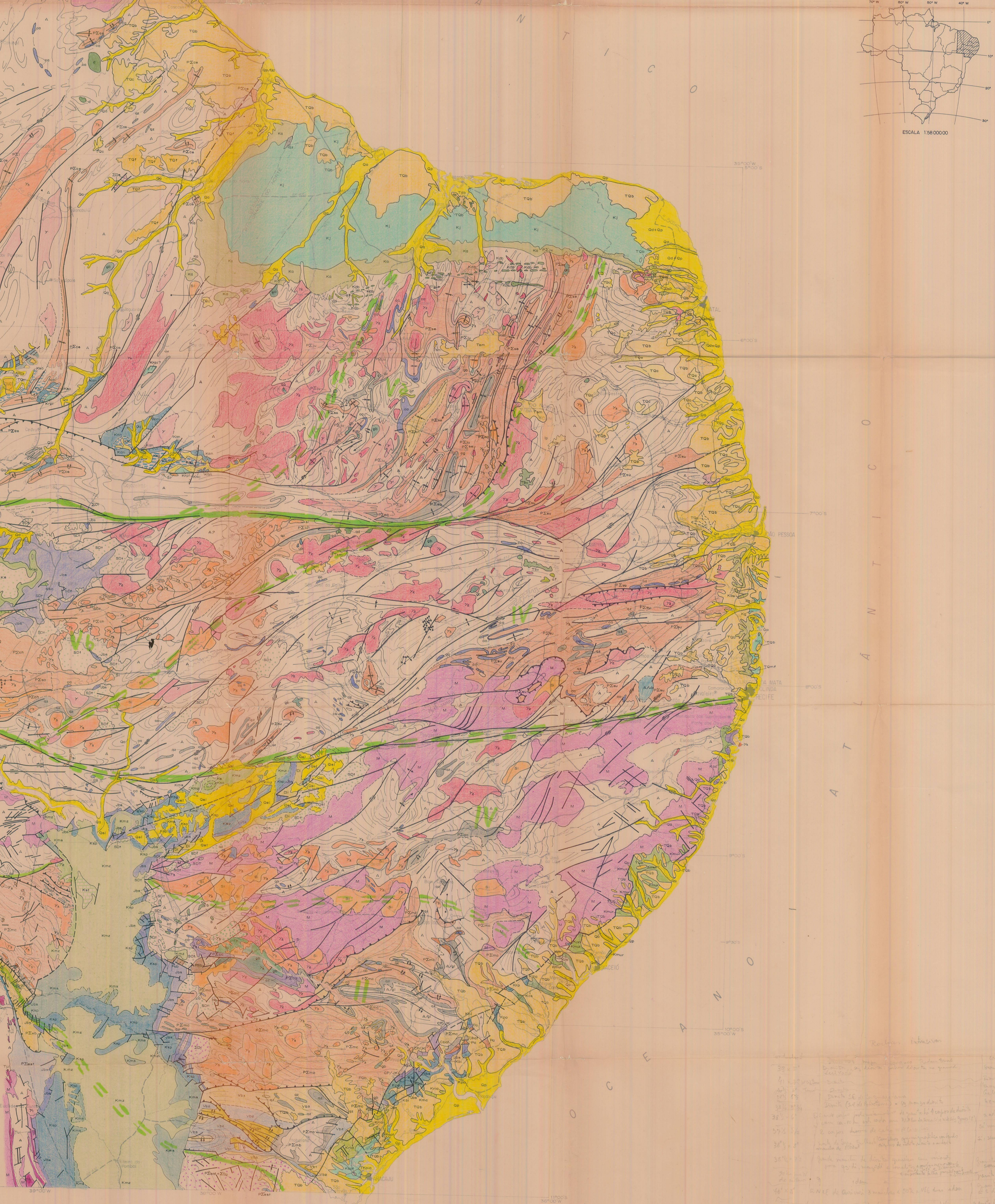